Report to the Test Director

\title{
EVALUATION OF VARIOUS TYPES OF PERSONNEL SHELTERS EXPOSED TO AN ATOMIC EXPLOSION
}

By

L. J. Vortman, Director, Program 34

Technical Associates

Harold Birnbaum and Edward Laing, Ammann \& Whitney

Frank G. Ort and Ralph V. Schumacher, Army Chemical Center

Approved by: ROBERT L. CORSBIE

Director, Civil Effects Test Group

Sandia Corporation

Albuquerque, New Mexico

Federal Civil Defense Administration

Battle Creek, Michigan

May 1956 


\section{DISCLAIMER}

This report was prepared as an account of work sponsored by an agency of the United States Government. Neither the United States Government nor any agency Thereof, nor any of their employees, makes any warranty, express or implied, or assumes any legal liability or responsibility for the accuracy, completeness, or usefulness of any information, apparatus, product, or process disclosed, or represents that its use would not infringe privately owned rights. Reference herein to any specific commercial product, process, or service by trade name, trademark, manufacturer, or otherwise does not necessarily constitute or imply its endorsement, recommendation, or favoring by the United States Government or any agency thereof. The views and opinions of authors expressed herein do not necessarily state or reflect those of the United States Government or any agency thereof. 


\section{DISCLAIMER}

Portions of this document may be illegible in electronic image products. Images are produced from the best available original document. 
2



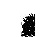

-

$-$

*

-

$-$

$-$

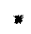




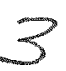

\section{ABSTRACT}

This joint Federal Civil Defense Administration-Atomic Energy Commission project was conducted to evaluate several shelter designs.

Two underground shelters (50-man capacity), one open and one closed, were exposed to the open shot, and two were exposed to an earlier shot (at $1050 \mathrm{ft}$ ). Three basement exit shelters were exposed to the early shot at $1350 \mathrm{ft}$; four were exposed to the open shot, two at $1270 \mathrm{ft}$ and two at $1470 \mathrm{ft}$. Groups of three aboveground utility type shelters, one of masonry blocks, one of precast reinforced concrete, and one of poured-in-place reinforced concrete, were placed at 2250,2750 , and $3750 \mathrm{ft}$ from the open shot. Reinforced-concrete bathroom shelters were placed in rambler type houses (Project 31.1 ) at 2700 and $10,500 \mathrm{ft}$ from the open shot. Three types of basement shelters were constructed in two frame houses (Project 31.1) at 5500 and $7800 \mathrm{ft}$, and two types of basement shelters were constructed in two brick houses (Project 31.1) at 4700 and $10,500 \mathrm{ft}$ from the same burst.

Instrumentation consisted of Wiancko pressure gauges, q-tubes, temperature- and noisemetering devices, gamma-radiation film dosimeters, and neutron detectors. No measurements of structural behavior were made. Mannequins were placed in some shelters on the open shot for demonstration purposes.

On neither shot was structural damage sustained by the large underground personnel shelters. Occupants of the closed shelter would not have been disturbed by blast, debris, or radiation. Damage to the basement exit shelters was inversely proportional to their distance from Ground Zero $(\mathrm{GZ})$ and was directly proportional to the amount of opening in the entrance. The closed shelter at the greatest distance received the least damage but was not satisfactory as a personnel shelter at the lowest pressure tested. Utility shelters provided unsatisfactory protection from radiation. All indoor family type shelters were satisfactory as tested and would have provided adequate protection for occupants. 


\section{ACKNOWLEDGMENTS}

The author wishes to express sincere appreciation to the following individuals for their cooperation in behalf of these projects:

R. L. Corsbie, Atomic Energy Commission, Director, Civil Effects Test Group

Dr. E. F. Cox, Sandia Corporation

L. J. Deal, Atomic Energy Commission

Phyllis Flanders, Sandia Corporation

J. C. Greene, Federal Civil Defense Administration

Dr. P. S. Harris, Los Alamos Scientific Laboratory

R. S. Millican, Sandia Corporation

R. W. Newman, Los Alamos Scientific Laboratory

Dr. G. W. Rollosson, Sandia Corporation

H. H Sander, Sandia Corporation

B. C. Taylor, Federal Civil Defense Administration

Dr. C. S. White, Lovelace Foundation 
$k$ 


\section{CONTENTS}

Page

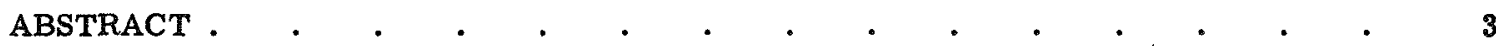

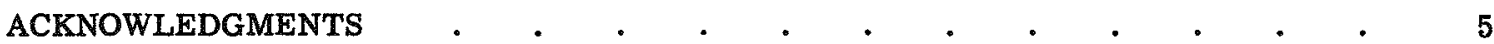

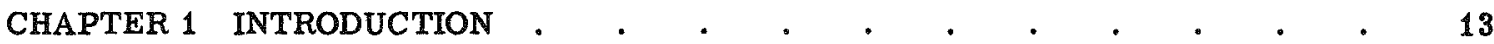

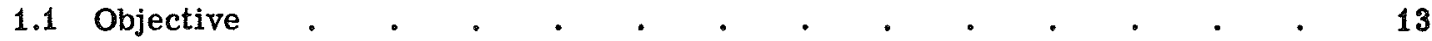

1.2 Background . . . . . . . . . . . . . . 13

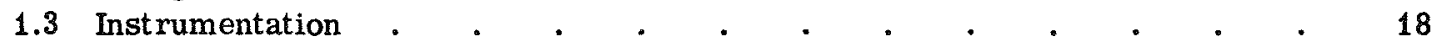

CHAPTER 2 NUCLEAR RADIATION PENETRATION $\quad$ - $\quad$ - $\quad$ - $\quad$ - $\quad$ - $\quad$ - 29

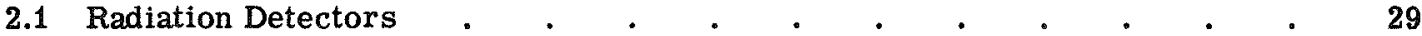

2.2 Incident Radiation . $\quad . \quad$. . . . . . . . . . . . 29

2.2.1 Gamma Radiation . . . . . . . . . . . . 29

2.2.2 Neutron Radiation . . . . . . . . . . . . . . 29

2.3 Underground Personnel Shelter (Structural) . $\quad$. $\quad$. . . . . . . $\quad 32$

2.4 Underground Personnel Shelter (Biomedical) $\quad . \quad$. $\quad . \quad$ • $\quad . \quad$. 32

2.5 Basement Exit Shelters . . . . . . . . . . . . . 33

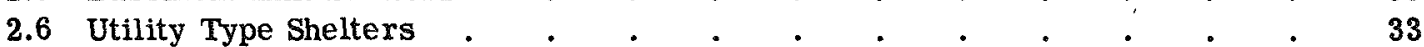

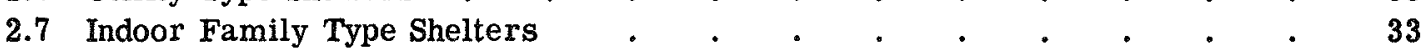

CHAPTER 3 THERMAL CONVECTION . . . . . . . . . . . 50

3.1 Predicted Temperatures . . . . . . . . . . 50

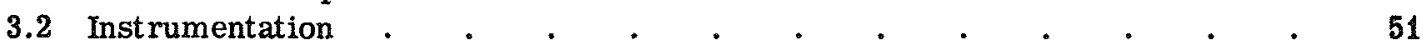

3.3 Results . . . . . . . . . . . . . . . . . . 51

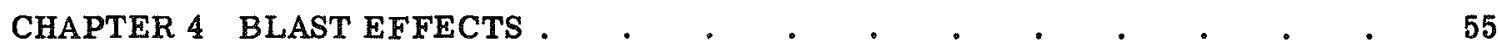

4.1 Underground Personnel Shelter (Structural) . . . . . . . . . . 55

4.1.1 Early Shot (Station 1) . . . . . . . . . . 55

4.1.2 Open Shot (Station $34.3 \mathrm{a}-2$ ) . $\quad . \quad$. $\quad . \quad . \quad . \quad . \quad . \quad 55$

4.2 Underground Personnel Shelter (Biomedical) . . . . . . . . 57

4.2.1 Early Shot (Station 2) . . . . . . . . . . . . . . 57

4.2.2 Open Shot (Station $34.3 \mathrm{~b}-2$ ) $\quad . \quad . \quad . \quad . \quad . \quad . \quad . \quad . \quad . \quad 57$

4.3 Basement Exit Shelters . . . . . . . . . . . . . 57

4.3.1 Early Shot (Stations 3, 4, 5) . . . . . . . . . . . 57

4.3.2 Open Shot (Stations $34.1, \mathrm{c}-1, \mathrm{c}-2, \mathrm{~d}-1, \mathrm{~d}-2$ ) $\quad . \quad . \quad . \quad . \quad . \quad 58$

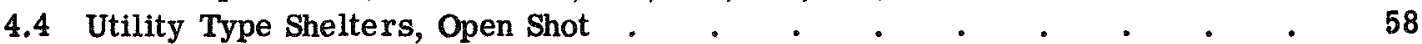




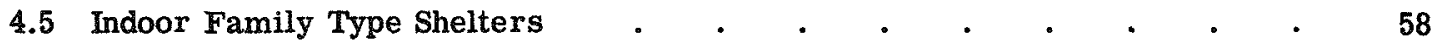

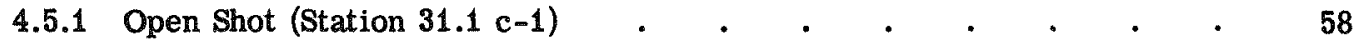

4.5.2 Open Shot (Stations $31.1 \mathrm{a}-1$ and $\mathrm{b}-1$ ) . . . . . . . . 58

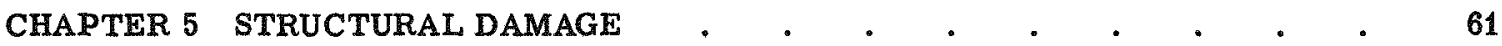

5.1 Underground Personnel Shelters (Structural and Biomedical) . . $\quad$. 61 5.1.1 Open Shot (Stations $34.3 \mathrm{a}-2, \mathrm{~b}-2$ ), $1050 \mathrm{Ft} \quad . \quad$. . . . . 61

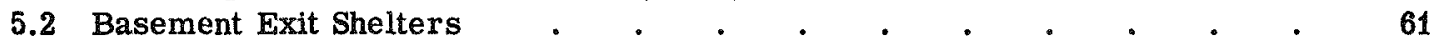
5.2.1 Open Shot (Stations $34.1 \mathrm{c}-1, \mathrm{c}-2, \mathrm{~d}-1, \mathrm{~d}-2) \quad$ ) . . . $\quad$. 61

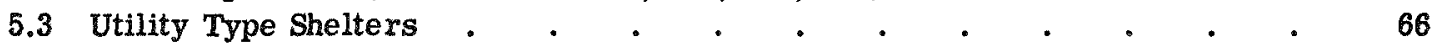

5.3.1 Open Shot (Stations $34.1 \mathrm{e}, \mathrm{f}$, and $\mathrm{g}$ ), $2250 \mathrm{Ft} \quad$. $\quad . \quad$. . . $\quad$. 66

5.3.2 Open Shot (Stations $34.1 \mathrm{~h}, \mathrm{i}$, and j), $2750 \mathrm{Ft} \quad$. . . . . $\quad 66$

5.3.3 Open Shot (Stations $34.1 \mathrm{k}, 1$, and m), $3750 \mathrm{Ft} \quad$. . . . . . 66

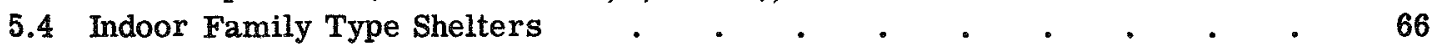

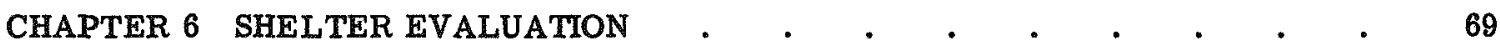

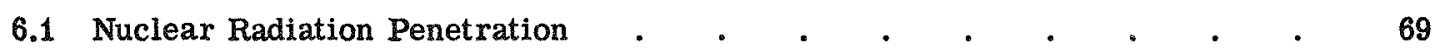

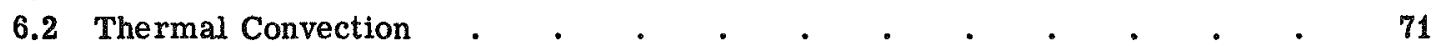

6.3 Blast Effects and Structural Damage . $\quad . \quad$. $\quad . \quad$. $\quad . \quad$. $\quad$. 74

6.4 General. $. \quad . \quad . \quad . \quad . \quad . \quad . \quad . \quad . \quad . \quad . \quad 74$

CHAPTER 7 CONCLUSIONS AND RECOMMENDATIONS $\quad$ - . . . . . . $\quad$. 78

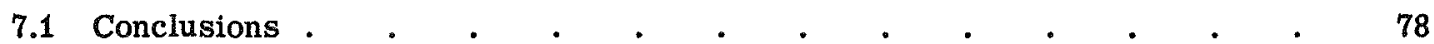

7.1 .1 Radiation Penetration $. \quad . \quad . \quad . \quad . \quad . \quad . \quad . \quad . \quad 78$

7.1 .2 Thermal Convection . . . . . . . . . . . . . $\quad$. 78

7.1.3 Blast Effects and Structural Damage (Open Shot) . . . . 78

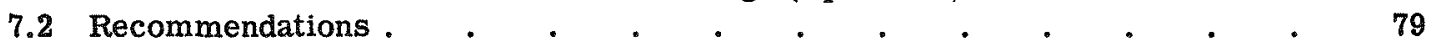

7.2.1 Radiation Penetration . . . . . . . . . . . 79

7.2.2 Thermal Convection . . . . . . . . . . . . 79

7.2.3 Blast Effects and Structural Damage . . . . . . . 79

APPENDIX A DESIGN OF AN UNDERGROUND PERSONNEL SHELTER . $\quad$ • $\quad$ • 81

A.1 General . . . . . . . . . . . . . 83

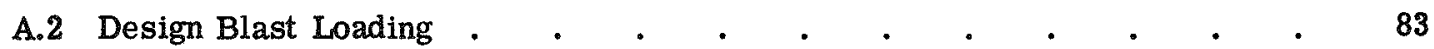

A.3 Strength Criteria . . . . . . . . . . . . . . . $\quad . \quad 83$

A.4 Design . . . . . . . . . . . . . . . . . . . 44

A.5 Analyses . . . . . . . . . . . . . . . $\quad . \quad$. 84

A.6 Architectural and Structural Drawings . . . . . . . . . . $\quad$. 84

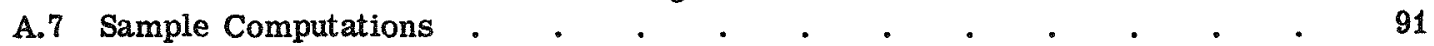

A.7.1 Roof Slab Design . . . . . . . . . . . . . . $\quad .91$

A.7.2 Resistance Function . . . . . . . . . . . 94

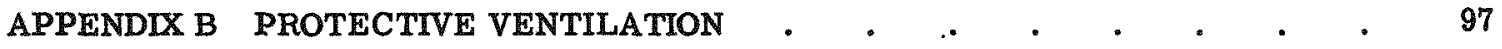

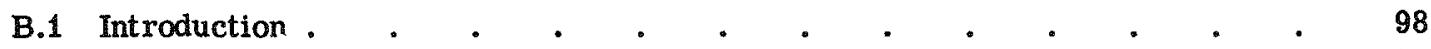

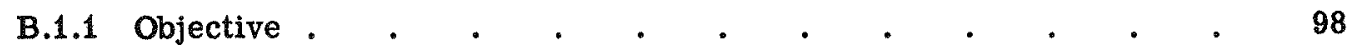

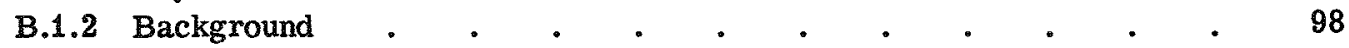

B.1.3 Preshot Development Work (Diffusion Shelter) . . • . $\quad$. 99

B.1.4 Preshot Development Work (Pressurized Type of Shelter) . $\quad$. 106 


\section{CONTENTS (Continued)}

B.2 Test Results

B.2.1 Test Results on the Diffusion Shelter . . . . . . . 114

B.2.2 Test Results on Pressurized Shelter . . . . . . . 117

B.3 Discussion . . . . . . . . . . . . . 118

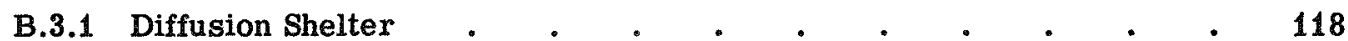

B.3.2 Pressurized Shelter . $\quad$. $\quad$. $\quad$. $\quad$. $\quad . \quad$. $\quad . \quad$. 119

B.4 Conclusions and Recommendations . . . . . . . . . 120

B.4.1 Conclusions . . . . . . . . . . . 120

B.4.2 Recommendations . . . . . . . . . . . . 120

\section{ILLUSTRATIONS}

\section{CHAPTER 1 INTRODUCTION}

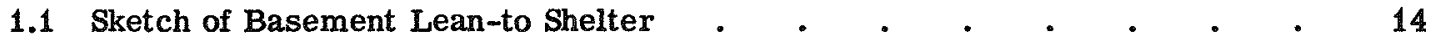

1.2 Basement Lean-to Shelter . . . . . . . . . . 14

1.3 Basement Corner-room Shelter . $\quad$ - . . . . . . . $\quad$. 15

1.4 Sketch of Basement Corner-room Shelter . . . . . . . . $\quad$. 15

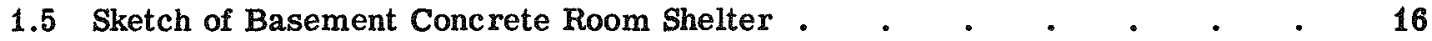

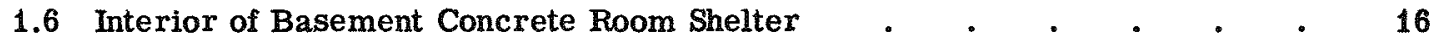

1.7 Interior of Bathroom Shelter. $. \quad . \quad . \quad . \quad . \quad . \quad . \quad . \quad . \quad 17$

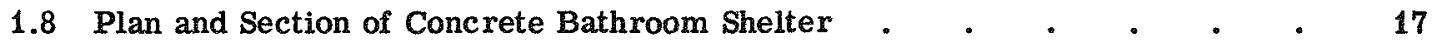

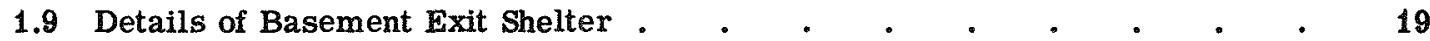

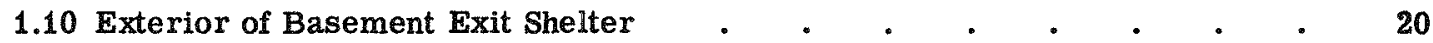

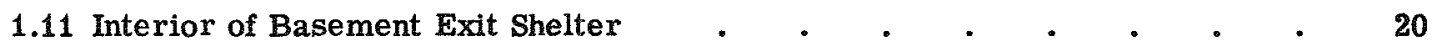

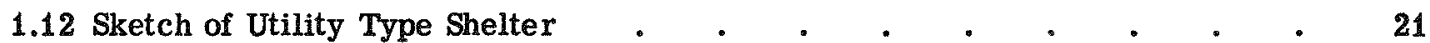

1.13 Exterior of Masonry Utility Type Shelter . . . . . . . $\quad$ - 21

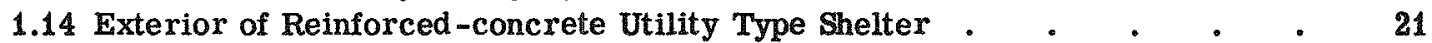

1.15 Interior of Underground Personnel Shelter (Unfinished) $\quad . \quad$. $\quad$ - 22

1.16 Interior of Underground Personnel Shelter (Finished) . . . . - . 22

1.17 Plan and Section of Underground Personnel Shelter

(Structural), Early Shot.

1.18 Plan and Section of Underground Personnel Shelter (Structural), Open Shot .

1.19 Plan and Section of Underground Personnel Shelter

(Biomedical), Early and Open Shots . . . . . . . . 25

1.20 Fast-fill Room of Partitioned Underground Personnel Shelter . . . 26

1.21 Slow-fill Room of Partitioned Underground Personnel Shelter . . . 26

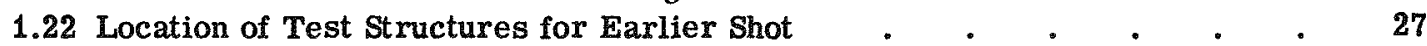

1.23 Location of Test Structures for Open Shot . . . . . . . . 27

\section{CHAPTER 2 NUCLEAR RADIATION PENETRATION}

2.1 Incident Gamma Radiation Vs Distance . $\quad$. $\quad$. $\quad$. . . $\quad$. 30

2.2 Incident Neutron Radiation, Open Shot . . . . . . . . . $\quad 31$

2.3 Gamma Radiation (in Roentgens) in Underground Personnel

Shelter (Structural), Open Shot 


\section{ILLUSTRATIONS (Continued)}

Page

2.4 Gamma Radiation (in Roentgens) in Underground Personnel Shelter (Biomedical), Open Shot . . . . . . . . . . 33

2.5 Gamma Radiation in Basement Exit Shelters, Open Shot _ . . . $\quad$ - 34

2.6 Film Dosimeter and Neutron Detector Locations in Underground Personnel Shelter (Structural), Open Shot . . . . . . . 36

2.7 Film Dosimeter and Neutron Detector Locations in Underground Personnel Shelter (Biomedical), Open Shot . . . . . . . 38

2.8 Film Dosimeter and Neutron Detector Locations in Basement Exit Shelters, Open Shot . • . . . . . . . . . 42

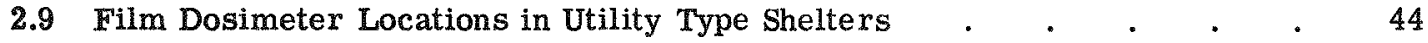

2.10 Film Dosimeter Locations in Reinforced-concrete Bathroom Shelter in Rambler Houses . • . . . . . . . . 45

2.11 Film Dosimeter Locations in Basement Reinforced-concrete Room Shelter in Two-story Frame Houses . . . . . . . . 46

2.12 Film Dosimeter Locations in Basement Corner-room Shelters in Two-story Houses . . . . . . . . . . . . . 48

2.13 Film Dosimeter Locations in Basement Lean-to Shelters in Two-story Houses. $. \quad . \quad . \quad . \quad . \quad . \quad$. . . . 49

\section{CHAPTER 3 THERMAL CONVECTION}

3.1 Temperature and Overpressure in Fast-fill Room, Underground Personnel Shelter, Open Shot .

3.2 Temperature and Overpressure in Slow-fill Room,
Underground Personnel Shelter, Open Shot.

\section{CHAPTER 4 BLAST EFFECTS}

4.1 Acceleration, Velocity, and Displacement Records, Underground Personnel Shelter, Open Shot

4.2 Pressure-time Records, Open Shot

4.3 Pressure-time Records, Open Shot

\section{CHAPTER 5 STRUCTURAL DAMAGE}

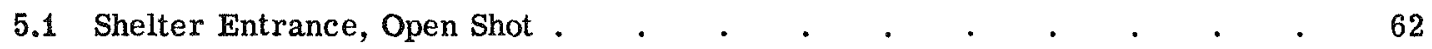

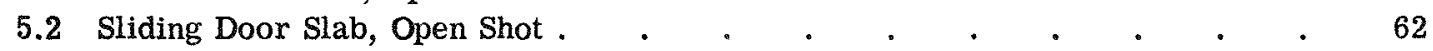

5.3 Entrance to Closed Basement Exit Shelter, 1270 Ft, Open Shot . . . 63

5.4 Entrance to Closed Basement Exit Shelter, $1470 \mathrm{Ft}$, Open Shot . . . . 63

5.5 Entrance to Open Basement Exit Shelter, 1270 Ft, Open Shot . . . . 64

5.6 Entrance to Open Basement Exit Shelter, $1470 \mathrm{Ft}$, Open Shot . . . $\quad 64$

5.7 Interior of Open Basement Exit Shelter, $1470 \mathrm{Ft}$, Open Shot . $\quad$ - $\quad$. $\quad$ - $\quad 65$

5.8 Debris from Masonry Utility Type Shelter, $2250 \mathrm{Ft}$, Open Shot . . . . 67

5.9 Reinforced-concrete (Poured-in-place) Utility Type Shelter,

5.10 Reinforced-concrete (Precast) Utility Type Shelter,

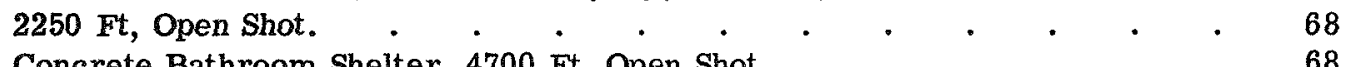

5.11 Concrete Bathroom Shelter, $4700 \mathrm{Ft}$, Open Shot . . . . . . . 68

\section{CHAPTER 6 SHELTER EVALUATION}

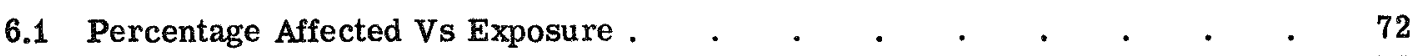

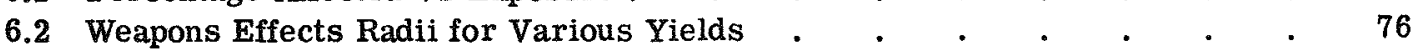




\section{ILLUSTRATIONS (Continued)}

APPENDIX A DESIGN OF AN UNDERGROUND PERSONNEL SHELTER

A.1 Architectural Plans and Sections, Underground Personnel

Shelter

A.2 Plans, Sections, and Details, Underground Personnel

Shelter.

A.3 Entrance, Sections, and Details, Underground Personnel

Shelter.

A.4 Sliding Door and Escape-hatch Details, Underground

Personnel Shelter.

A.5 Airtight Steel-plate Door Details, Underground Personnel

Shelter.

APPENDIX B PROTECTIVE VENTILATION

B.1 Air Inlet Equipment Installation . . . . . . . . . 100

B.2 Front Wall Framing Construction, Showing Closet . . . . 100

B.3 Air Exhaust Antiblast Closure Installation . . . . . . . 101

B.4 Air Exhaust Equipment and Closet . . . . . . . . 101

B.5 Incomplete Construction Around Escape Hatch . . . . . 102

B.6 Incomplete Construction Around Entrance Door . . . . . . 102

B.7 Wall Seals Around Escape Hatch . . . . . . . . . . 103

B.8 Completed Installation Around Entrance Door . . . . . . 103

B.9 Exterior View of Underground Personnel Shelter . . . . . . 107

B.10 Air Exhaust Chamber . . . . . . . . . . . 107

B.11 Motor Generator in Air Exhaust Chamber . . . . . . . 108

B.12 Entrance Door to Air Exhaust Chamber . . . . . . . 108

B.13 Wood Panel Between Inlet and Exhaust Air Chamber . . . . . 109

B.14 Equipment in Inlet Air Chamber . . . . . . . . . 109

B.15 Layout of Pressurized Shelter . . . . . . . . . 110

B.16 Wiring Diagram for Shelter 34.3 a-2 (115-volt Alternating Current) . . . . . . . . . . . 113

B.17 Laboratory Data of Flow Vs Power Input . . . . . . . 116

B.18 Flow Measurements for Measured Power Values Compared with Flow Through Anti-back Draft Valves and Shelter

Leakage

\section{TABLES}

\section{CHAPTER 1 INTRODUCTION}

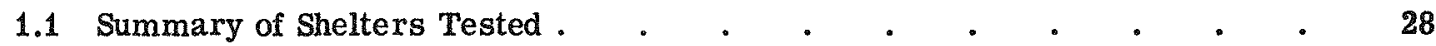

\section{CHAPTER 2 NUCLEAR RADIATION PENETRATION}

2.1 Average Gamma Radiation Inside Family Type Shelters _ - . - . 35

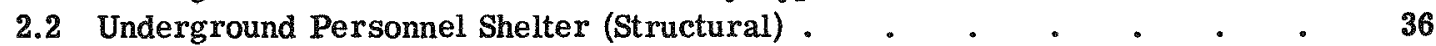

2.3 Underground Personnel Shelter (Biomedical) $\quad$ - . . . . . . . 37

2.4 Basement Exit Shelter (Closed) • . . . . . . . . . . 39 


\section{TABLES (Continued)}

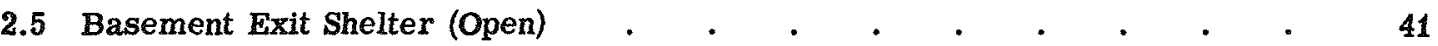

2.6 Utility Shelter (Film Dosimeters). . . . . . . . . . . $\quad .43$

2.7 Utility Shelter (Film Dosimeters) . . . . . . . . . . . $\quad .43$

2.8 Utility Shelter (Film Dosimeters) . . . . . . . . . . . . $\quad 44$

2.9 Reinforced-conc rete Bathroom Shelter (Film Dosimeters) . . . $\quad$. 45

2.10 Basement Reinforced-concrete Shelter (Film Dosimeters) . . . . $\quad 46$

2.11 Basement Corner-room Shelter (Film Dosimeters) . . . . . $\quad 47$

2.12 Basement Lean-to Shelter (Film Dosimeters) $\quad$ - . . . . . . $\quad$. 49

CHAPTER 3 THERMAL CONVECTION

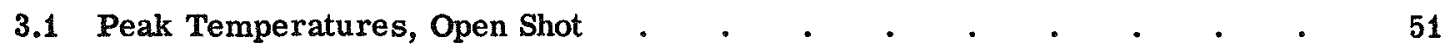

CHAPTER 6 SHELTER EVALUATION

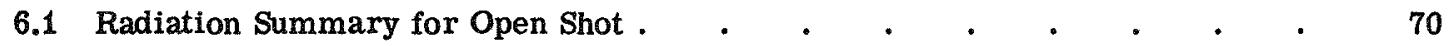

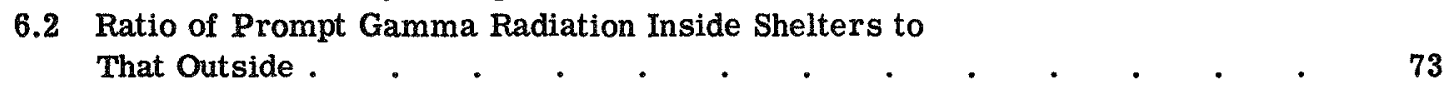

APPENDIX B PROTECTIVE VENTILATION

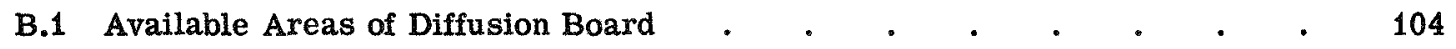

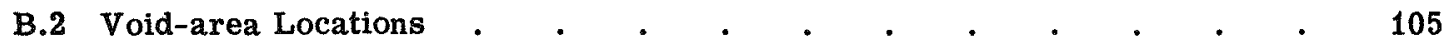

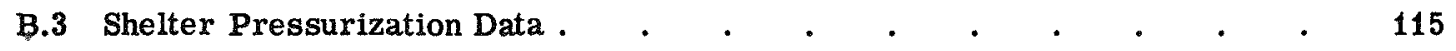




\section{CHAPTER 1}

\section{INTRODUCTION}

\subsection{OBJECTIVE}

The primary purpose of Projects 34.1 and 34.3 was to evaluate shelter designs proposed by the Federal Civil Defense Administration (FCDA) for protection against nuclear and thermal radiation and blast effects. The effectiveness of two types of protective ventilation for buried shelters was evaluated by the Army Chemical Center. Advantage was taken of the instrumentation provided for Program 33 to obtain a better understanding of blast loading inside an underground shelter.

\subsection{BACKGROUND}

Lehigh University Institute of Research designed for FCDA several types of home shelters of which four types [(1) covered-trench, (2) metal-arch, (3) wood-arch, and (4) basement leanto] were field-tested during Operation Buster-Jangle. ${ }^{1}$ Weaknesses in the more successful of these shelters were strengthened, and these modified versions, together with designs of new shelter types, were tested during Operation Upshot-Knothole. ${ }^{2}$ A basement lean-to shelter similar to that tested during Operation Buster-Jangle and a newly designed basement cornerroom shelter were located in the basements of two frame test houses on Operation UpshotKnothole. The houses were exposed to approximately 5 and 1.7 psi, but no instrumentation was provided to determine the relation of outside overpressure to that to which occupants of the shelter would have been subjected. The manner in which failure of these two frame houses occurred was such that maximum debris did not load the shelters. It was desired also to test these shelters under the greater debris load of a brick house. Thus, for Operation Teapot, basement lean-to (Figs. 1.1 and 1.2) and basement corner-room shelters (Figs. 1.3 and 1.4) were placed in all the brick and frame houses with basements. The designs were essentially the same as those tested on Operation Upshot-Knothole except that the width of the basement leanto shelter had been reduced from 8 to $6 \mathrm{ft}$. A shelter consisting of a narrow room of reinforced concrete was constructed in the basement next to the stair well of the frame houses of Operation Teapot (Figs. 1.5 and 1.6).

Since many houses in the United States do not have basements, another new type of indoor home shelter was designed by FCDA. This consisted of modifying the bathroom of a conventional one-story frame residence built on a flat slab. Bathroom walls and ceiling were made of 8-in. reinforced concrete, the thickness of the floor slab was increased from 4 to 12 in., and the window and door were covered with blast doors made of two thicknesses of 1-in. plywood which were glued and screwed together (Figs. 1.7 and 1.8).

A basement exit shelter which connects to the house through the basement wall was also tested during Operation Upshot-Knothole. The shelter was exposed to about 23 psi and was 


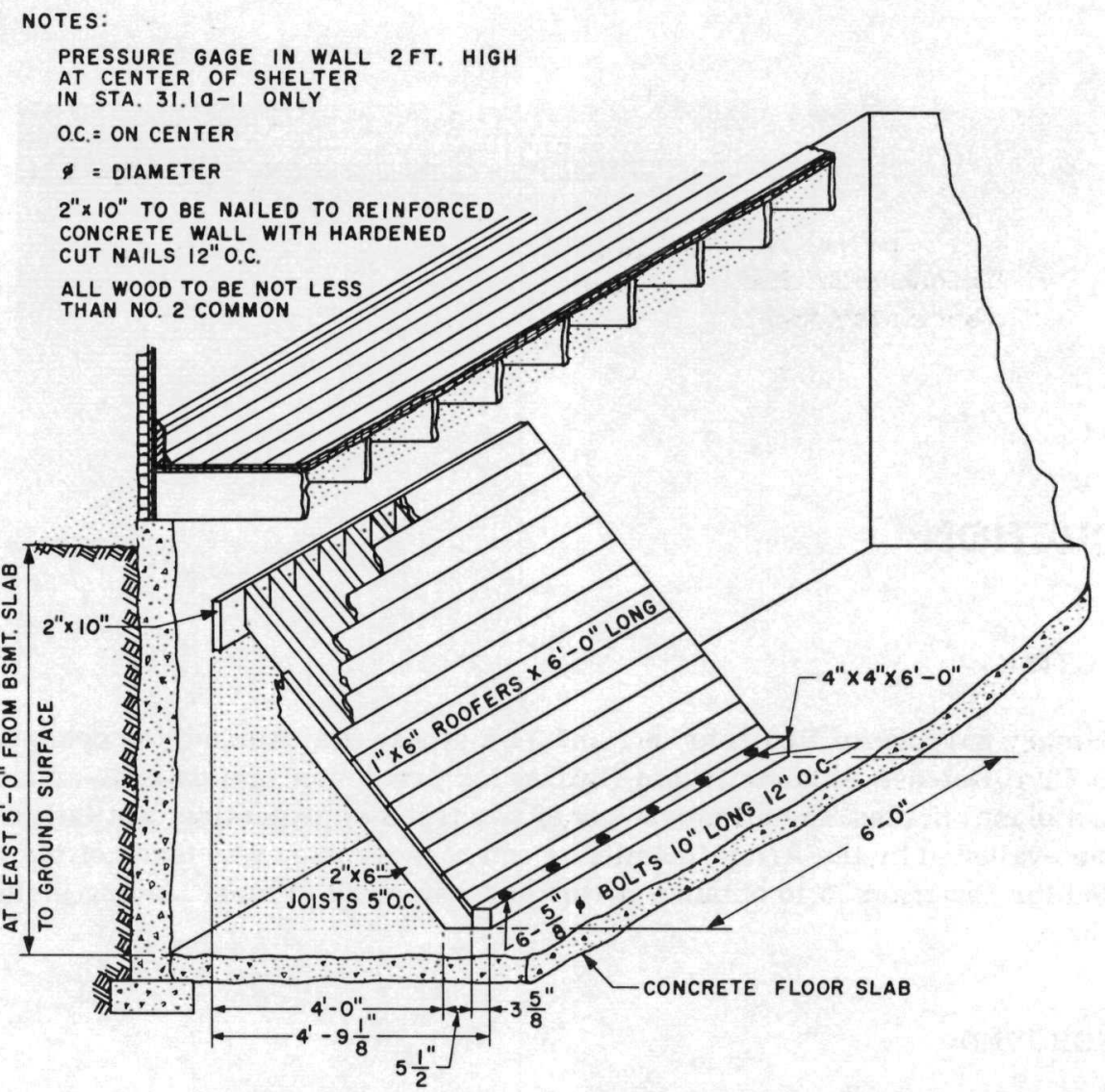

Fig. 1.1 - Sketch of basement lean-to shelter.

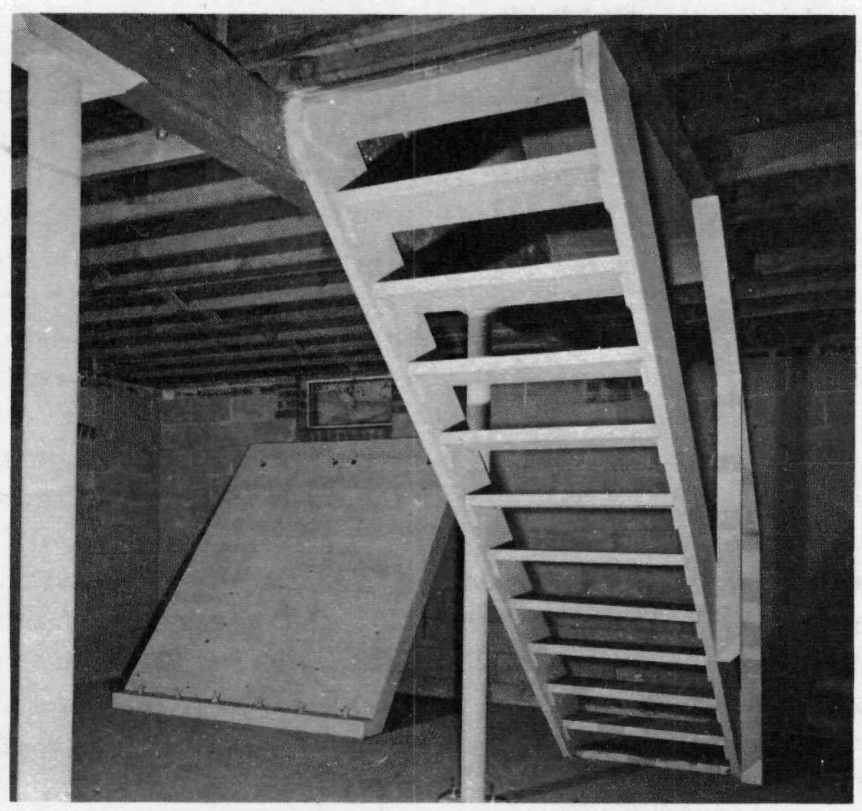

Fig. 1.2-Basement lean-to shelter. 


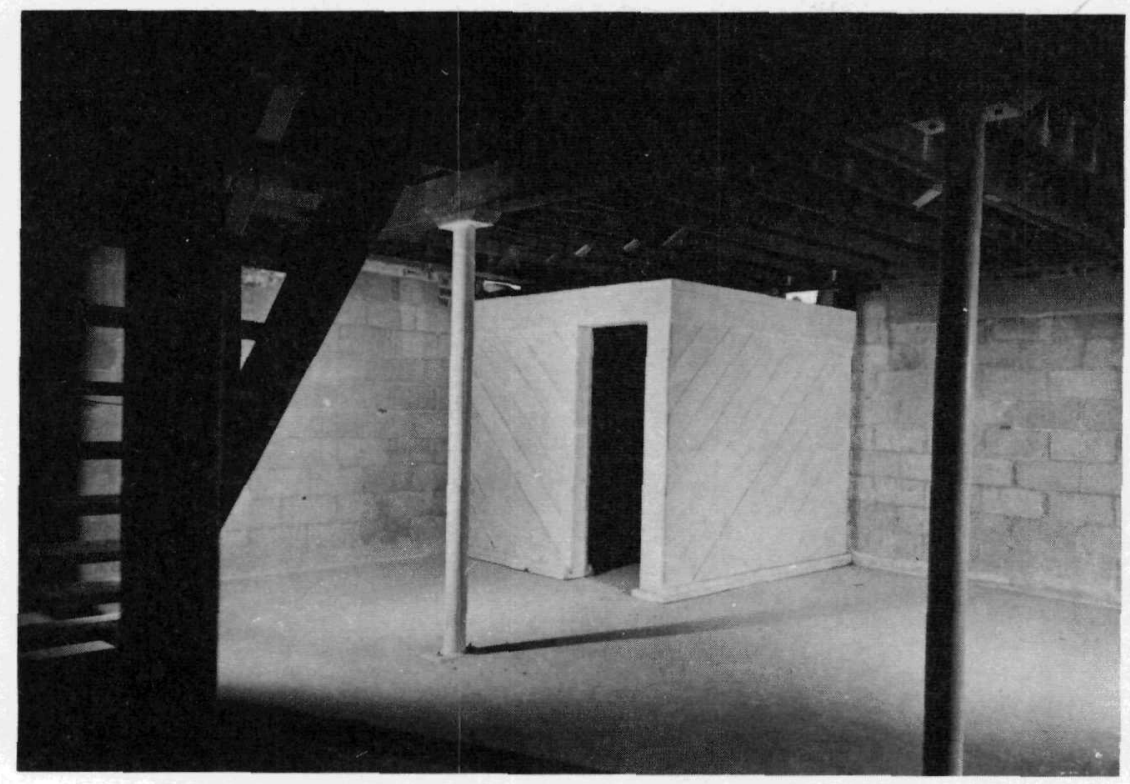

Fig. 1.3-Basement corner-room shelter.

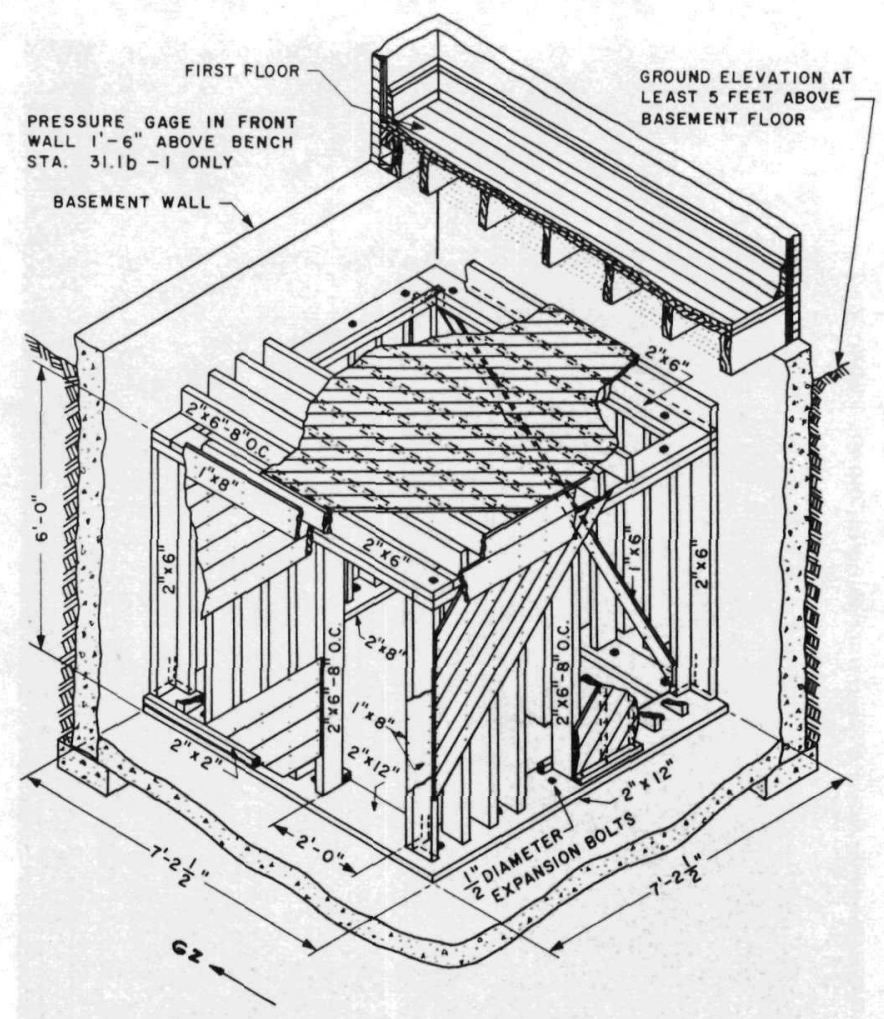

Fig. 1.4-Sketch of basement corner-room shelter. 


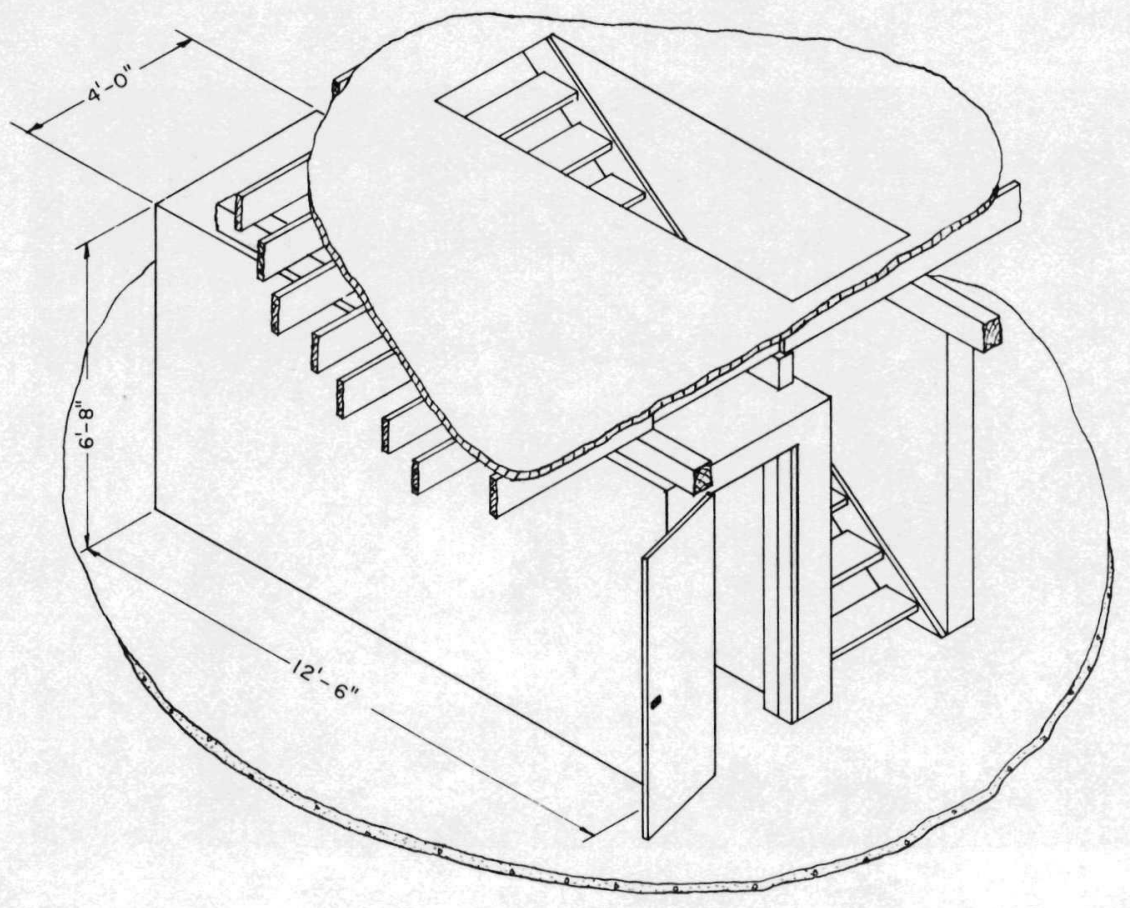

Fig. 1.5 - Sketch of basement concrete room shelter.

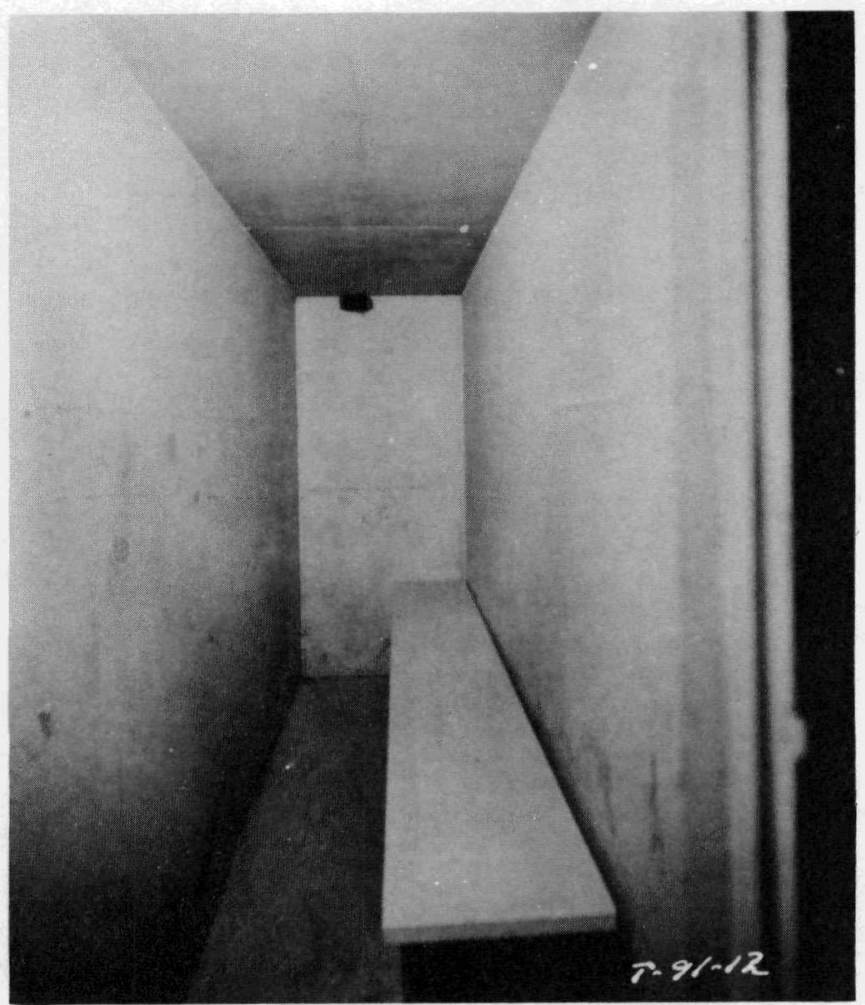

Fig. 1.6 - Interior of basement concrete room shelter. 


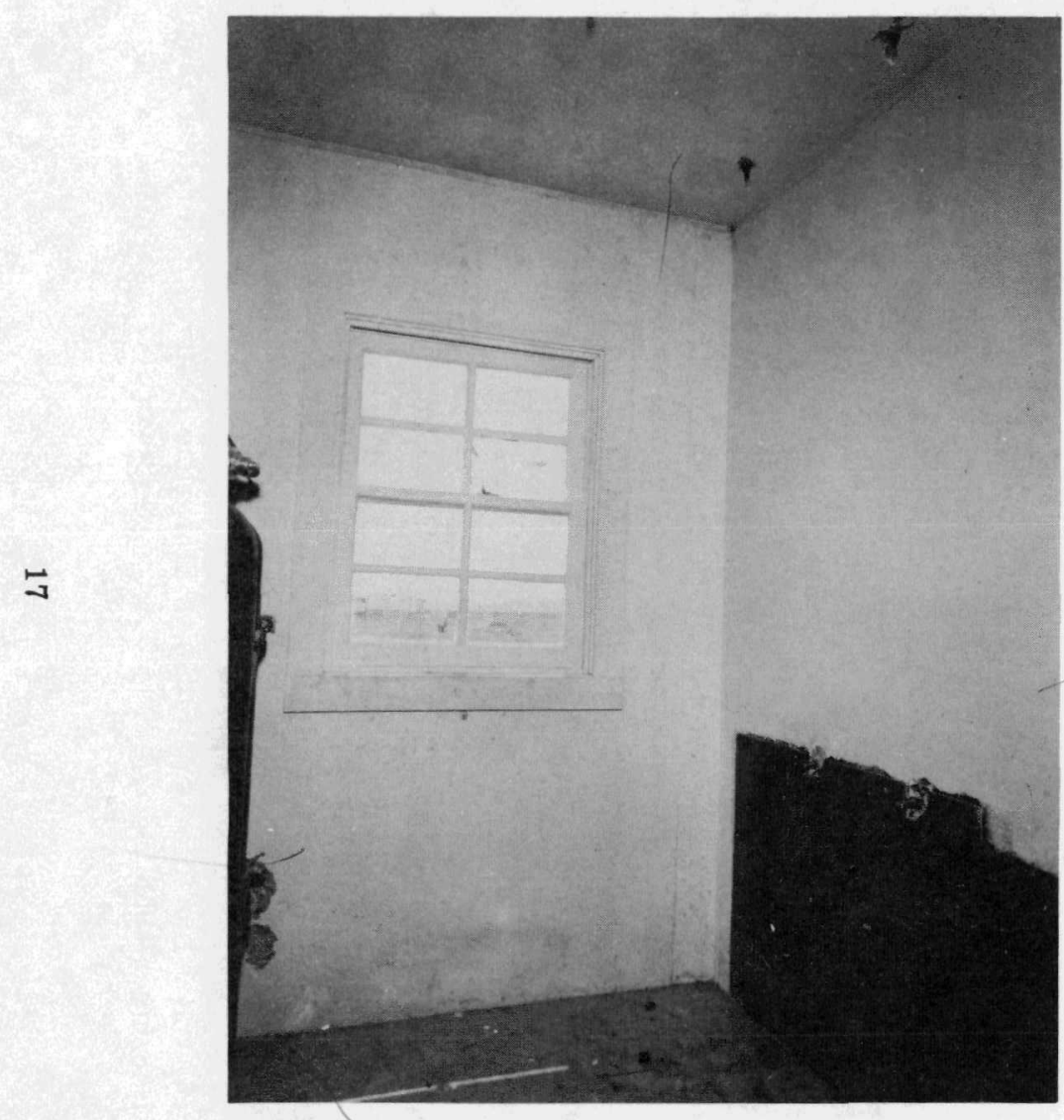

Fig. 1.7-Interior of bathroom shelter.
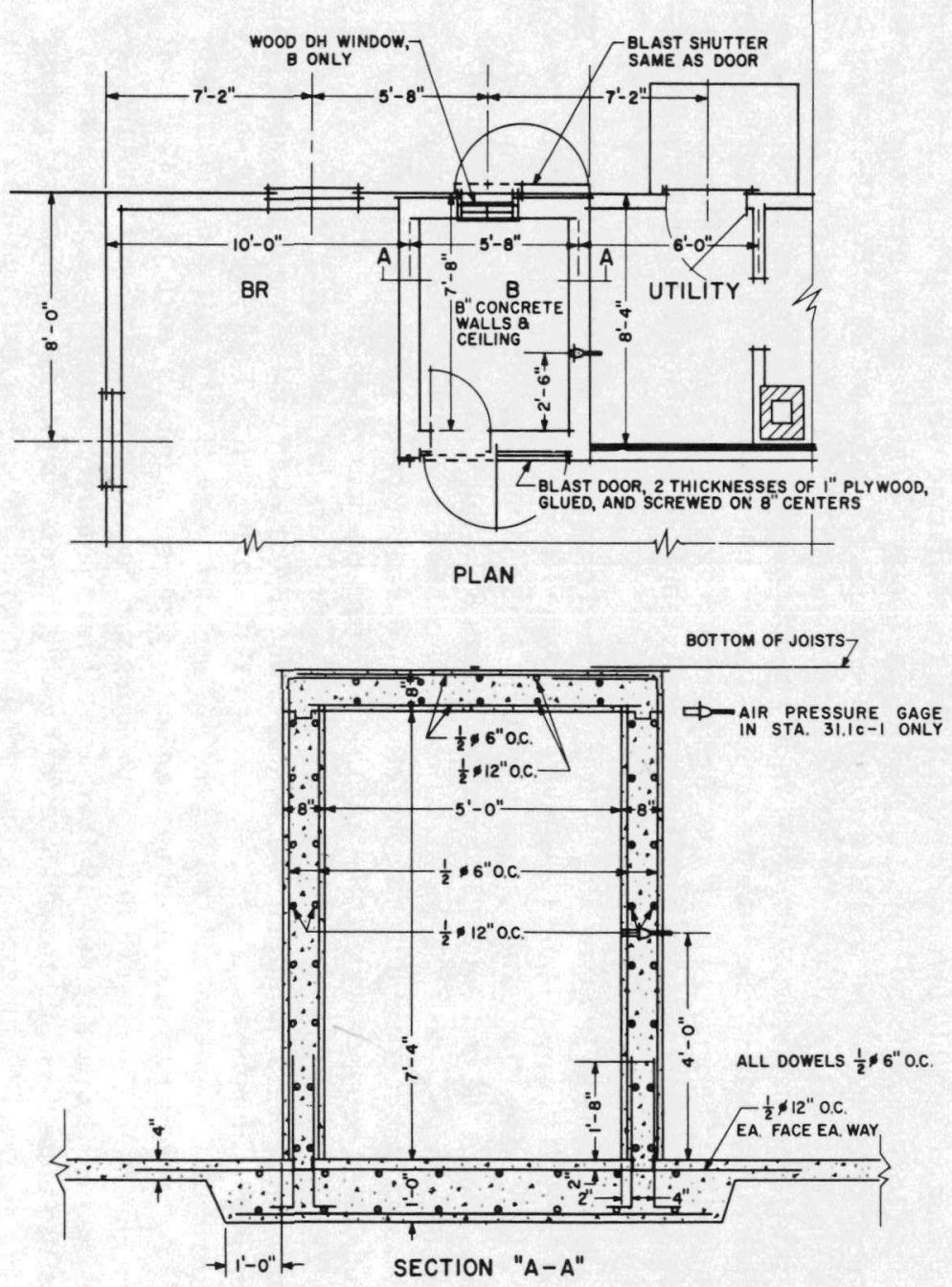

Fig. 1.8-Plan and section of concrete bathroom shelter. 
located with the entrance end toward Ground Zero (GZ) with the entrance oriented $90^{\circ}$ from GZ. It was desired to evaluate this shelter at a higher pressure level, with a blast-resistant door, and at its most vulnerable orientation with the entrance facing GZ. Other than the addition of the door, the only significant change in the Upshot-Knothole design was an increased thickness of reinforced concrete in the wall of the entrance (Figs. 1.9 through 1.11). For Operation Teapot three shelters were tested on the earlier shot: one with the four-section door closed, one with the two center sections of the door removed, and one without a door. Shelters on the open shot were tested in pairs, one with the door closed and one without a door, each at two different pressure levels. The varying door openings were a requirement of Program 33 but gave information on the overpressures to which occupants would be subjected under the conditions tested.

An aboveground utility type shelter was designed by Ammann \& Whitney from a concept furnished by FCDA, which could be used as a tool shed when not needed as a shelter (Figs. 1.12 through 1.14). Inside floor dimensions were 6 by $6 \mathrm{ft}$, and the interior was $7 \mathrm{ft}$ high. Walls were 6 in. thick, except the wall with the door, which was 8 in. thick. An outside blast door of $3-$ by 8-in. lumber was provided. Three variations of this shelter were designed and constructed masonry block, precast reinforced concrete, and poured-in-place reinforced concrete. One of each of the three types was tested at three different pressure levels.

The FCDA was aware of the need for providing shelters for industrial and civic use and furnished requirements to Ammann \& Whitney, who designed an underground personnel shelter to accommodate 50 persons (Figs. 1.15 through 1.17, earlier shot; Fig. 1.18, open shot). Two were built for the open shot and two for the earlier shot. One of each pair was modified by a reinforced-concrete partition dividing the shelter into two chambers, each 12 by 12 by $8 \mathrm{ft}$ (Figs. 1.19 through 1.21 ). These were tested with doors and escape hatches open but partially obstructed (hatches had air inlet -19-in. diameter for the earlier shot; 36-in. diameter for the open shot) to meter air into the chambers at a rate satisfactory to the requirements of the biomedical program (Program 33). The room into which the escape hatch entered is referred to as the "slow-fill" room and the other as the "fast-fill" room. Three shelters were oriented with the entrance toward $\mathrm{GZ}$, and the fourth (Station $34.3 \mathrm{a-2}$ ) was rotated $90^{\circ}$ counterclockwise (Fig. 1.22).

Table 1.1 lists the shelters tested on Operation Teapot. Actual station numbers are used for the open shot; station designations selected only for purposes of this report are used for the early shot. Five outdoor underground personnel types were tested on the earlier shot (Fig. 1.22). Six outdoor underground, nine outdoor aboveground, and twelve indoor shelters were tested on the open shot (Fig. 1.23).

\subsection{INSTRUMENTATION}

Gauges allotted to each shelter are listed in Table 1.1; gauge locations within the shelters are shown in Figs. 1.1, 1.4,1.8, 1.9, 1.12, 1.17, 1.18, and 1.19. The locations of ground baffle gauges provided by Project 39.2 (reference 3 ) for measuring "free field" presssures are shown in Figs. 1.22 and 1.23. Instrumentation for noise was made for the benefit of Project 33.2 and is covered in the Project 33.2 report. ${ }^{4}$ Temperature gauges in the open group shelters were designed to measure transient temperatures (see Chap. 3 for gauge details).

\section{REFERENCES}

1. A. P. Flynn, FCDA Family Shelter Evaluation, Operation Buster Report, WT-359, March 1952.

2. J. B. Byrnes, Effects of an Atomic Explosion on Underground and Basement Type Home Shelters, Operation Upshot-Knothole Report, WT-801, March-June 1953.

3. G. W. Rollosson, Static and Dynamic Overpressure Measurements, Operation Teapot Report, ITR-1192 (to be superseded by WT-1192).

4. F. G. Hirsch et al., The Effects of Noise on Biological Systems, Operation Teapot Report, WT-1180, December 1955. 


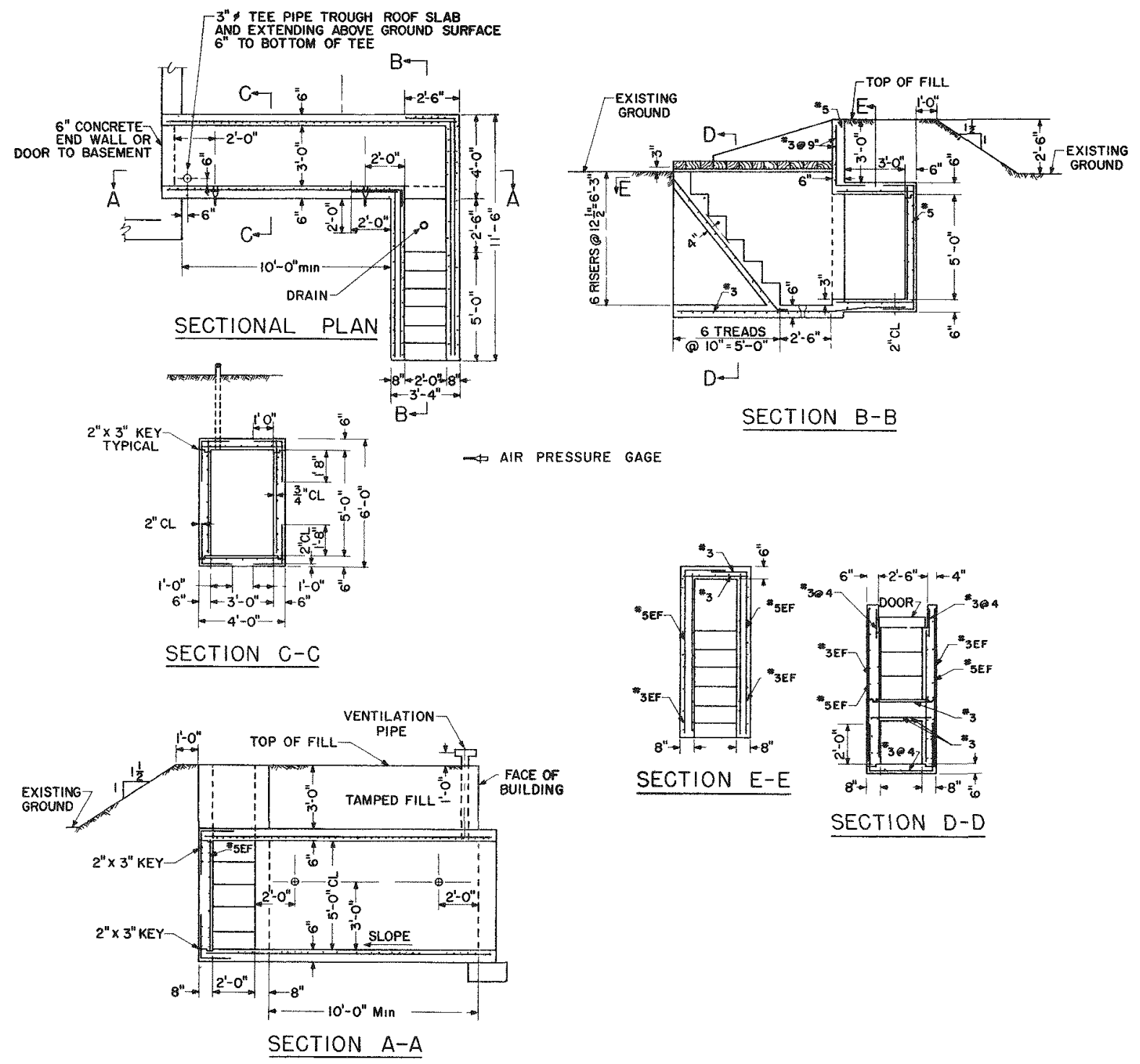

Fig. 1.9-Details of basement exit shelter. 


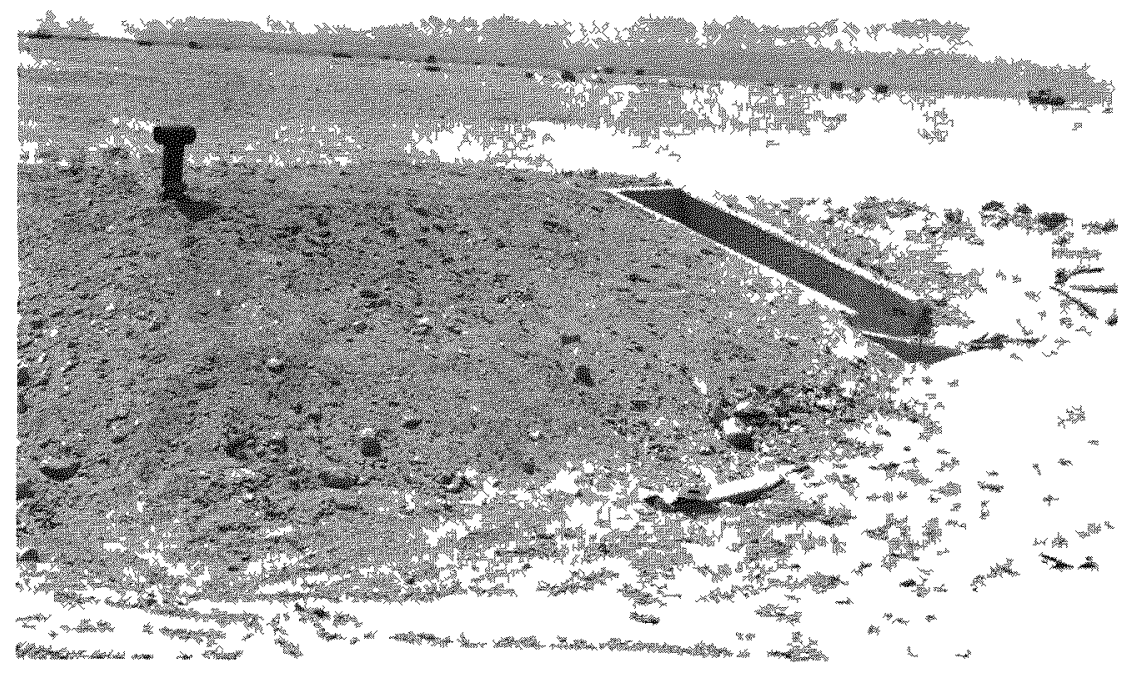

F1g. 1.10-Exterior of basement exit shelter.

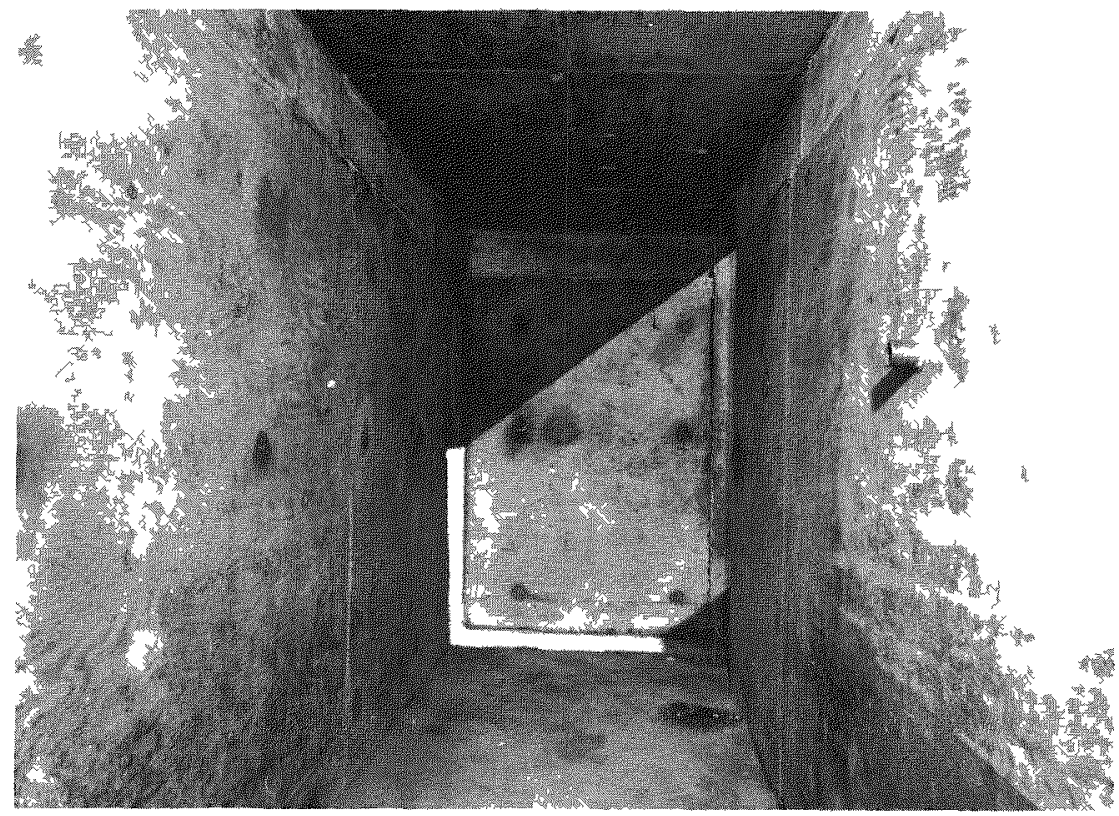

Fig. 1.11-Interior of basement exit shelter. 


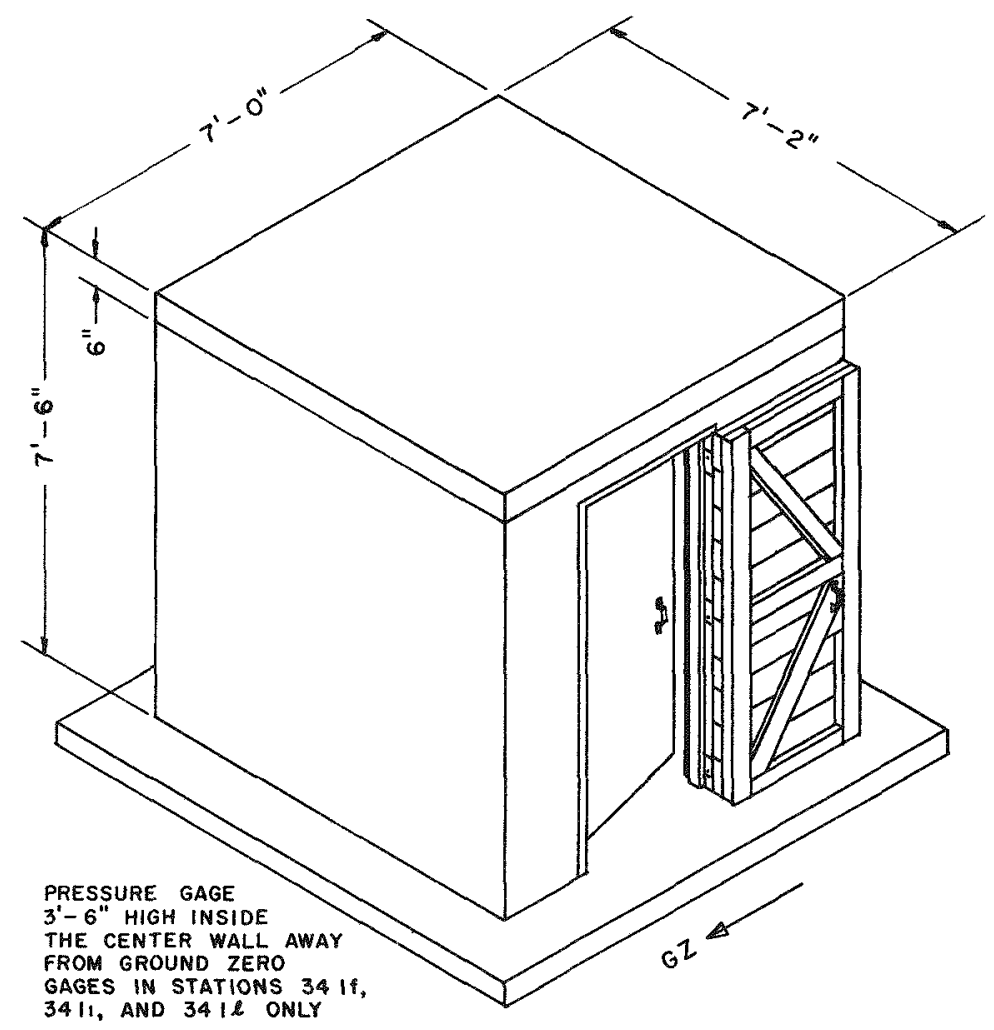

Fig. 1.12-Sketch of utulity type shelter; Stations 34.1 e to $\mathrm{m}$.

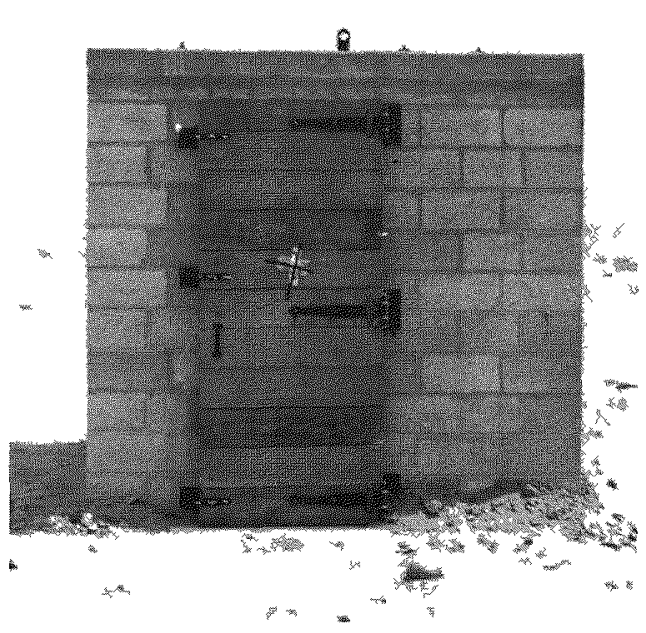

Fig. 1.13-Exterior of masonry utality type shelter: Stauons $34.1 \mathrm{~g}, \mathrm{~J}$, and $\mathrm{m}$.

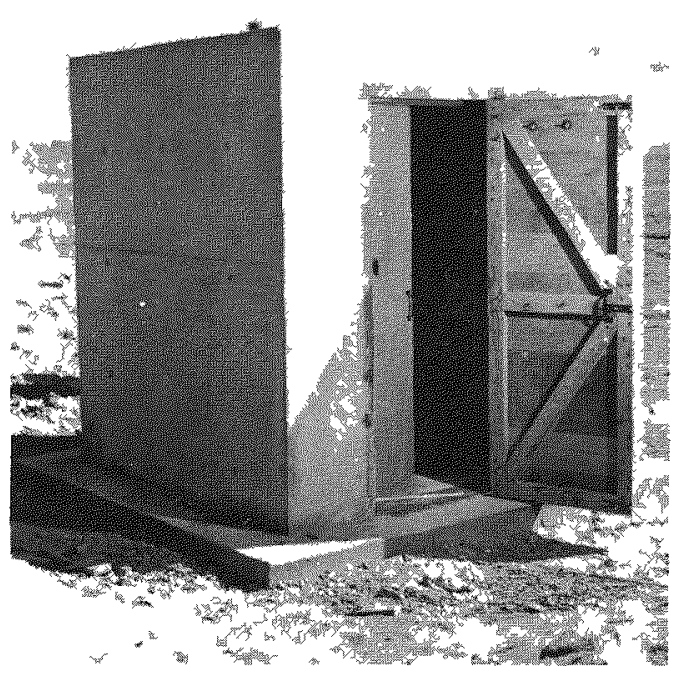

Fig. 1.14-Exterior of reinforced-concrete urility type shelter: Stations $34.1 \mathrm{f}, \mathrm{i}$, and $\mathrm{l}_{\text {. }}$ 


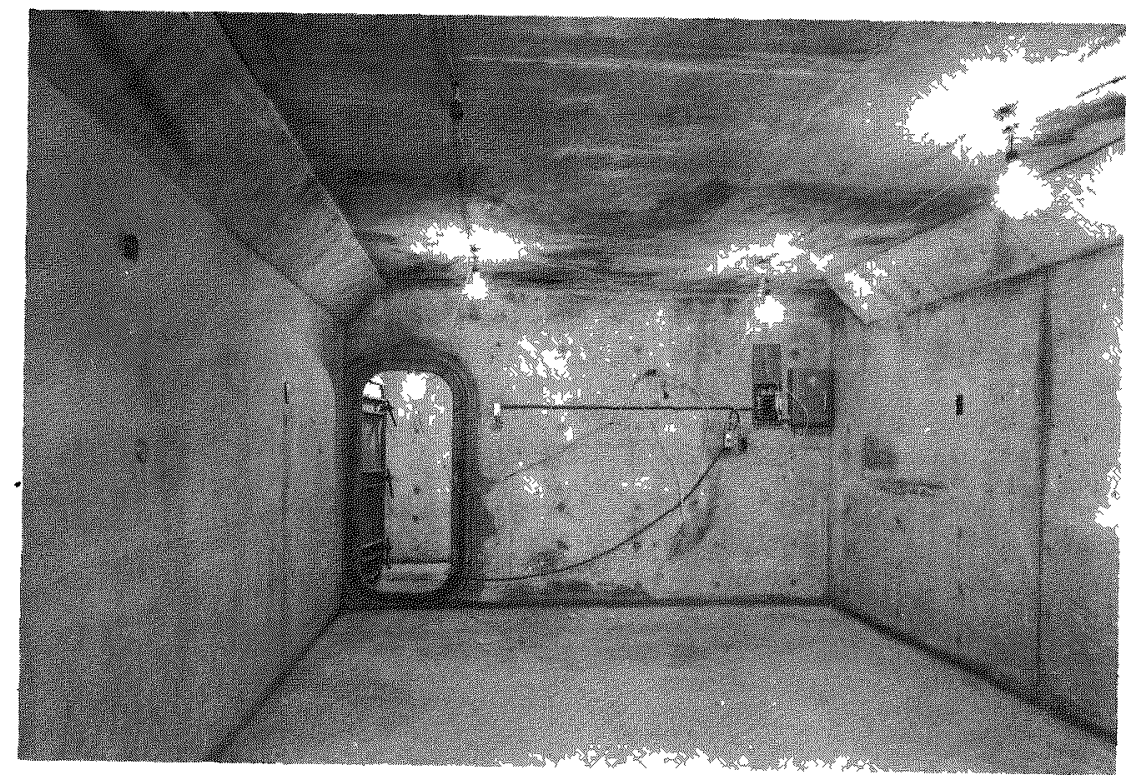

Fig. 1.15 - Interior of underground personnel shelter (unfinished); Station 1.

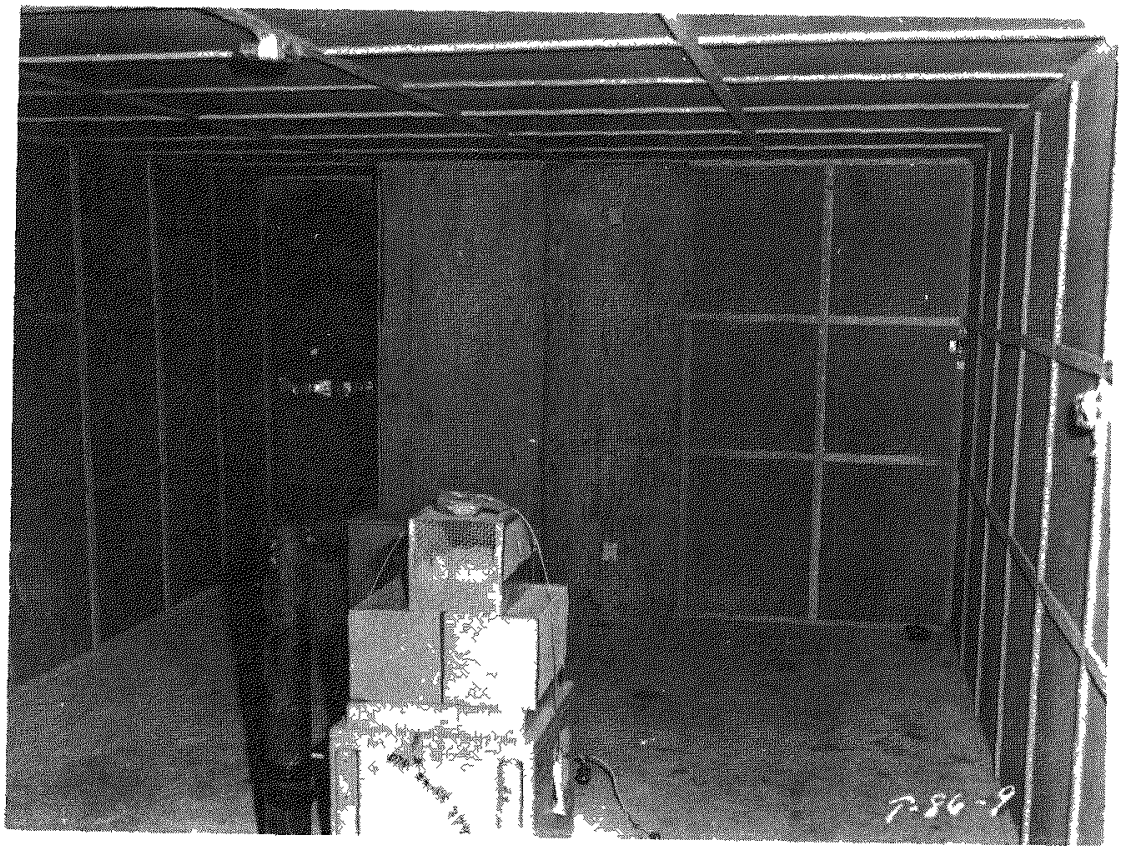

Fig. 1.16 - Interior of underground personnel shelter (finished): Station 1. 


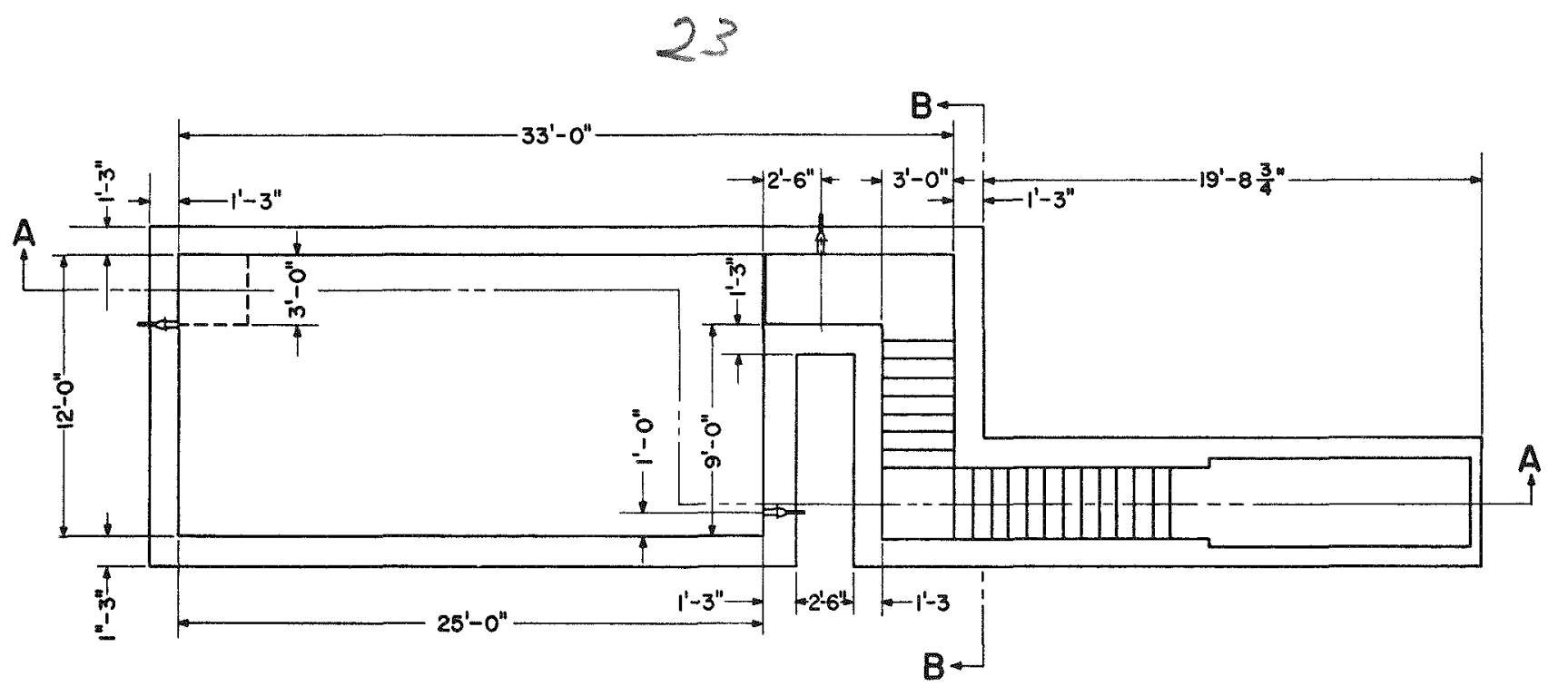

$\approx$

ऋ AIR PRESSURE GAGE 4' ABOVE FLOOR

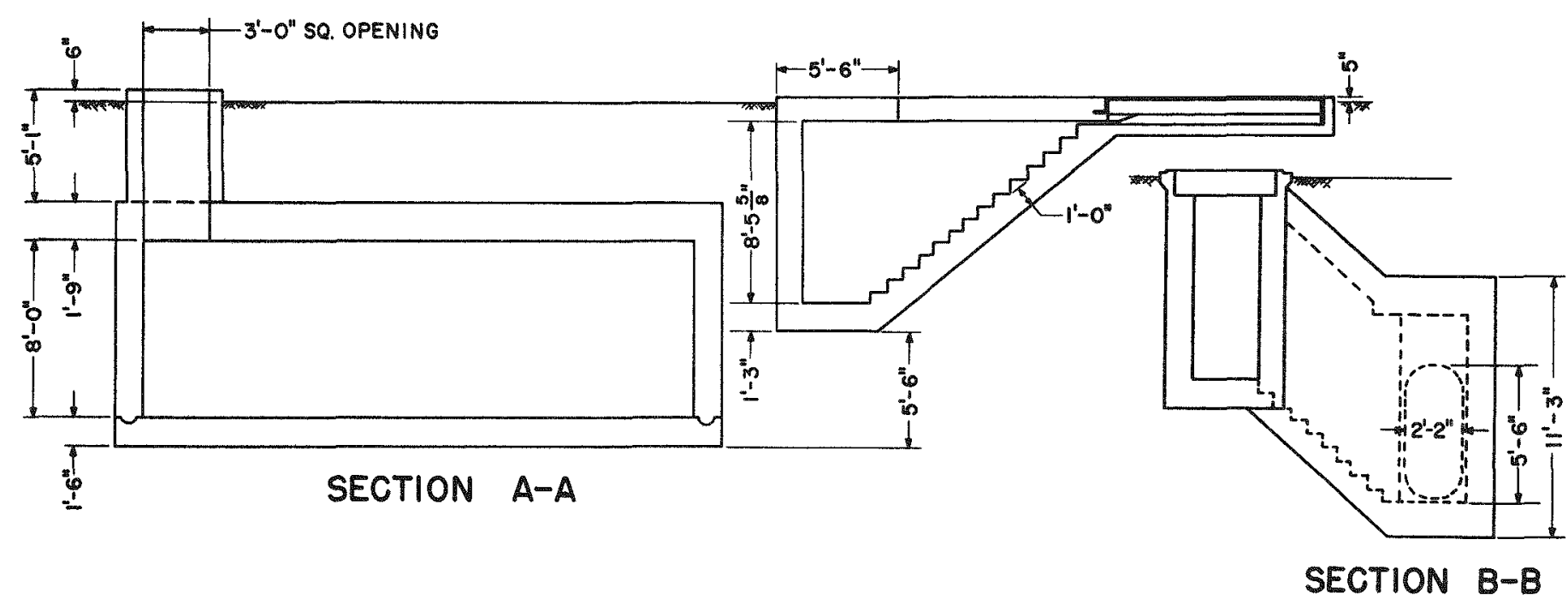

Fig. 1.17 - Plan and section of underground personnel shelter (structural), early shot; Station 1. 

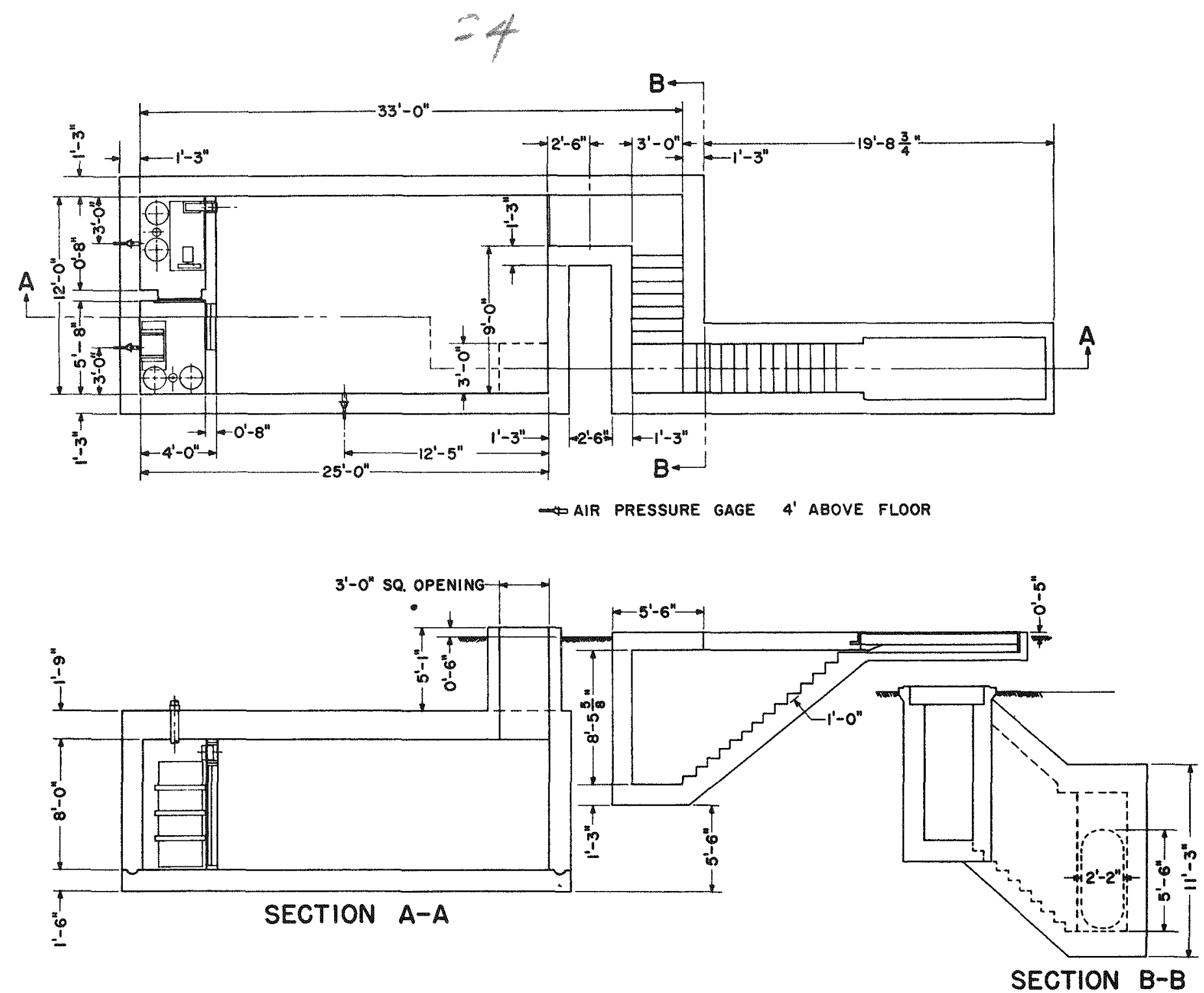

Fig. 1.18 - Plan and section of underground personnel shelter (structura1), open shot: Station $34.3 \mathrm{a}-2$. 

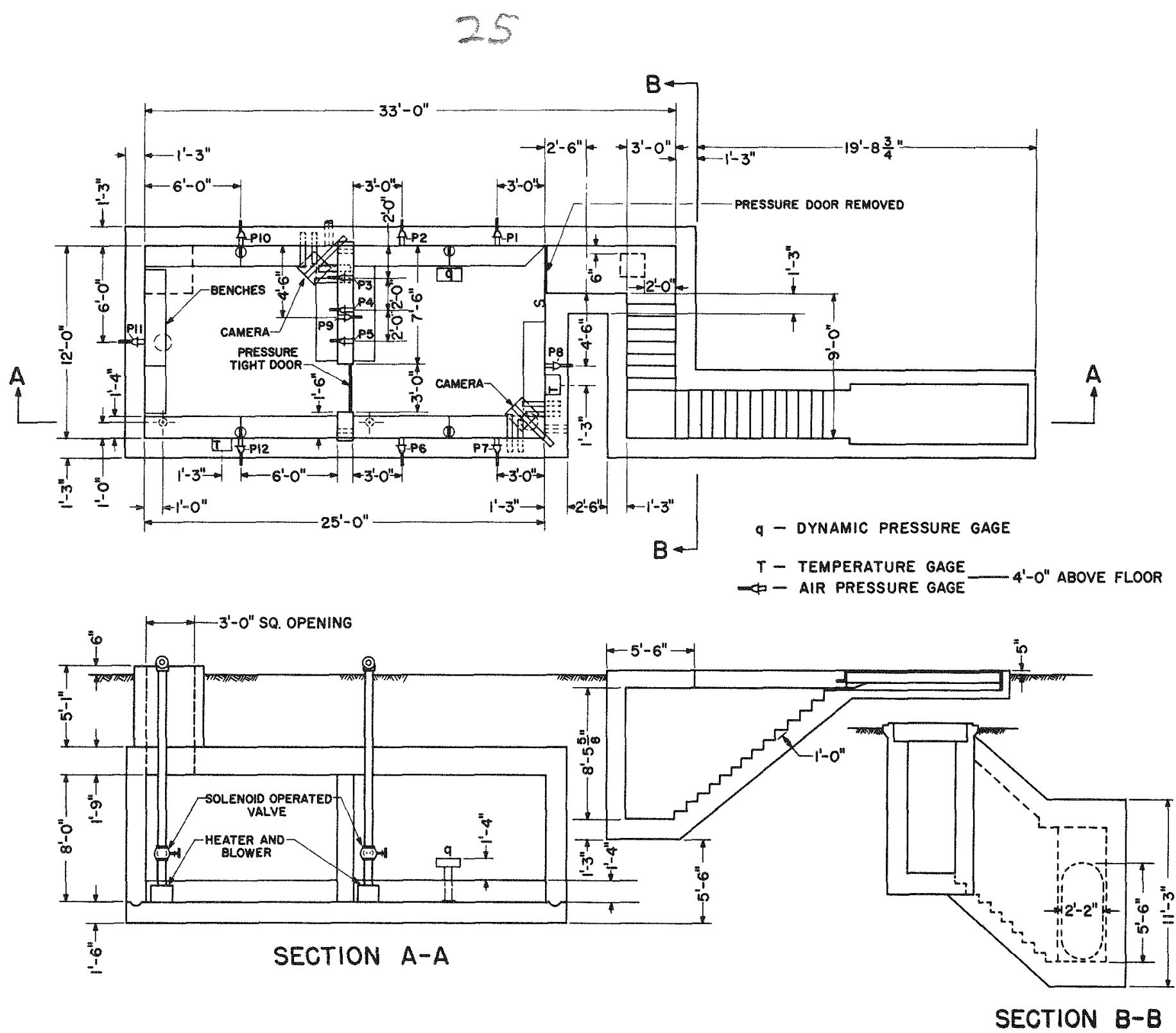

Fig. 1.19-Plan and section of underground personnel shelter (biomedical), early and open shots; Stations 2 and $34.3 \mathrm{~b}-2$. 


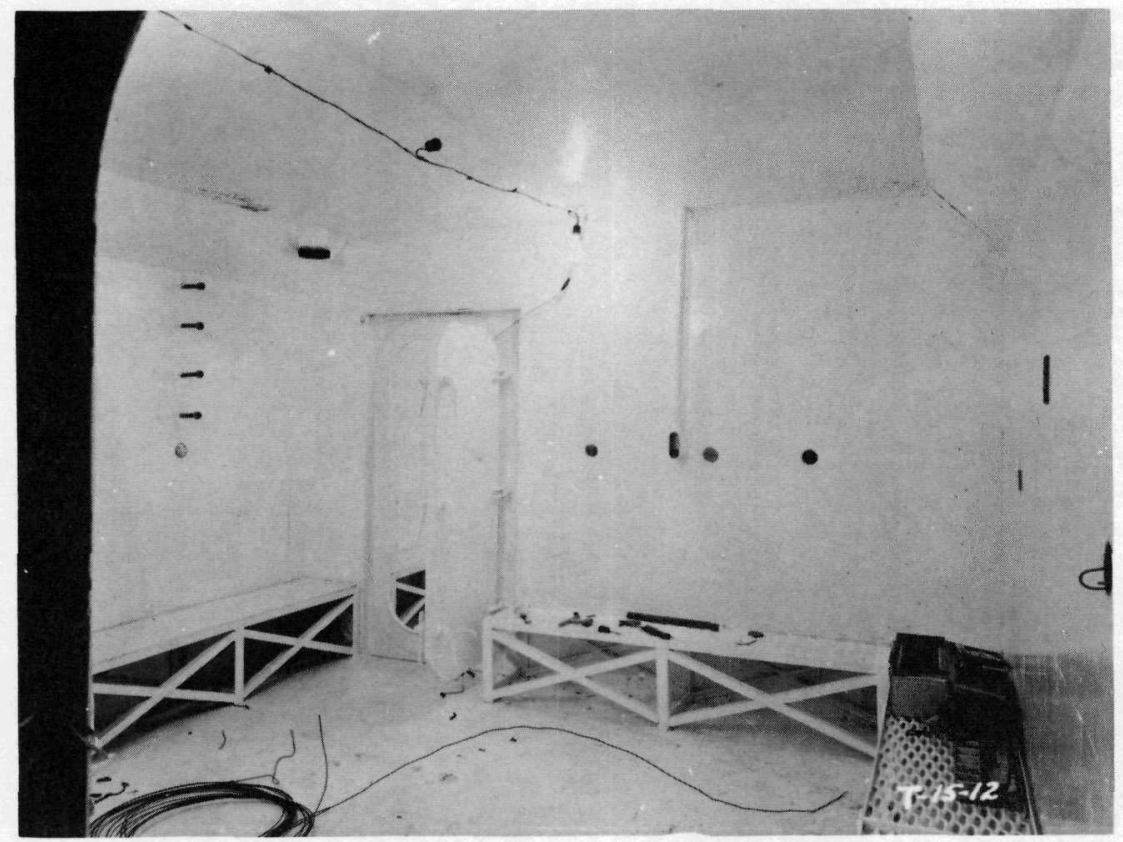

Fig. 1.20-Fast-fill room of partitioned underground personnel shelter; Station 2.

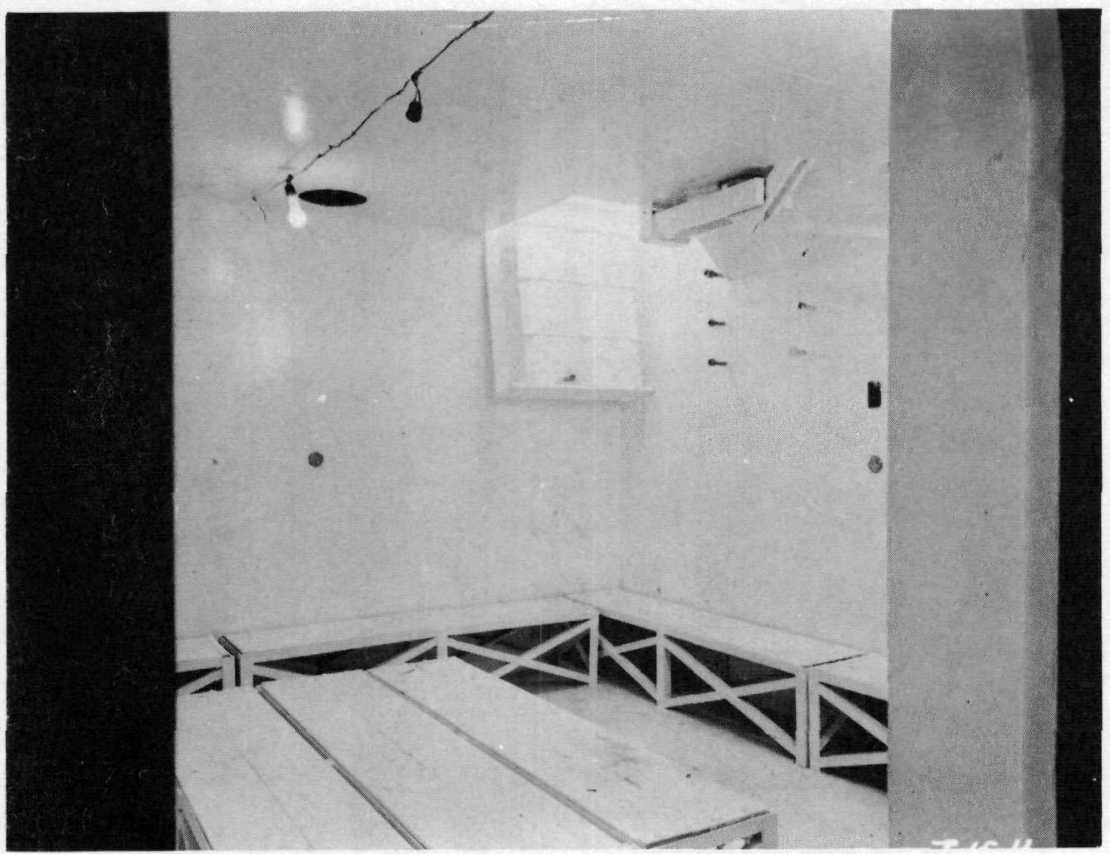

Fig. 1.21 - Slow-fill room of partitioned underground personnel shelter; Station 2. 


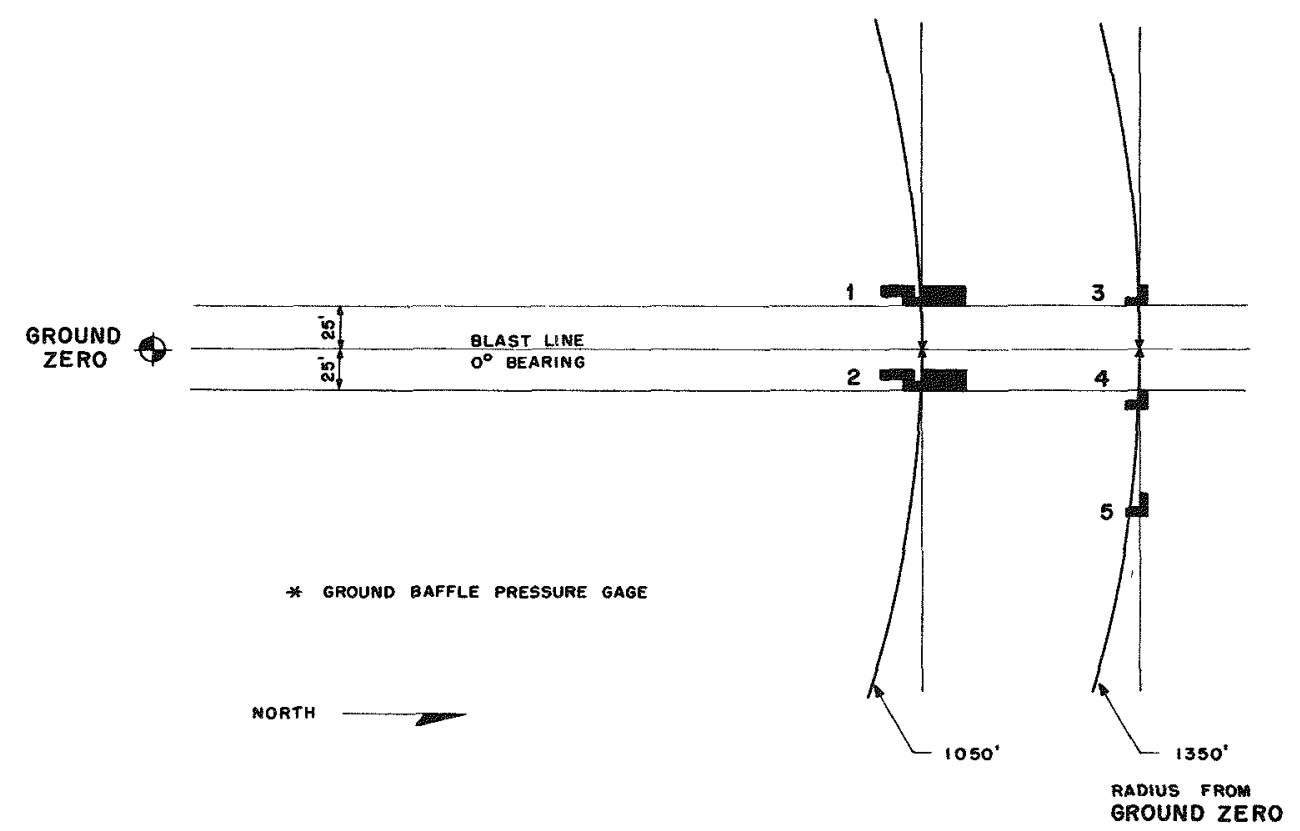

Fig. 1.22-Location of test structures for earlier shot.

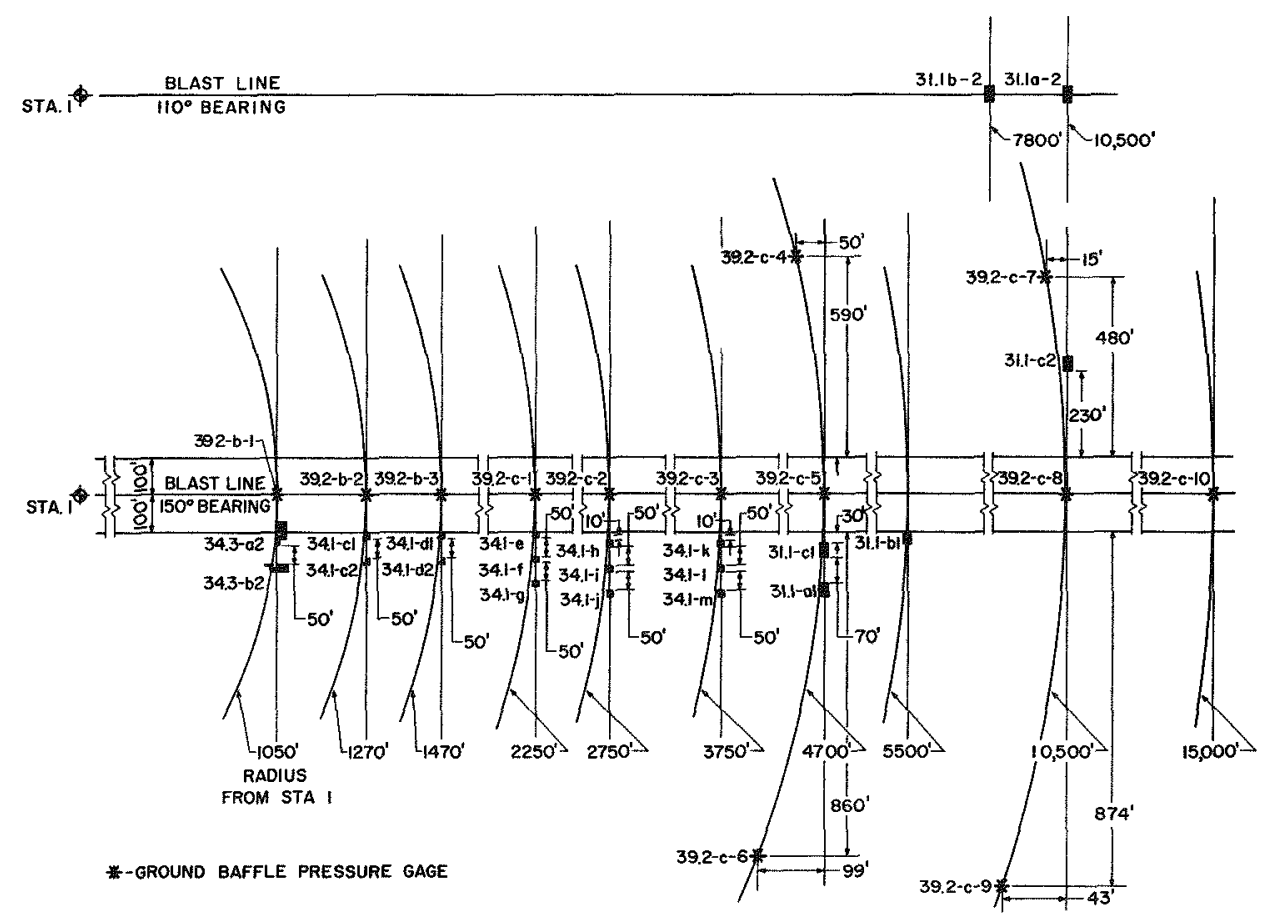

Fig. 1.23-Location of test structures for open shot. 
Table 1.1-SUMMARY OF SHELTERS TESTED

\begin{tabular}{|c|c|c|c|c|c|c|c|}
\hline $\begin{array}{l}\text { Project } \\
\text { No. }\end{array}$ & Structure & Station No. & Shot & $\begin{array}{l}\text { Distance, } \\
\mathrm{ft}\end{array}$ & $\begin{array}{l}\text { Desired } \\
\text { over- } \\
\text { pressure, } \\
\text { psi }\end{array}$ & $\begin{array}{c}\text { Actual } \\
\text { over- } \\
\text { pressure, } \\
\text { psi }\end{array}$ & Instrumentation \\
\hline \multirow[t]{5}{*}{$341 \mathrm{a}$} & $\begin{array}{c}\text { Basemeni lean- } \\
\text { to shelters }\end{array}$ & & & & & & \\
\hline & Brick house & $31,1 \mathrm{a}-1$ & Open & 4,700 & 5 & $4.85-5.1$ & 1 pressure \\
\hline & Brick house & $31.1 \mathrm{a}-2$ & & 10,500 & 1.7 & & \\
\hline & Frame house & $31.1 \mathrm{~b}-1$ & & 5,500 & 4 & & \\
\hline & Frame house & $31.1 \mathrm{~b}-2$ & & 7,800 & 2.5 & & \\
\hline \multirow[t]{5}{*}{$34.1 \mathrm{a}$} & $\begin{array}{c}\text { Basement corner- } \\
\text { room shelter }\end{array}$ & & & & & & \\
\hline & Brick house & $31.1 \mathrm{a}-1$ & Open & 4,700 & 5 & & \\
\hline & Brick house & $31.1 \mathrm{a}-2$ & & 10,500 & 1.7 & & \\
\hline & Frame house & $31.1 \mathrm{~b}-1$ & & 5,500 & 4 & 3.75 & 1 pressure \\
\hline & Frame house & $31.1 \mathrm{~b}-2$ & & 7,800 & 2.5 & & \\
\hline \multirow[t]{3}{*}{$34.1 \mathrm{a}$} & $\begin{array}{l}\text { Basement rein- } \\
\text { forced concrete }\end{array}$ & & & & & & \\
\hline & Frame house & $311 \mathrm{~b}-1$ & Open & 5,500 & 4 & & \\
\hline & Frame house & $31.1 \mathrm{~b}-2$ & & 7,800 & 2.5 & & \\
\hline \multirow[t]{3}{*}{$34.1 \mathrm{a}$} & $\begin{array}{l}\text { Reinforced-con- } \\
\text { crete bathroom } \\
\text { shelter }\end{array}$ & & & & & & \\
\hline & Rambler house & $31.1 \mathrm{c}-1$ & Open & 4,700 & 5 & $4.85-5.1$ & 1 pressure \\
\hline & Rambler house & $31.1 \mathrm{c}-2$ & & 10,500 & 1.7 & & \\
\hline \multirow{3}{*}{$34.1 \mathrm{~b}$} & Masonry utility & $34.1 \mathrm{~g}$ & Open & 2,250 & 13 & & \\
\hline & type shelters & $34.1 \mathrm{~J}$ & & 2,750 & 10 & & \\
\hline & & $34.1 \mathrm{~m}$ & & 3,750 & 7 & 7.8 & \\
\hline \multirow[t]{3}{*}{$34.1 \mathrm{~b}$} & Reinforced-con- & $34.1 \mathrm{f}$ & Open & 2,250 & 13 & & 1 pressure \\
\hline & crete utılity & 34.11 & & 2,750 & 10 & & 1 pressure \\
\hline & $\begin{array}{l}\text { type shelters } \\
\text { (poured-in-piace) }\end{array}$ & 34.11 & & 3,750 & 7 & 7.8 & 1 pressure \\
\hline \multirow[t]{3}{*}{$34.1 \mathrm{~b}$} & Reinforced-con- & $34.1 \mathrm{e}$ & Open & 2,250 & 13 & & \\
\hline & crete utulity & $34.1 \mathrm{~h}$ & & 2,750 & 10 & & \\
\hline & $\begin{array}{l}\text { type shelters } \\
\text { (precast) }\end{array}$ & $34.1 \mathrm{k}$ & & 3,750 & 7 & 7.8 & \\
\hline \multirow[t]{8}{*}{$34.1 \mathrm{~b}$} & $\begin{array}{c}\text { Basement exit } \\
\text { shelters }\end{array}$ & & & & & & \\
\hline & Closed & 3 & Early & 1,350 & 45 & & 2 pressure \\
\hline & Partly open & 4 & & 1,350 & 45 & & 2 pressure \\
\hline & Open & 5 & & 1,350 & 45 & & 2 pressure \\
\hline & Closed & $34.1 \mathrm{c}-1$ & Open & 1,270 & 55 & & 1 pressure \\
\hline & Open & $34.1 \mathrm{c}-2$ & & 1,270 & $\mathbf{5 5}$ & & 1 pressure \\
\hline & Closed & $34.1 \mathrm{~d}-1$ & & 1,470 & 35 & & 1 pressure \\
\hline & Open & $34.1 \mathrm{~d}-2$ & & 1,470 & 35 & & 1 pressure \\
\hline \multirow[t]{5}{*}{34.3} & Group shelters & & & & & & \\
\hline & Structural & 1 & Early & 1,050 & & & $\begin{array}{l}3 \text { pressure, } \\
1 \text { noise }\end{array}$ \\
\hline & Bromedical & 2 & Early & 1,050 & & & $\begin{array}{l}12 \text { pressure, } \\
1 \text { noise, } \\
2 \text { temperature, } \\
1 \text { dynamic } \\
\text { pressure }\end{array}$ \\
\hline & Structural & $34.3 \mathrm{a}-2$ & Open & 1,050 & & & $\begin{array}{l}3 \text { pressure, } \\
1 \text { noise, } \\
1 \text { acceleration }\end{array}$ \\
\hline & Biomedical & $34.3 b-2$ & Open & 1,050 & & & $\begin{array}{l}12 \text { pressure, } \\
1 \text { noise, } \\
2 \text { temperature, } \\
1 \text { dynamic } \\
\text { pressure }\end{array}$ \\
\hline \multirow[t]{11}{*}{34.3} & Blast line & & Early & 1,050 & & & 1 pressure \\
\hline & & & & 1,350 & & & 1 pressure \\
\hline & & & Open & 1,050 & & & 1 pressure \\
\hline & & & & 1,270 & & & 1 pressure \\
\hline & & & & 1,470 & & & 2 pressure \\
\hline & & & & 2,250 & & & 1 pressure \\
\hline & & & & 2,750 & 10 & & 1 pressure \\
\hline & & & & 3,750 & 7 & 7.8 & 1 pressure \\
\hline & & & & 4,700 & 5 & $4.85-5.1$ & 3 pressure \\
\hline & & & & 10,500 & 1.7 & $1.7-2.1$ & 3 pressure \\
\hline & & & & 15,000 & 1 & 1.26 & 1 pressure \\
\hline
\end{tabular}


CHAPTER 2

\section{NUCLEAR RADIATION PENETRATION}

\subsection{RADIATION DETECTORS}

Gamma radiation was measured with film dosimeters developed by the National Bureau of Standards. ${ }^{1}$ Each dosimeter contained five film types of overlapping ranges. Where radiation intensity was expected to be high, low-range film was replaced with very high range film.

Gold, sulfur, germanium, ${ }^{2}$ and chemical neutron ${ }^{3}$ threshold detectors were used. Gold detectors give an index of the number of neutrons per square centimeter in that portion of the energy spectrum up to $4 \mathrm{ev}$. Sulfur detectors range above $3 \mathrm{Mev}$. Germanium detectors cover the range above $1000 \mathrm{ev}$, with readings based on the permanent change in electrical conductivity of germanium caused by a neutron flux. Single-phase chemical dosimeters have a greater sensitivity to fast neutrons $(0.5$ to $8.0 \mathrm{Mev})$ than do two-phase types. Hence, if both types of chemical dosimeters are irradiated by a mixture of fast neutrons and gammas, either radiation can be estimated with reasonable accuracy. ${ }^{3}$

For locations and readings of dosimeters placed in the shelters, see Figs. 2.6 through 2.13 and Tables 2.2 through 2.12. Neutron measurements were not made in utility or indoor family type shelters.

\subsection{INCIDENT RADIATION}

\subsubsection{Gamma Radiation}

Project 39.6 measured incident gamma radiation, ${ }^{4}$ and values of the dosimeters give a plot of incident gamma radiation vs distance for the open shot. Incident gamma radiation on the open shot was measured along a 90 and a $290^{\circ}$ line; the shelters were located on a $150^{\circ}$ line. Because the direction of fall-out was $325^{\circ}$, the radiation measured along the $90^{\circ}$ line is probably more nearly that on the shelter line and hence was used in Fig. 2.1.

\subsubsection{Neutron Radiation}

On open shot, detectors were placed at six distances out to $5500 \mathrm{ft}$. Detectors at the two closer stations were buried $4 \mathrm{in}$., and the last two were at or near ground surface. The solid line in Fig. 2.2 was chosen as the most accurate representation of the fast-neutron radiation. This presupposes that the differences between the solid and dashed lines are due to attenuation through $4 \mathrm{in}$. of soil and that the difference in the third station is due to reduction of fast neutrons by the masonry shelter.

It is interesting to note that for thermal neutrons the flux inside the masonry shelter is consistent with measurements outside the shelters at other distances. It may be that any slow neutrons that were filtered out in passing through the masonry were replaced by an equal num- 


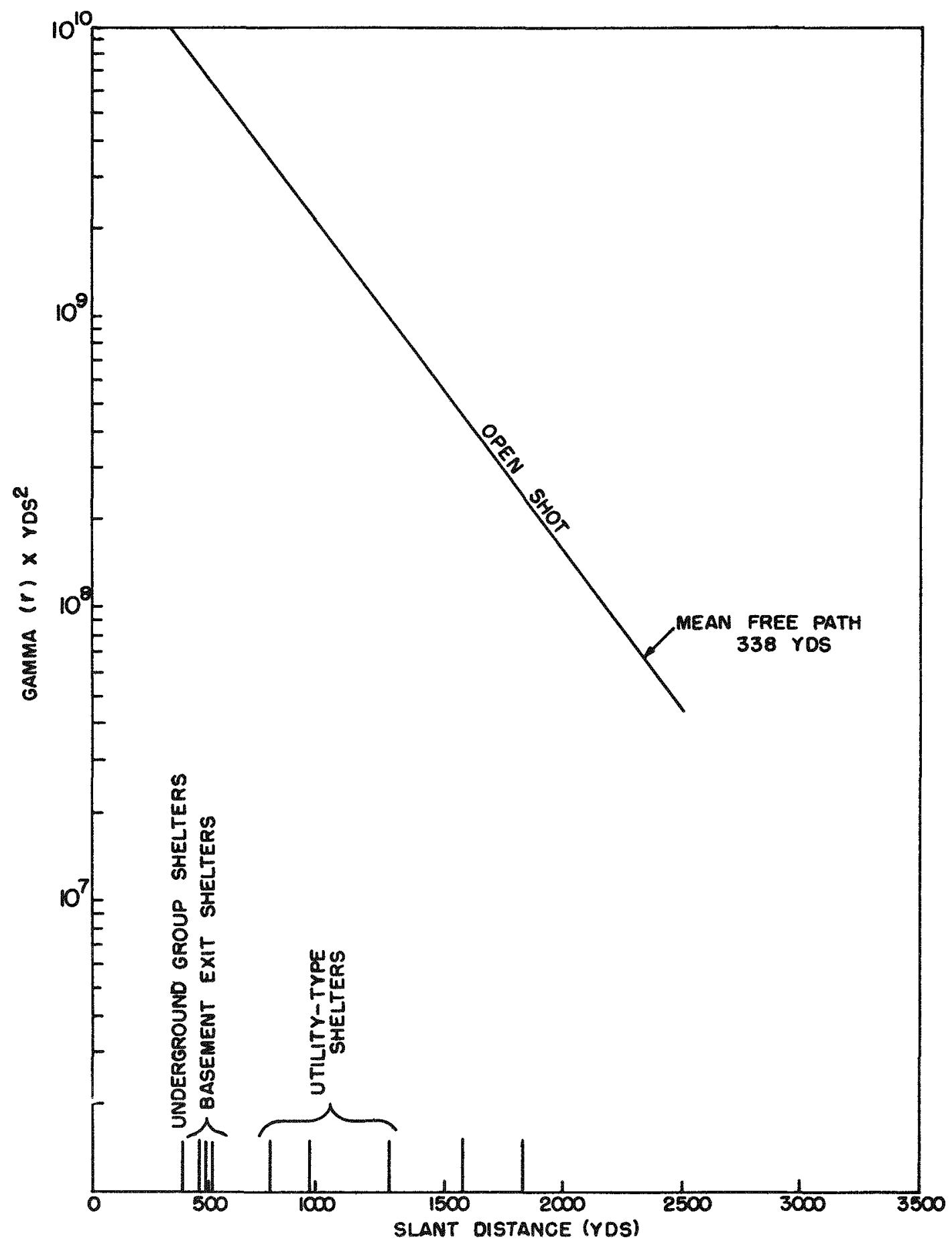

Fig. 2.1 - Incident gamma radiation vs distance. 


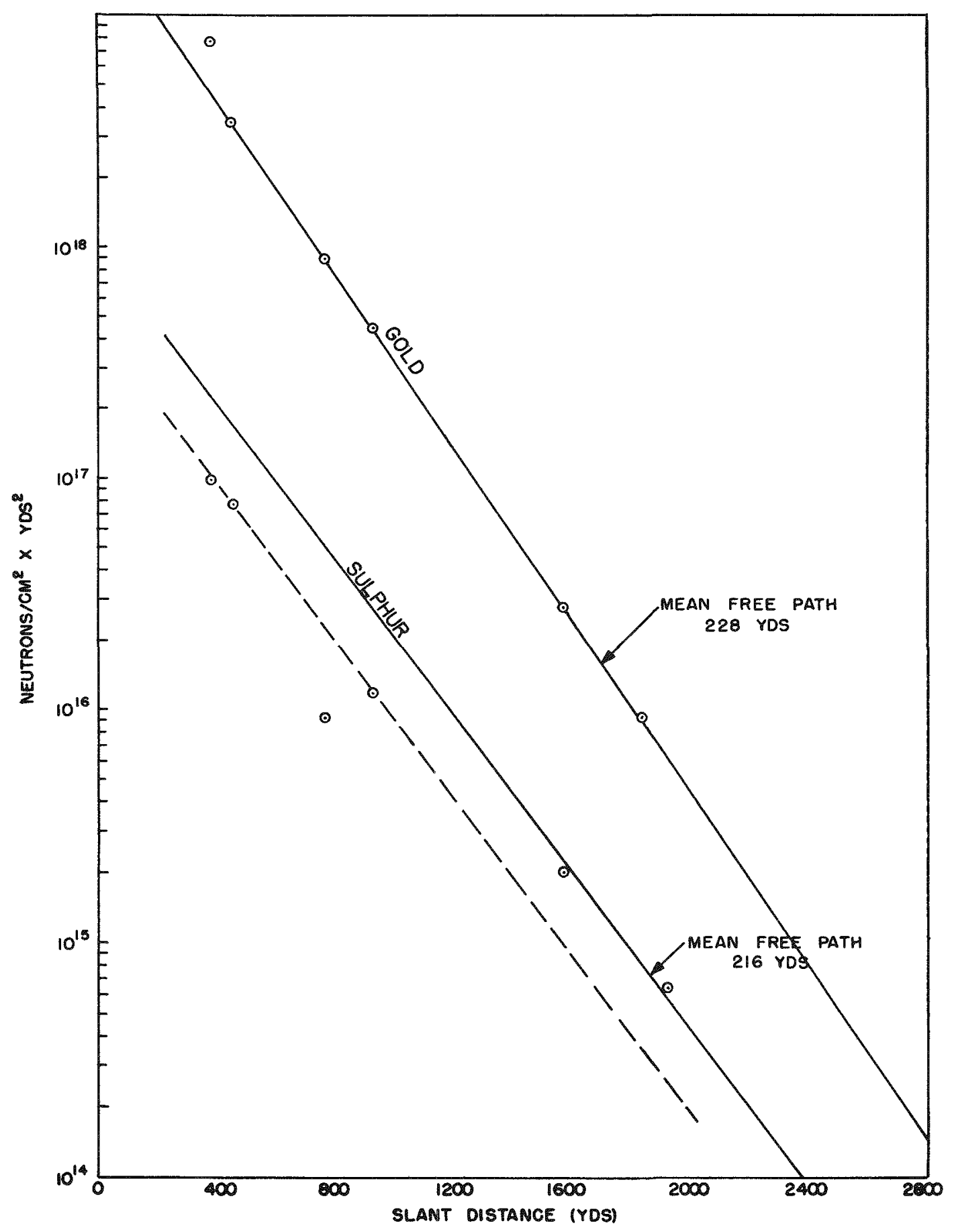

Fig. 2.2-Incident neutron radiation, open shot. 
ber degraded from those starting through at higher energies or that some of those which penetrated the shelter bounced around so that they had more than one chance to be captured by the detector.

\subsection{UNDERGROUND PERSONNEL SHELTER (STRUCTURAL)}

Open Shot (Station $34.3 \mathrm{a}-2$ )

Gamma film dosimeters were recovered at $\mathrm{H}+10 \mathrm{hr}$, and therefore the readings (Fig. 2.3) show total gamma dosage for $10 \mathrm{hr}$ plus the radiation the dosimeters recorded while being removed from the area. Since the minimum reading is $1.0 \mathrm{r}$, no more could have been received during recovery, and the amount was probably much less.

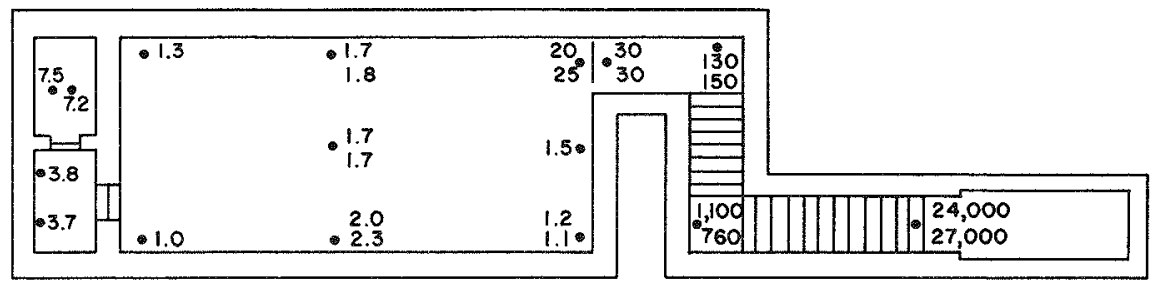

Fig. 2.3-Gamma radiation (in roentgens) in underground personnel shelter (structural), open shot; Station $34.3 \mathrm{a}-2,1050 \mathrm{ft}$.

The ratio of the gamma radiation inside the closed shelters on the two shots was quite different from the ratio of their incident gamma radiations. Although gamma-radiation levels inside the shelters were low on both shots, it would be interesting to know whether the difference inside is related to the magnitude of the incident radiations or whether the dosimeters were merely reading a contribution from thermal neutrons inside one of the shelters. It is reported that the film dosimeter records $4 \times 10^{9}$ thermal neutrons as $1 \mathrm{r}$ (of $\mathrm{Co}^{60}$ gamma rays). ${ }^{5}$ Thermal-neutron flux inside these shelters was below this value $\left(4 \times 10^{8}\right.$ was the highest), but, since gamma-radiation levels were always below $3 \mathrm{r}$, it is possible that this small flux could have made a fractional contribution which could account for the increase.

Three pairs of neutron detectors were placed in this shelter. The sulfur readings were $2 \times 10^{6}$ neutrons $/ \mathrm{cm}^{2}$ at the west (entrance) end of the main room, $2.94 \times 10^{7}$ at the center, and $4.01 \times 10^{8}$ at the east end. Gold readings were $7.75 \times 10^{8}, 8.85 \times 10^{8}$, and $2.33 \times 10^{8}$ at the same locations. ${ }^{a}$

Readings of sulfur detectors are particularly interesting since a layer of boron-containing colemanite was spread on the ground surface above the west half of the main room but not over the east half. Detectors placed 4 in. under the colemanite did not show any noticeable reduction in the fast-neutron flux, but they showed a reduction of the thermal-neutron flux to about one-half that where there was no colemanite. The reduction of fast neutrons inside the shelter in relation to the placement of colemanite is probably only coincidental.

\subsection{UNDERGROUND PERSONNEL SHELTER (BIOMEDICAL)}

Open Shot (Station 34.3 b-2)

Estimated incident radiation (Fig. 2.1) was $57,000 \mathrm{r}$; thus the $50,000 \mathrm{r}$ measured in the stair well (Fig. 2.4) was nearly the full incident dose. The average of three readings at the landing of this shelter was more than five times the average of the readings at the same location on the closed shelter $(34.3 \mathrm{a}-2)$. This is a measure of the shielding effectiveness of the re-

\footnotetext{
${ }^{\mathrm{a}}$ The gold detector at one position was lost.
} 


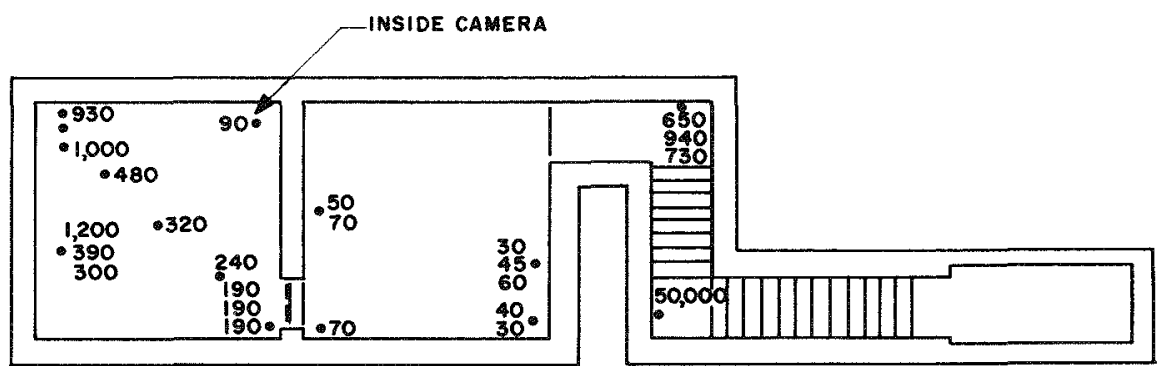

Fig. 2.4-Gamma radiation (in roentgens) in underground personnel shelter (biomedical), open shot; Station $34.3 \mathrm{~b}-2,1050 \mathrm{ft}$.

inforced-concrete sliding door covering the closed shelter. The reading at the foot of the stairs is significantly below that at the landing. Readings inside the fast-fill side varied from 30 to $70 \mathrm{r}$.

Gamma-radiation intensity in the slow-fill side varied from about $1000 \mathrm{r}$ directly under the escape hatch to $190 \mathrm{r}$ at the diagonally opposite corner. The radiation gradient in this chamber plus the generally higher level of radiation when compared with the fast-fill chamber can be attributed to the amount of radiation scatter from the escape-hatch opening.

Both fast- and slow-neutron fluxes were greater immediately below the open escape hatch of the slow-fill chamber than at the foot of the entrance stairs, and the slow-neutron flux was greater by a larger factor than the fast-neutron flux.

\subsection{BASEMENT EXIT SHELTERS}

Open Shot (Stations $34.1 \mathrm{c}-1, \mathrm{c}-2, \mathrm{~d}-1, \mathrm{~d}-2$ )

Incident radiation is estimated (Fig. 2.1) to be $35,000 \mathrm{r}$ for shelters at $1270 \mathrm{ft}$ and $23,500 \mathrm{r}$ for those at $1470 \mathrm{ft}$. Gamma radiation was attenuated toward the closed end of the shelters (Fig. 2.5). It is shown in Fig. 2.5 that the doors remained in place long enough to keep out some of the contaminated materials so that the general radiation level in the closed shelters was onehalf or one-third that in the open shelters.

Neutron detectors show a lower neutron flux inside the closed shelters than inside the open shelters.

\subsection{UTILITY TYPE SHELTERS}

Open Shot (Stations $34.1 \mathrm{c}$ to $\mathrm{m}$ )

Shelters located at 2250,2750 , and $3750 \mathrm{ft}$ were subjected to an estimated (Fig. 2.1) incident gamma radiation of 5750,2600 , and $630 \mathrm{r}$, respectively. For each, the average radiation (average of all film packets) inside each shelter showed gamma radiation to be one-half to onethird that outside.

Program 32 placed neutron detectors only in the masonry block shelter, which was destroyed. As pointed out earlier, thermal neutrons measured by the gold detector were the same as would have been expected outside, whereas fast neutrons were only one-fifth of those to be expected outside (Fig. 2.2).

\subsection{INDOOR FAMILY TYPE SHELTERS}

\section{Open Shot}

The averages of gamma-radiation measurements inside the shelters and incident radiation estimated from Fig. 2.1 are shown in Table 2.1. 


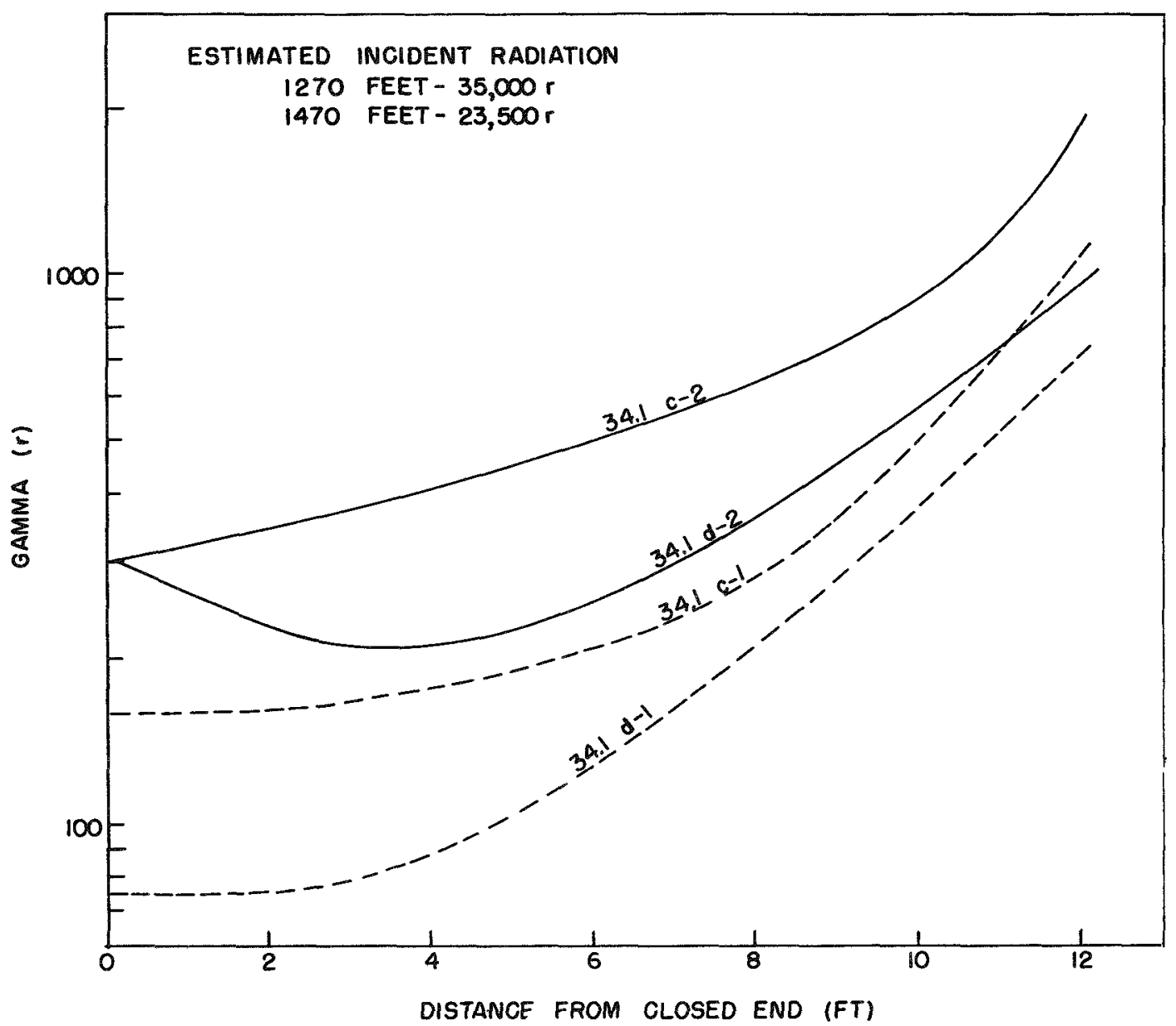

Fig. 2.5- Gamma radiation in basement exit shelters, open shot; Stations $34.1 \mathrm{c}-1$ and $c-2$, $1270 \mathrm{ft}$ : Stations $34.1 \mathrm{~d}-1$ and $\mathrm{d}-2,1470 \mathrm{ft}$. 
Table 2.1-AVERAGE GAMMA RADIATION INSIDE FAMILY TYPE SHELTERS

\begin{tabular}{cccccc}
\hline $\begin{array}{c}\text { Ground } \\
\text { distance, } \\
\mathrm{ft}\end{array}$ & $\begin{array}{c}\text { Estimated } \\
\text { incident } \\
\text { radiation, } \\
\mathrm{r}\end{array}$ & $\begin{array}{c}\text { Basement } \\
\text { lean-to, }\end{array}$ & $\begin{array}{c}\text { Basement } \\
\text { corner room, }\end{array}$ & $\begin{array}{c}\text { Basement } \\
\text { concrete room, } \\
\mathrm{r}\end{array}$ & $\begin{array}{c}\text { Reinforced- } \\
\text { concrete } \\
\text { bathroom, } \\
\mathrm{r}\end{array}$ \\
\hline 4,700 & 180 & 6.7 & 28.00 & & 51.00 \\
5,500 & 70 & 2.48 & 21.00 & 1.77 & \\
7,800 & 11 & 0.67 & 1.22 & 0.20 & \\
10,500 & 0.3 & 0.10 & 0.13 & & 0.24 \\
\hline
\end{tabular}

\section{REFERENCES}

1. M. Ehrlich, Delayed Gamma-ray Measurements: Film Dosimeter Measurements, Operation Greenhouse Report, WT-81, May 1952.

2. B. Cassen et al., Measurement and Permanent Recording of Fast Neutrons by Effects on Semiconductors, Operation Teapot Report, WT-1170.

3. G. V. Taplin et al., Measurement of Initial and Residual Radiations by Chemical Methods, Operation Teapot Report, ITR-1171 (to be superseded by WT-1171).

4. L. J. Deal, Gamma and Neutron Radiation Measurements, Operation Teapot Report, ITR-1174 (to be superseded by WT-1174).

5. P. S. Harris, Physical Measurement of Neutron and Gamma Radiation Dose from High Neutron Yield Weapons and Correlation of Dose with Biological Effect, Operation Teapot Report, ITR-1167 (to be superseded by WT-1167). 
Table 2.2-UNDERGROUND PERSONNEL SHELTER (STRUCTURAL)

Open shot, Station $34.3 \mathrm{a}-2$ (1050 ft)

\begin{tabular}{|c|c|c|c|c|}
\hline \multicolumn{5}{|c|}{ Film dosimeters } \\
\hline Pt. & \multicolumn{2}{|c|}{ Location } & er No. ${ }^{a}$ & Reading, $\mathbf{r}$ \\
\hline 1 & \multicolumn{2}{|c|}{ Center of top riser } & $1-\mathrm{H}$ & 24,000 \\
\hline 1 & \multicolumn{2}{|c|}{ Center of top riser } & $2-\mathrm{H}$ & 27,000 \\
\hline 2 & \multicolumn{2}{|c|}{$1 \mathrm{ft}$ above floor slab } & $3-\mathrm{H}$ & 1,100 \\
\hline 2 & \multicolumn{2}{|c|}{$4 \mathrm{ft}$ above floor slab } & $4-\mathrm{H}$ & 760 \\
\hline $\mathbf{3}$ & \multicolumn{2}{|c|}{$1 \mathrm{ft}$ above floor slab } & 5-H & 130 \\
\hline 3 & \multicolumn{2}{|c|}{$4 \mathrm{ft}$ above floor slab } & $6-\mathrm{H}$ & 150 \\
\hline 4 & \multicolumn{2}{|c|}{ Mid-point of door, outside } & & 30 \\
\hline 4 & \multicolumn{2}{|c|}{ Mid-point of door, outside } & & 30 \\
\hline 5 & \multicolumn{2}{|c|}{ Mid-point of door, inside } & & 20 \\
\hline 5 & \multicolumn{2}{|c|}{ Mid-point of door, inside } & & 25 \\
\hline 6 & \multicolumn{2}{|c|}{$4 \mathrm{ft}$ above floor slab } & & 1.3 \\
\hline 7 & \multicolumn{2}{|c|}{$4 \mathrm{ft}$ above floor slab } & & 2.0 \\
\hline 7 & \multicolumn{2}{|c|}{$4 \mathrm{ft}$ above floor slab } & & 2.3 \\
\hline 8 & \multicolumn{2}{|c|}{$4 \mathrm{ft}$ above floor slab } & & 1.0 \\
\hline 9 & \multicolumn{2}{|c|}{$\begin{array}{l}4 \mathrm{ft} \text { above floor slab } \\
\text { On floor slab directly under }\end{array}$} & & 1.2 \\
\hline $\mathbf{9}$ & \multicolumn{2}{|c|}{$\begin{array}{l}\text { On floor slab directly under } \\
\text { escape-hatch mid-point }\end{array}$} & & 1.1 \\
\hline 10 & \multicolumn{2}{|c|}{$4 \mathrm{ft}$ above floor slab } & & 1.8 \\
\hline 10 & \multicolumn{2}{|c|}{$4 \mathrm{ft}$ above floor slab } & & 1.7 \\
\hline 11 & \multicolumn{2}{|c|}{ At roof slab } & & 1.7 \\
\hline 11 & \multicolumn{2}{|l|}{ On floor slab } & & 1.7 \\
\hline 12 & \multicolumn{2}{|c|}{ Mid-point of wall } & & 1.5 \\
\hline 13 & \multicolumn{2}{|c|}{$\begin{array}{l}5 \mathrm{ft} \text { above floor slab, } 2 \mathrm{ft} \text { in from } \\
\text { side wall }\end{array}$} & & 3.7 \\
\hline 14 & \multicolumn{3}{|c|}{$5 \mathrm{ft}$ above floor slab, $2 \mathrm{ft}$ in from } & 3.8 \\
\hline 15 & On top of filter & & & 7.5 \\
\hline 16 & On top of filter & & & 7.2 \\
\hline & & Neutron detectors & & \\
\hline Pt. & Location & Type & No. & Reading \\
\hline 17 & At floor slab & Sulfur & 157 & $4.01 \times 10^{8}$ \\
\hline 17 & At floor slab & Gold & $557-558$ & Lost \\
\hline 10 & At floor slab & Chemical (sungle phase) & 12 & \\
\hline 10 & At floor slab & Chemical (double phase) & 23 & \\
\hline 10 & At floor slab & Sulfur & 150 & $2.94 \times 10^{7}$ \\
\hline 10 & At floor slab & Gold & $623-624$ & $2.33 \times 10^{8}$ \\
\hline 11 & At floor slab & Chemical (single phase) & 13 & \\
\hline 11 & At floor slab & Chemical (double phase) & 25 & \\
\hline 18 & At floor slab & Sulfur & 154 & $<2 \times 10^{6}$ \\
\hline 18 & At floor slab & Gold & $549-550$ & $7.75 \times 10^{8}$ \\
\hline 18 & At floor slab & Chemical (single phase) & 10 & \\
\hline 18 & At floor slab & Chemical (double phase) & 22 & \\
\hline
\end{tabular}

"High-range dosimeters are indicated by an " $\mathrm{H}$ " following the dosimeter number.

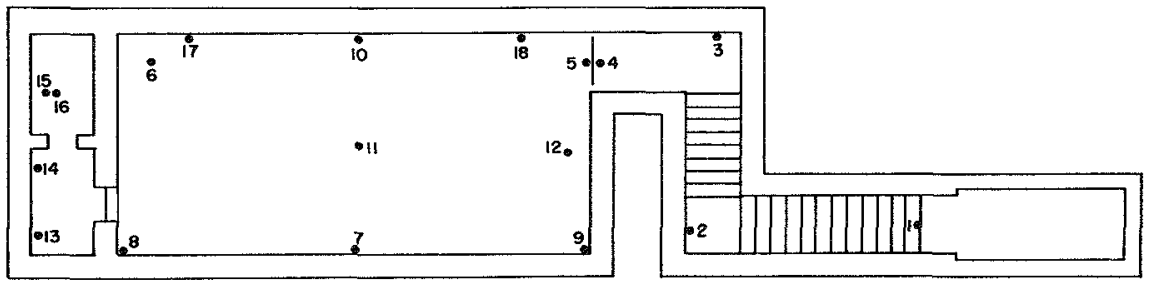

Fig. 2.6- Film dosimeter and neutron detector locations in underground personnel shelter (structural), open shot; Station $34.3 \mathrm{a}-2,1050 \mathrm{ft}$. 
Table 2.3 - UNDERGROUND PERSONNEL SHELTER (BIOMEDICAL)

Open shot, Station $34.3 \mathrm{~b}-2$ (1050 ft)

\begin{tabular}{|c|c|c|c|}
\hline \multicolumn{4}{|c|}{ Film dosimeters } \\
\hline Pt. & Location & Dosimeter No. ${ }^{a}$ & Reading, $r$ \\
\hline 1 & Intersection of roof and wall & $45827-\mathrm{H}$ & Lost \\
\hline 1 & $4 \mathrm{ft}$ above floor & $45828-\mathrm{H}$ & Lost \\
\hline 1 & Intersection of wall and floor & $45829-\mathrm{H}$ & 50,000 \\
\hline 2 & Intersection of roof and wall & $45830-\mathrm{H}$ & 650 \\
\hline 2 & $4 \mathrm{ft}$ above floor & 42490 & 940 \\
\hline 2 & Intersection of wall and floor & 42831 & 730 \\
\hline 3 & Under bench & 42832 & 30 \\
\hline 3 & Under bench & 42833 & 45 \\
\hline 3 & Under bench & 42834 & 60 \\
\hline 4 & On camera mount, inside & 42835 & 40 \\
\hline 4 & On camera mount, outside & 42836 & 30 \\
\hline 5 & Under seat & 42837 & 50 \\
\hline 5 & Under seat & 42838 & 70 \\
\hline 6 & On vent pipe & 42839 & 70 \\
\hline 6 & On vent pipe & 42840 & Lost \\
\hline 7 & At roof & 42891 & 480 \\
\hline 8 & At roof & 42892 & 320 \\
\hline 9 & At roof & 42893 & 240 \\
\hline 10 & At floor 6 in. from side wall & 42894 & 930 \\
\hline 11 & At floor $1 \mathrm{ft} 6$ in. from side wall & 42895 & Lost \\
\hline 12 & At floor $2 \mathrm{ft} 6 \mathrm{in}$. from side wall & 42896 & 1,000 \\
\hline 13 & Under bench & 42897 & 1,200 \\
\hline 13 & Under bench & 42898 & 390 \\
\hline 13 & Under bench & 42899 & 300 \\
\hline 14 & Intersection of roof and wall & 42900 & 190 \\
\hline 14 & $3 \mathrm{ft} 6$ in. above floor & 42901 & 190 \\
\hline 14 & $1 \mathrm{ft} 0$ in. above floor & 42902 & 190 \\
\hline 15 & Camera mount, inside & 43900 & 90 \\
\hline 15 & Camera mount, outside & 43927 & Lost \\
\hline \multicolumn{4}{|c|}{ Neutron detectors } \\
\hline Pt. & Location & No. & Reading \\
\hline 1 & $\begin{array}{l}\text { Upper part of } \\
\text { entry, south } \\
\text { wall }\end{array}$ & 290 & $b$ \\
\hline 1 & $\begin{array}{l}\text { Upper part of } \\
\text { entry, south } \\
\text { wall }\end{array}$ & 291 & $b$ \\
\hline 1 & $\begin{array}{l}\text { Upper part of } \\
\text { entry, south } \\
\text { wall }\end{array}$ & 292 & b \\
\hline 1 & $\begin{array}{l}\text { Upper part of } \\
\text { entry, south } \\
\text { wall }\end{array}$ & 293 & $\mathrm{~b}$ \\
\hline 1 & $\begin{array}{l}\text { Upper part of } \\
\text { entry, south } \\
\text { wall }\end{array}$ & 294 & $\mathrm{~b}$ \\
\hline 2 & $\begin{array}{l}\text { Lower part of } \\
\text { entry, west } \\
\text { wall }\end{array}$ & 285 & b \\
\hline 2 & $\begin{array}{l}\text { Lower part of } \\
\text { entry, west } \\
\text { wall }\end{array}$ & 286 & $\mathbf{b}$ \\
\hline
\end{tabular}


Table $2.3-$ (Continued)

\begin{tabular}{|c|c|c|c|c|}
\hline Pt. & Location & Type & No. & Reading \\
\hline 2 & $\begin{array}{l}\text { Lower part of } \\
\text { entry, west } \\
\text { wall }\end{array}$ & Germanium & 287 & b \\
\hline 2 & $\begin{array}{l}\text { Lower part of } \\
\text { entry, west } \\
\text { wall }\end{array}$ & Germanium & 288 & b \\
\hline 2 & $\begin{array}{l}\text { Intersection of } \\
\text { wall and floor }\end{array}$ & Sulfur & 152 & $1.62 \times 10^{9}$ \\
\hline 2 & $\begin{array}{l}\text { Intersection of } \\
\text { wall and floor }\end{array}$ & Gold & $551-552$ & $1.03 \times 10^{11}$ \\
\hline 3 & $\begin{array}{l}\text { Intersection of } \\
\text { wall and roof }\end{array}$ & Chemical (single phase) & 14 & \\
\hline 3 & $\begin{array}{l}\text { Intersection of } \\
\text { wall and roof }\end{array}$ & Chemical (double phase) & 20 & \\
\hline 3 & Under bench & Chemical (single phase) & 15 & \\
\hline 3 & Under bench & Chemical (double phase) & 24 & \\
\hline 11 & $\begin{array}{l}\text { Below escape } \\
\text { hatch on } \\
\text { floor }\end{array}$ & Chemical (single phase) & 11 & \\
\hline 11 & $\begin{array}{l}\text { Below escape } \\
\text { hatch on } \\
\text { floor }\end{array}$ & Chemical (double phase) & 21 & \\
\hline 11 & $\begin{array}{l}\text { Below escape } \\
\text { hatch on } \\
\text { floor }\end{array}$ & Sulfur & 181 & $5.03 \times 10^{9}$ \\
\hline 11 & $\begin{array}{l}\text { Below escape } \\
\text { hatch on } \\
\text { floor }\end{array}$ & Gold & $621-622$ & $8.56 \times 10^{11}$ \\
\hline 11 & $\begin{array}{l}\text { Below escape } \\
\text { hatch on } \\
\text { floor }\end{array}$ & Germanium & 283 & b \\
\hline 11 & $\begin{array}{l}\text { Below escape } \\
\text { hatch on } \\
\text { floor }\end{array}$ & Germanium & 284 & b \\
\hline
\end{tabular}

"High-range dosimeters are indicated by an " $\mathrm{H}$ " following the dosimeter number.

${ }^{b}$ Results inconclusive (see Report WT-1170, reference 2).

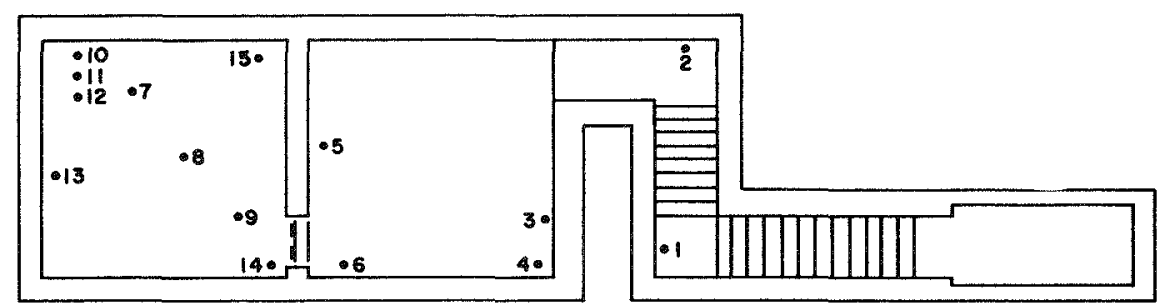

Fig. 2.7-Film dosimeter and neutron detector locations in underground personnel shelter (biomedical), open shot; Station $34.3 \mathrm{~b}-2,1050 \mathrm{ft}$. 


\begin{tabular}{|c|c|c|c|}
\hline \multicolumn{4}{|c|}{ Film dosimeters } \\
\hline Pt. & Location & Dosimeter $\mathrm{No}_{0}{ }^{a}$ & Reading, $\mathbf{r}$ \\
\hline 1 & Center of top riser & $46131-\mathrm{H}$ & 52,000 \\
\hline 1 & Center of top riser & $46132-\mathrm{H}$ & 55,000 \\
\hline 2 & $\begin{array}{l}\text { Undersurface of wooden door between } \\
\text { doors } 2 \text { and } 3\end{array}$ & $45831-\mathrm{H}$ & 70,000 \\
\hline 2 & $\begin{array}{l}\text { Undersurface of wooden door between } \\
\text { doors } 2 \text { and } 3\end{array}$ & $45832-H$ & 56,000 \\
\hline 3 & $\begin{array}{l}\text { Undersurface of wooden door, mid- } \\
\text { point of door } 3\end{array}$ & $45833-\mathrm{H}$ & Lost \\
\hline 3 & $\begin{array}{l}\text { Undersurface of wooden door, mid- } \\
\text { point of door } 3\end{array}$ & $45834-\mathrm{H}$ & Lost \\
\hline 4 & $\begin{array}{l}\text { Intersection of roof and wall } 1 \mathrm{ft} 1 \mathrm{in} \text {. } \\
\text { from far end }\end{array}$ & 42903 & 160 \\
\hline 5 & $\begin{array}{l}\text { Intersection of roof and wall } 2 \mathrm{ft} 1 \text { in. } \\
\text { from far end }\end{array}$ & 42904 & 160 \\
\hline 6 & $\begin{array}{l}\text { Intersection of roof and wall } 3 \mathrm{ft} 1 \mathrm{in.} \\
\text { from far end }\end{array}$ & 42905 & 170 \\
\hline 7 & $\begin{array}{l}\text { Intersection of roof and wall } 4 \mathrm{ft} 1 \mathrm{in} \text {. } \\
\text { from far end }\end{array}$ & 42906 & 190 \\
\hline 8 & $\begin{array}{l}\text { Intersection of roof and wall } 5 \mathrm{ft} 1 \text { in. } \\
\text { from far end }\end{array}$ & 42907 & 220 \\
\hline 9 & $\begin{array}{l}\text { Intersection of roof and wall } 6 \mathrm{ft} 1 \mathrm{in} \text {. } \\
\text { from far end }\end{array}$ & 42908 & 210 \\
\hline 10 & $\begin{array}{l}\text { Intersection of roof and wall } 7 \mathrm{ft} 1 \text { in. } \\
\text { from far end }\end{array}$ & 42909 & 230 \\
\hline 11 & $\begin{array}{l}\text { Intersection of roof and wall } 8 \mathrm{ft} 1 \text { in. } \\
\text { from far end }\end{array}$ & 42910 & 290 \\
\hline 12 & $\begin{array}{l}\text { Intersection of roof and wall } 9 \mathrm{ft} 1 \mathrm{in} . \\
\text { from far end }\end{array}$ & $45835-\mathrm{H}$ & 370 \\
\hline 13 & $\begin{array}{l}\text { Intersection of roof and wall } 10 \mathrm{ft} 1 \text { in. } \\
\text { from far end }\end{array}$ & $45836-\mathrm{H}$ & 650 \\
\hline 14 & $\begin{array}{l}\text { Intersection of roof and wall } 11 \mathrm{ft} 1 \mathrm{in} . \\
\text { from far end }\end{array}$ & $45837-\mathrm{H}$ & 640 \\
\hline 15 & $\begin{array}{l}\text { Intersection of roof and wall } 12 \mathrm{ft} 1 \mathrm{in} \text {. } \\
\text { from far end }\end{array}$ & $45838-\mathrm{H}$ & 1,330 \\
\hline \multicolumn{4}{|c|}{ Neutron detectors } \\
\hline Pt. & Location & No. & Reading \\
\hline 15 & At floor slab & 156 & $3.76 \times 10^{10}$ \\
\hline 15 & At floor slab & $559-560$ & $2.00 \times 10^{12}$ \\
\hline
\end{tabular}

Open shot, Station $34.1 \mathrm{~d}-1$ (1470 ft)

Film dosimeters

Pt.

1

1

2

2

3
At floor slab
Dosimeter No. ${ }^{2}$

45839-H

45840-H

45841- H

45842-H

45843-H
Reading, r

24,000

32,000

Lost

Lost

Lost 
Table 2.4-(Continued)

Pt.

3 Undersurface of wooden door at mid-point of door 2

4

5

6

\begin{tabular}{lllcc} 
Pt. & \multicolumn{3}{c}{ Neutron detectors } \\
& Location & Type & No. & Reading \\
15 & At floor slab & Sulfur & 155 & $1.92 \times 10^{10}$ \\
15 & At floor slab & Gold & $547-548$ & $1.18 \times 10^{12}$ \\
\hline
\end{tabular}

a High-range dosimeters are indicated by an " $\mathrm{H}$ " following the dosimeter number.

bxtrapolated and reading doubtful.

$\begin{array}{cr}\text { Dosimeter No. } & \text { Reading, } \\ 45844-\mathrm{H} & 150^{\mathrm{B}} 00^{\mathrm{b}} \\ 42911 & 75 \\ 42912 & 75 \\ 42913 & 75 \\ 42914 & 90 \\ 42915 & 100 \\ 42916 & 130 \\ 42917 & 170 \\ 42918 & 200 \\ 45845-\mathrm{H} & 290 \\ 45846-\mathrm{H} & 380 \\ 45847-\mathrm{H} & 600 \\ 45848-\mathrm{H} & 560\end{array}$

560
Intersection of roof and wall $1 \mathrm{ft} 1 \mathrm{in}$. from far end

Intersection of roof and wall $2 \mathrm{ft} 1 \mathrm{in}$. from far end

Intersection of roof and wall $3 \mathrm{ft} 1 \mathrm{in}$. from far end

Intersection of roof and wall $4 \mathrm{ft} 1 \mathrm{in}$. from far end

Intersection of roof and wall $5 \mathrm{ft} 1 \mathrm{in}$. from far end

Intersection of roof and wall $6 \mathrm{ft} 1 \mathrm{in}$. from far end

Intersection of roof and wall $7 \mathrm{ft} 1 \mathrm{in}$. from far end

Intersection of roof and wall $8 \mathrm{ft} 1 \mathrm{in}$. from far end.

Intersection of roof and wall $9 \mathrm{ft} 1 \mathrm{in}$.

Intersection of roof and wall $10 \mathrm{ft} 1 \mathrm{in}$. from far end

Intersection of roof and wall $11 \mathrm{ft} 1 \mathrm{in}$. from far end from far end

Neutron detectors

Pt. 


\begin{tabular}{|c|c|c|c|}
\hline \multicolumn{4}{|c|}{ Film dosimeters } \\
\hline Pt. & Location & Dosimeter No. ${ }^{a}$ & Reading, $r$ \\
\hline 1 & Center of top riser & $45849-\mathrm{H}$ & 56,000 \\
\hline 1 & Center of top riser & $45850-\mathrm{H}$ & \\
\hline 4 & $\begin{array}{l}\text { Intersection of roof and wall } 1 \mathrm{ft} 1 \mathrm{in} . \\
\text { from far end }\end{array}$ & 42919 & 310 \\
\hline 5 & $\begin{array}{l}\text { Intersection of roof and wall } 2 \mathrm{ft} 1 \text { in. } \\
\text { from far end }\end{array}$ & 42920 & 370 \\
\hline 6 & $\begin{array}{l}\text { Intersection of roof and wall } 3 \mathrm{ft} 1 \text { in. } \\
\text { from far end }\end{array}$ & 42921 & 370 \\
\hline 7 & $\begin{array}{l}\text { Intersection of roof and wall } 4 \mathrm{ft} 1 \mathrm{in} \text {. } \\
\text { from far end }\end{array}$ & 42922 & 460 \\
\hline 8 & $\begin{array}{l}\text { Intersection of roof and wall } 5 \mathrm{ft} 1 \mathrm{in} \text {. } \\
\text { from far end }\end{array}$ & 42923 & 500 \\
\hline 9 & $\begin{array}{l}\text { Intersection of roof and wall } 6 \mathrm{ft} 1 \text { in. } \\
\text { from far end }\end{array}$ & 42924 & 430 \\
\hline 10 & $\begin{array}{l}\text { Intersection of roof and wall } 7 \mathrm{ft} 1 \mathrm{in} \text {. } \\
\text { from far end }\end{array}$ & 42925 & Lost \\
\hline 11 & $\begin{array}{l}\text { Intersection of roof and wall } 8 \mathrm{ft} 1 \mathrm{in} \text {. } \\
\text { from far end }\end{array}$ & 42926 & 720 \\
\hline 12 & $\begin{array}{l}\text { Intersection of roof and wall } 9 \mathrm{ft} 1 \mathrm{in} \text {. } \\
\text { from far end }\end{array}$ & $45851-\mathrm{H}$ & 730 \\
\hline 13 & $\begin{array}{l}\text { Intersection of roof and wall } 10 \mathrm{ft} 1 \mathrm{in} \text {. } \\
\text { from far end }\end{array}$ & $45852-\mathrm{H}$ & 950 \\
\hline 14 & $\begin{array}{l}\text { Intersection of roof and wall } 11 \mathrm{ft} 1 \text { in. } \\
\text { from far end }\end{array}$ & $45853-\mathrm{H}$ & 1,150 \\
\hline 15 & $\begin{array}{l}\text { Intersection of roof and wall } 12 \mathrm{ft} 1 \mathrm{in} \text {. } \\
\text { from far end }\end{array}$ & $45854-\mathrm{H}$ & Lost \\
\hline \multicolumn{4}{|c|}{ Neutron detectors } \\
\hline Pt. & Location & No. & Reading \\
\hline 15 & At floor slab & 158 & $5.43 \times 10^{10}$ \\
\hline 15 & At flopr slab & $555-556$ & Lost \\
\hline \multicolumn{4}{|c|}{ Open shot, Station $34.1 \mathrm{~d}-2(1470 \mathrm{ft})$} \\
\hline \multicolumn{4}{|c|}{ Film dosimeters } \\
\hline Pt. & Location & Dosimeter No. ${ }^{a}$ & Reading, $\mathbf{r}$ \\
\hline 1 & Center of top riser & $45855-\mathrm{H}$ & 35,000 \\
\hline 1 & Center of top riser & $45856-\mathrm{H}$ & 32,000 \\
\hline 4 & $\begin{array}{l}\text { Intersection of roof and wall } 1 \mathrm{ft} 1 \mathrm{in.} \\
\text { from far end }\end{array}$ & 42928 & 270 \\
\hline 5 & $\begin{array}{l}\text { Intersection of roof and wall } 2 \mathrm{ft} 1 \mathrm{in} \text {. } \\
\text { from far end }\end{array}$ & 42929 & 250 \\
\hline 6 & $\begin{array}{l}\text { Intersection of roof and wall } 3 \mathrm{ft} 1 \text { in. } \\
\text { from far end }\end{array}$ & 42930 & 190 \\
\hline 7 & $\begin{array}{l}\text { Intersection of roof and wall } 4 \mathrm{ft} 1 \mathrm{in} \text {. } \\
\text { from far end }\end{array}$ & 42931 & 220 \\
\hline 8 & $\begin{array}{l}\text { Intersection of roof and wall } 5 \mathrm{ft} 1 \text { in. } \\
\text { from far end }\end{array}$ & 42932 & 220 \\
\hline 9 & $\begin{array}{l}\text { Intersection of roof and wall } 6 \text { it } 1 \text { in. } \\
\text { from far end }\end{array}$ & 42933 & 290 \\
\hline
\end{tabular}


Table 2.5-(Continued)

Pt.

10 Intersection of roof and wall $7 \mathrm{ft} 1 \mathrm{in}$. from far end

11 Intersection of roof and wall $8 \mathrm{ft} 1$ in. from far end

12 Intersection of roof and wall $9 \mathrm{ft} 1$ in. from far end

13 Intersection of roof and wall $10 \mathrm{ft} 1 \mathrm{in.}$ from far end

14 Intersection of roof and wall $11 \mathrm{ft} 1 \mathrm{in}$. from far end

15

Intersection of roof and wall $12 \mathrm{ft} 1 \mathrm{in}$. from far end

Dosimeter No. ${ }^{a}$

42934

42935

45857-H

45858-H

45859-H

$45860-\mathrm{H}$

Neutron detectors

Pt.

Location

At floor slab

At floor slab
Type

Sulfur

Gold
No.

151

553-554
Reading, $r$

270

460

2,100

2,500

730

980

a High-level dosimeters are indicated by an " $\mathrm{H}$ " following the dosimeter number.

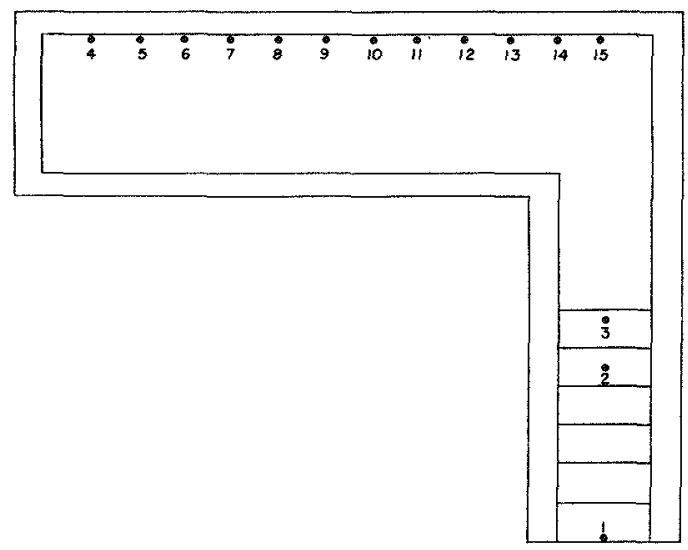

Fig. 2.8- Film dosimeter and neutron detector locations in basement exit shelters, open shot; Stations $34.1 \mathrm{c}-1$ and $\mathrm{c}-2,1270 \mathrm{ft}$; Stations 34.1 $\mathrm{d}-1$ and $\mathrm{d}-2,1470 \mathrm{ft}$. 
Table 2.6 - UTILITY SHE LTER (FILM DOSIMETERS) Open shot, $2250 \mathrm{ft}$

\begin{tabular}{cccc}
\hline Pt. & Location & Dosimeter No. & Reading, $r$ \\
\hline & \multicolumn{1}{c}{ Station 34.1 e, reinforced-concrete precast } \\
1 & Mid-point of blast door (exterior) & 42936 & \\
2 & Mid-point of blast door (nterior) & 42937 & Lost \\
3 & Mid-point of wall & 42938 & Lost \\
4 & Mid-point of wall & 42939 & Lost \\
5 & Mid-point of wall & 42940 & Lost \\
6 & Mid-point of roof, $1 \mathrm{ft} 6$ in. down & 42941 & 3300 \\
6 & Mid-point of roof, 3 ft 0 in. down & 42942 & Lost \\
6 & Mid-point of roof, $4 \mathrm{ft} 6$ in. down & 42943 & Lost \\
6 & Mid-point of roof, $6 \mathrm{ft} 0$ in. down & 42944 & 2450 \\
& & & 2200
\end{tabular}

Station $34.1 \mathrm{f}$, reinforced-concrete poured-in-place

\section{Mid-point of blast door (exterior)}

Mid-point of blast door (interior)

Mid-point of wall

42945

42946

42947

Mid-point of wall

Mid-point of wall

Mid-point of roof, $1 \mathrm{ft} 6 \mathrm{in}$, down

Mid-point of roof, $3 \mathrm{ft} 0$ in.

Mid-point of roof, $4 \mathrm{ft} 6 \mathrm{in}$. down

42948

42949

42950

42950

42951

Mid-point of roof, $6 \mathrm{ft} 0 \mathrm{in}$. down

42953

Station $34.1 \mathrm{~g}$, masonry block

Mid-point of blast door (exterior)

Mid-point of blast door (interior)

Mid-point of wall

Mid-point of wall

Mid-point of wall

Mid-point of roof $1 \mathrm{ft} 6 \mathrm{in}$, dowm

Mid-point of roof 3 ft 0 in down

Mid-point of roof, $4 \mathrm{ft} 6 \mathrm{in}$. down

Mid-point of roof, $6 \mathrm{ft} 0 \mathrm{in}$. down

42955

42956

42957

42958

42959

42961

42962 
Table 2.8 - UTILITY SHELTER (FILM DOSIMETERS) Open shot, $3750 \mathrm{ft}$

\begin{tabular}{cccc}
\hline Pt. & Location & Dosimeter No. & Reading, $r$ \\
\hline \multicolumn{4}{c}{ Station $34.1 \mathrm{k}$, reinforced-concrete precast } \\
1 & Mid-point of blast door (exterior) & 42983 & \\
2 & Mid-point of blast door (interior) & 42984 & 420 \\
3 & Mid-point of wall & 42985 & 270 \\
4 & Mid-point of wall & 42986 & 310 \\
5 & Mid-point of wall & 42987 & 200 \\
6 & Mid-point of roof, $1 \mathrm{ft} 6$ in. down & 42988 & 260 \\
6 & Mid-point of roof, $3 \mathrm{ft} 0 \mathrm{in.}$ down & 42989 & 280 \\
6 & Mid-point of roof, $4 \mathrm{ft} 6 \mathrm{in.}$ down & 42990 & 300 \\
6 & Mid-point of roof, $6 \mathrm{ft} 0$ in. down & 42991 & 300 \\
& & & 300
\end{tabular}

Station 34.1 1, reinforced-concrete poured-in-place

$\begin{array}{lll}\text { Mid-point of blast door (exterior) } & 42992 & 430 \\ \text { Mid-point of blast door (interior) } & 42993 & 220 \\ \text { Mid-point of wall } & 42994 & 320 \\ \text { Mid-point of wall } & 42995 & 200 \\ \text { Mid-point of wall } & 42996 & 280 \\ \text { Mid-point of roof, } 1 \mathrm{ft} 6 \mathrm{in} \text {. down } & 42997 & 280 \\ \text { Mid-point of roof, } 3 \mathrm{ft} 0 \mathrm{in} \text {. down } & 42998 & 320 \\ \text { Mid-point of roof, } 4 \mathrm{ft} 6 \mathrm{in} \text {. down } & 42999 & 290 \\ \text { Mid-point of roof, } 6 \mathrm{ft} 0 \mathrm{in} \text {. down } & 43000 & 290\end{array}$

Station $34.1 \mathrm{~m}$, masonry block

\begin{tabular}{llll}
1 & Mid-point of blast door (exterior) & 43001 & 490 \\
2 & Mid-point of blast door (interior) & 43002 & 290 \\
3 & Mid-point of wall & 43003 & 240 \\
4 & Mid-point of wall & 43004 & 210 \\
5 & Mid-point of wall & 43005 & 210 \\
6 & Mid-point of roof, $1 \mathrm{ft} 6$ in. down & 43006 & 210 \\
6 & Mid-point of roof, $3 \mathrm{ft} 0$ in. down & 43007 & 220 \\
6 & Mid-point of roof, $4 \mathrm{ft} 6$ in. down & 43008 & 220 \\
6 & Mid-point of roof, $6 \mathrm{ft} 0$ in. down & 43009 & 210 \\
\hline
\end{tabular}

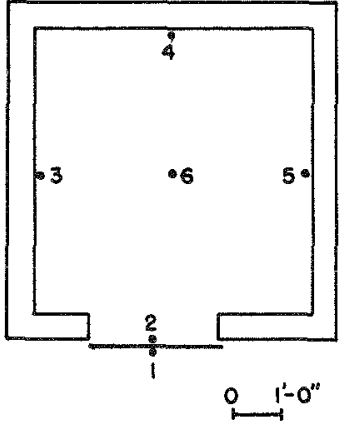

Fig. 2.9-Film dosimeter locations in utility type shelters; Stations 34.1 e to $\mathrm{m}$. 
Table 2.9-REINFORCED-CONCRETE BATHROOM SHELTER (FILM DOSIMETERS)

\begin{tabular}{|c|c|c|c|}
\hline Pt. & Location & Dosimeter No. & Reading, $\mathrm{r}$ \\
\hline \multicolumn{4}{|c|}{ Open shot, Station $31.1 \mathrm{c}-1(4700 \mathrm{ft})$} \\
\hline 1 & Mid-height of door (exterior) & 43976 & Lost \\
\hline 2 & Mid-height of door (interior) & 43977 & 170 \\
\hline 3 & $\begin{array}{l}\text { Intersection of roof and wall, } 1 \mathrm{ft} 0 \mathrm{in} \text {. } \\
\text { from front wall }\end{array}$ & 43978 & 30 \\
\hline 4 & $\begin{array}{l}\text { Intersection of roof and wall, } 3 \mathrm{ft} 6 \mathrm{in} \text {. } \\
\text { from front wall }\end{array}$ & 43979 & 30 \\
\hline 5 & $\begin{array}{l}\text { Intersection of roof and wall, } 6 \mathrm{ft} 0 \mathrm{in} \text {. } \\
\text { from front wall }\end{array}$ & 43980 & 25 \\
\hline 6 & Mid-point of shutter (interior) & 43981 & 35 \\
\hline 7 & Mid-point of floor & 43982 & 50 \\
\hline 7 & Mid-point of roof & 43983 & 13.6 \\
\hline \multicolumn{4}{|c|}{ Open shot, Station $31.1 \mathrm{c}-2(10,500 \mathrm{ft})$} \\
\hline 1 & Mid-height of door (exterior) & 43984 & 0.5 \\
\hline 2 & Mid-height of door (interior) & 43985 & Lost \\
\hline 3 & $\begin{array}{l}\text { Intersection of roof and wall, } 1 \mathrm{ft} 0 \mathrm{in} \text {. } \\
\text { from front wall }\end{array}$ & 43986 & 0.21 \\
\hline 4 & $\begin{array}{l}\text { Intersection of roof and wall, } 3 \mathrm{ft} 6 \text { in. } \\
\text { from front wall }\end{array}$ & 43987 & 0.21 \\
\hline 5 & $\begin{array}{l}\text { Intersection of roof and wall, } 6 \mathrm{ft} 0 \mathrm{in} \text {. } \\
\text { from front wall }\end{array}$ & 43988 & 0.17 \\
\hline 6 & Mid-point of shutter (interior) & 43989 & 0.20 \\
\hline 7 & Mid-point of floor & 43990 & Lost \\
\hline 7 & Mid-point of roof & 43991 & 0.14 \\
\hline
\end{tabular}

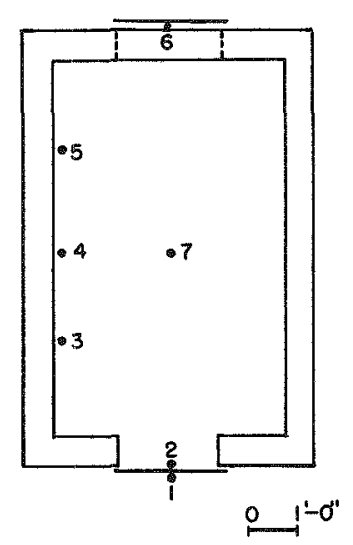

Fig. 2.10- Film dosimeter locations in reinforced-concrete bathroom shelter in rambler houses; Stations $31.1 \mathrm{c}-1$ and c-2. 


\begin{tabular}{|c|c|c|c|}
\hline Pt. & Location & Dosimeter No. & Reading, $r$ \\
\hline \multicolumn{4}{|c|}{ Open shot, Station $31.1 \mathrm{~b}-1$ (5500 ft) } \\
\hline 1 & $\begin{array}{l}\text { Mid-height of end wall along center } \\
\text { line }\end{array}$ & 43943 & 1.0 \\
\hline 2 & $\begin{array}{l}\text { Intersection of roof and wall, } 1 \mathrm{ft} 0 \mathrm{in} \text {. } \\
\text { from rear wall }\end{array}$ & 43944 & 0.95 \\
\hline 3 & $\begin{array}{l}\text { Intersection of roof and wall, } 2 \mathrm{ft} 0 \mathrm{in} \text {. } \\
\text { from rear wall }\end{array}$ & 43945 & 0.95 \\
\hline 4 & $\begin{array}{l}\text { Intersection of roof and wall, } 3 \mathrm{ft} 0 \mathrm{in} \text {. } \\
\text { from rear wall }\end{array}$ & 43946 & 0.95 \\
\hline 5 & $\begin{array}{l}\text { Intersection of roof and wall, } 4 \mathrm{ft} 0 \mathrm{in} \text {. } \\
\text { from rear wall }\end{array}$ & 43947 & 0.95 \\
\hline 6 & $\begin{array}{l}\text { Intersection of roof and wall, } 5 \mathrm{ft} 0 \text { in. } \\
\text { from rear wall }\end{array}$ & 43948 & 1.1 \\
\hline 7 & $\begin{array}{l}\text { Intersection of roof and wall, } 6 \mathrm{ft} 0 \text { in. } \\
\text { from rear wall }\end{array}$ & 43949 & 1.1 \\
\hline 8 & $\begin{array}{l}\text { Intersection of roof and wall, } 7 \mathrm{ft} 0 \mathrm{in.} \\
\text { from rear wall }\end{array}$ & 43950 & 1.5 \\
\hline 9 & $\begin{array}{l}\text { Intersection of roof and wall, } 8 \mathrm{ft} 0 \mathrm{in} \text {. } \\
\text { from rear wall }\end{array}$ & 43951 & 1.5 \\
\hline 10 & $\begin{array}{l}\text { Intersection of roof and wall, } 9 \text { ft } 0 \text { in. } \\
\text { from rear wall }\end{array}$ & 43952 & 1.6 \\
\hline 11 & $\begin{array}{l}\text { Intersection of roof and wall, } 10 \mathrm{ft} 0 \mathrm{in} \text {. } \\
\text { from rear wall }\end{array}$ & 43953 & 2.0 \\
\hline 12 & Mid-height of door (interior) & 43955 & 7.6 \\
\hline 13 & Mid-height of door (exterior) & 43956 & 12.0 \\
\hline \multicolumn{4}{|c|}{ Open shot, Station $31.1 \mathrm{~b}-2(7800 \mathrm{ft})$} \\
\hline 1 & $\begin{array}{l}\text { Mid-height of end wall along center } \\
\text { line }\end{array}$ & 43899 & 0.18 \\
\hline 2 & $\begin{array}{l}\text { Intersection of roof and wall, } 1 \mathrm{ft} 0 \mathrm{in} \text {. } \\
\text { from rear wall }\end{array}$ & 43901 & 0.1 \\
\hline 3 & $\begin{array}{l}\text { Intersection of roof and wall, } 2 \mathrm{ft} 0 \text { in. } \\
\text { from rear wall }\end{array}$ & 43902 & 0.1 \\
\hline 4 & $\begin{array}{l}\text { Intersection of roof and wall, } 3 \mathrm{ft} 0 \mathrm{in} \text {. } \\
\text { from rear wall }\end{array}$ & 43903 & 0.18 \\
\hline 5 & $\begin{array}{l}\text { Intersection of roof and wall, } 4 \mathrm{ft} 0 \mathrm{in} \text {. } \\
\text { from rear wall }\end{array}$ & 43904 & 0.23 \\
\hline 6 & $\begin{array}{l}\text { Intersection of roof and wall, } 5 \mathrm{ft} 0 \text { in. } \\
\text { from rear wall }\end{array}$ & 43905 & 0.27 \\
\hline 7 & $\begin{array}{l}\text { Intersection of roof and wall, } 6 \mathrm{ft} 0 \mathrm{in} \text {. } \\
\text { from rear wall }\end{array}$ & 43906 & 0.18 \\
\hline 8 & $\begin{array}{l}\text { Intersection of roof and wall, } 7 \mathrm{ft} 0 \mathrm{in} \text {. } \\
\text { from rear wall }\end{array}$ & 43907 & 0.15 \\
\hline 9 & $\begin{array}{l}\text { Intersection of roof and wall, } 8 \mathrm{it} 0 \mathrm{in} \text {. } \\
\text { from rear wall }\end{array}$ & 43908 & 0.15 \\
\hline 10 & $\begin{array}{l}\text { Intersection of roof and wall, } 9 \mathrm{ft} 0 \text { in. } \\
\text { from rear wall }\end{array}$ & 43909 & 0.20 \\
\hline 11 & $\begin{array}{l}\text { Intersection of roof and wall, } 10 \mathrm{ft} 0 \mathrm{in} \text {. } \\
\text { from rear wall }\end{array}$ & 43910 & 0.27 \\
\hline 12 & Mid-height of door (interior) & 43941 & 0.27 \\
\hline 13 & Mid-height of door (exterior) & 43942 & 0.27 \\
\hline
\end{tabular}

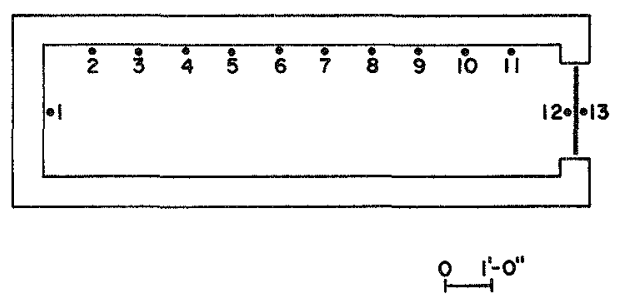

Fig. 2.11-Film dosimeter locations in basement reinforced-concrete room shelter in two-story frame houses; Stations $31.1 \mathrm{~b}-1$ and $\mathrm{b}-2$. 


\begin{tabular}{|c|c|c|c|}
\hline Pt. & Location & Dosimeter No. & Rea \\
\hline & \multicolumn{3}{|c|}{ Open shot, Station 31.1 a- $1(4700 \mathrm{ft})$} \\
\hline 1 & $\begin{array}{l}\text { Intersection of roof and wall, } 1 \text { ft } 6 \mathrm{in} \text {. } \\
\text { from center line of wall }\end{array}$ & 43997 & 1 \\
\hline 2 & $\begin{array}{l}\text { Intersection of roof and wall, } 6 \mathrm{~m} \text {. } \\
\text { from center line of wall }\end{array}$ & 43998 & 1 \\
\hline 3 & $\begin{array}{l}\text { Intersection of roof and wall, } 6 \mathrm{in} \text {. } \\
\text { from center line of wall }\end{array}$ & 43999 & 12 \\
\hline 4 & $\begin{array}{l}\text { Intersection of roof and wall, } 1 \mathrm{ft} 6 \mathrm{in} \text {. } \\
\text { from center line of wall }\end{array}$ & 44000 & 1 \\
\hline 5 & $\begin{array}{l}\text { Intersection of roof and wall, } 1 \mathrm{ft} 6 \mathrm{in} \text {. } \\
\text { from center line of wall }\end{array}$ & 44061 & 9 \\
\hline 6 & $\begin{array}{l}\text { Intersection of roof and wall, } 6 \mathrm{~m} \text {. } \\
\text { from center Ine of wall }\end{array}$ & 44062 & \\
\hline 7 & $\begin{array}{l}\text { Intersection of roof and wall, } 6 \mathrm{in} \text {. } \\
\text { from center line of wall }\end{array}$ & 44063 & \\
\hline 8 & $\begin{array}{l}\text { Intersection of roof and wail, } 1 \mathrm{ft} s \mathrm{in} \text {. } \\
\text { from center line of wall }\end{array}$ & 44064 & \\
\hline 9 & $\begin{array}{l}\text { Intersection of roof and wall, } 1 \mathrm{ft} 6 \mathrm{in} \text {. } \\
\text { from center line of wall }\end{array}$ & 44065 & 40 \\
\hline 10 & $\begin{array}{l}\text { Intersection of roof and wall, } 6 \mathrm{~m} \text {. } \\
\text { from center line of wall }\end{array}$ & 44066 & 40 \\
\hline 11 & $\begin{array}{l}\text { Intersection of roof and wall, } 6 \mathrm{~m} \text {. } \\
\text { from center line of wall }\end{array}$ & 44067 & 45 \\
\hline 12 & $\begin{array}{l}\text { Intersection of roof and wall, i ft } 6 \mathrm{in} \text {. } \\
\text { from center line of wall }\end{array}$ & 44068 & $\mathrm{Du}$ \\
\hline 13 & Mid-point of underside of roof & 44069 & $\pi 0$ \\
\hline 14 & Mid-pount of floor along wall & 44070 & 13 \\
\hline
\end{tabular}

Open shot, Station $31.12-2(10,500 \mathrm{ft})$

2

3

4

6 of roof and wall, $1 \mathrm{ft} 6$ in. from center line of wail

Intersection of roof and wall, $6 \mathrm{~m}$. from center line of wall

Intersection of roof and wall, $6 \mathrm{in}$. from center line of wall

Intersection of roof and wall, $1 \mathrm{ft} 6 \mathrm{~m}$. from center line of wall

Intersection of roof and wall, 1 it $6 \mathrm{in}$. from center line of wall

Intersection of roof and wall, $6 \mathrm{~m}$. from center line of wall

Intersection of roof and wall, $6 \mathrm{in}$. from center line of wall

Intersection of roof and wall, $1 \mathrm{ft} 6 \mathrm{ln}$. from center line of wall

Intersection of roof and wall, 1 ft $6 \mathrm{ln}$. from center line of wall

Intersection of roof and wall, $6 \mathrm{~m}$. from center line of wall

Intersection of roof and wall, $6 \mathrm{~m}$. from center line of wall

Intersection of roof and wall, $1 \mathrm{ft} 6$ in. from center line of wall

Mid-point of underside of roof Mid-point of floor along wall
12

25

50

40

0.1

0.1

0.15

0.1

0.15

0.15

0.1

0.15

0.1

0.15

0.1

0.18

0.18

0.15

8.3

6.3

3.3

3.3

5.6

6.2

20.0 


\begin{tabular}{|c|c|c|c|}
\hline Pt. & Location & Dosimeter No. & Reading, $\mathbf{r}$ \\
\hline \multicolumn{4}{|c|}{ Open shot, Station $31.1 \mathrm{~b}-1$ (5500 ft) (Continued) } \\
\hline 8 & $\begin{array}{l}\text { Intersection of roof and wall, } 1 \mathrm{ft} 6 \mathrm{in} \text {. } \\
\text { from center line of wall }\end{array}$ & 43969 & 14.0 \\
\hline 9 & $\begin{array}{l}\text { Intersection of roof and wall, } 1 \mathrm{ft} 6 \mathrm{in} \text {. } \\
\text { from center line of wall }\end{array}$ & 43970 & 18.0 \\
\hline 10 & $\begin{array}{l}\text { Intersection of roof and wall, } 6 \text { in. } \\
\text { from center line of wall }\end{array}$ & 43971 & 18.0 \\
\hline 11 & $\begin{array}{l}\text { Intersection of roof and wall, } 6 \mathrm{in} \text {. } \\
\text { from center line of wall }\end{array}$ & 43972 & 25.0 \\
\hline 12 & $\begin{array}{l}\text { Intersection of roof and wall, } 1 \mathrm{ft} 6 \mathrm{in} \text {. } \\
\text { from center line of wall }\end{array}$ & 43973 & 25.0 \\
\hline 13 & Mid-point of underside of roof & 43974 & 9.8 \\
\hline 14 & Mid-point of floor along wall & 43975 & 4.4 \\
\hline \multicolumn{4}{|c|}{ Open shot, Station $31.1 \mathrm{~b}-2$ (7800 ft) } \\
\hline 1 & $\begin{array}{l}\text { Intersection of roof and wall, } 1 \text { ft } 6 \text { in. } \\
\text { from center line of wall }\end{array}$ & 43885 & 0.8 \\
\hline 2 & $\begin{array}{l}\text { Intersection of roof and wall, } 6 \mathrm{in} \text {. } \\
\text { from center line of wall }\end{array}$ & 43886 & 0.6 \\
\hline 3 & $\begin{array}{l}\text { Intersection of roof and wall, } 6 \text { in. } \\
\text { from center line of wall }\end{array}$ & 43887 & 0.6 \\
\hline 4 & $\begin{array}{l}\text { Intersection of roof and wall, } 1 \mathrm{ft} 6 \mathrm{in} \text {. } \\
\text { from center line of wall }\end{array}$ & 43888 & 0.7 \\
\hline 5 & $\begin{array}{l}\text { Intersection of roof and wall, } 1 \text { ft } 6 \text { in. } \\
\text { from center line of wall }\end{array}$ & 43889 & 0.24 \\
\hline 6 & $\begin{array}{l}\text { Intersection of roof and wall, } 6 \text { in. } \\
\text { from center line of wall }\end{array}$ & 43890 & 1.2 \\
\hline 7 & $\begin{array}{l}\text { Intersection of roof and wall, } 6 \text { in. } \\
\text { from center line of wall }\end{array}$ & 43891 & 1.3 \\
\hline 8 & $\begin{array}{l}\text { Intersection of roof and wall, } 1 \mathrm{ft} 6 \mathrm{in} \text {. } \\
\text { from center line of wall }\end{array}$ & 43892 & 1.6 \\
\hline 9 & $\begin{array}{l}\text { Intersection of roof and wall, } 1 \mathrm{ft} 6 \mathrm{in} \text {. } \\
\text { from center line of wall }\end{array}$ & 43893 & 1.6 \\
\hline 10 & $\begin{array}{l}\text { Intersection of roof and wall, } 6 \mathrm{in} \text {. } \\
\text { from center line of wall }\end{array}$ & 43894 & 2.0 \\
\hline 11 & $\begin{array}{l}\text { Intersection of roof and wall, } 6 \text { in. } \\
\text { from center line of wall }\end{array}$ & 43895 & 2.2 \\
\hline 12 & $\begin{array}{l}\text { Intersection of roof and wall, } 1 \mathrm{ft} 6 \mathrm{in} \text {. } \\
\text { from center line of wall }\end{array}$ & 43896 & 2.5 \\
\hline 13 & Mid-point of underside of roof & 43897 & 1.6 \\
\hline 14 & Mid-point of floor along wall & 43898 & 0.2 \\
\hline
\end{tabular}

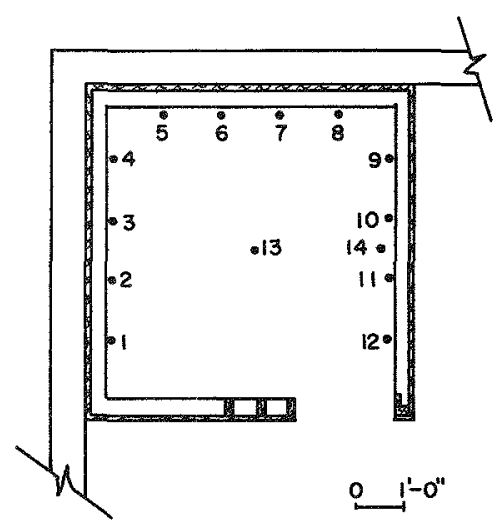

Fig. 2.12-Film dosimeter locations in basement corner-room shelters in twostory houses; Stations $31.1 \mathrm{a}-1, \mathrm{a}-2$, $\mathrm{b}-1$, and $\mathrm{b}-2$. 
Table 2.12-BASEMENT LEAN-TO SHELTER (FILM DOSIMETERS)

\begin{tabular}{|c|c|c|c|}
\hline Pt. & Location & Dosimeter No. & Reading, $\mathbf{r}$ \\
\hline \multicolumn{4}{|c|}{ Open shot, Station 31.1 a-1 (4700 ft) } \\
\hline 1 & Mid-helght of wall & 43992 & 6.5 \\
\hline 2 & $\begin{array}{l}\text { Underside of lean-to, } 1 \mathrm{ft} 6 \mathrm{~m} \text {. } \\
\text { from center line, mid-beight of } \\
\text { wall }\end{array}$ & 43993 & 6.7 \\
\hline 3 & $\begin{array}{l}\text { Underside of lean-to, } 6 \mathrm{ln} \text {. from center } \\
\text { line, mid-height of wall }\end{array}$ & 43994 & 6.7 \\
\hline 4 & $\begin{array}{l}\text { Underside of lean-to, } 6 \mathrm{in} \text {. from } \\
\text { center line, mid-height of wall }\end{array}$ & 43995 & 6.7 \\
\hline 5 & $\begin{array}{l}\text { Underside of lean-to, } 1 \mathrm{ft} 6 \mathrm{in} \text {. from } \\
\text { center line, mid-height of wall }\end{array}$ & 43996 & 6.7 \\
\hline \multicolumn{4}{|c|}{ Open shot, Station $31.1 \mathrm{a}-2(10,500 \mathrm{ft})$} \\
\hline 1 & Mid-height of wall & 44071 & $<0.1$ \\
\hline 2 & $\begin{array}{l}\text { Underside of lean-to, } 1 \mathrm{ft} 6 \mathrm{in} \text {. from } \\
\text { center line, mid-height of wall }\end{array}$ & 44072 & $<0.1$ \\
\hline 3 & $\begin{array}{l}\text { Underside of lean-to, } 6 \mathrm{in} \text {. from } \\
\text { center line, mid-height of wall }\end{array}$ & 44073 & $<0.1$ \\
\hline 4 & $\begin{array}{l}\text { Underside of lean-to, } 6 \mathrm{kn} \text {, from } \\
\text { center line, mid-height of wall }\end{array}$ & 44074 & $<0.1$ \\
\hline 5 & $\begin{array}{l}\text { Underside of lean-to, } 1 \mathrm{ft} 6 \mathrm{~m} \text {. from } \\
\text { center line, mid-height of wall }\end{array}$ & 44075 & $<0.1$ \\
\hline \multicolumn{4}{|c|}{ Open shot, Station $31.1 \mathrm{~b}-1(5500 \mathrm{ft})$} \\
\hline 1 & Mid-helght of wall & 43957 & 2.2 \\
\hline 2 & $\begin{array}{l}\text { Underside of lean-to, } 1 \mathrm{ft} 6 \mathrm{in} \text {. from } \\
\text { center line, mid-height of wall }\end{array}$ & 43958 & 3.2 \\
\hline 3 & $\begin{array}{l}\text { Underside of lean-to, } 6 \mathrm{in} \text {. from } \\
\text { center line, mid-height of wall }\end{array}$ & 43959 & 2.4 \\
\hline 4 & $\begin{array}{l}\text { Underside of lean-to, } 6 \text { in. from } \\
\text { center line, mid-height of wall }\end{array}$ & 43960 & 2.4 \\
\hline 5 & $\begin{array}{l}\text { Underside of lean-to, } 1 \mathrm{ft} 6 \mathrm{in} \text {. from } \\
\text { center line, mid-height of wall }\end{array}$ & 43961 & 2.2 \\
\hline \multicolumn{4}{|c|}{ Open shot, Station $31.1 \mathrm{~b}-2(7800 \mathrm{ft})$} \\
\hline 1 & Mid-height of wall & 43010 & 0.18 \\
\hline 2 & $\begin{array}{l}\text { Underside of lean-to, } 1 \mathrm{ft} 6 \mathrm{in} \text {. from } \\
\text { center line, mid-height of wall }\end{array}$ & 43881 & 0.22 \\
\hline 3 & $\begin{array}{l}\text { Underside of lean-to, } 6 \mathrm{kn} \text {. from } \\
\text { center line, mid-height of wall }\end{array}$ & 43882 & 0.22 \\
\hline 4 & $\begin{array}{l}\text { Underside of lean-to, } 6 \mathrm{in.} \text { from } \\
\text { center line, mid-height of wall }\end{array}$ & 43883 & 0.22 \\
\hline 5 & $\begin{array}{l}\text { Underside of lean-to, } 1 \mathrm{ft} 6 \mathrm{~m} \text {. from } \\
\text { center line, mid-height of wall }\end{array}$ & 43884 & 2.5 \\
\hline
\end{tabular}

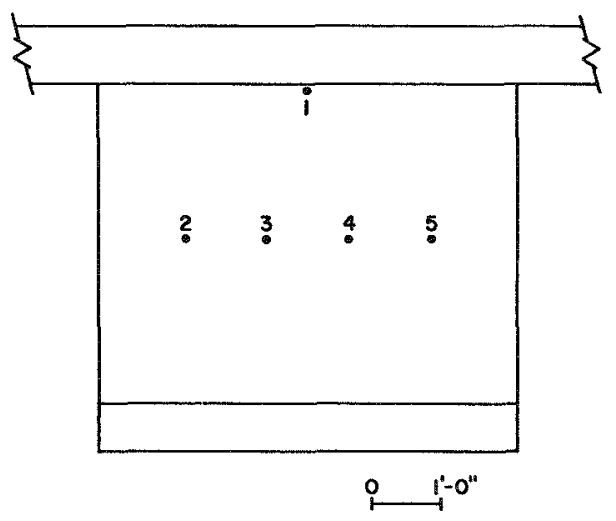

Fig. 2.13-Film dosimeter locations in basement lean-to shelters in two-story houses; Stations $31.1 \mathrm{a}-1, \mathrm{a}-2, \mathrm{~b}-1$, and $\mathrm{b}-2$. 


\section{CHAPTER 3}

\section{THERMAL CONVECTION}

\subsection{PREDICTED TEMPERATURES}

On two of the shots of Ope ration Upshot-Knothole, temperature measurements were made in an underground shelter. ${ }^{1}$ On an early shot only the measurement $14 \mathrm{ft}$ from the entrance was successful, and this was considerably higher than that predicted from the peak reflected pressure by the Rankine-Hugoniot relation. On a second shot measured temperatures and those calculated from peak reflected pressures agreed near the rear of the shelter. The most logical explanation for the higher temperatures near the entrance was that air preheated by thermal radiation near the ground surface was being forced into the shelter during the positive phase and evacuated during the negative phase. This explanation is satisfactory for the Upshot-Knothole shelter since it was a tube about $7 \mathrm{ft}$ in diameter and $48 \mathrm{ft}$ long, with the door symmetrically located in one end wall. The ratio of chamber cross-section area to door area was only 2.65. The hot air entering the door at one end had relatively little chance to mix with ambient air before being discharged through the door. Further evidence that there was little mixing is the fact that the temperature during the negative phase fell below ambient in each of four successful measurements.

The door of the 12- by $12-$ by $8-\mathrm{ft}$ Teapot shelter was not symmetrically located, and the ratio of chamber cross section to door area was over 8.0. Thus some mixing was to be expected, but the amount of mixing and, hence, whether the temperature would go below or return to ambient during the full pressure transient could not be anticipated. One would hope to extrapolate data from the Upshot-Knothole overpressure level to the overpressure level of the Teapot shelters by assuming no differences due to configuration. Because of the small size of the doorway with respect to shelter volume, it seemed reasonable that peak measured overpressures inside the shelter would be no greater than the expected incident overpressure. ${ }^{a}$ This was later verified in results of shock-tube tests. Fourteen feet from the entrance of the Upshot-Knothole shelter on the second shot, the measured temperature rise was less than twice that calculated for a peak measured overpressure. At the same point on the first shot, the measured temperature rise was about $3 \frac{3}{4}$ times that calculated for peak measured over pressure only $2 \frac{1}{2}$ times that of the second shot. If one assumes an extrapolated relation between measured and calculated temperatures, a measured temperature of between 3600 and $4500^{\circ} \mathrm{C}$ would be predicted at the shelter location. Using results of an earlier test, a temperature of $1000^{\circ} \mathrm{C}$ was predicted at $1050 \mathrm{ft} .{ }^{b}$

aHere and throughout this report the phrase "incident overpressure" refers to that overpressure incident upon a structure whether it is in the region of Mach or regular reflection.

${ }^{b}$ See WT-1161 for full development. 


\subsection{INSTRUMENTATION}

Since predicted transient peak temperatures for Teapot had rise times faster than existing thermocouples would measure, a velocity-of-sound gauge, with known dependence of the velocity of sound on temperature, was used. ${ }^{2}$ This gauge, still in an experimental stage and subject to failure, was used in pairs, one serving as backup for the other. This was fortunate since of eight gauges mounted in four positions one gauge in each position yielded a record which appeared satisfactory. It is probable that dust had an early effect on this gauge; even on those which gave apparently satisfactory records, the measurement was eventually affected by dust clogging the gauge orifice. None of the records was valid throughout the positive phase. There was an arrival time uncertainty which might have been as great as $40 \mathrm{msec}$, except for gauge $1 \mathrm{~B} 6$ where the uncertainty was less than $1 \mathrm{msec}$.

Electronic instrumentation was not available for temperature measurements in other than the underground personnel shelters in Program 34. However, passive detecting devices such as were used in Upshot-Knothole shelters ${ }^{3}$ were considered. They were not used because the predicted temperatures for Teapot were too low to register on the devices and because of the difficulty of interpreting them.

\subsection{RESULTS}

Records obtained on the open shot are reproduced in Figs. 3.1 and 3.2. Errors involved in reducing the records are no greater than \pm 7 per cent of the temperature in degrees Kelvin. It is uncertain whether the "hash" [for example, gauge $2 \mathrm{A2}$ (Fig. 3.2) between 240 and 310 $\mathrm{msec}$ ] is a high-frequency temperature transient or a spurious reading caused by turbulence or dust. Such high-frequency transients would not have been noted before because thermocouples used on earlier tests are not capable of responding to small transient pulses in air. These transients, if they are real, are of such short duration that their contribution to burning of occupants is offset by equal downward transients, and the average is probably the only significant temperature. Peak temperatures in the shelters are shown in Table 3.1.

Gauge 1B6 (Fig. 3.1) has an early peak $\left(250^{\circ} \mathrm{C}\right)$ at $230 \mathrm{msec}$, nearly $40 \mathrm{msec}$ after arrival of the shock wave.

\section{Underground Personnel Shelter (Biomedical): Open Shot (Station $34.3 \mathrm{~b}-2$ ).}

These are the two most valid records obtained (1B6, 2A2), Figs. 3.1 and 3.2. Arrival of the temperature pulse agrees with the arrival of the pressure pulse in the slow-fill room. In the fast-fill room, however, arrival of the pressure pulse precedes temperature pulse arrival by about $20 \mathrm{msec}$. If one concedes that the majority of the temperature increase is due to an influx of heated air from the outside, then the delay might be expected in the fast-fill room because of the longer passage the heated air has to traverse before arriving in the room. Passage into the slow-fill side is short, and outside air enters rapidly behind the shock front.

Table 3.1 - PEAK TEMPERATURES, OPEN SHOT

\begin{tabular}{lccccc}
\hline Station & Gauge & $\begin{array}{c}\text { Peak, } \\
{ }^{\circ} \mathrm{C}\end{array}$ & $\begin{array}{c}\text { Calculated } \\
\text { temp., }{ }^{\circ} \mathrm{C}\end{array}$ & $\begin{array}{c}\text { Time of } \\
\text { peak }\end{array}$ & $\begin{array}{c}\text { Measured temp. vs } \\
\text { cal. temp. }\end{array}$ \\
\hline $\begin{array}{l}34.3 \mathrm{~b}-2 \\
\text { Fast-fill }\end{array}$ & $1 \mathrm{~B} 6$ & $\mathbf{2 1 5}-225$ & 270 & 290 & $0.8-0.83$ \\
(Early peak) & & $300-320$ & & 230 & $1.1-1.2$ \\
Slow-fill & 2A2 & $340-360$ & 95 & 280 & $3.6-3.8$ \\
\hline
\end{tabular}

\footnotetext{
${ }^{a}$ By Rankine-Hugoniot.
} 


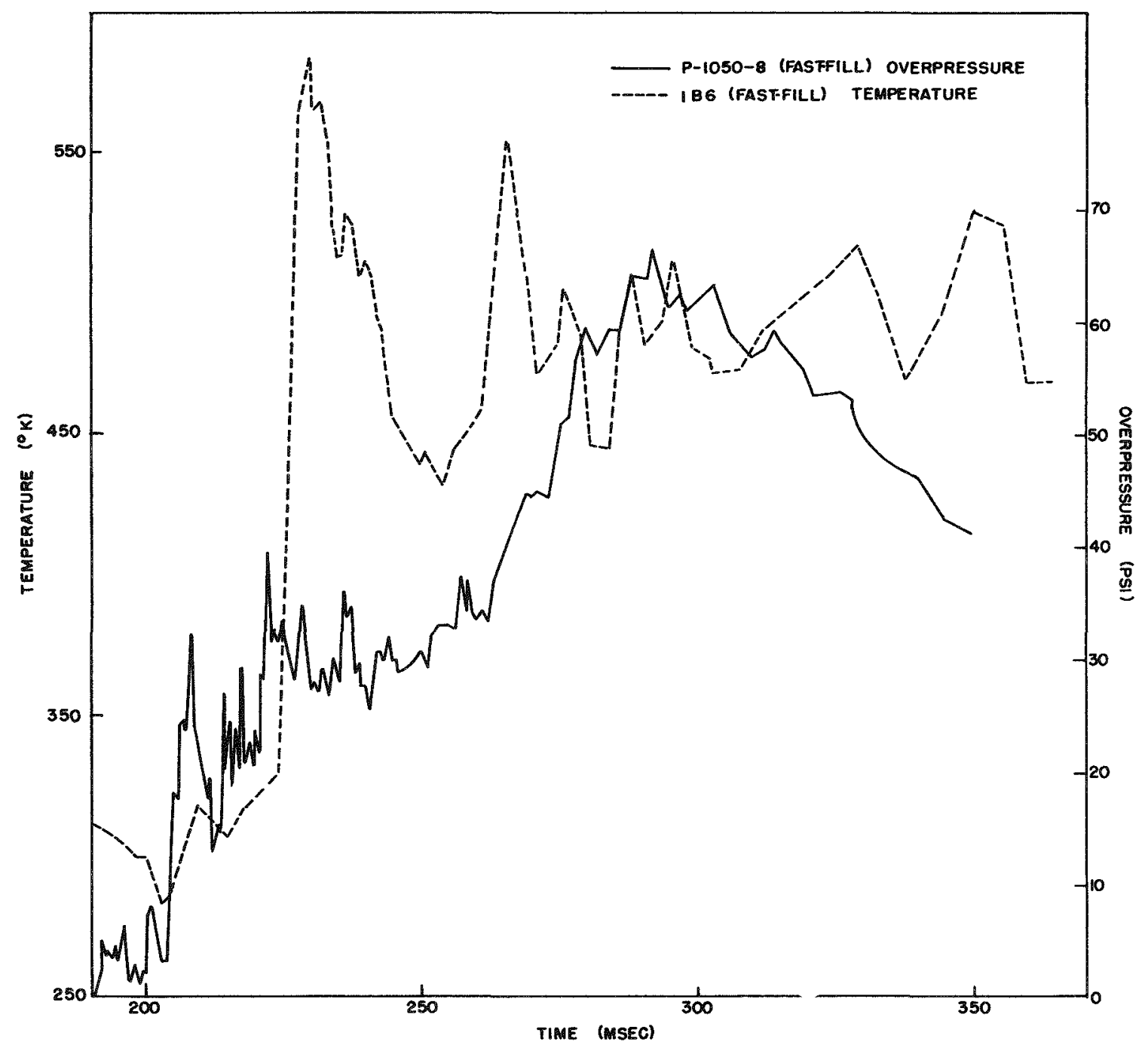

Fig. 3.1 - Temperature and overpressure in fast-fill room, underground personnel shelter, open shot Station 34.3 b-2. 


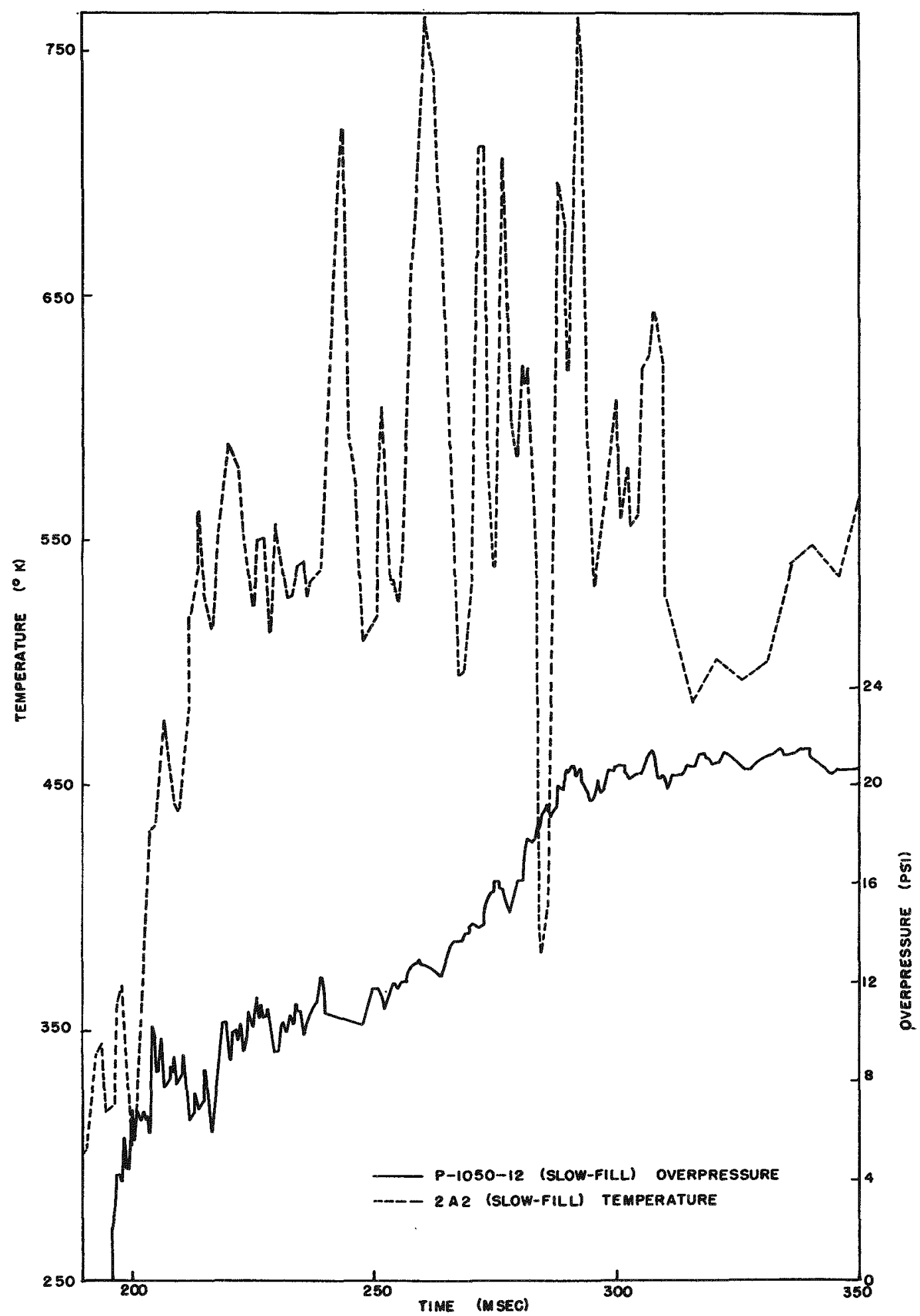

Fig. 3.2-Temperature and overpressure in slow-fill room, underground personnel shelter, open shot: Station 34.3 j-2. 


\section{REFERENCES}

1. E. W. Ruhl, AEC Shelter Instrumentation, Operation Upshot-Knothole Report, WT-790, August 1953.

2. G. W. Rollosson, Static and Dynamic Overpressure Measurements, Operation Teapot Report, ITR-1192 (to be superseded by WT-1192).

3. J. B. Byrnes, Effects of an Atomic Explosion on Underground and Basement Type Home Shelters, Operation Upshot-Knothole Report, WT-801, March-June 1953. 


\section{CHAPTER 4}

\section{BLAST EFFECTS}

Structures were located (Figs. 1.22 and 1.23) so as to receive a desired overpressure, estimates of which were based on IBM Problem M and the results of earlier tests. Below 8 psi measured overpressures agree with predictions. Above, they lie between the predictions of IBM Problem $M$ and the earlier experimental results.

\subsection{UNDERGROUND PERSONNEL SHELTER (STRUCTURAL)}

\subsubsection{Early Shot (Station 1)}

Three gauges were placed in the closed shelter on the earlier shot. One was placed in the vestibule at the foot of the stairs between the sliding concrete door and the metal pressuretight door to determine if there were any leakage in the outside door. This gauge rose to a peak of 4 psi at $317 \mathrm{msec}$, then settled at 1 psi until cable failure at $381 \mathrm{msec}$. Inside the main room, another gauge was placed behind the diffusion-board panel near the ventilation intake to check the efficiency of the antiblast closure valves. The gauge cable broke at $106 \mathrm{msec}$ after shock arrival outside, but to that time no overpressure was recorded. The third gauge was located near the escape hatch but not behind the diffusion-board panel. The cable to this gauge broke $73 \mathrm{msec}$ after shock arrival outside, and to that time no overpressure was recorded. The absence of overpressure at these two stations indicates that the antiblast closures operated satisfactorily.

\subsubsection{Open Shot (Station 34.3 a-2)}

Peak incident overpressure was nearly the anticipated 100 psi.

Three gauges were placed in the shelter: one in the large room, one in the exhaust room for the ventilating equipment, and one in the intake room. No overpressure had developed in the large room $96 \mathrm{msec}$ after shock arrival when the gauge failed or the cable broke. The gauge in the exhaust room failed at zero time. The gauge in the intake room registered a positive overpressure of less than 0.2 psi, indicating that the antiblast closures worked properly. However, since these antiblast closures are one-way devices, they permitted evacuation of air from the room and a negative pressure of 1.69 psi.

Based on free-soil accelerations on earlier tests, ${ }^{1}$ a maximum vertical acceleration of $25 \mathrm{~g}$ had been expected, but the measured vertical acceleration had a maximum positive (downward) acceleration of only $3.7 \mathrm{~g}$ (Fig. 4.1). This gives a maximum positive velocity of $2.2 \mathrm{ft} / \mathrm{sec}$ and a maximum downward displacement of nearly $1.7 \mathrm{in}$. occurring at $470 \mathrm{msec}$ (Fig. 4.1). Since all the displacement was downward, these accelerations should cause no harmful effect on occupants of the shelter. 

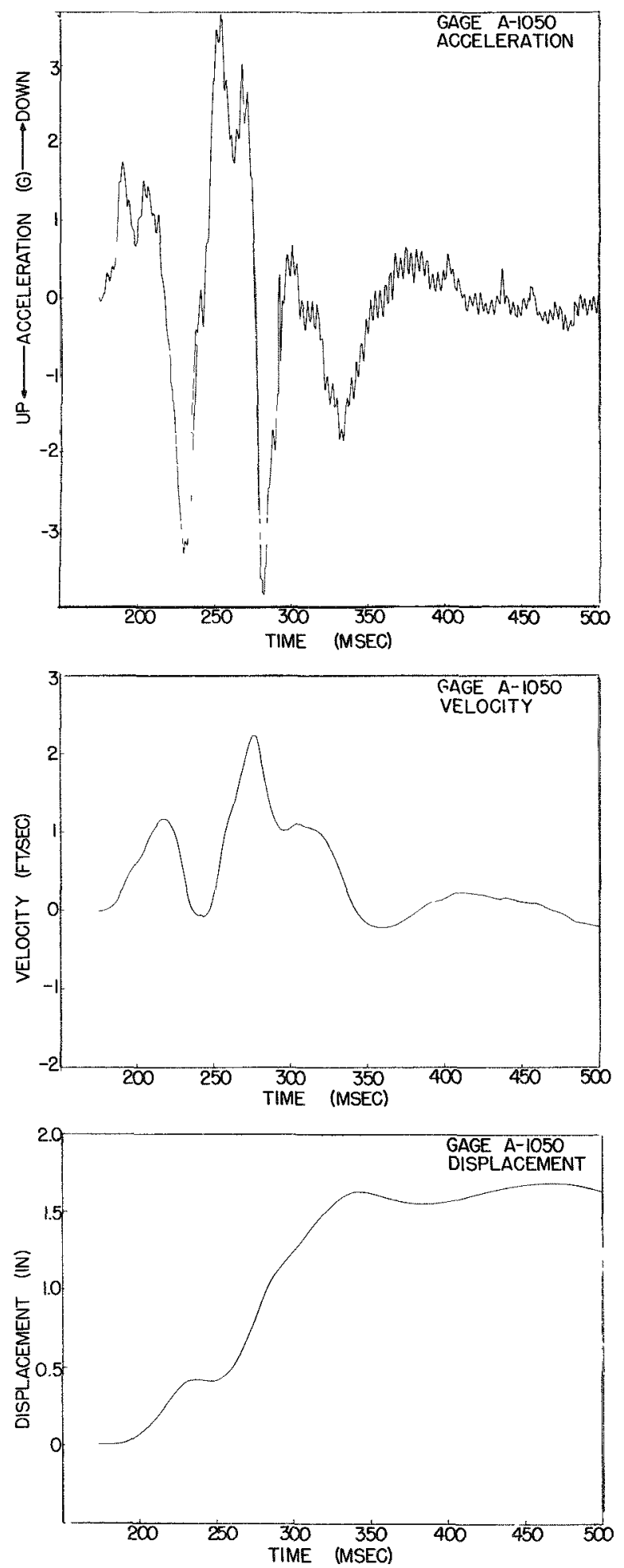

Fig. 4.1-Acceleration, velocity, and displacement records, underground personnel shelter, open shot. 


\subsection{UNDERGROUND PERSONNEL SHELTER (BIOMEDICAL)}

For Project 33.1 requirements, ${ }^{2}$ the entrance to the fast-fill room was left open, and the escape hatch in the slow-fill side was covered with a steel plate with a 19-in.-diameter hole in the center to meter air slowly into the shelter. For the open shot this air inlet was enlarged to 36 in. in diameter.

\subsubsection{Early Shot (Station 2)}

In the fast-fill side eight gauges were located as shown in Fig. 1.19 to give pressures at particular points for Project 33.1, and a q-tube was placed $6 \mathrm{ft}$ from the door to measure dynamic pressure. In the slow-fill side one pressure gauge was located near the center of each wall (Fig. 1.19).

Measured dynamic pressure rose rapidly in the fast-fill room to nearly 7 psi at shock arrival, becoming negative some $10 \mathrm{msec}$ later as the front was reflected off the back wall and the flow reversed. Flow became positive again during the approximately $15 \mathrm{msec}$ it took the room to fill while the front was being rereflected off the front wall, with the peak dynamic pressure rising to over $12 \mathrm{psi}$. Thereafter, flow remained positive until $430 \mathrm{msec}$, indicating that the room continued to fill to that time.

For gauges on the wall to the left of the entrance of the fast-fill side, passage of the initial front and its reflection off the back wall can be noted. Thereafter, reverberations between one wall and another and between the floor and ceiling are superimposed, and it is difficult to attribute any one signal to a particular reflection. The peak overpressures inside were only about 75 per cent of the incident peak overpressure.

In the slow-fill side the configuration is such that with the pressure entering over one corner there should be similarities between gauges 10 and 11 and between 9 and 12 (Fig. 1.19). The cable to gauge 12 broke at $65 \mathrm{msec}$, and gauge 10 was valid only to $76 \mathrm{msec}$; but to those times some similarities are apparent. Because the pressure wave enters the slow-fill side from above, one might expect the reverberations between the floor and the ceiling to be stronger than those between opposite walls. There is nothing in the records to substantiate this, however. Peak overpressures measured inside were only about one-eighth the peak incident overpressure.

\subsubsection{Open Shot (Station $34.3 \mathrm{~b}-2$ )}

Gauge locations were identical to those for the earlier shot (Fig. 1.19).

Measured overpressure inside both fast- and slow-fill rooms differed little from those of the early shot except for amplitude. The peak overpressure inside the fast-fill side was about 75 per cent of the incident peak, whereas that inside the slow-fill side increased to nearly 25 per cent of the incident due primarily to the increase in the diameter of the circular opening from 19 to $36 \mathrm{in.}$ On many of the records it is possible to identify similar characteristics of the blast wave as it was reflected back and forth inside the room. There were significant differences in the shapes of the dynamic pressure waves. The open shot record between 195 and 225 msec disagrees with the record from the earlier shot and is inconsistent with the overpressure records from near the q-gauge. For this reason $30 \mathrm{msec}$ of the open shot record is discounted.

Dynamic pressure as measured should be a function of the overpressure differential inside and outside the shelter. The overpressure differential indicates when the shelter is filling and emptying. When it is emptying the dynamic pressure should be negative. The dynamic pressure as recorded in this station is in poor agreement with the overpressure differential.

\subsection{BASEMENT EXIT SHELTERS}

\subsubsection{Early Shot (Stations 3, 4, 5)}

Station 3 was closed, Station 4 was partially closed, and Station 5 was open. These were instrumented with two pressure gauges for Project 33.1: one inside $2 \mathrm{ft}$ from the end wall on the wall nearest GZ and one inside $2 \mathrm{ft}$ from the entrance on the same wall (Fig. 1.9). 
The restricted entrance of the closed shelter after door failure reduced the overpressure inside to about 75 per cent of the incident.

For the open and partially closed shelters, differences resulting from the two opening configurations appear to be small. In both shelters peak overpressures measured were more than twice the peak incident overpressure.

\subsubsection{Open Shot (Stations $34.1 \mathrm{c}-1, \mathrm{c}-2, \mathrm{~d}-1, \mathrm{~d}-2$ )}

Pressure in the closed shelter located at $1270 \mathrm{ft}(\mathrm{c}-1)$ rose rapidly enough to indicate that the doors failed almost instantly. Some reverberation can be seen on the pressure record; little reverberation, however, appeared on the open shelter $(c-2)$ record, perhaps because of the excessive damage done to the open end. Peak overpressure measured inside both shelters was nearly twice the peak incident overpressure.

Peak overpressures inside the closed shelter were only about two-thirds the estimated peak incident overpressure. That this is so much less than for the other identical shelters indicates that the improved latch kept the door intact for a longer time. No measurement was made inside the open shelter (d-2).

\subsection{UTILITY TYPE SHELTERS, OPEN SHOT}

These shelters were subjected to incident overpressures of nearly the design pressures. The pressure in two of the three shelters built up slowly. The first shelter rolled over, breaking the cable to the pressure gauge before any pressure was recorded.

Maximum overpressures inside the two surviving sets of aboveground utility shelters rose to peaks of 4.3 and 2.6 psi, respectively, and decayed slowly. Thus they were reduced to about 35 per cent of the incident.

\subsection{INDOOR FAMILY TYPE SHELTERS}

\subsubsection{Open Shot (Station 31.1 c-1)}

The rambler house at $4700 \mathrm{ft}$ was subjected to an incident overpressure of 5.1 psi (Fig. 4.2). The pressure inside the bathroom shelter (P-4700-1, Fig. 4.2) rose slowly to 1.3, or to less than one-third the peak incident overpressure, then decayed slowly. For incident overpressure records taken at 10,500 ft, where the last bathroom shelter was located, see Fig. 4.3.

\section{4,5.2 Open Shot (Stations $31.1 \mathrm{a}-1$ and $\mathrm{b}-1$ )}

The two-story brick house at $4700 \mathrm{ft}$ was subjected to an incident overpressure of 5.1 psi. The overpressure inside the basement lean-to shelter (P-4700-2, Fig. 4.2) rose slightly as the shock came in the nearest window, increasing to $4.6 \mathrm{psi}$ (only slightly below the incident) as the pressure built up within the basement.

At $5500 \mathrm{ft}$ the two-story house in which the basement corner-room shelter was located was subjected to an incident overpressure of about 4 psi. The record (p-5500, Fig. 4.3) reflects the general rise to $3.7 \mathrm{psi}$ within the basement. The shape of the pressure record inside was different from that outside. The fast rise of the incident wave was altered to a form with a slow rise that reached a maximum when the basement filled about $100 \mathrm{msec}$ after shock arrival.

\section{REFERENCES}

1. V. Salmon and S. R. Hornig, Earth Acceleration Vs Time and Distance, Operation TumblerSnapper Report, WT-517, December 1952.

2. C. S. White et al., Effects of Overpressures on Biological Systems, Operation Teapot Report, ITR-1179 (to be superseded by WT-1179). 

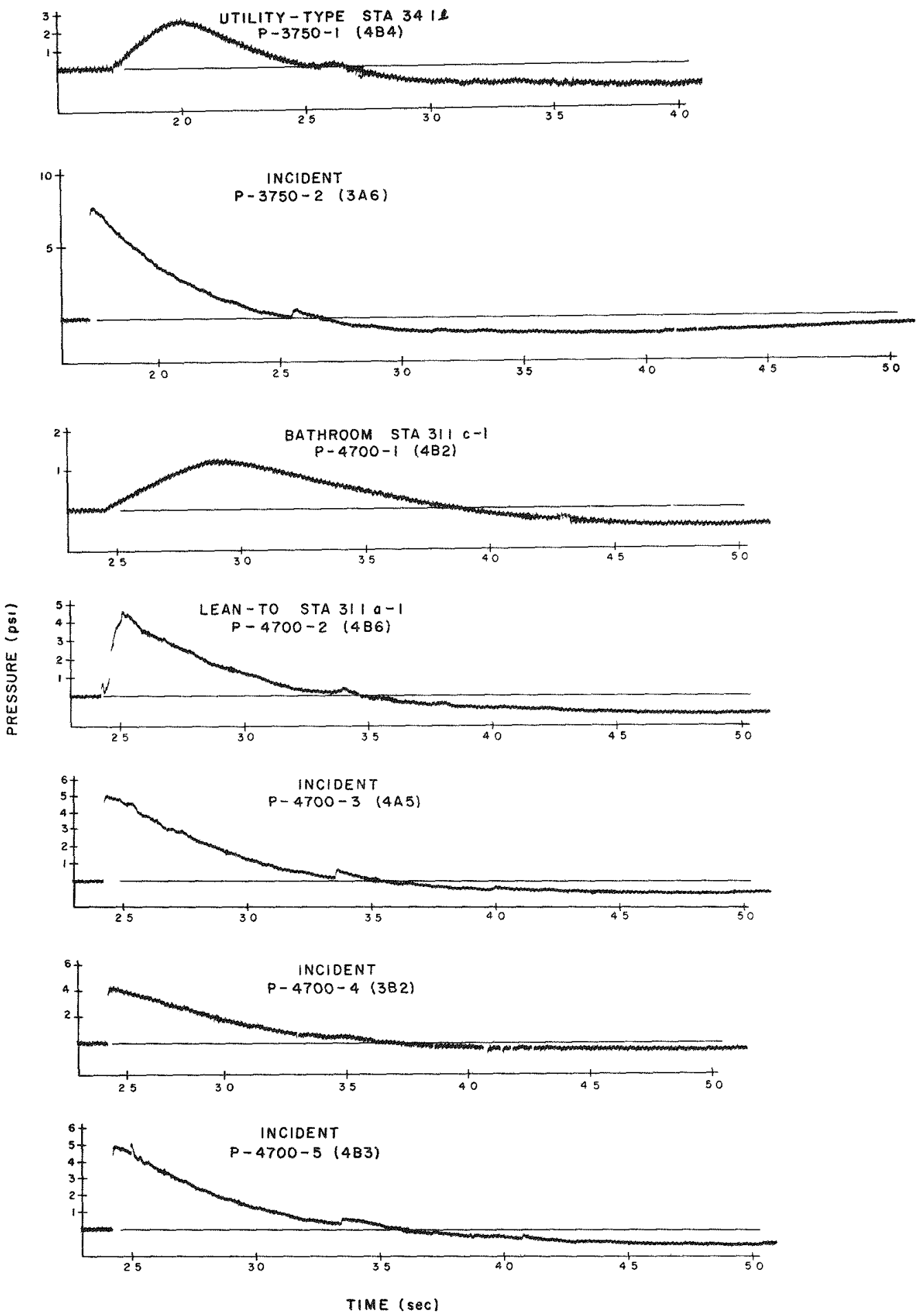

Fig. 4.2-Pressure-time records, open shot. 

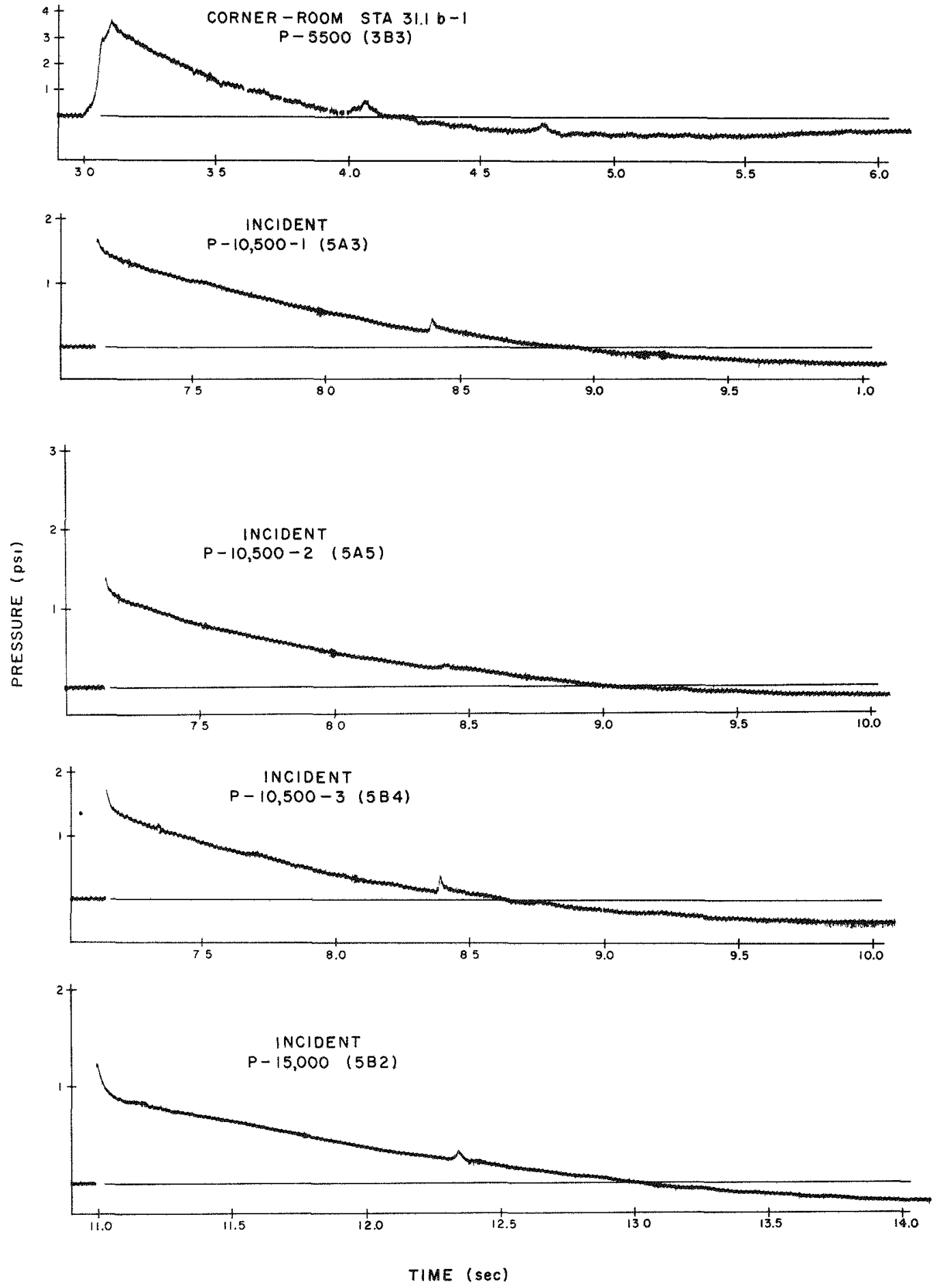

Fig. 4.3-Pressure-time records, open shot. 
CHAPTER 5

\section{STRUCTURAL DAMAGE}

\subsection{UNDERGROUND PERSONNEL SHELTERS (STRUCTURAL AND BIOMEDICAL)}

\subsubsection{Open Shot (Stations 34.3 a-2, b-2), $1050 \mathrm{Ft}$}

Neither shelter suffered structural damage, but dirt and missiles littered the stair wells (Fig. 5.1). The blast tore off the vent tees at the junction of the tee and the vertical pipe.

(a) Station $34.3 a-2$. The Army Chemical Corps ventilation equipment suffered no discernible damage. The failure of one of the rebound bolts from shearing of the thread indicates that these bolts were loaded to the limit of their capacity at the test pressure. An increase in bolt diameter, and therefore thread capacity, would supply a reserve strength to the rebound connection.

Two wheels of the sliding door were destroyed by missiles, and the rubber door bumper blew into the stair well. Destruction of the wheels can be prevented by widening the door slab to provide a protective lip for the wheels. Despite the loss of the wheels, the door could have been jacked open from the inside. The retaining wall around the concrete door was damaged (Figs. 5.1 and 5.2).

(b) Station $34.3 b-2$. Because of the larger opening (36 in. instead of 19 in.) in the slowfill side escape hatch, the peak unbalanced pressure between the rooms in the biomedical shelter was proportionately less than on the earlier shot, and the reinforced door frames in the partition wall sustained no plastic deformation from this unbalanced pressure.

\subsection{BASEMENT EXIT SHELTERS}

\subsubsection{Open Shot (Stations $34.1 \mathrm{c}-1, \mathrm{c}-2, \mathrm{~d}-1, \mathrm{~d}-2$ )}

Closed shelters at $1270 \mathrm{ft}$ sustained severe structural damage; all doors blew off in the positive phase, and rebound locks and retaining walls failed (Fig. 5.3) under a pressure of 45 psi. Interior walls were cracked and had outward deformations caused by an unbalance of interior over exterior pressure. This unbalance could be eliminated by a revised door design.

Closed shelters at $1470 \mathrm{ft}$ suffered little interior damage, but all doors and retaining walls failed, apparently during the negative phase (Fig. 5.4).

Damage to open shelters at 1270 and $1470 \mathrm{ft}$ reflected their respective distances from GZ. At $1270 \mathrm{ft}$ the roof and side walls failed-the former from upward distortion, the latter from outward distortion. Retaining and entranceway side walls failed (Fig. 5.5). At $1470 \mathrm{ft}$ retaining walls failed (Fig. 5.6), and interior walls cracked (Fig. 5.7) but not as severely as those at $1270 \mathrm{ft}$.

On each, some earth cover was blown away, and vent pipes were either blown away or bent. 


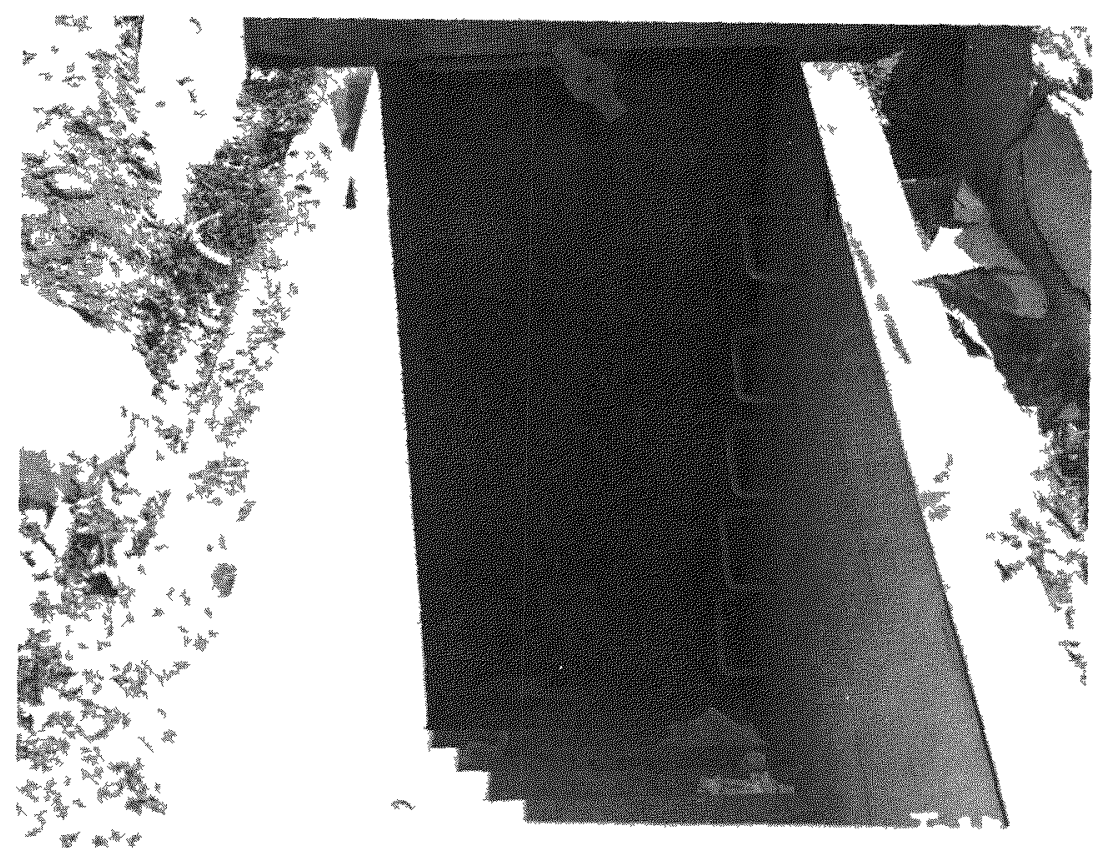

Fig. 5.1-Shelter entrance, open shot; Station $34.3 \mathrm{a}-2$.

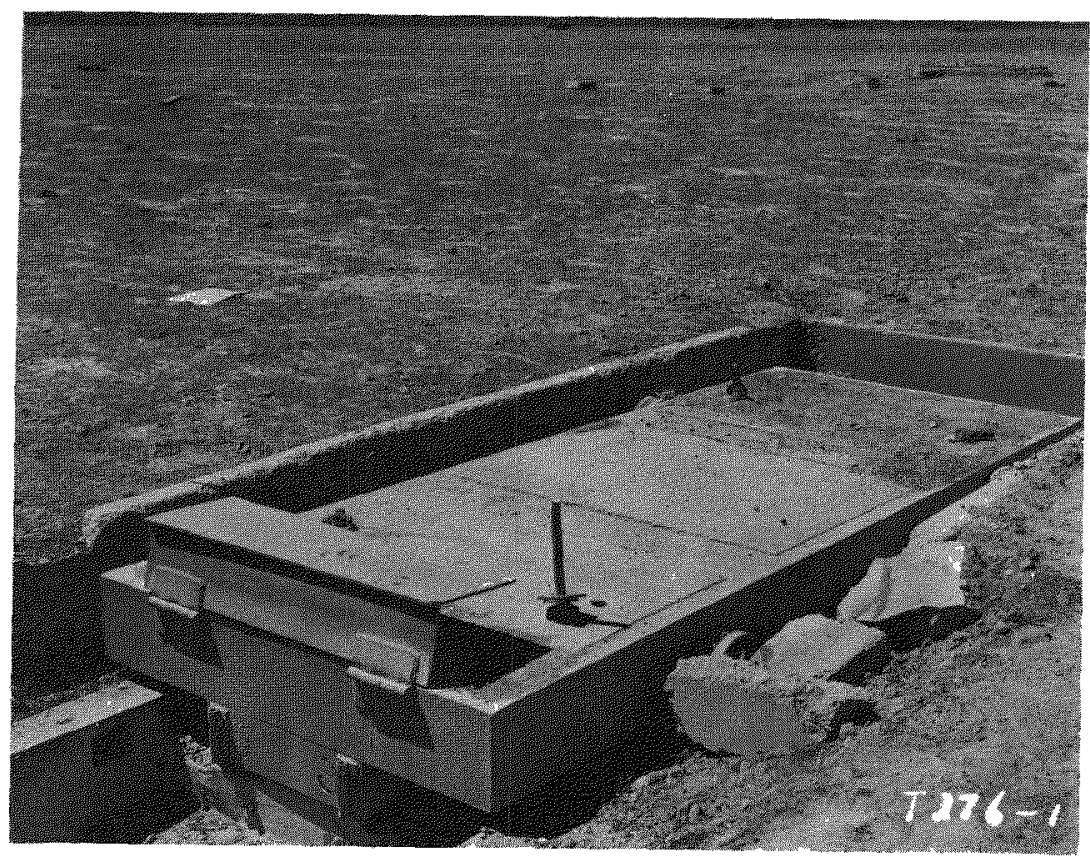

Fig. 5.2-Sliding door slab, open shot; Station 34.3 a-2. 


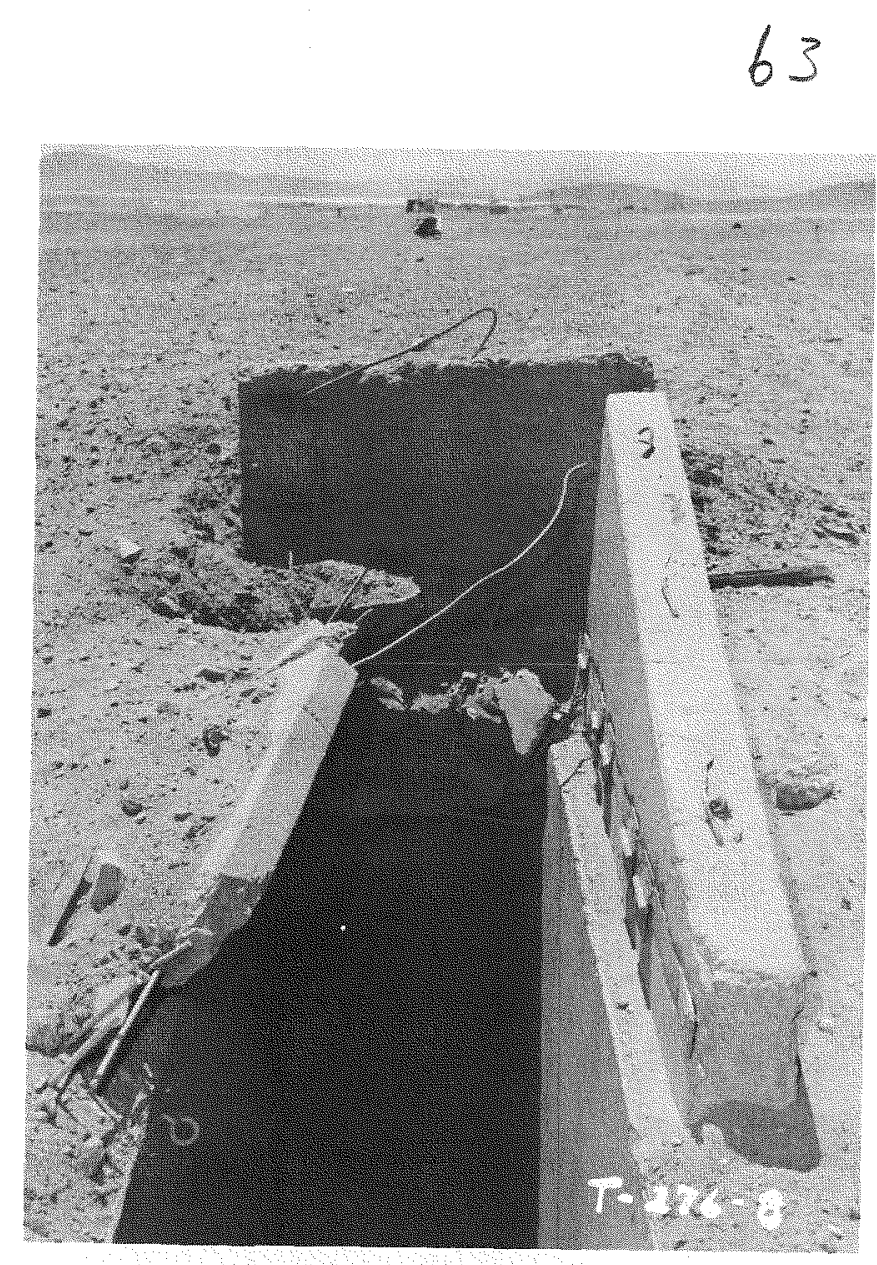

Fig. 5.3-Entrance to closed basement exit shelter, $1270 \mathrm{ft}$, open shot; Station $34.1 \mathrm{c}-1$.

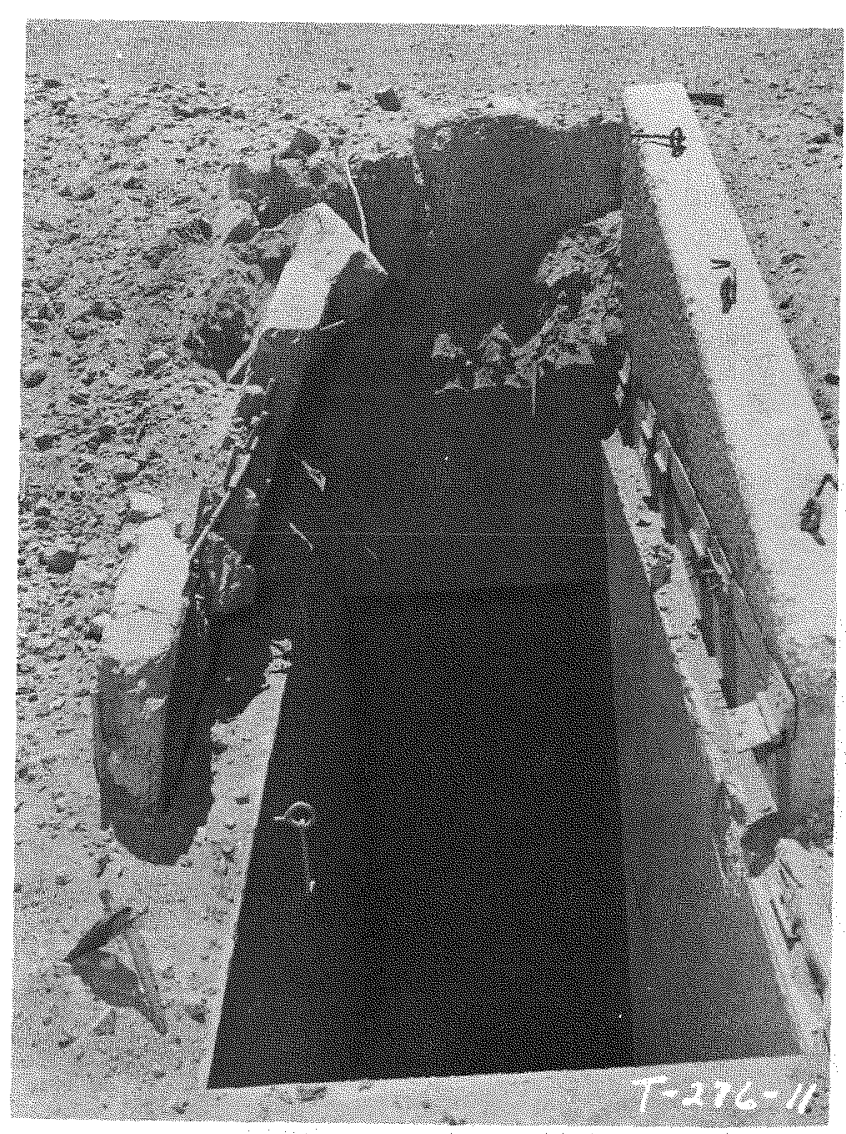

Fig. 5.4-Entrance to closed basement exit shelter, $1470 \mathrm{ft}$ open shot: Station $34.1 \mathrm{~d}-1$. 


\section{4}

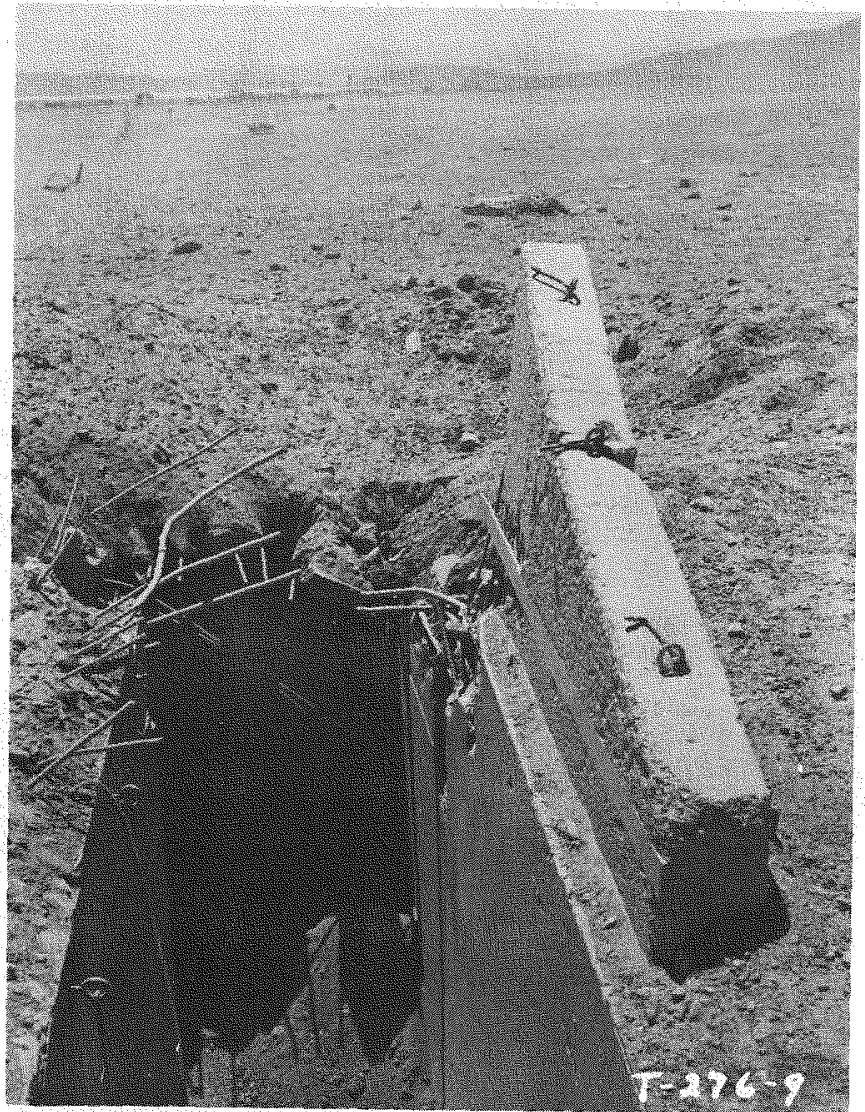

Fig. 5.5 - Entrance to open basement exit shelter, $1270 \mathrm{ft}$, open shot: Station $34.1 \mathrm{c}-2$.

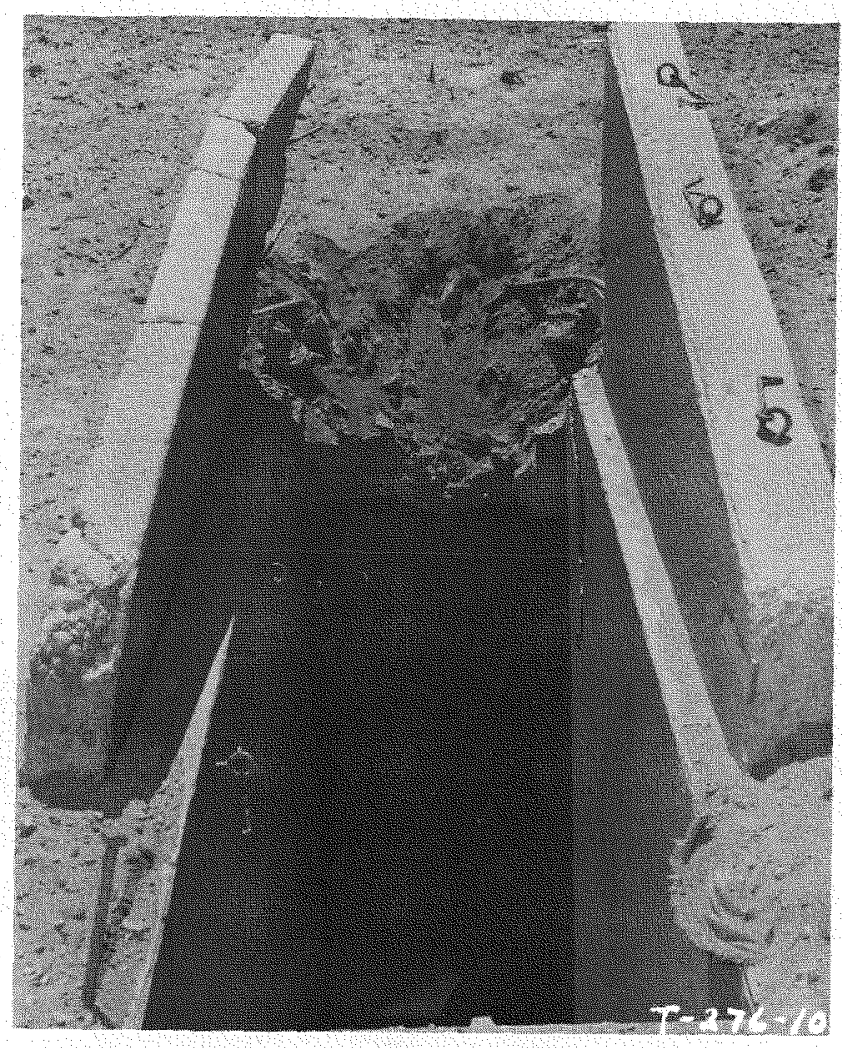

Fig. 5.6-Entrance to open basement exit shelter, $1470 \mathrm{ft}$ open shot: Station 34.1 d-2. 


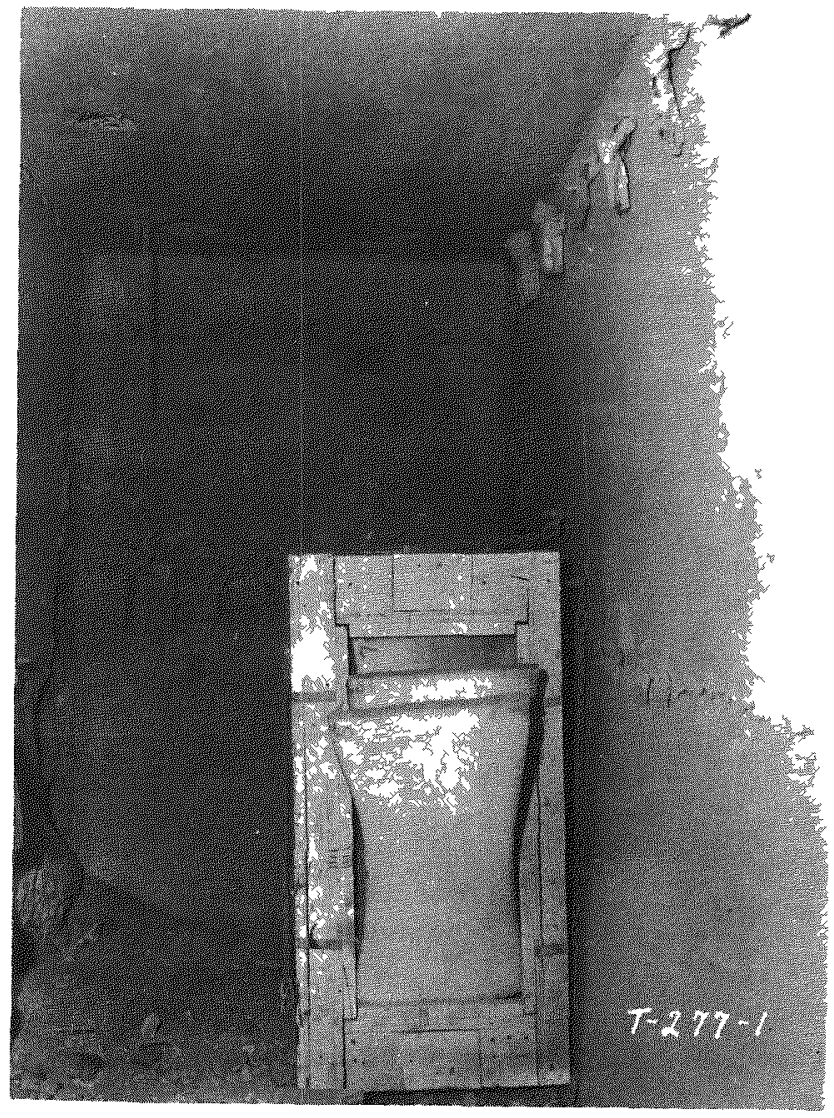

Fig. 5.7-Interior of open basement exit shelter, $1470 \mathrm{ft}$, open shot: Station $34.1 \mathrm{~d}-2$. 


\subsection{UTILITY TYPE SHELTERS}

\subsubsection{Open Shot (Stations 34.1 e, f, and g), $2250 \mathrm{Ft}$}

The masonry shelter disintegrated (Fig. 5.8); the poured-in-place reinforced-concrete shelter remained intact but was swept $50 \mathrm{ft}$ from its original position to lie on its side (Fig. 5.9); and the precast reinforced-concrete shelter failed (Fig. 5.10). On the latter, roof failure occurred in the slab and not in the high-strength bolts used to tie the roof to the walls. Door fastenings failed on the poured-in-place structure, and on the precast shelter the doors blew away.

\subsubsection{Open Shot (Stations $34.1 \mathrm{~h}, \mathrm{i}$, and j), $2750 \mathrm{Ft}$}

These three shelters remained in place under slightly more than 10 psi, the design pressure, and suffered no discernible damage. This indicates that the structures have the required strength and stability at the design pressure but have little reserve strength against an increase of this pressure.

Outer doors were intact, but there was some evidence that rebound latches yielded. Each interior door was blown off its hinges, and the latch was found lying against the opposite wall. Failure of the interior door connections would not have occurred had the doors been left open as was intended by the designers.

\subsubsection{Open Shot (Stations $34.1 \mathrm{k}, 1$, and $\mathrm{m}$ ), $3750 \mathrm{Ft}$}

The shelters suffered no structural damage. Inner doors, however, also failed at the hinges and latches at this distance. The bolts latching the outer door of Station $34.1 \mathrm{~m}$ were badly deformed, but on the whole the rebound latches were effective-more effective than the original design which featured latches on the inside of the door.

\subsection{INDOOR FAMILY TYPE SHELTERS}

Basement lean-to shelters in the brick and wood-frame houses on open shot (at 4700 , 5500,7800 , and $10,500 \mathrm{ft}$ ) suffered no damage. Despite the fact that the houses at the closer ranges were virtually destroyed, the first floor framing system did not fail, and there was no debris load in the basement.

Basement corner-room shelters in the same houses as the lean-to shelters were undamaged, as were the reinforced-concrete basement shelters in wood-frame houses at 5500 and $7800 \mathrm{ft}$.

Reinforced-concrete bathroom shelters in the one-story rambler houses at 4700 and $10,500 \mathrm{ft}$ suffered no damage (Fig. 5.11), although the house at $4700 \mathrm{ft}$ was totally destroyed and the shelter was subjected to a pressure of 5 psi. On each, the blast door was intact, but on the closest one the blast shutter latch failed. However, neither the glass nor the sash was broken. 


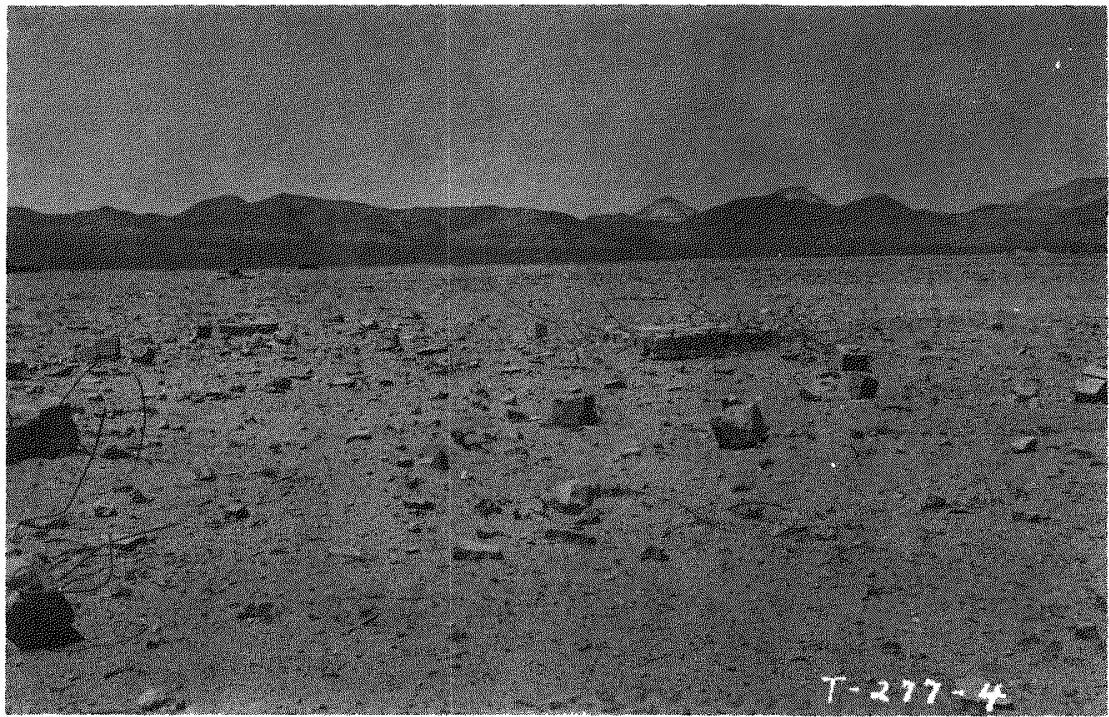

Fig. 5.8-Debris from masonry utility type shelter, $2250 \mathrm{ft}$, open shot: Station $34.1 \mathrm{e}$.

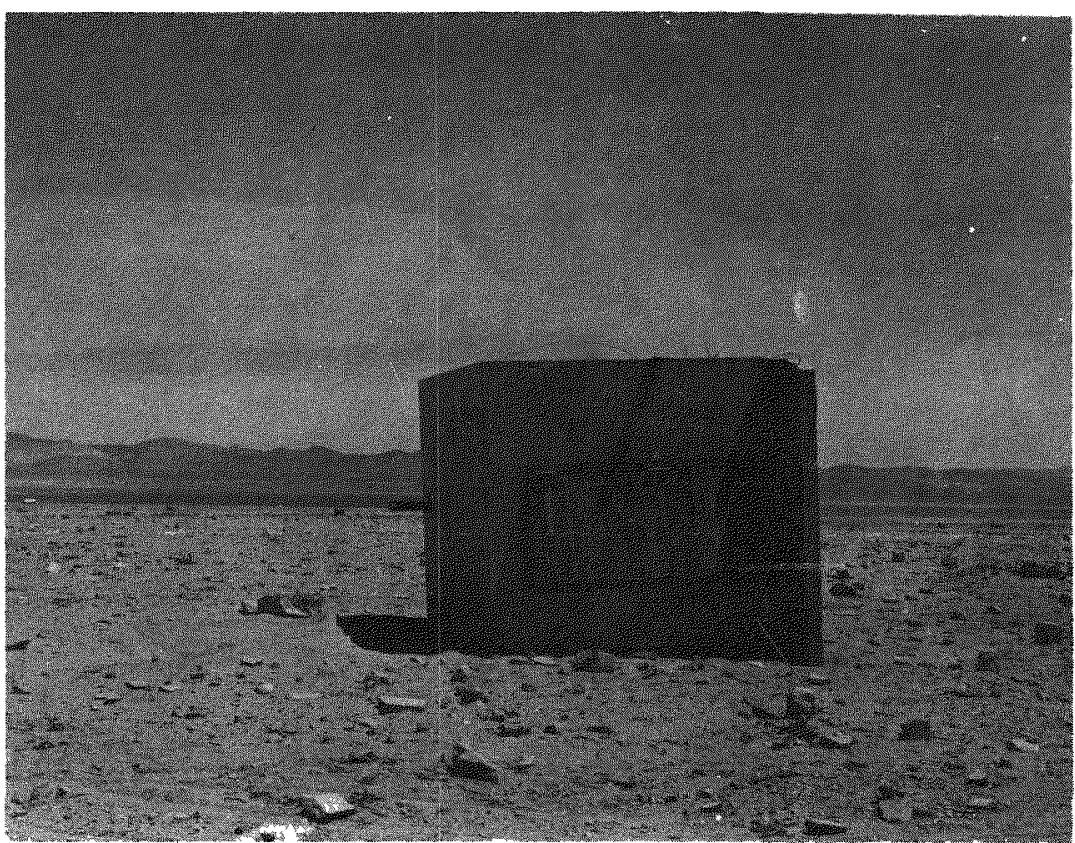

Fig. 5.9-Reinforced-concrete (poured-in-place) utility type shelter, 2250 ft, open shot; Station 34.1 f. 


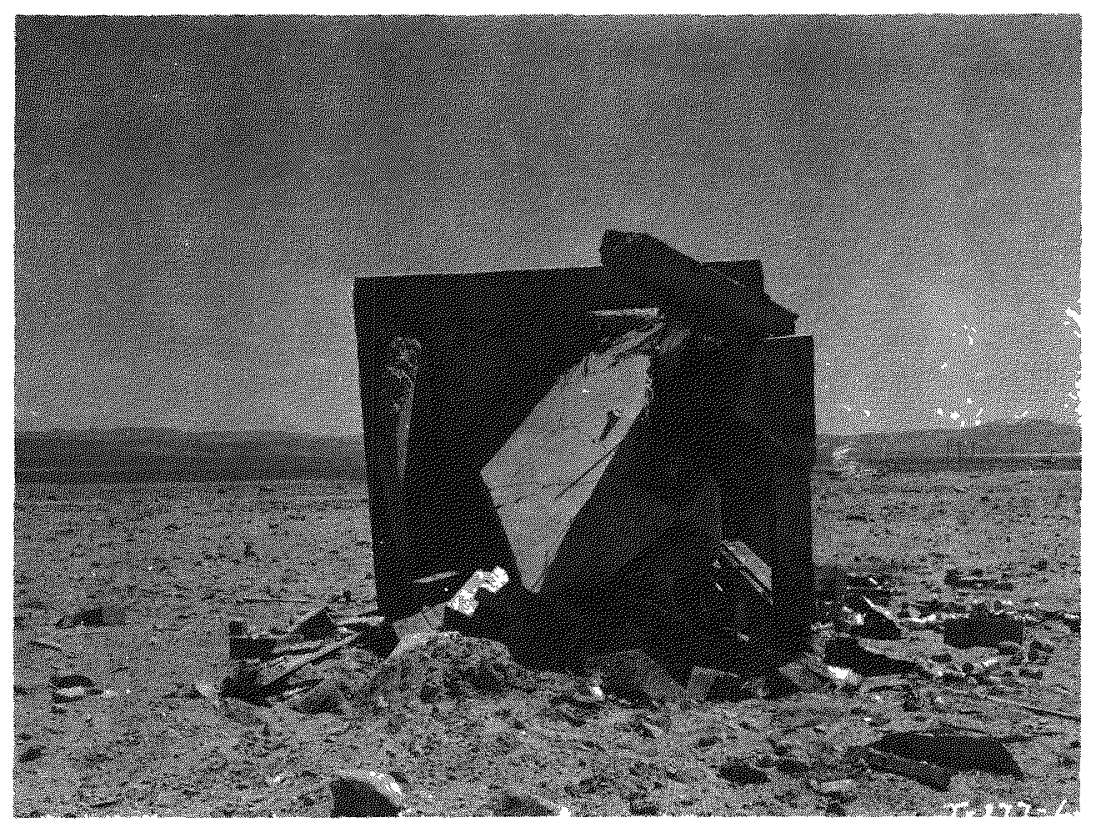

Fig. 5.10-Reinforced-concrete (precast) utility type shelter, $2250 \mathrm{ft}$, open shot; Station $34.1 \mathrm{~g}$.

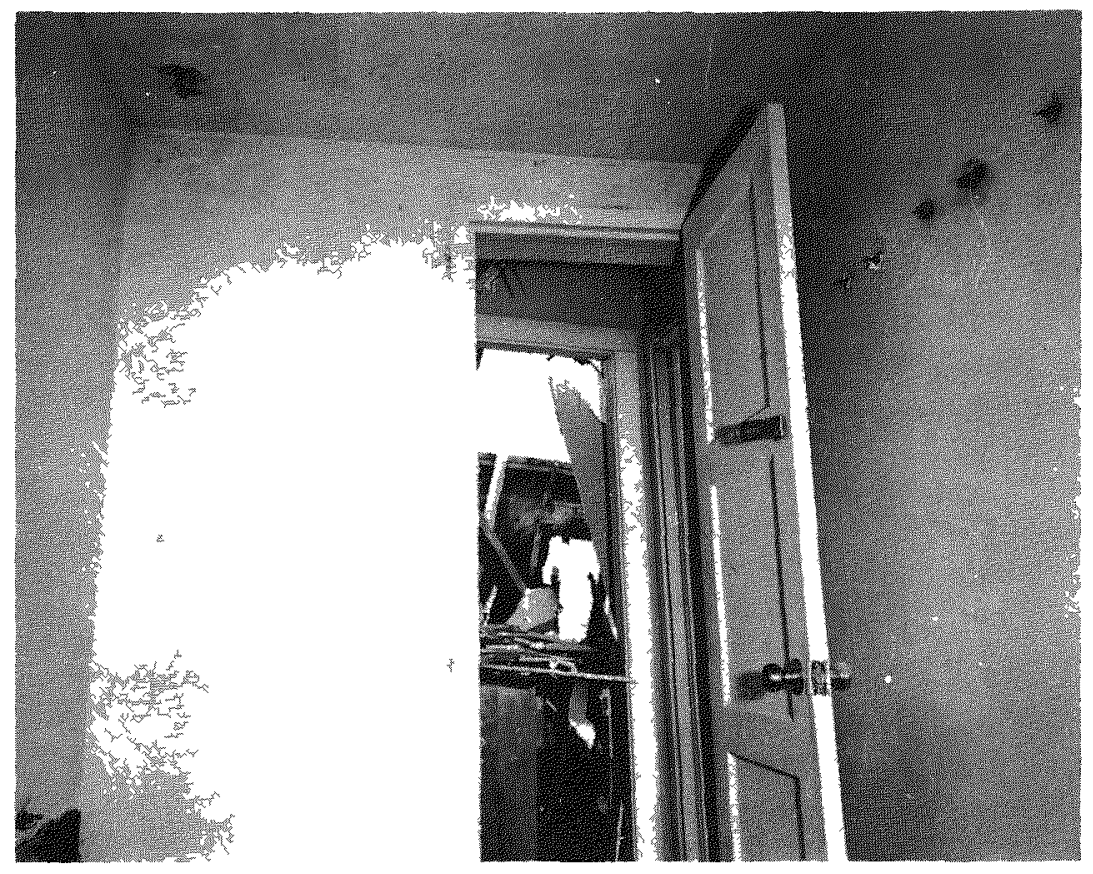

Fig. 5.11 - Concrete bathroom shelter, $4700 \mathrm{ft}$, open shot. 
CHAPTER 6

\section{SHELTER EVALUATION}

\subsection{NUCLEAR RADIATION PENETRATION}

It is anticipated that occupants of a group shelter would have rescue or other duties which iv ould require their being exposed to radiation outside the shelter in pursuance of these duties. Therefore underground personnel group shelters were designed to reduce radiation inside to not more than $25 \mathrm{r}$ since to design for an irradiation-to-sickness threshold would render occupants useless for emergency activities. It is not unreasonable to extend the 25-r limit criterion to family type shelters because present high-intensity fall-out weapons will subject shelter occupants to large amounts of radiation as the shelters are evacuated.

Gamma-radiation measurements inside the shelters can be converted directly into radiation effect on shelter occupants. For neutron radiation effect, however, the process is not so direct. Payne S. Harris (Project 39.7 ) has given the conversion factors to roentgen equivalent physical ( $\mathrm{rep}$ ) for sulfur. ${ }^{1}$ With his conversion factors and known percentages which each contribute to the total dose, lower and upper limits can be placed on equivalent radiation.

These values would apply to a biological system at ground level outside a shelter. But what happens to a man inside the shelter? We know from this experiment what happened inside and outside the shelters to the gold and sulfur neutrons only, but we have no information on the neutron energies between. Harris has found that the percentage of total flux in air contributed by each spectrum band remained essentially constant with distance. Without measurements between gold and sulfur energies, we can only assume that energy distribution within the neutron spectrum did not materially change in passing through earth, concrete, and other materials into the shelter. Thus the only available shelter evaluation consists in assuming that the conversions from gold and sulfur neutrons to rep in air are equally valid inside the shelters. The information in Table 6.1 is based on this assumption. Furthermore, in evaluating the utility type shelters, it is assumed that thermal neutrons inside the shelters are the same as those estimated outside and that the fast neutrons inside are the same proportion of those estimated outside as in the case of the measurement made in the near masonry shelter.

The roentgen equivalent man ( $\mathrm{rem}$ ) equivalent of neutron radiation is based on a relative biological effectiveness (RBE) of 1.6 (reference 2) from a reevaluation of Hiroshima and Nagasaki data by Harris. To evaluate the total exposure, curves from Hiroshima and Nagasaki 
Table 6.1-RADIATION SUMMARY FOR OPEN SHOT

\begin{tabular}{|c|c|c|c|c|c|c|c|c|c|c|}
\hline \multirow[b]{3}{*}{ Shelter } & \multirow{3}{*}{$\begin{array}{c}\text { Ground } \\
\text { distance, } \\
\text { ft }\end{array}$} & \multicolumn{4}{|c|}{ Neutrons $/ \mathrm{cm}^{2}$} & \multirow{3}{*}{$\begin{array}{l}\text { Average } \\
\text { gamma } \\
\text { inside, } r\end{array}$} & \multirow{2}{*}{\multicolumn{2}{|c|}{ Sick, \% }} & \multirow{2}{*}{\multicolumn{2}{|c|}{ Dead, \% }} \\
\hline & & \multicolumn{2}{|c|}{ Incident } & \multicolumn{2}{|c|}{ Local } & & & & & \\
\hline & & Fast & Thermal & Fast & Thermal & & Lower & $\overrightarrow{\text { Upper }}$ & Lower & Upper \\
\hline \multicolumn{11}{|l|}{ Underground group shelter } \\
\hline \multirow[t]{3}{*}{$34.3 \mathrm{a}-2$} & 1,050 & $1.52 \times 10^{42}$ & $3 \times 10^{13}$ & $4.01 \times 10^{8}$ & & 1.57 & 0 & 45 & & 0 \\
\hline & & & & $2.94 \times 10^{7}$ & $2.33 \times 10^{8}$ & & 0 & 0 & 0 & 0 \\
\hline & & & & $<2 \times 10^{8}$ & $7.75-8.85 \times 10^{8}$ & & 0 & 0 & 0 & 0 \\
\hline $34.3 b-2$ (fast-fili) & 1,050 & & & $1.62 \times 10^{8}$ & $1.03 \times 10^{11}$ & 50 & 75 & 100 & 15 & 100 \\
\hline $34.3 \mathrm{~b}=2$ (slow-fill) & 1,050 & & & $5.03 \times 10^{9}$ & $8.56 \times 10^{11}$ & 460 & 100 & 100 & 100 & 100 \\
\hline \multicolumn{11}{|l|}{ Basement exit shelters } \\
\hline $34.1 \mathrm{c}-1$ & 1,270 & $7.6 \times 10^{14}$ & $1.6 \times 10^{13}$ & $3.76 \times 10^{10}$ & $2 \times 10^{12}$ & 377 & 100 & 100 & 100 & 100 \\
\hline $34.1 c-2$ & 1,270 & & & $5.43 \times 10^{10}$ & $3.4 \times 10^{12^{2}}$ & 600 & 100 & 100 & 100 & 100 \\
\hline $34.1 \mathrm{~d}-1$ & 1,470 & $5.2 \times 10^{11}$ & $9.6 \times 10^{12}$ & $1.92 \times 10^{10}$ & $1.18 \times 10^{12}$ & 229 & 100 & 100 & 100 & 100 \\
\hline $34.1 \mathrm{~d}-2$ & 1,470 & & & $5.72 \times 10^{10}$ & $2.02 \times 10^{12}$ & 388 & 100 & 100 & 100 & 100 \\
\hline \multicolumn{11}{|l|}{ Utility type shelters } \\
\hline 34.1 e (precast) & 2,250 & $8.8 \times 10^{10}$ & $1.5 \times 10^{12}$ & $1.55 \times 10^{10^{b}}$ & $1.51 \times 10^{12}{ }^{b}$ & 2,650 & 100 & 100 & 100 & 100 \\
\hline $34.1 \mathrm{f}$ (poured) & 2,250 & & & $1.55 \times 10^{10^{b}}$ & $1.51 \times 10^{12 b}$ & 2,388 & 100 & 100 & 100 & 100 \\
\hline $34.1 \mathrm{~g}$ (masonry) & 2,250 & & & $1.55 \times 10^{10}$ & $1.51 \times 10^{12}$ & $7,250^{\mathrm{c}}$ & 100 & 100 & 100 & 100 \\
\hline $34.1 \mathrm{~h}$ (precast) & 2,750 & $3.1 \times 10^{10}$ & $5.1 \times 10^{11}$ & $5.45 \times 10^{8}$ & $5.1 \times 10^{11} \mathrm{~b}$ & 1,205 & 100 & 100 & 100 & 100 \\
\hline 34.11 (poured) & 2,750 & & & $5.45 \times 10^{8}$ & $5.1 \times 10^{11^{b}}$ & 1,075 & 100 & 100 & 100 & 100 \\
\hline 34.1 j (masonry) & 2,750 & & & $5.45 \times 10^{8}$ & $5.1 \times 10^{11^{b}}$ & 1,179 & 100 & 100 & 100 & 100 \\
\hline $34.1 \mathrm{k}$ (precast) & 3,750 & $4.4 \times 10^{9}$ & $6.9 \times 10^{10}$ & $7.75 \times 10^{8 \mathrm{~b}}$ & $6.9 \times 10^{10}$ & 277 & 85 & 95 & 25 & 60 \\
\hline 34.11 (poured) & 3,750 & & & $7.75 \times 10^{8 b}$ & $6.9 \times 10^{10^{b}}$ & 275 & 85 & 95 & 25 & 60 \\
\hline $34.1 \mathrm{~m}$ (masonry) & 3,750 & & & $7.75 \times 10^{8 b}$ & $6.9 \times 10^{10^{3}}$ & 226 & 80 & 90 & 20 & 50 \\
\hline Reinforced-conerete & 4,700 & $8.8 \times 10^{8}$ & $1.1 \times 10^{10}$ & & & 51 & $<5$ & 85 & 0 & 35 \\
\hline bathroom & 10,500 & $1.0 \times 10^{5}$ & $5.8 \times 10^{5}$ & & & 0.24 & 0 & 0 & 0 & 0 \\
\hline Reinforced-conerete & 5,500 & $2.4 \times 10^{8}$ & $2.7 \times 10^{9}$ & & & 1.77 & 0 & 20 & 0 & 0 \\
\hline basement room & 7,800 & $6.2 \times 10^{6}$ & $5.2 \times 10^{7}$ & & & 0.20 & 0 & 0 & 0 & 0 \\
\hline \multirow[t]{4}{*}{ Basement corner-room } & 4,700 & $8.8 \times 10^{8}$ & $1.1 \times 10^{10}$ & & & 28 & 0 & 85 & 0 & 30 \\
\hline & 5,500 & $2.4 \times 10^{8}$ & $2.7 \times 10^{9}$ & & & 21 & 0 & 25 & 0 & 0 \\
\hline & 7,800 & $6.2 \times 10^{6}$ & $5.2 \times 10^{7}$ & & & 1.22 & 0 & 0 & 0 & 0 \\
\hline & 10.500 & $1.0 \times 10^{5}$ & $5.8 \times 10^{5}$ & & & 0.13 & 0 & 0 & 0 & 0 \\
\hline \multirow[t]{4}{*}{ Basement lean-to shelter } & 4,700 & $8.8 \times 10^{8}$ & $1.1 \times 10^{10}$ & & & 6.7 & 0 & 85 & 0 & 30 \\
\hline & 5,500 & $2.4 \times 10^{8}$ & $2.7 \times 10^{9}$ & & & 2.48 & 0 & 20 & 0 & 0 \\
\hline & 7,800 & $6.2 \times 10^{6}$ & $5.2 \times 10^{7}$ & & & 0.67 & 0 & 0 & 0 & 0 \\
\hline & 10,500 & $1.0 \times 10^{5}$ & $5.8 \times 10^{5}$ & & & $>0.10$ & 0 & 0 & 0 & 0 \\
\hline
\end{tabular}

${ }^{2}$ Estimated as same percentage of incident neutron flux as Station $34.1 \mathrm{~d}-2$.

Estimated as same percentage of incident neutron flux as measured for station $34.1 \mathrm{~g}$.

Average of only two dosimeters, both of which read high because of relatively long postshot contact with the ground; $2420 \mathrm{r}$ used for calculations in table. 
of percentage affected vs exposure in roentgens were obtained from Harris and are used here (Fig. 6.1).

The closed underground personnel shelter at $1050 \mathrm{ft}$ probably provided satisfactory protection from radiation. The high reading on a sulfur detector at the end of this shelter away from the entrance on open shot prevents a positive conclusion that the shelter is satisfactory. Certainly it would not be considered satisfactory if 45 per cent of the occupants were so sick as to be incapacitated.

None of the basement exit and utility type shelters provided satisfactory radiation protection.

Indoor family type shelters were satisfactory beyond 1 mile. There is some doubt about the three indoor shelters at $4700 \mathrm{ft}$. It should be borne in mind that the basement lean-to and the basement corner-room shelter were located in the best possible position with respect to the burst point. If they had been located on the opposite side of the basement, it is likely that total exposure would be closer to that of the incident fast-neutron radiation, and the effect would be close to that given in the last two columns of Table 6.1. Since the neutron flux inside the shelters was not measured, the effect as tested probably was close to the lower limit in the last two columns of the table.

The amount of shielding provided by the shelters against prompt gamma radiation is significant. Although the energy of prompt gamma radiation is generally higher than that of fallout radiation and the shielding provided is more effective against fall-out radiation, the shield $m$ ing against prompt radiation may be used as a lower limit of the shielding which woula be provided against fall-out. Table 6.2 gives the ratios of gamma radiation (as measured outside the shelters to that inside). In general, shielding efficiency of a particular design decreases with distance from the source.

With the exception of the reinforced-concrete shelter, basement shelters were not expected to provide significant amounts of radiation protection over that provided by the basement. To evaluate that portion of the protection provided by the basement and that furnished by the shelter, the ratio of the average gamma radiation inside the basement to that inside the shelter is also given in Table 6.2.

Measurements made inside the open (biomedical) shelter have particular interest to the defense problem. There are many existing structures which will be considered as emergency shelters. Few of these are completely closed. The protection provided by such an open shelte $c$ can be indicated by the results of measurements made in the biomedical shelters. Results of measurements made in similar shelters constructed by the military on other thail the operi shot ${ }^{3}$ can be used to increase the precision with which the protection provided by existing structures can be estimated.

Perhaps the most significant conclusion which can be reached is that complete protection can be provided by a closed shelter if $\rho 1=2800$, where $\rho$ is the density of intervening material in pounds per cubic feet and 1 is the number of line-of-sight feet of the material penetrated. Below $\rho 1=2800$, the shielding factor decreases rapidly. The value given is set by fast neutrons and is about twice that required for gamma radiation or slow neutrons. Because of the lower energy, even lower values would be required for fall-out radiation where no prompt radiation could be expected. To date, no significant amount of full-scale data has been obtained on shielding from fall-out. Because of the advent of weapons whose fall-out covers large areas, there is a great need for information on shielding from high-intensity fall-out.

\subsection{THERMAL CONVECTION}

Measured temperatures were all less than had been anticipated. Although it is possible that they were actually less, it is also possible that there was a steep temperature gradient away from the cool concrete walls of the biomedical shelter. The whistle temperature gauge was flush-mounted in the wall and was measuring a small amount of air from near the wall. If it had sampled air a greater distance from the wall, a higher temperature might have been recorded. 


\section{2}

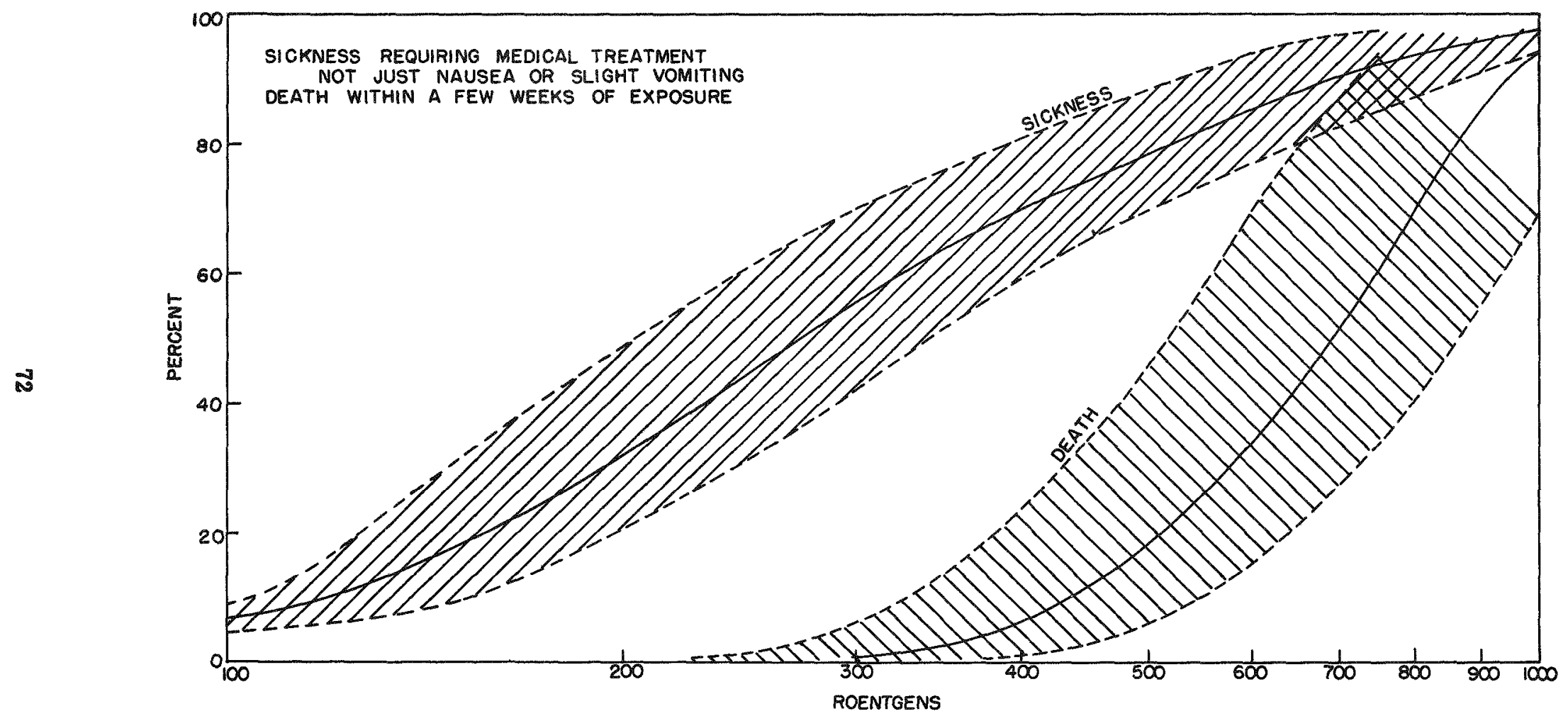

Fig. 6.1-Percentage affected vs exposure. 
Table 6.2-RATIO OF PROMPT GAMMA RADIATION INSIDE SHELTERS TO THAT OUTSIDE

\begin{tabular}{|c|c|c|}
\hline Shelter & $\begin{array}{l}\text { Ratio: incident } \\
\text { to average inside }\end{array}$ & $\begin{array}{c}\text { Ratio: average in basement } \\
\text { to average in shelter }\end{array}$ \\
\hline & Early shot & \\
\hline \multicolumn{3}{|l|}{ Underground personnel } \\
\hline 1 & 25,000 & \\
\hline 2 (fast-fill) & 710 & \\
\hline $2($ slow-fili) & 77 & \\
\hline \multicolumn{3}{|l|}{ Basement exit } \\
\hline 3 & 140 & \\
\hline 4 & 62 & \\
\hline \multirow[t]{2}{*}{5} & 53 & \\
\hline & Open shot & \\
\hline \multicolumn{3}{|l|}{ Underground personnel } \\
\hline $34.3 a-2$ & 11,000 & \\
\hline $34.3 \mathrm{~b}-2$ (fast $-\mathrm{fill})$ & 350 & \\
\hline $34.3 \mathrm{~b}-2($ slow $-\mathrm{fill})$ & 38 & \\
\hline \multicolumn{3}{|l|}{ Basement exit } \\
\hline $34.1 \mathrm{c}-1$ & 93 & \\
\hline $34.1 \mathrm{c}-2$ & 58 & \\
\hline $34.1 \mathrm{~d}-1$ & 103 & \\
\hline $34.1 \mathrm{~d}-2$ & 60 & \\
\hline \multicolumn{3}{|l|}{ Utility type } \\
\hline 34.1 e (precast) & 1.5 & \\
\hline $34.1 f$ (poured) & 1.7 & \\
\hline \multicolumn{3}{|l|}{$34.1 \mathrm{~g}$ (masonry) } \\
\hline $34.1 \mathrm{~h}$ (precast) & 1.8 & \\
\hline 34.1 i (poured) & 2.0 & \\
\hline 34.1 j (masonry) & 1.9 & \\
\hline $34.1 \mathrm{k}$ (precast) & 2.3 & \\
\hline 34.11 (poured) & 2.3 & \\
\hline $34.1 \mathrm{~m}$ (masonry) & 2.8 & \\
\hline \multicolumn{3}{|c|}{ Reinforced-concrete bathroom } \\
\hline $4,700 \mathrm{ft}$ & 3.8 & \\
\hline $10,500 \mathrm{ft}$ & 1.2 & \\
\hline \multicolumn{3}{|c|}{ Reinforced-concrete basement room } \\
\hline $5,500 \mathrm{ft}$ & 40 & 8.7 \\
\hline $7,800 \mathrm{ft}$ & 26 & 6.5 \\
\hline \multicolumn{3}{|l|}{ Basement corner-room } \\
\hline $4,700 \mathrm{ft}$ & 6.8 & 0.9 \\
\hline $5,500 \mathrm{ft}$ & 3.4 & 0.7 \\
\hline $7,800 \mathrm{ft}$ & 4.2 & 1.1 \\
\hline $10,500 \mathrm{ft}$ & 2.3 & 1.3 \\
\hline \multicolumn{3}{|l|}{ Basement lean-to } \\
\hline $4,700 \mathrm{ft}$ & 25 & 1.1 \\
\hline $5,500 \mathrm{ft}$ & 29 & 2 \\
\hline $7,800 \mathrm{ft}$ & 7.7 & 2 \\
\hline $10,500 \mathrm{ft}$ & $\mathbf{3 . 0}$ & 2 \\
\hline
\end{tabular}


There is some literature on the effect of radiant thermal energy of short duration on the skin of humans and animals, but little information exists on the effect of heat transfer by convection to skin from air with short-duration thermal transients. Extrapolating information from Buettner $r^{4}$ to shorter durations, assuming that pain involves a skin temperature of 42 to $45^{\circ} \mathrm{C}$ and third-degree burns result from four times the pain dosage and that the effect of heat transferred to the skin by convection is no different than that transferred by radiation, it is possible to estimate thermal convection effects. This would indicate that both measured temperatures and expected higher temperatures were insufficient to burn human skin. Despite this, some experimental animals showed singeing and scorching of fur. A few had minor burns on exposed skin. Both skin burn and singeing were functions of the location and orientation of the animals within the shelter. In the fast-fill room the burning and singeing pointed to a source entering the door and rotating counterclockwise in the room; that is, the animal beside gauge P-7 (Fig. 1.19) was singed as if the heat were coming from the direction of gauge P-6. This indicates convection or dust carried by the air-transferred heat to skin and fur. In the slow-fill room where thermal effects were directional, the sources appear to be planar, originating from the wall in which gauge $\mathrm{P}-10$ was located.

The only singed animals located near a temperature gauge were those in the open shot shelter where peak measured temperatures were also the highest measured (over $300^{\circ} \mathrm{C}$ ). In this respect measured temperatures were consistent with the results on animals. At some of the other locations, animals were subjected to higher temperatures than those measured.

The temperatures cannot be inferred from the results on animals until experimental work is done which points out the temperature-time parameters required to singe fur or burn skin by convection and/or dust. This type of information would be of value to civil defense in determining the type of thermal casualties which might occur for personnel protected by makeshift shelter. It should be kept in mind, however, that for weapons of the type tested on the open shot persons who were thermal casualties would also be casualties from nuclear radiation.

\subsection{BLAST EFFECTS AND STRUCTURAL DAMAGE}

Underground group personnel shelters appear to provide sufficient protection for occupants against blast and missiles for peak incident pressures of 100 psi or less. Antiblast closures operated successfully to prevent entry of damaging overpressures. Doors and escape hatches, if not as originally operable, were capable of being jacked open from the inside. Structurally, the shelters proved the validity of their design. Shelter displacement ( $1.7 \mathrm{in}$. downward) was insufficient to cause harm to occupants.

An unbalance between interior and exterior pressure resulting from failure of the doors caused the severe interior structural damage to basement exit shelters. Possibly a revised door design would reduce the pressure inside enough to offer occupants refuge from blast effects.

Of the three utility types (masonry, precast, and poured-in-place), the poured-in-place reinforced-concrete shelter seems to have the most resistance to blast and the reinforcedmasonry shelter the least. Strengthening of the interior door and its connections is required. Rebound latches are adequate as tested.

Basement corner-room, lean-to, and reinfor ced-concrete shelters provide protection from missiles and debris and the effects of a sharp shock, but they do not significantly alter the maximum overpressure within the basement. Since there was no debris loading, the relative effectiveness of these sheiters under such loading cannot be evaluated from these tests.

At the distances tested, reinforced bathroom shelters would have provided adequate protection from blast and missiles.

\subsection{GENERAL}

No shelter design should be based only on a single effect. A design based on a given standard either conservative or marginal for a single effect may be vulnerable to another at 
the same or another yield. Consider the underground group shelter as an example, disregarding thermal effects as insignificant. That shelter gave satisfactory blast protection from 100 psi from a weapon with a yield of approximately $30 \mathrm{kt}$. Using the blast scaling laws of The Effects of Atomic Weapons, ${ }^{5}$ one obtains the straight line in Fig. 6.2, which represents the boundary between damage and no damage if one assumes no increase in blast damage with an increase in shock wave duration with yield. Should there be an increase in damage with an increase in positive-phase duration, the line would curve slightly upward to the right.

The uncertainties raised by the neutron measurements inside this shelter make it unwise to recommend that it be considered safe for any more than the incident flux to which it was subjected. Using these values and their mean free paths from Fig. 2.2, the apparent neutron source strength can be computed. ${ }^{5}$ This can then be scaled to other yields and distances as shown in Fig. 6.2 for both fast and slow neutrons. Gamma radiation has not been considered because interior measurements show it is not important for this shelter. At present there is no satisfactory unclassified means of scaling the effect of gamma radiation.

Figure 6.2 shows that if the design had been predicted on neutron effect alone the shelter would have furnished inadequate protection from blast from larger yield weapons. The design was a balanced design for a 30-kt weapon but not for larger yields. Such a plot as Fig. 6.2, if prepared for each shelter design, shows the designer how adequate is the protection provided and allows the user to decide which shelter he will build by comparing similar plots for a series of shelters and weighing these against the cost of each design. Only in this way can the best protection per unit expenditure be resolved.

Access to shelters has always provided a problem for designers. When a shelter has a door or other device to keep out the effects, a decision involves the possibility of closing the door before all those to be protected are inside and the necessity of reopening the door and subjecting those inside to additional risk. This problem of access combined with the difficulties of adequately ventilating a closed shelter has pointed up the desirability of having a biologically acceptable open sheiter.

All shelters tested on Operation Teapot were designed as closed shelters. Neither access nor ventilation is as important for family type shelters as for group shelters because the family goes into the shelter together, the number of people is small, the ventilation required is correspondingly small, and ordinarily family type shelters are designed to survive at relatively great distances. Group shelters on the other hand protect more people at closer distances. A closed shelter can be made to provide complete protection, whereas the consideration of an open shelter implies acceptance of some degree of hazard. For an open shelter prompt radiation can be decreased or eliminated by sufficient earth cover and fall-out radiation and thermal effects by attenuation in long passages. Blast overpressure is more complex, and its attenuation is a function of the geometry of each shelter design. An appendix of Report WT-1161 points out how the overpressures inside a shelter may be obtained without going to full-scale tests. Once the overpressure inside an open shelter is determined, one is faced with the uncertainty of its biological result. Until more is known about the amount of overpressure to which a person may be subjected without impairing his ability to carry out specified emergency assignments, the shelters protecting emergency crews should be designed as closed shelters.

The use of a low radiation dosage ( $25 \mathrm{r}$ ) as a design criterion has been mentioned earlier and is necessitated by the need for emergency crews to have an available reserve for their postshot activities and for other people to have a reserve which they can use in the postshot period when they may be living in an area heavily irradiated by fall-out. Because of the ease with which additional protection is provided, there are some worth while arguments in favor of having no allowable radiation as a design criterion. ${ }^{6}$ In the redesign of the group shelter (see Appendix A), a greater emphasis has been given to the comfort of the occupants. Benches and bunks have been provided, and the redesign calls for sanitary facilities. An emergency water supply of 10 gal per occupant is specified. Each of these attests to excellent recognition of the possibility of occupants being subjected to enforced occupancy for uncertain periods of time by heavy fall-out radiation outside. Because the same possibility pertains to family type shelters, these same considerations for the comfort of the occupants should not be overlooked in the design of smaller shelters. 


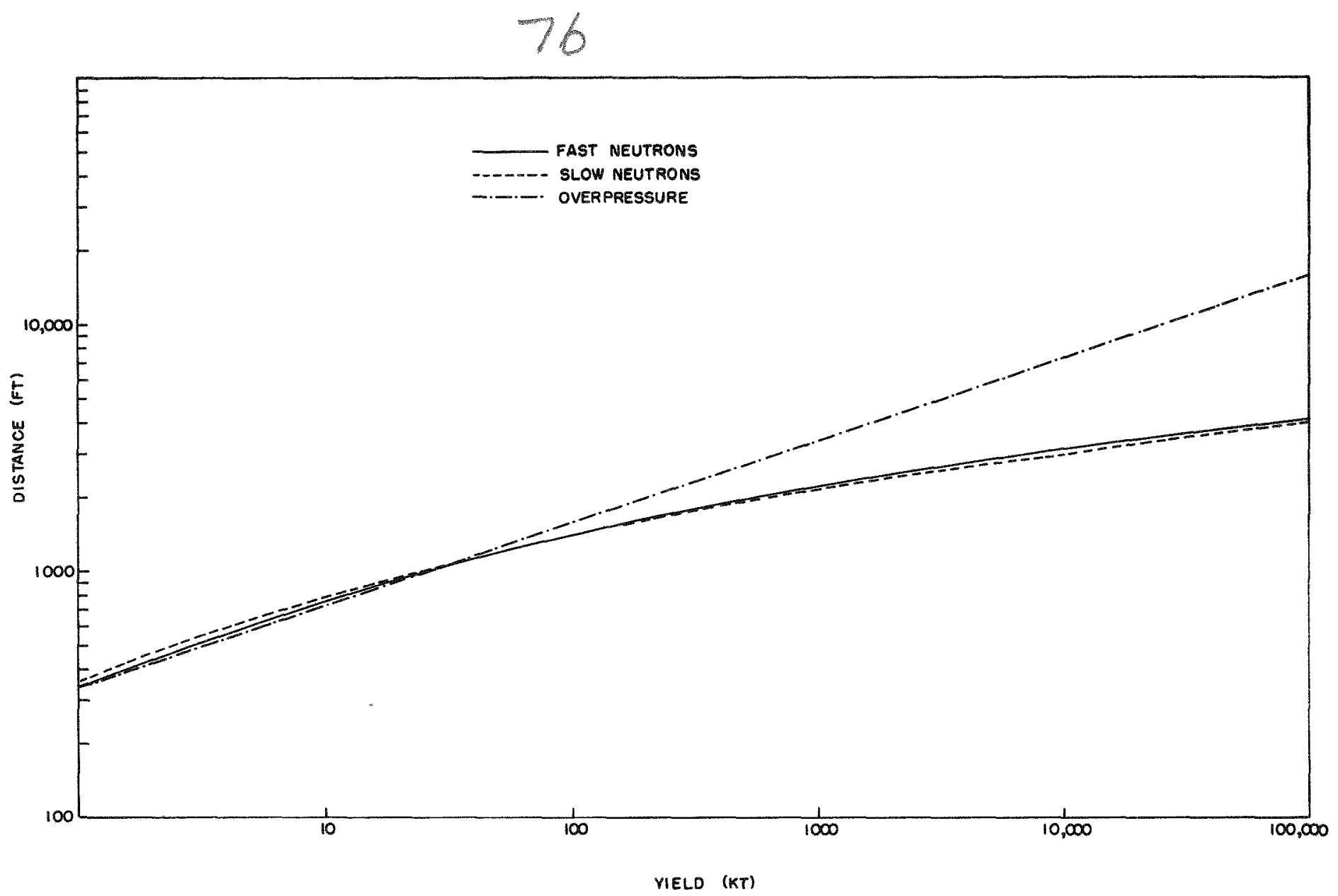

Fig. 6.2-Weapons effects radil for various yields. 


\section{RE FERENCES}

1. P. S. Harris, Physical Measurement of Neutron and Gamma Radiation Dose from High Neutron Yield Weapons and Correlation of Dose With Biological Effect, Operation Teapot Report, ITR-1167 (to be superseded by WT-1167).

2. P. S. Harris, Biological Effectiveness of Nuclear Radiation from Fission Weapons, Report LA-1987, August 1955 (classified).

3. J. R. Hendrickson et al., Shielding Studies, Operation Teapot Report, WT-1121.

4. Konrad Buettner, Effects of Extreme Heat on Man. I. Protection of Man Against Conflagration Heat, Report No. 1, USAF School of Aviation Medicine, Randolph Field, Tex., February 1950.

5. S. Glasstone, ed., The Effects of Atomic Weapons, U. S. Government Printing Office, Washington, D. C., 1950.

6. W. E. Strope, Radiological Defense Measures As a Countermeasure System, USNRDL-TR74, Feb. 15, 1956. 


\section{CHAPTER 7}

\section{CONCLUSIONS AND RECOMMENDATIONS}

\subsection{CONCLUSIONS}

\subsubsection{Radiation Penetration}

The closed underground group personnel shelters provided satisfactory protection from radiation. One unexplainably high reading from a fast-neutron detector casts some doubt on this conclusion. These shelters had been designed to reduce radiation to at least $25 \mathrm{r}$.

Using these same design criteria, the basement shelters and the utility type shelters did not provide satisfactory radiation protection. The reinforced-concrete bathroom shelter at $4700 \mathrm{ft}$ was also unsatisfactory.

The reinforced-concrete bathroom shelter at 10,500 ft and the indoor basement shelters beyond $4700 \mathrm{ft}$ provided satisfactory protection against radiation. At $4700 \mathrm{ft}$ the indoor basement shelters, except the lean-to, had exposures in excess of $25 \mathrm{r}$. If the lean-to had been built on the opposite side of the basement or extended higher, it might have received a larger amount of radiation.

\subsubsection{Thermal Convection}

Temperatures inside the open biomedical shelter were less than had been predicted. Although this shelter would not ordinarily be used as an open shelter, it has shown that occupants of an open similarly designed shelter at this distance would sustain some burns.

\subsubsection{Blast Effects and Structural Damage (Open Shot)}

The antiblast closure unit in the closed underground personnel shelter operated satisfactorily and prevented damage to the diffusion-board installation inside the shelter.

The reinforced-concrete door of the underground personnel shelter suffered superficial damage which a redesign should correct. The antiblast closure operated satisfactorily and prevented any overpressure within the shelter proper. The shelter, as tested, would provide protection from missiles and overpressure.

The basement exit shelters would not have furnished effective protection against blast of the overpressure levels to which they were subjected.

Experimental animals in the closed basement exit shelters at a lower overpressure on an earlier shot indicate that occupants of the shelters would not have become fatalities but probably would have been injured or subjected to more than an unobjectionable amount of discomfort. It is doubtful that the closed shelter should be expected to provide protection from overpressures in excess of 10 psi. 
The indoor family type 'shelters provided adequate protection from missiles and debris under the conditions tested. The concrete bathroom shelter reduced the overpressure by a significant amount, but in the other types the overpressure inside the shelter was about the same as in the incident wave. Although no measurement was made, it is believed that the basement concrete room shelter would have reduced the overpressure in much the same manner as the concrete bathroom shelter.

\subsection{RECOMMENDA TIONS}

\subsubsection{Radiation Penetration}

Every opportunity should be taken to measure radiation inside and outside of structures to determine shielding factors. Particular emphasis should be given to measuring the full neutron spectrum inside and outside.

Only the closed group personnel shelters and the indoor family type shelters (other than the bathroom shelter at $4700 \mathrm{ft}$ ) should be considered satisfactory as tested.

\subsubsection{Thermal Convection}

Experiments should be performed which would relate the thermal effects of transient convection to the large amount of information on effects of thermal radiation on the skin.

The reliability of the temperature whistle gauge should be improved.

\subsubsection{Blast Effects and Structural Damage}

Bolts on the rebound locks on the sliding concrete door of the underground personnel shelter should be increased in diameter. The door should be redesigned so that it seats just at the end of the run and so that it extends over the wheels to provide protection against missiles. ${ }^{2}$

The basement exit shelters require a redesign of the blast door, rebound lock, and retaining walls to withstand incident overpressures in excess of 10 psi. The inner door should be eliminated.

Although with the modifications recommended below they would provide satisfactory protection from blast, no other shelter, as tested, provided less protection from nuclear radiation than the aboveground utility type shelters. Unless redesigned to carry a significant amount of earth cover with a radiation baffle arrangement at the entrance, it is recommended that the concept of an aboveground shelter of this type be dropped. If redesigned, the inner door of the aboveground utility shelters should be eliminated, and heavier rebound latches should be provided with a more positive attachment to the door than screws.

Although the indoor family type shelters provided adequate blast protection under the conditions tested, it is doubtful if the protection would be adequate against high-level fall-out radiation. Therefore it is recommended that attention be given to the development of the simple shelter types which would give protection from fall-out and still provide the same blast protection as those shelters tested on Operation Teapot.

${ }^{a}$ Note in Appendix A that these recommendations have been incorporated in the final design. 
APPENDIX A

\section{DESIGN OF AN UNDERGROUND PERSONNEL SHELTER}

By

Edward Laing

Ammann \& Whitney, Consulting Engineers 


\section{NOMENCLATURE}

$\mathbf{R}=$ resistance at support

$\mathbf{L}=$ length

$\mathbf{M}_{\mathrm{Q}}=$ moment of force at center line

$\mathrm{M}_{\mathrm{S}}=$ moment of force at end

$\mathrm{ULT}=$ ultimate

$p=$ pressure per unit area

$f_{\text {dc }}^{\prime}=$ dynamic ultimate unit stress of concrete

$f_{c}^{\prime}=$ static ultimate unit stress of concrete

$f_{d y}=$ dynamic unit stress of steel at yield

$\mathrm{f}_{\mathrm{y}}=$ static unit stress of steel at yield

$\mathrm{b}=$ breadth or width

$\mathrm{d}=$ over-all depth

$\mathrm{t}=$ thickness

$\mathrm{V}=$ total shear

$j=$ ratio of distance between resultants of compressive and tensile stresses to effective depth

$\mathrm{v}=$ unit shear

$\mathbf{P}=$ load

$e=$ eccentricity of application of load

$\mathrm{A}_{\mathrm{S}}=$ area of steel

$a=$ coefficient used in determining the area of steel

$\mathrm{x}_{\mathrm{yp}_{1}}=$ centerline deflection at first yield (see resistance vs deflection curve, Sec. A.7.2)

$\mathrm{X}_{\mathrm{yp}_{2}}=$ centerline deflection at second yield point (see Sec. A.7.2)

$\mathbf{E}=$ modulus of elasticity

$I=$ moment of inertia

$\mathrm{K}=\mathrm{kip}$

$\mathrm{k}=$ stiffness

$\mu=$ Poisson's ratio for concrete 


\section{APPENDIX A}

\section{DESIGN OF AN UNDERGROUND PERSONNEL SHELTER}

\section{A.1 GENERAL}

The underground personnel shelter was designed to provide protection against the blast effects of a nuclear weapon detonated at a distance that would produce a relatively long-duration surface overpressure of $100 \mathrm{psi}$ above the shelter. The earth cover and arrangement of the entrance corridor were chosen to provide reduction of the prompt radiation dosage in the shelter to a safe level. A suitable ventilation system was provided to ensure protection against residual radiation and possible bacteriological or gas contamination.

The shelter area is separated from the entrance corridor by an airtight steel-plate door. A blast door at the surface was necessary because a feasible labyrinth configuration could not be found which would provide a substantial reduction of the reflected pressures at the end of the corridor for all the possible orientations. It was decided that the best type of entrance door was one that would be flush with the ground surface and therefore loaded by side-on pressures rather than the higher intensity reflected pressures to which a conventional vertical type door would be subjected. The horizontal door is mounted on commercial type wheels and rails and may be rolled into position to close off the shelter corridor. A modified commercial jack, which is mounted on the corridor ceiling, provides for opening of the door if it should become damaged or jammed by debris.

An emergency exit which consists of a sand-filled vertical shaft above a steel-plate trap door is located in one corner of the shelter area. The trap door is opened by pulling down on a lever mechanism mounted in the ceiling. The sand drops into the shelter, leaving an open exit to the surface. A vertical steel ladder is built into the wall for ascending through the shaft to the surface.

\section{A.2 DESIGN BLAST LOADING}

The roof slab was designed to withstand a constant overpressure of 100 psi with an instantaneous time of rise. The upward blast pressure on the floor slab was taken as $\mathbf{7 5}$ psi. The estimated blast pressures on the walls were not critical since the strength of the wall was determined by the requirements of the roof and floor slabs.

\section{A.3 STRENGTH CRITERIA}

The entire structure was designed for dynamic behavior using ultimate strength theory. ${ }^{1}$

Concrete was required to have a minimum compressive strength of 4000 psi at 28 days. Reinforcing steel was intermediate grade with deformations conforming to ASTM Designation A305-50T, with a minimum specified yield point of $40,000 \mathrm{psi}$ and a probable average of 
$50,000 \mathrm{psi}$. The latter figure was used for design. The structural steel conformed to ASTM Designation A7-50, with a minimum specified yield point of 33,000 psi and a probable average value of approximately $40,000 \mathrm{psi}$. The figure of $40,000 \mathrm{psi}$ was used for design. The dynamic design tensile and compressive yield stresses for steel and the dynamic ultimate compressive stress for concrete were increased over the static values to account for the rapid strain rates $^{2}$ caused by the blast loading.

\section{A.4 DESIGN}

Most of the structure was designed for plastic deformation. The sliding door at the entrance and the trap door at the escape hatch were designed elastically to avoid excessive deformation which could result in jamming.

The sliding door is a $9 \mathrm{ft} 6 \mathrm{in}$. by $3 \mathrm{ft} 9 \mathrm{in}$. by $8 \mathrm{in}$. reinforced-concrete slab in a structural steel channel frame, subdivided into three two-way panels by structural steel wide-flange sections. This arrangement gave a minimum slab thickness and weight. To provide against negative phase pressures, a latching device consisting of four bolts passing through the door and secured to the corridor walls was incorporated in the design.

The 3- by 3-ft steel-plate trap door below the emergency escape hatch is composed of a $1 / 2$-in. steel plate supported by three structural steel channels.

The roof slab, floor slab, and longitudinal side walls of the shelter proper were designed as one-way panels. The end walls were designed as two-way panels using crack line theory. ${ }^{3}$ Typical design computations are shown in Sec. A.7 for the roof slab of the shelter.

\section{A.5 ANALYSES}

The analyses of the various members of the structure which are exposed to blast consists in the solution of the equation of motion, $F-R=m_{e} \ddot{x}$; where $F$ is the applied blast force, $R$ is the internal resistance of the structural member, $m_{e}$ is the mass of an equivalent one-degreeof-freedom system, ${ }^{4}$ and $\ddot{x}$ is the acceleration of the mass.

This equation of motion can be readily solved by any of several numerical-integration ${ }^{5}$ methods. The numerical method illustrated in Sec. A.7.2 for the analyses of the roof slab of the shelter is the "trial-and-error-solution" described in reference 2.

\section{A.6 ARCHITECTURAL AND STRUCTURAL DRAWINGS}

The architectural and structural drawings for the personnel shelter are shown in Figs. A.1 through A.5. The structure shown on these drawings, except for the architectural, is essentially the same as the as-built structure. Several modifications and additions-have been made on these drawings subsequent to the test of the shelter. The most significant of these modifications and additions are:

1. Toilet added.

2. Wooden airtight door between exhaust air chamber and intake air chamber replaced with a steel-plate airtight door.

3. Concrete parapet framing around rolling door strengthened.

4. Angle guards for protection of wheels of rolling door added.

5. Size of rebound bolt assembly in rolling coor increased.

6. Change in capacity from 50 to 30 persons. 

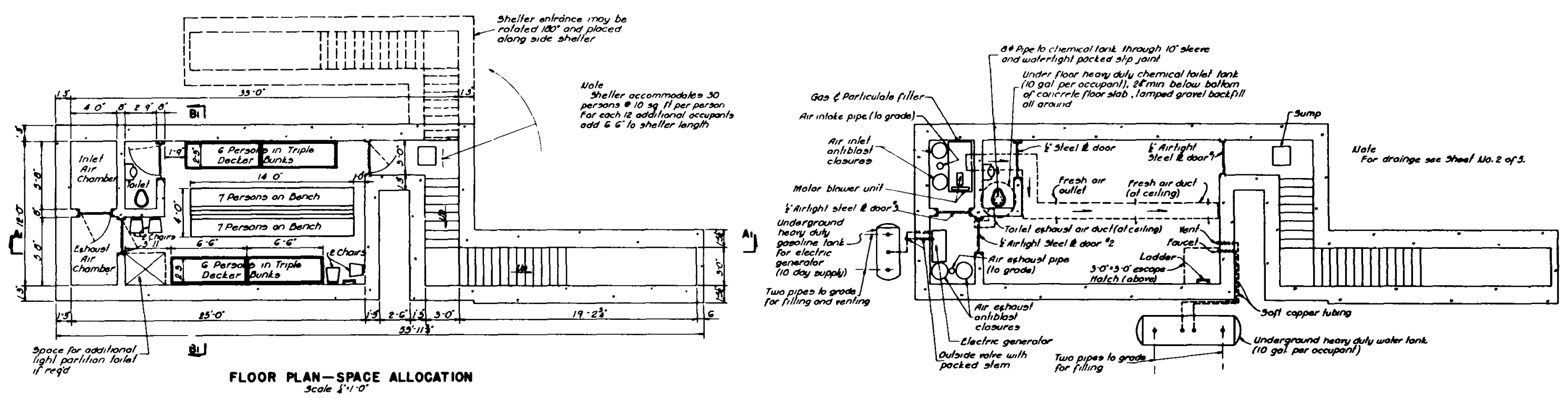

FLOOR PLAN-MECHAMCAL EOUPMENT LAYOUT

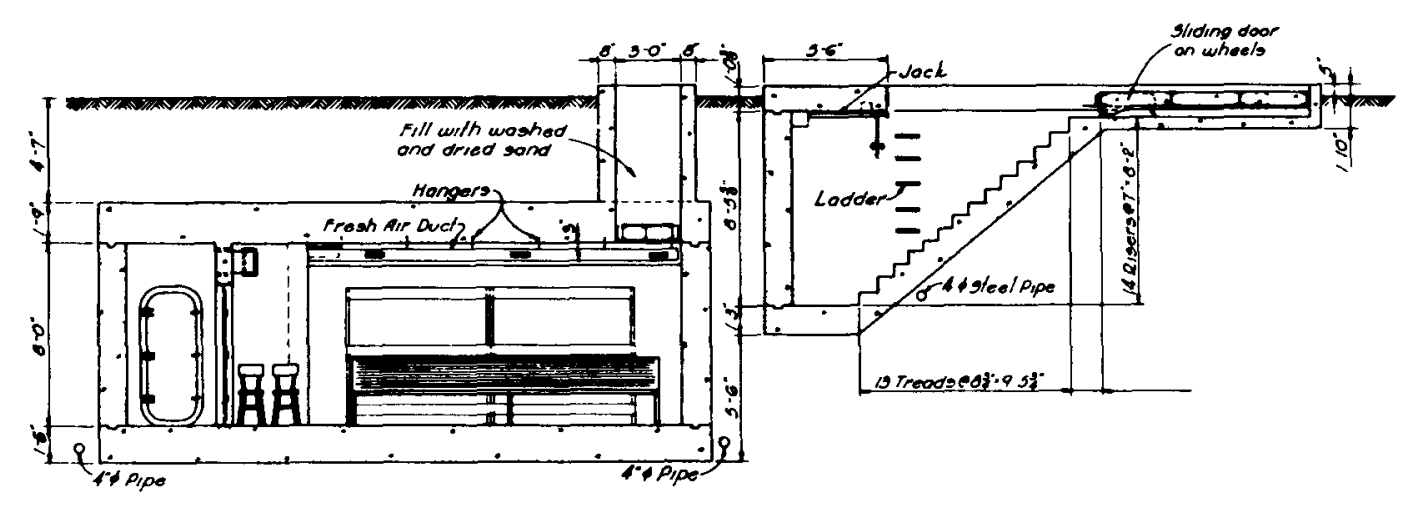

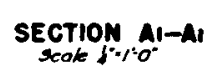

Fig. A.1 - Architectural plans and sections, underground personnel shelter.

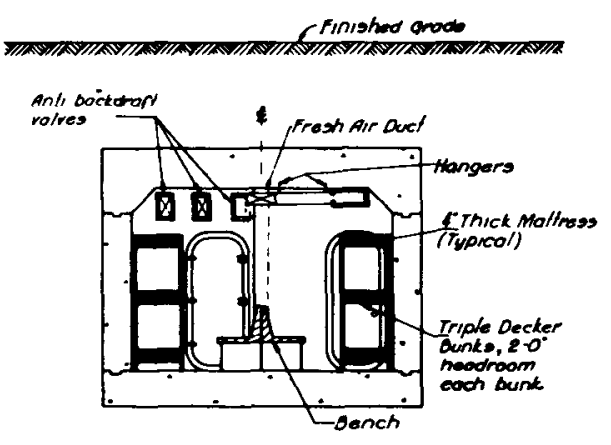

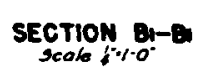

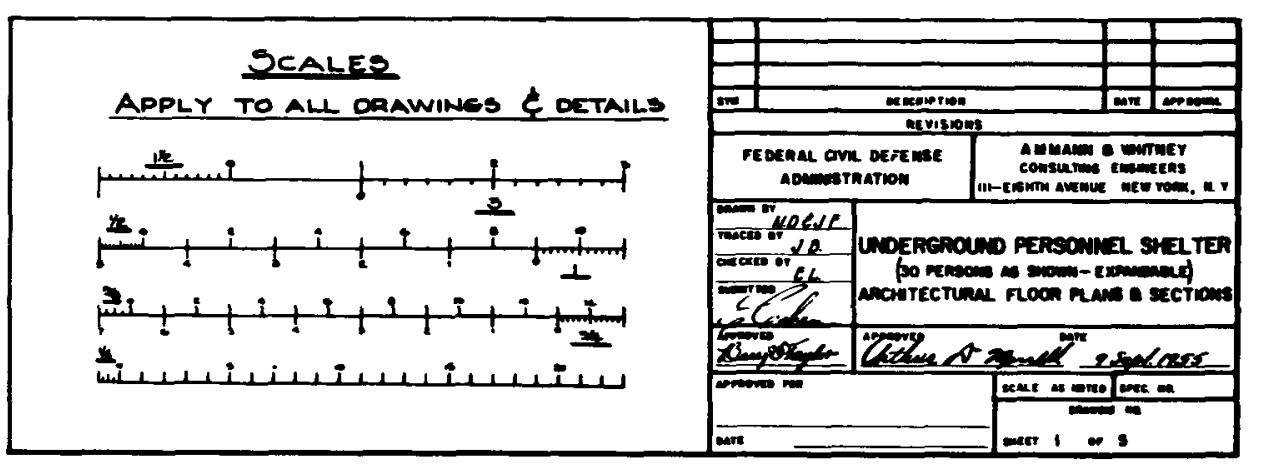



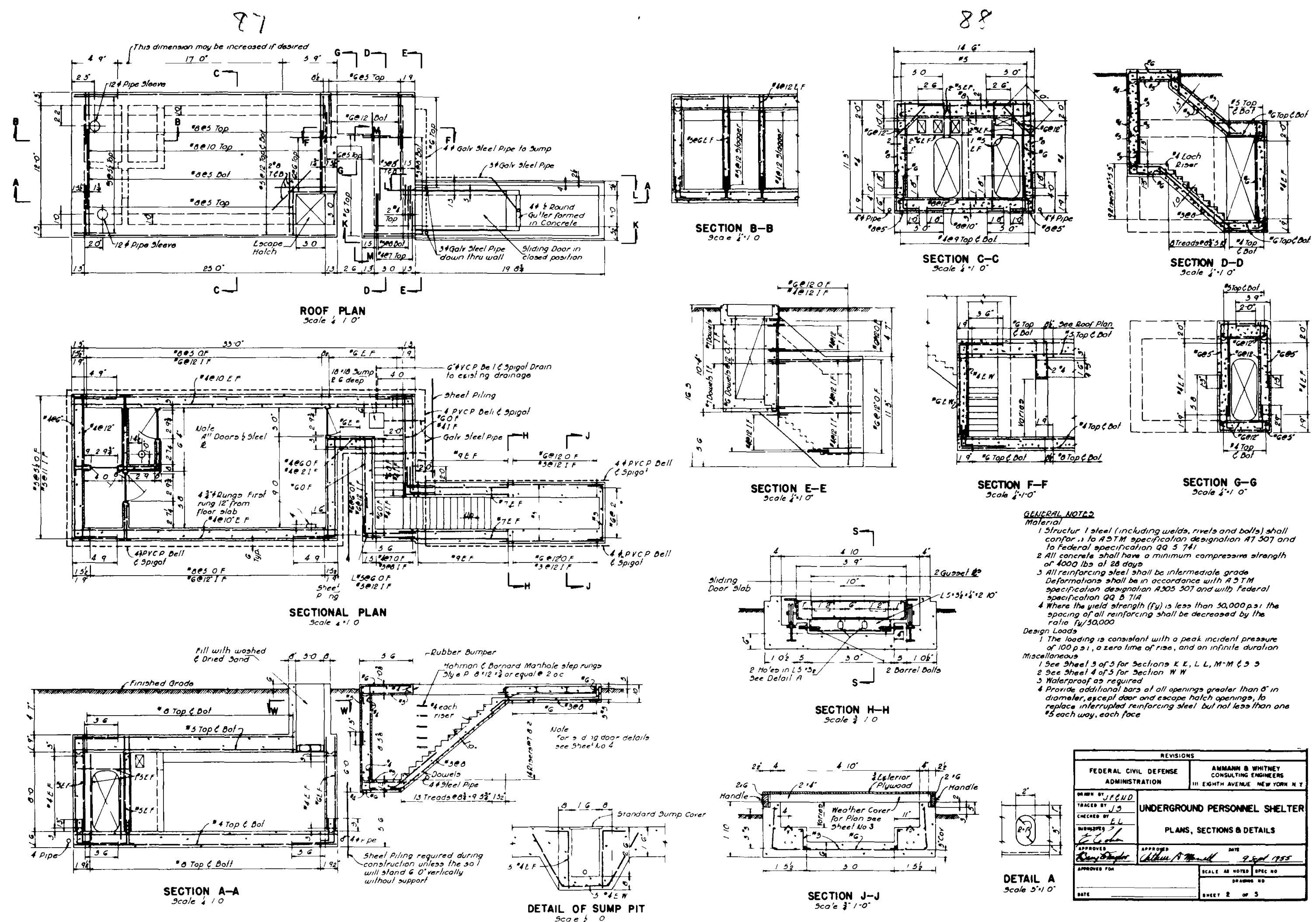

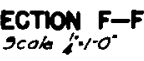

SECTION G-G

$\frac{\text { gevereq Notes }}{\text { molerial }}$

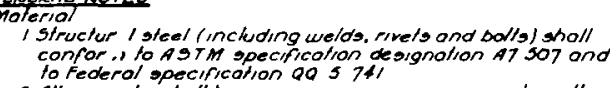

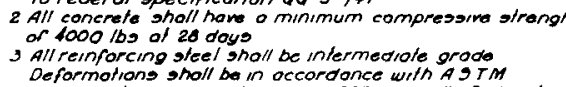

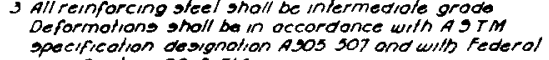

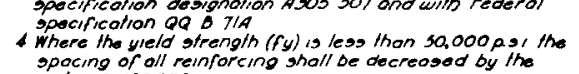

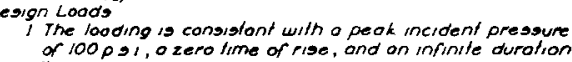

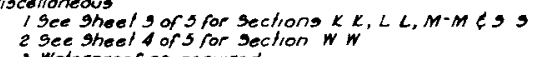

SECTION HOL

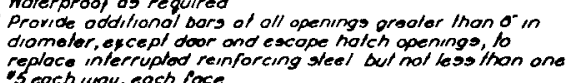
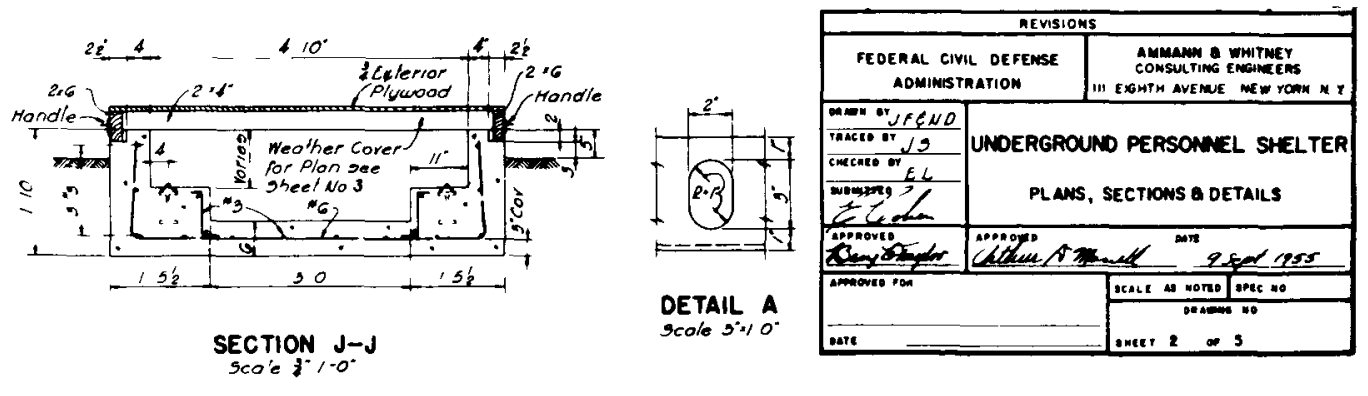

Fig. A.2-Plans, sections, and details, underground personnel shelter. 

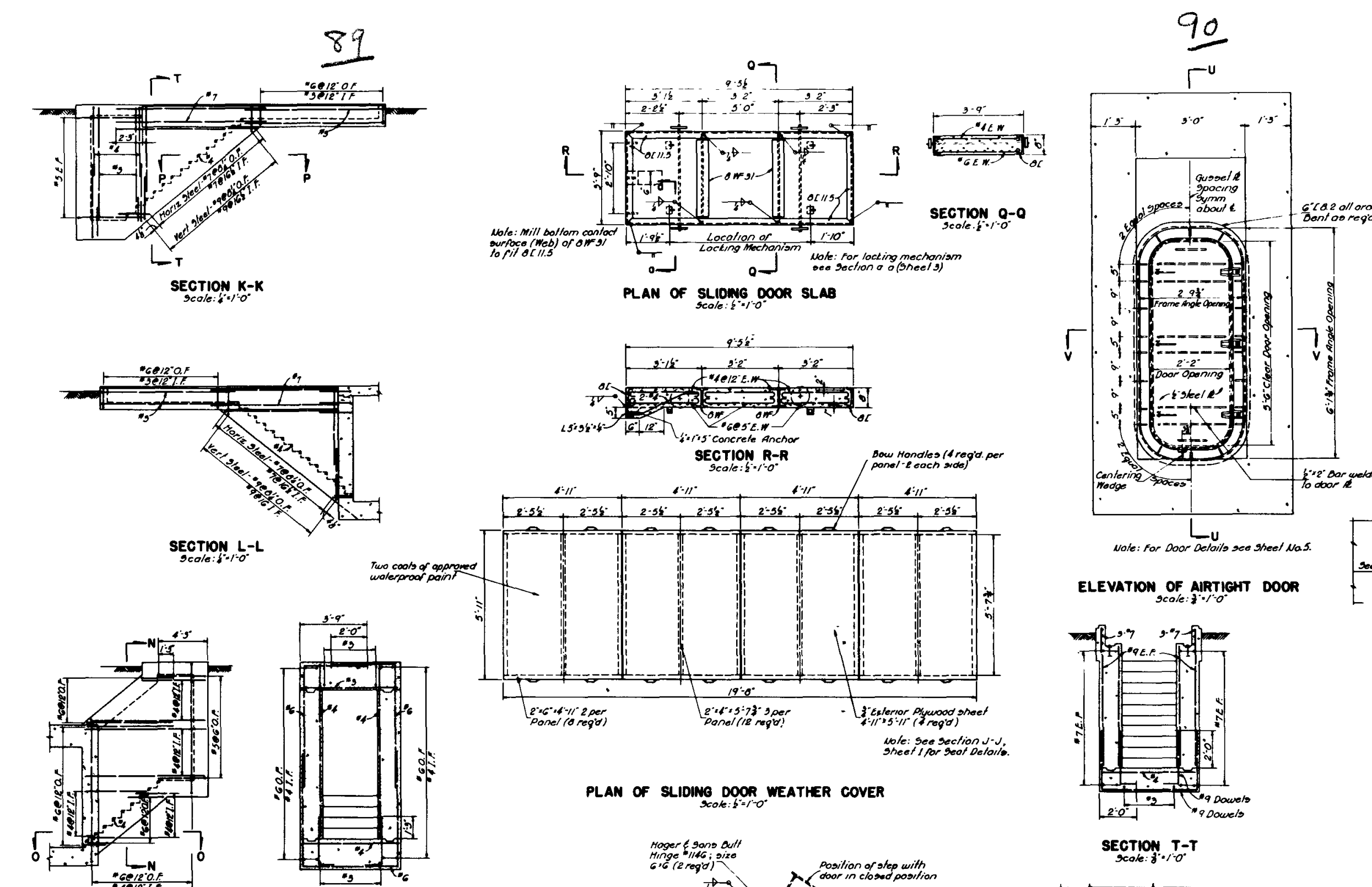

SEcTION $M-M$

SECTION N-N
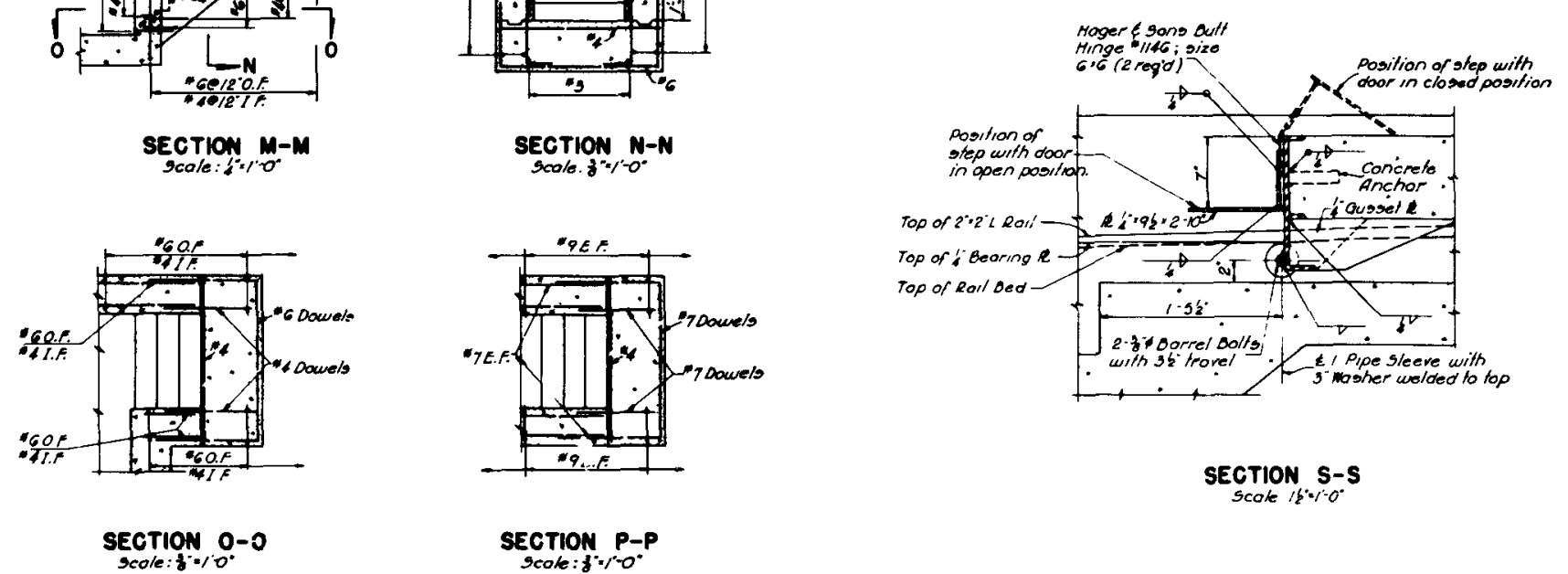

Fig. A.3-Entrance, sections, and details, underground personnel shelter.

ELEVATION OF AIRTIGHT DOOR

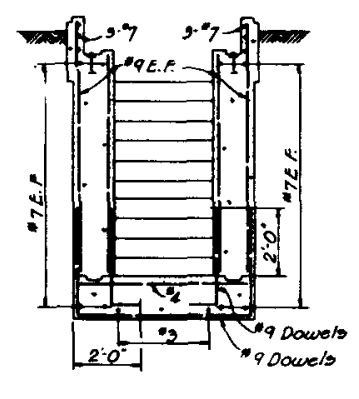

SECTION T-T T-T
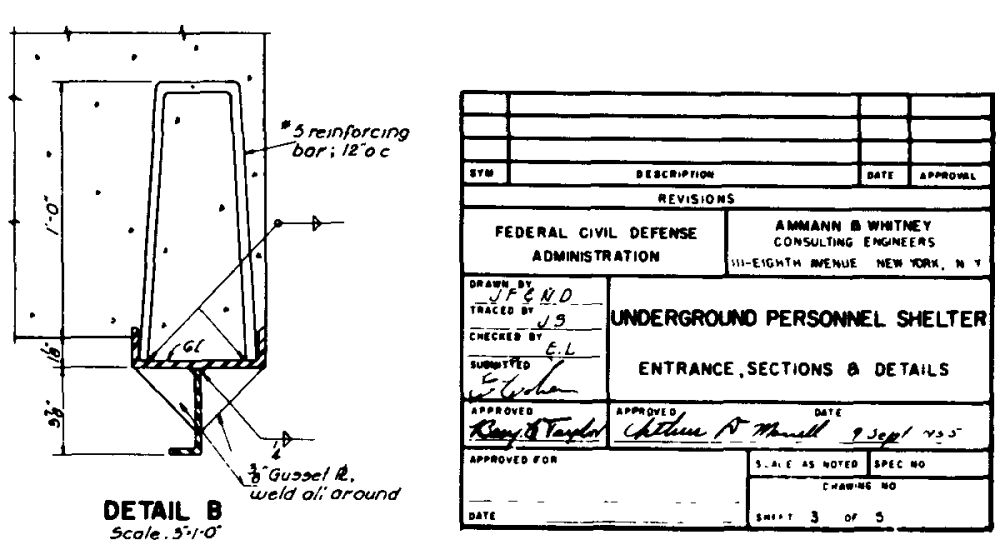


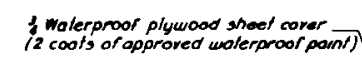
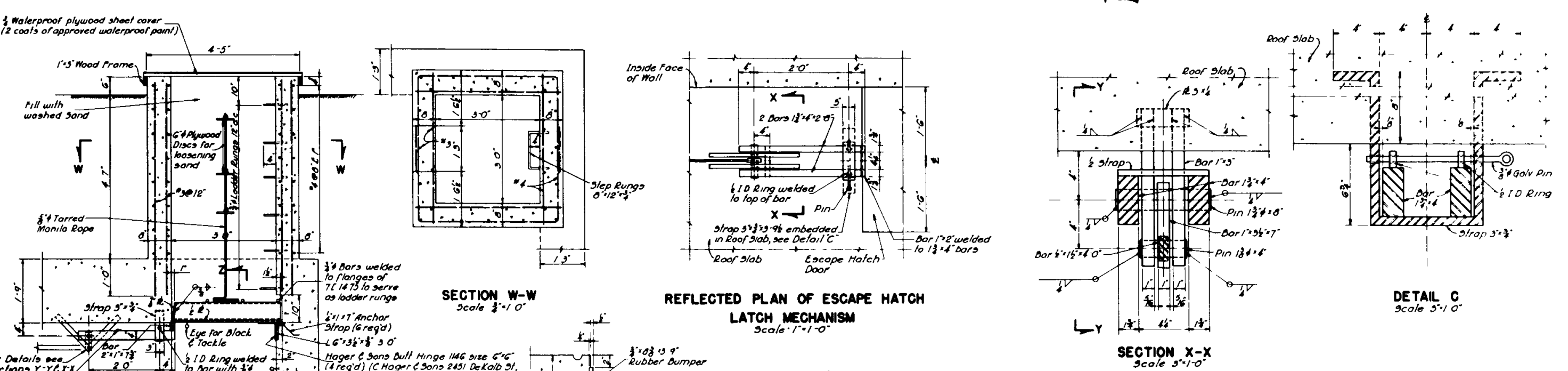

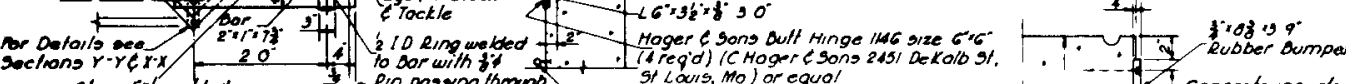

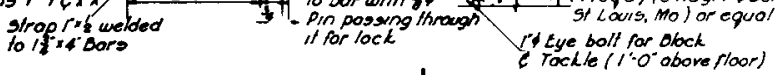

SECTION THROUGH ESCAPE HATCH

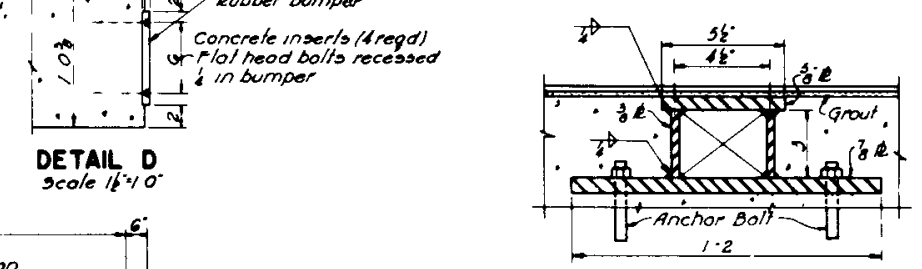

SECTION d-d

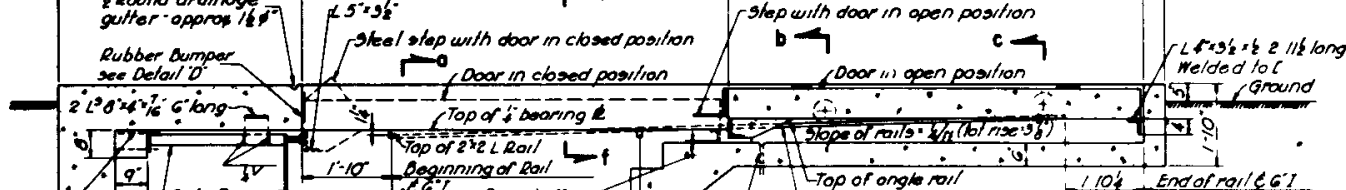

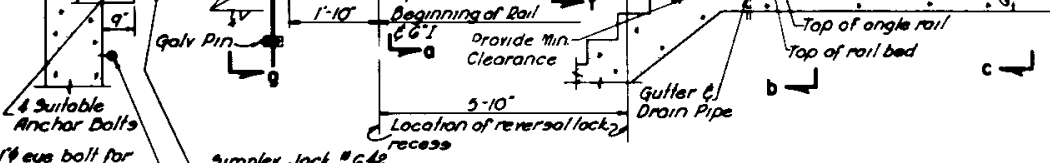

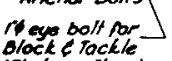

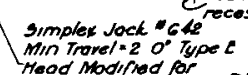

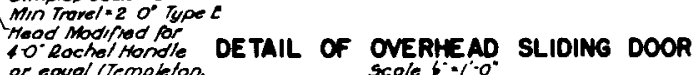

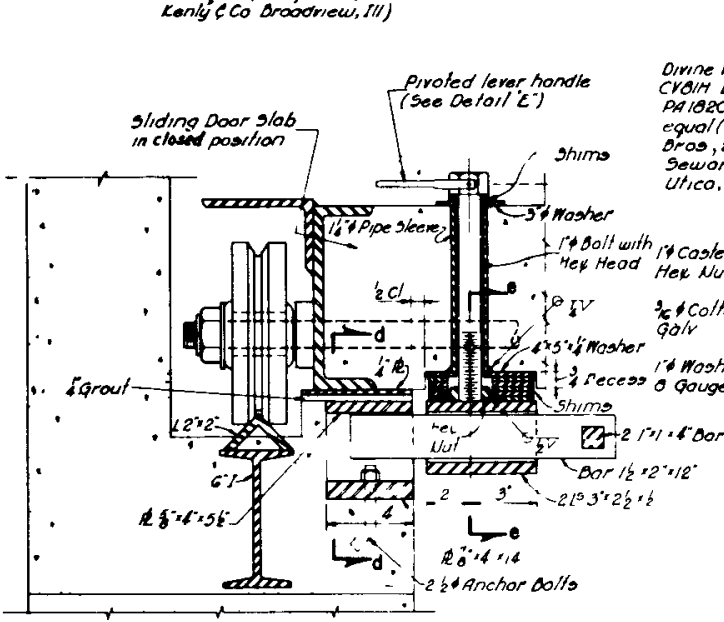

SECTION $\underset{\text { gcole } 9.0}{0.0}$

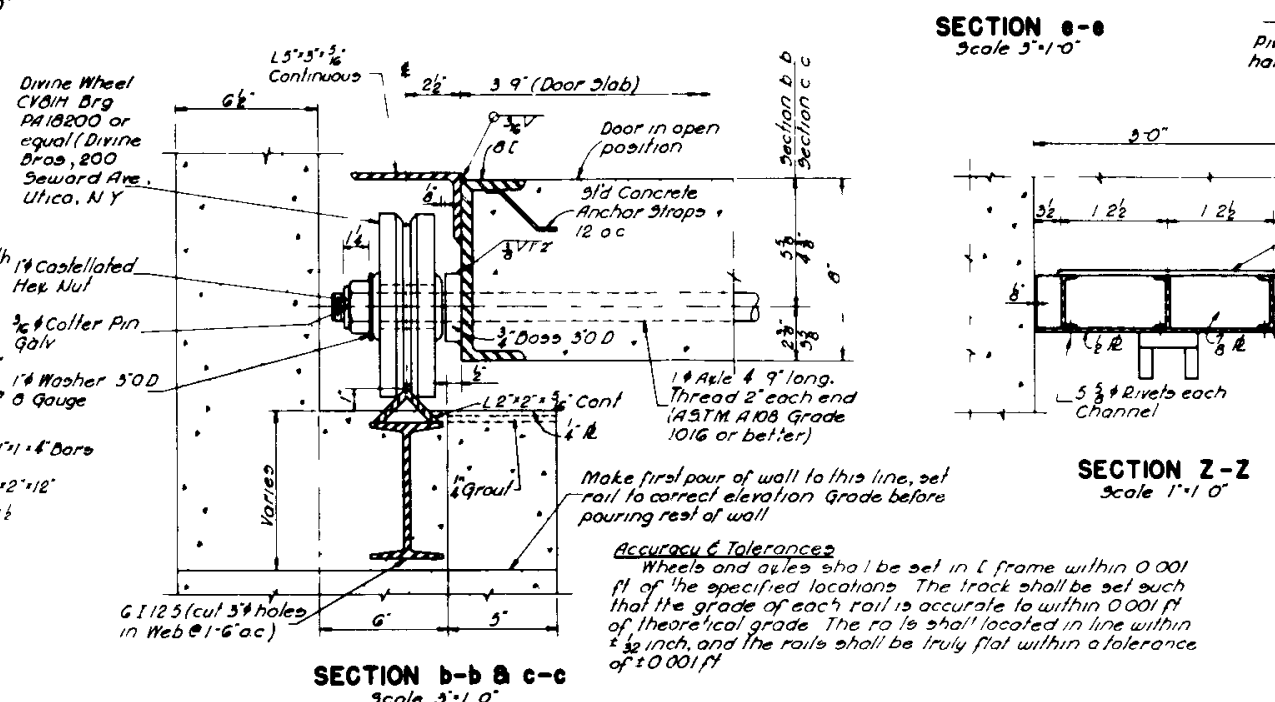

SECTION b-b a $c-c$

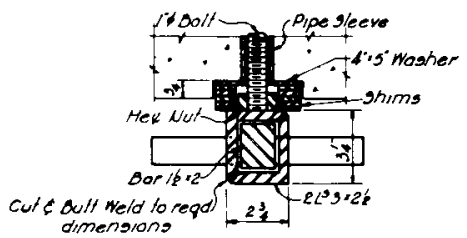

Scole $9 \cdot, 0-0$

Fig. A.4-Sliding door and escape-hatch details, underground personnel shelter.

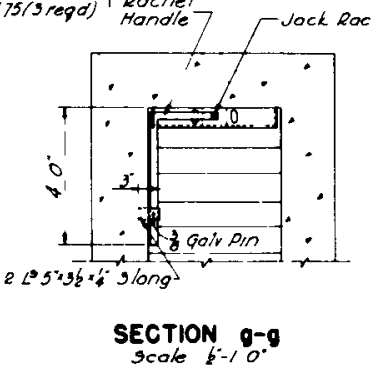

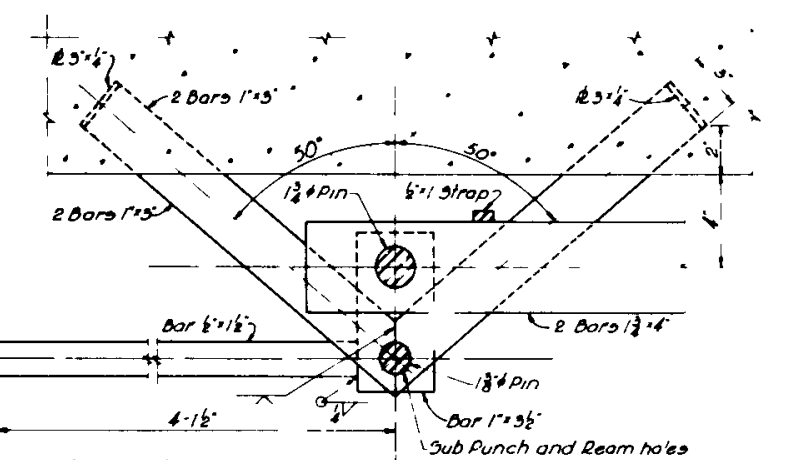

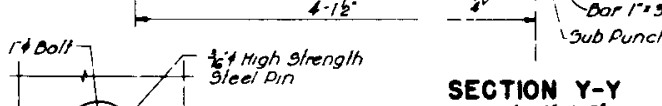

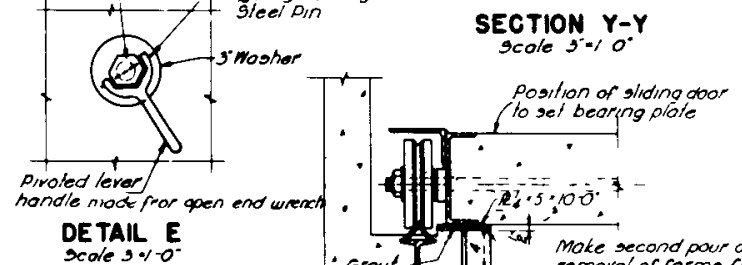

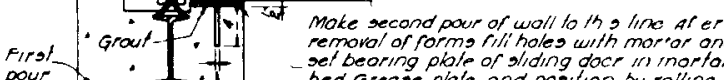

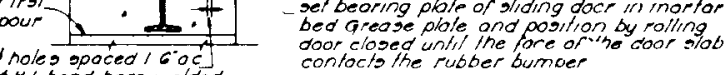

SECTION $1-4$

\begin{tabular}{|c|c|c|}
\hline \multicolumn{2}{|c|}{ 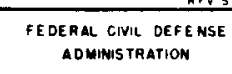 } & 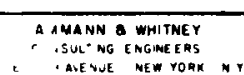 \\
\hline 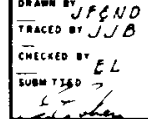 & \multicolumn{2}{|c|}{$\begin{array}{l}\text { UNOERGROUND PERSONNEL SHELTER } \\
\text { SLLDING DOOR a ESCAPE HATCH DE TALS }\end{array}$} \\
\hline 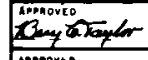 & \multicolumn{2}{|c|}{ 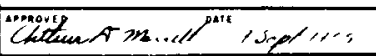 } \\
\hline & & 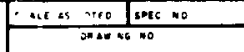 \\
\hline antrent & & \\
\hline
\end{tabular}




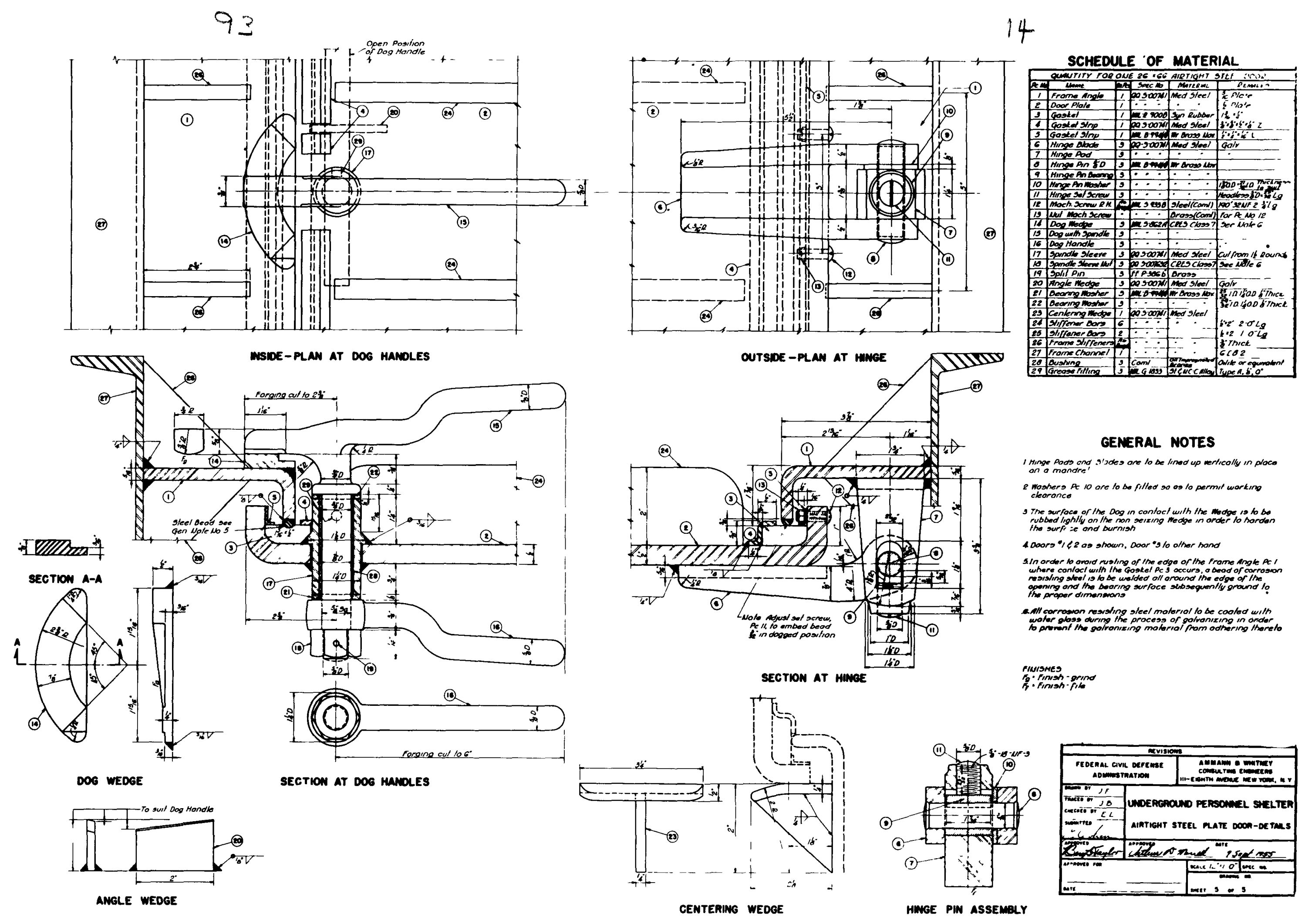

Fig. A.5 - Airtight steel-plate door details, underground personnel shelter. 



\section{A.7 SAMPLE COMPUTATIONS}

\section{A.7.1 Roof Slab Design}

Clear span: $12 \mathrm{ft} 0$ in.

Centerline span: $13 \mathrm{ft} 3$ in.

\section{Loading:}

Blast (assuming 10 per cent increase over static load) 100 psi $\times 1.10 \times 0.144=15.85$

Soil (4-ft 7-in. cover)

$0.100 \times 4.58=0.46$

Concrete (assuming a 1-ft 9 -in. thickness)

$0.150 \times 1.75=0.26$

$16.57 \mathrm{~K} / \mathrm{ft}$

Thickness

(1) Moment

$$
\begin{aligned}
\left(\mathbf{M}_{\mathbf{E}}+\mathbf{M}_{\mathrm{S}}\right)_{\mathrm{ULT}} & \stackrel{\stackrel{\mathbf{R}_{\text {max }} \mathrm{L}}{8}}{ } \\
& =\frac{16.57(12.0)^{2}(12)}{8} \\
& =3560 \mathrm{in} . \mathrm{k}
\end{aligned}
$$

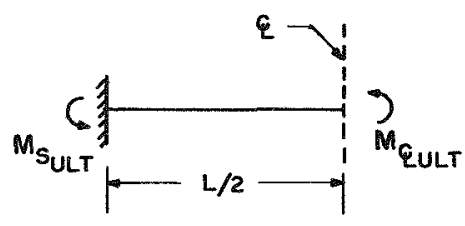

For $M_{\text {LULT }}=M_{S_{U L T}} ; p=1.5 \% ; f_{d c}^{\prime}=1.35 f_{c}^{\prime}=5400 p s i ;$ and $f_{d y}=1.35 f_{y}=67,500 p s i$

$$
\begin{aligned}
& \frac{M_{\text {LULT }}}{\mathrm{bd}^{2}} \doteq 900 \mathrm{psi} \mathrm{K} / \mathrm{in.}^{2} \text { (reference 1, page 267) } \\
& \mathrm{d}=\sqrt{\frac{1780(1000)}{12(900)}}=12.8 \mathrm{in} . \\
& \underline{\mathrm{t}(\text { req'd })=15 \mathrm{in} .}
\end{aligned}
$$

(2) Shear

$$
\begin{aligned}
& d=\frac{V}{b j v}=\frac{16.57(6)(1000)}{12(0.875)(400)}=23.6 \text { in. } \\
& t\left(\text { req }^{\prime} d\right) \doteq 26 \text { in. }
\end{aligned}
$$

From this it is seen that shear governs. Now try $12-$ by 12 -in. haunches to reduce thickness.

$$
\begin{aligned}
& d=\frac{5}{6}(23.6)=19.7 \text { in. } \\
& t(\text { req'd }) \doteq 21 \text { in. }
\end{aligned}
$$

Therefore try a 21 -in. section with 12- by 12-in. haunches. 


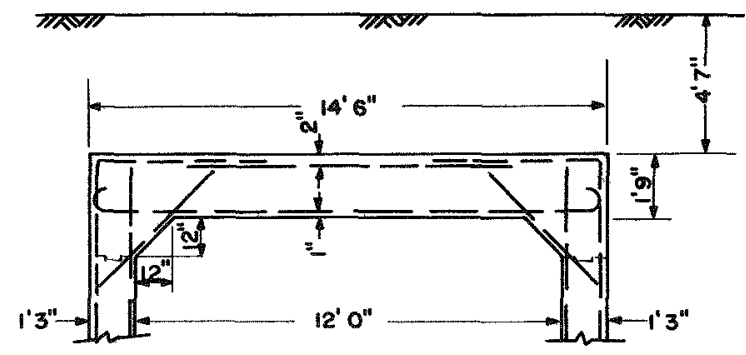

\section{Reinforcement}

For the assumed sections the moment capacity of the support is controlled by the wall steel at the construction joint below the haunch.

(1) Capacity at Support

Try \#8 at 5 in. outside face; \#6 at 12 in. inside face for wall reinforcement.

$$
\begin{aligned}
& M_{S_{U L T}}=P e=A_{S}^{\prime} f_{d y} d^{\prime}+0.85 f_{d c}^{\prime a b}(1 / 2)\left(d^{\prime}+t-a\right)-0.5 P d^{\prime} \\
& P \doteq 16.57(13.25)(1 / 2)=109.5 \mathrm{~K} \\
& a=\frac{P}{0.85 b f_{d c}^{\prime}}+\left(A_{S}-A_{\dot{s}}^{\prime}\right) \frac{f_{d y}}{0.85 b f_{d c}^{\prime}} \\
& a=\frac{109.5}{0.85(12)(4 \times 1.25)}+\frac{(1.90-0.44)(50 \times 1.25)}{0.85(12)(4 \times 1.25)}=2.15+1.79=3.94 \mathrm{in} .
\end{aligned}
$$

[The dynamic increase factor (1.25) is assumed as the average of recommended maximum values for section in flexure and section in pure compression, i.e., $(1 / 2)(0.35+0.15)=0.25$.] Therefore

$$
\begin{aligned}
& \mathrm{M}_{\mathrm{S}_{\mathrm{ULT}}}=0.44(62.5)(11.13)+0.85(5)(3.94)(6)(11.13+15.00-3.94)-0.5(109.5)(11.13) \\
& \mathrm{M}_{\mathrm{S}_{\mathrm{ULT}}}=1932 \text { in. } \mathrm{K}
\end{aligned}
$$

and

$$
\begin{aligned}
& M_{S_{U L T(1)}}=0.44(62.5)(11.13)+0.85(5)(3.04)(6)(26.13-3.04)-0.5(64)(11.13) \\
& { }^{M_{U L T(1)}}=1741 \text { in. } \mathrm{K} \\
& R_{1}=\frac{1741}{13.25}=130 \mathrm{~K} \doteq 128 \mathrm{~K}
\end{aligned}
$$

(2) Resistance $\mathbf{R}_{\max }$ at $€$ Yielding

E yield moment $M_{\mathbf{E}_{U L T}}=A_{s} f_{d y}(d-0.5 a)$

$$
\begin{aligned}
& A_{s}=\# 8 \text { at } 5 \text { in., } 1-\text { in. cover } \\
& a=\frac{A_{S} f_{d y}}{0.85 b f_{d c}^{\prime}}=\frac{1.90(67.5)}{0.85(12)(5.4)}=2.33 \text { in. }
\end{aligned}
$$




$$
\begin{aligned}
& M_{\mathbb{E}_{\mathrm{ULT}}}=1.90(67.5)(19.50-1.16)=2360 \text { in. } \mathrm{K} \\
& \mathrm{M}_{\mathrm{S}_{\mathrm{ULT}}}=1912 \text { in. } \mathrm{K} \quad \text { (by trial using Eq. A.2) }
\end{aligned}
$$

Therefore

$$
R_{\max }=\frac{8}{13.25(12)}(2360+1912)=215 \mathrm{~K}
$$

(3) Stiffness

It is sufficiently accurate for stiffness computations in this case to neglect the effect of the haunches. The resistance function for the roof slab is shown in Sec. A.7.2.

$$
\begin{aligned}
\mathrm{X}_{\mathrm{yp}_{1}} & =\frac{\mathrm{R}_{1} \mathrm{~L}^{3}}{384 \mathrm{EI}}+\frac{\mathrm{kL}(1+\mu) \mathrm{R}_{1}}{4 \mathrm{AE}} \\
& =130\left[\frac{13.25^{3}}{384\left(432 \times 10^{3}\right)\left(\frac{1}{12}\right)(1.75)^{3}}+\frac{1.2(13.25)(1.1)}{4(1.75)\left(432 \times 10^{3}\right)}\right] \\
& =130(0.0315+0.0057) 10^{-3}=\underline{0.00483} \mathrm{ft} \\
\mathrm{X}_{\mathrm{yp}_{2}} & =\frac{5\left(\mathrm{R}_{\max }-\mathrm{R}_{1}\right) \mathrm{L}^{3}}{384 \mathrm{EI}}+\frac{\mathrm{kL}(1+\mu)\left(R_{\max }-R_{1}\right)}{4 \mathrm{~A}_{\mathrm{s}}}+\mathrm{X}_{\mathrm{yp}_{1}} \\
& =(215-130)(0.1575+0.0057) 10^{-3}+0.00483=0.01873 \mathrm{ft}
\end{aligned}
$$

(4) Capacity at $\mathrm{E}$

$$
\begin{aligned}
& M_{\mathbb{E}_{\mathrm{ULT}}}=\frac{R_{U L T} \cdot L}{8}-M_{S_{U L T}}=\frac{219(13.25)(12)}{8}-1932=\underline{2408} \text { in. } K \\
& A_{S}(r e q ' d)=\frac{M_{E_{U L T}}}{f_{d y}(d-0.5 a)} \\
& a=\frac{A_{s} f_{d y}}{0.85 f_{d c}^{\prime} b}=1.225 A_{S} \\
& A_{S}(r e q ' d)=\frac{2408}{(1.35 \times 50)\left(19.50-0.612 A_{g}\right)}=1.95 \mathrm{sq} \mathrm{in.}
\end{aligned}
$$

Therefore try \#8 at 5 in.
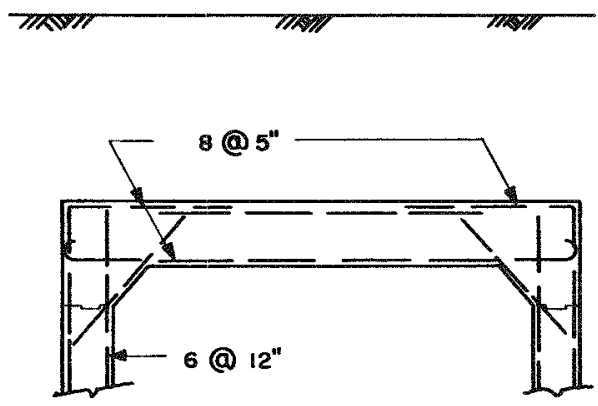
A.7.2 Resistance Function

Resistance $R_{1}$ at Support Yielding

$$
R_{1}=\frac{12 M_{\text {SULT(1) }}}{L}=\frac{M_{\text {SULT(1) }} \text { (in. K) }}{13.25}
$$

$M_{S_{U L T(1)}}$ is obtained using Eq. A.2, and, since the value of $(1 / 2) R_{1}=P$ is necessary to solve this equation, the solution is obtained by converging trials. The final trial is shown below.

From preceding trial $R_{1}=128 \mathrm{~K}$, therefore $P=64 \mathrm{~K}$. Using Eq. A.3

$$
\mathrm{a}=\frac{64}{51}+1.79=3.04 \mathrm{in} \text {. }
$$

Therefore elastic range stiffness

$$
\mathrm{k}_{1}=\frac{\mathrm{R}_{1}}{\mathrm{X}_{\mathrm{yp}_{1}}}=\underline{26900} \mathrm{~K} / \mathrm{ft}
$$

and elasto-plastic range stiffness

$$
\mathrm{k}_{2}=\frac{\mathrm{R}_{\mathrm{max}}-\mathrm{R}_{1}}{\mathrm{X}_{\mathrm{yp}_{2}}-\mathrm{X}_{\mathrm{yp}_{1}}}=6110 \mathrm{~K} / \mathrm{ft}
$$

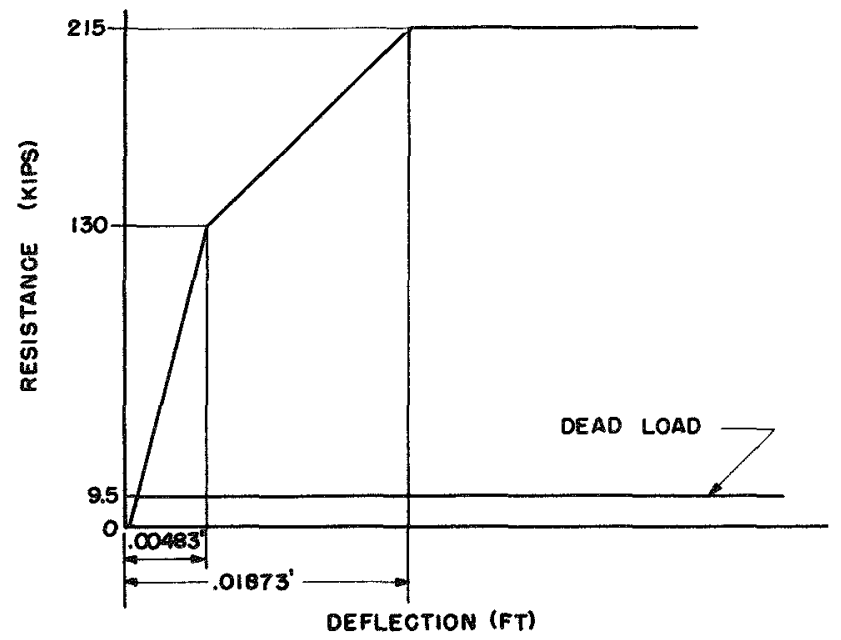

Equivalent Masses for Analysis

$$
\mathrm{m}=\frac{\text { D.L. }}{32.2}=\frac{9.53}{32.2}=0.296 \mathrm{kip}-\mathrm{sec}^{2} / \mathrm{ft}
$$

$$
\begin{array}{ll}
\text { Elastic } & \mathrm{m}_{1}=0.766(0.296)=0.227 \\
\text { Elasto-plastic } & \mathrm{m}_{2}=0.790(0.296)=0.234 \\
\text { Plastic } & \mathrm{m}_{3}=0.667(0.296)=0.197
\end{array}
$$


Numerical-integration Solution for Deflection

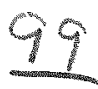

\begin{tabular}{|c|c|c|c|c|c|c|c|c|c|c|c|}
\hline $\begin{array}{c}\text { t, } \\
\text { sec }\end{array}$ & $\begin{array}{l}\bar{F} \\
\text { kip }\end{array}$ & $\begin{array}{r}\overline{\mathbf{R}}, \\
\text { kip }\end{array}$ & $\overline{\mathbf{F}}-\overline{\mathbf{R}}$ & $\frac{\Delta t}{m_{e}}$ & $\Delta \dot{x}$ & $\dot{\mathbf{x}}$ & $\dot{\mathbf{x}}$ & $\Delta x$ & $\mathrm{x}$ & $\begin{array}{c}\mathbf{R} \\
\text { (calc.) }\end{array}$ & $\begin{array}{c}R \\
\text { (calc.) }\end{array}$ \\
\hline 0 & \multirow{4}{*}{191} & & & & & 0 & & & 0 & 0 & \multirow{3}{*}{5.5} \\
\hline \multirow{3}{*}{0.001} & & 5 & 186 & 0.0044 & 0.82 & & 0.41 & 0.00041 & & & \\
\hline & & & & & & 0.82 & & & 0.00041 & 11 & \\
\hline & & 27 & 164 & 0.0044 & 0.72 & & 1.18 & 0.00118 & & & 27 \\
\hline 0.002 & & 68 & 123 & 0.0044 & 0.54 & 1.54 & 1.81 & 0.00181 & 0.00159 & 43 & \multirow{2}{*}{67} \\
\hline \multirow[t]{2}{*}{0.003} & & & & & & 2.08 & & & 0.00340 & 91 & \\
\hline & & 110 & 81 & 0.0044 & 0.36 & & 2.26 & 0.00226 & & & \multirow[t]{2}{*}{109} \\
\hline \multirow[t]{2}{*}{0.004} & & & & & & 2.44 & & & 0.00566 & 128 & \\
\hline & & 135 & 56 & 0.0043 & 0.24 & & 2.56 & 0.00256 & & & \multirow[t]{2}{*}{136} \\
\hline \multirow[t]{2}{*}{0.005} & & & & & & 2.68 & & & 0.00822 & 144 & \\
\hline & & 153 & 38 & 0.0043 & 0.17 & & 2.76 & 0.00276 & & & \multirow[t]{2}{*}{153} \\
\hline \multirow[t]{2}{*}{0.006} & & & & & & 2.85 & & & 0.01098 & 161 & \\
\hline & & 170 & 21 & 0.0043 & 0.09 & & 2.90 & 0.00290 & & & \multirow[t]{2}{*}{170} \\
\hline 0.007 & & 188 & 3 & 0.0043 & 0.01 & 2.94 & 2.95 & 0.00295 & 0.01388 & 178 & \\
\hline \multirow[t]{2}{*}{0.008} & & & & & & 2.95 & & . & 0.01683 & 196 & 187 \\
\hline & & 201 & -10 & 0.0043 & -0.04 & & 2.93 & 0.00293 & & & \multirow{9}{*}{201} \\
\hline 0.009 & & 205.5 & -14.5 & 0.0051 & -0.07 & 2.91 & 2.87 & 0,00287 & 0.01976 & 205.5 & \\
\hline \multirow{2}{*}{0.010} & & 200.0 & 170 & & -0.08 & 2.84 & 2.08 & . & 0.0226 & & \\
\hline & & & & 0.0508 & -0.74 & 24 & 2.47 & 0.0247 & & & \\
\hline 0.020 & & & & 0.0508 & -0.74 & 0.00 & 1.73 & 0.0173 & 然 & & \\
\hline 0.030 & & & & & & 1.36 & & & 0.0646 & & \\
\hline \multirow{2}{*}{0.040} & & & & 0.0000 & -0.14 & 0.62 & 0.99 & 0.0099 & 0.0745 & & \\
\hline & $r$ & 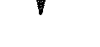 & 1 & 0.0508 & -0.74 & & 0.25 & 0.0025 & 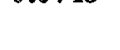 & & \\
\hline 0.050 & & & & & & -0.12 & & & $\underline{0.0770}$ & $\Longrightarrow$ & \\
\hline
\end{tabular}

Therefore use assumea section for final.

Note: $\overline{\mathrm{F}}=$ force, $\overline{\mathrm{R}}=$ resistance, $\Delta \dot{\mathrm{X}}=$ acceleration, $\dot{\mathrm{X}}=$ velocity, $\mathrm{X}=$ displacement.

\section{REFERENCES}

1. Charles S. Whitney, Plastic Theory of Reinforced Concrete Design, Trans. Am. Soc. Civil Engrs., 107: 251-282 (1942).

2. C. S. Whitney, B. G. Anderson, and E. Cohen, Design of Blast Resistant Construction for Atomic Explosions, J. Am. Concrete Inst., 26: 679 (March 1955).

3. C. S. Whitney, B. G. Anderson, and E. Cohen, Design of Blast Resistant Construction for Atomic Explosions, J. Am. Concrete Inst., 26: 634 (March 1955).

4. C. S. Whitney, B. G. Anderson, and E. Cohen, Design of Blast Resistant Construction for Atomic Explosions, J. Am. Concrete Inst., 26: 612 (March 1955).

5. C. S. Whitney, B. G. Anderson, and E. Cohen, Design of Blast Resistant Construction for Atomic Explosions, J. Am. Concrete Inst., 26: 615 (March 1955). 


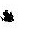


100

APPENDTX B

\section{PROTECTIVE VENTILATION}

By

Frank G. Ort

and

Ralph V. Schumacher

U. S. Army Chemical Center 


\section{1}

\section{APPENDIX B}

\section{PROTECTIVE VENTILATION}

\section{B.1 INTRODUCTION}

\section{B.1.1 Objective}

The purpose of this work was to provide protection against atomic, bacteriological, and chemical attack for two prototype 50-man FCDA shelters and to determine the ability of the protective installations to withstand an atomic detonation.

\section{B.1.2 Background}

For a number of years the Chemical Corps has been active in the development of equipment and methods of operation for protective shelters. There are two general methods by which the occupants of a shelter can be provided with protection against all toxic gases and aerosols other than through the use of individual protective equipment such as the gas mask.

The first method involves the use of a motor blower with filter units to provide a continuous supply of filtered air which maintains a positive pressure of purified air within the structure and acts to preclude the entrance of atmospheric contaminants from without. The $\mathbf{E}_{4}$ antiblast closure was developed for protection of the filter units and personnel within this type of shelter during the extreme overpressures encountered during an atomic detonation. The development and tests conducted using this equipment on a pressurized type of shelter and under conditions of a nuclear explosion are reported in Greenhouse Annex 6.10, WT-42, a classified report.

The second method of providing the desired shelter protection is through the use of a new filter medium known as "diffusion board." This board is similar to ordinary wall boards, such as Celotex, except that activated charcoal is added to the wet pulp make-up. This board, when used to form the walls of a protective enclosure, acts as a reactive diffusion barrier. Carbon dioxide and water vapor concentrations which would normally increase continually within an enclosure under conditions of prolonged human occupancy increase only to moderate levels and stabilize due to the process of diffusion through the board. The driving force for the diffusion process is the concentration gradient across the barrier. By the same token, an appreciable concentration of toxic gas outside the enclosure would set up a reverse driving force into the enclosure; however, in passage through the board, the toxic agent is removed by the activated charcoal incorporated directly within the board. The protection afforded by a shelter of this type is dependent upon very good seals at all joints and the elimination of all sources of air leakage from without.

The FCDA requested that the Chemical Corps participate in their shelter program being conducted on Operation Teapot at the Nevada Test Site (NTS) in the spring of 1955. Two 50-man shelters designed by Ammann \& Whitney were made available for Chemical Corps instrumentation. Each of the shelters was tested in a different test detonation, although the overpressure anticipated at each test shelter was approximately 100 psi. 


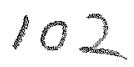

Since the first of these shelters was tested in the early shot, it was decided to equip this test shelter as a diffusion-board type of protective shelter. The second shelter was involved in the open shot. This shelter was equipped with a motor blower, filter, and pertinent equipment required for operation as a pressurized type protective shelter. Aerosol tests were conducted before and after the shot on each of these shelters to determine in each case if there was any loss in protective efficiency of the shelter as a result of the test detonation.

\section{B.1.3 Preshot Development Work (Diffusion Shelter)}

(a) General. The interior of the shelter proper was a room approximately $25 \mathrm{ft}$ long, $12 \mathrm{ft}$ wide, and $8 \mathrm{ft}$ high (see Chap. 1). The entrance door was a Navy type steel bulkhead door equipped with rubber gaskets and a series of levers and dogs for securing a tight air seal. In the roof in the right rear corner of the structure was the emergency escape hatch, $3 \mathrm{by} 3 \mathrm{ft}$, equipped with a steel door and earth-filled to a depth of $6 \mathrm{ft} 6 \mathrm{in}$. It was felt that this dirt cover would be sufficient to preclude the entrance of contaminants through the escape hatch and that the rubber-gasketed steel bulkhead door should provide an airtight seal when the door was clamped into position.

The diffusion-board installation was made on a wood framing of nominal 2- by 4-in. lumber attached to the masonry walls. A special type of construction was used to set the wood framing away from the walls and ceiling to provide a continuous and interconnected void area between the diffusion board and the masonry walls. The void width around the walls varied from $1 \%$ to $3 \%$ in. except at the closets, which will be subsequently described, and at the ceiling, where the thickness of the void area was approximately $1 \mathrm{ft}$. The construction of the wood framing was arranged with sufficient clearance around both the escape hatch and entrance door to permit ready access to each of these doors.

Mechanical ventilation of the void area was provided since, during normal shelter occupancy without ventilation of the void, the carbon dioxide and water vapor diffusing through the diffusion-board wall would reach an equilibrium with the concentration on the protected side of the barrier, neutralizing the driving force for diffusion.

The air inlet to the void area consisted of a length of standard 6-in. steel pipe equipped at the top with a pipe tee (whose open ends were covered with expanded metal), which was installed about 3 it above the level of the dirt fill on top of the shelter. The lower end of the pipe was interconnected to an $\mathrm{E}_{4}$ antiblast closure, thence to the inlet of a Buffalo Forge motor blower, model No. SKH33HD32. An orifice was installed between the pipe flanges, together with upstream and downstream taps for flow measurement. This equipment is shown in Fig. B.1.

The output side of the blower was connected to a flanged sheet-metal box which contained an adjustable plate for varying the blower exhaust opening and which was used as a method of controlling the output rate of air flow. Surmounting this plate were two 10- by 10-in. Dustop type air filters set in series and a cover plate of expanded metal which was held in place by a series of $1 / 4$-in. machine screws located around the outer perimeter. The air inlet equipment was housed in a closet covered with $5 / 8$-in. plywood around the air inlet equipment. Approximate floor dimensions of the closet as shown in Fig. B. 2 were $2 \frac{1}{4}$ by $9 \frac{1}{2} \mathrm{ft}$.

The air exhaust equipment, which is shown in Fig. B.3, consisted of a base of channel iron upon which an $\mathrm{E}_{4}$ antiblast closure was installed. The top of the antiblast closure was connected to a section of 6-in. pipe running about $3 \mathrm{ft}$ above the dirt fill and surmounted by a pipe tee.

The closet for this equipment was covered with plywood and occupied a floor space 2 by 2 ft. This is shown in Fig. B.4. The open ends of the pipe tees at the inlet and exhaust were oriented to a position $90^{\circ}$ from $\mathrm{GZ}$. The pipes were further strengthened by the addition of a 2 -ft deep 3 - by 3 -ft concrete block cast around the pipes to provide additional strength where these pipes extend through the roof of the shelter. Further details of construction are shown in Figs. B.5 through B.8.

(b) Pressure Tests of Diffusion Board. Since the diffusion board represents a very recent development, there were no available test data on what pressure the board would withstand without rupture. A series of static pressure tests was arranged, using a wood frame having a 
103

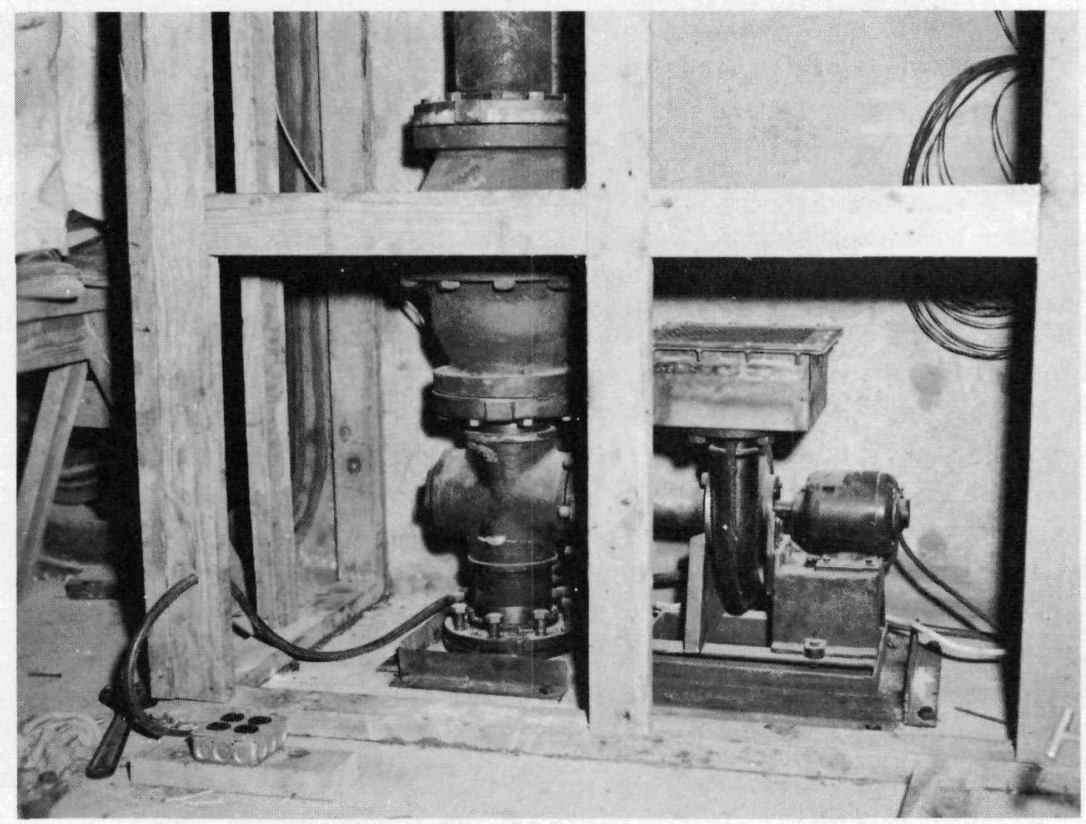

Fig. B.1-Air inlet equipment installation.

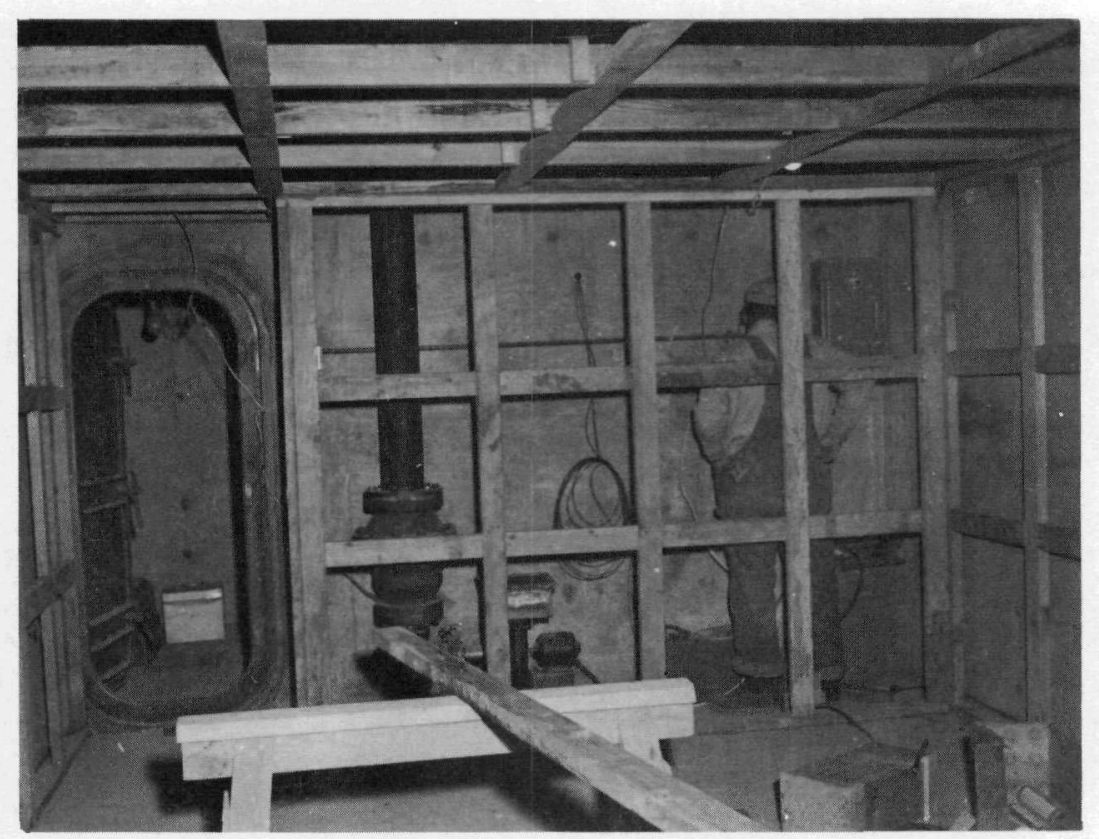

Fig. B.2-Front wall framing construction, showing closet. 


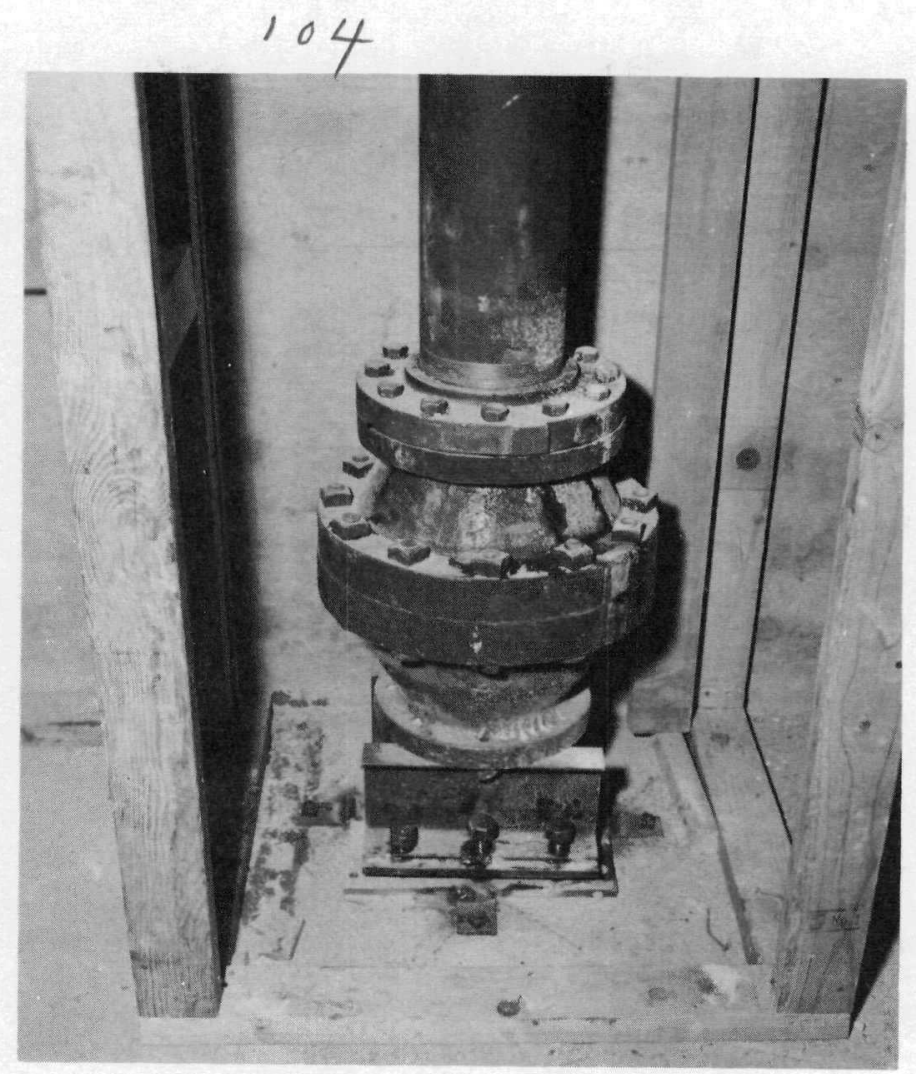

Fig. B.3-Air exhaust antiblast closure installation.

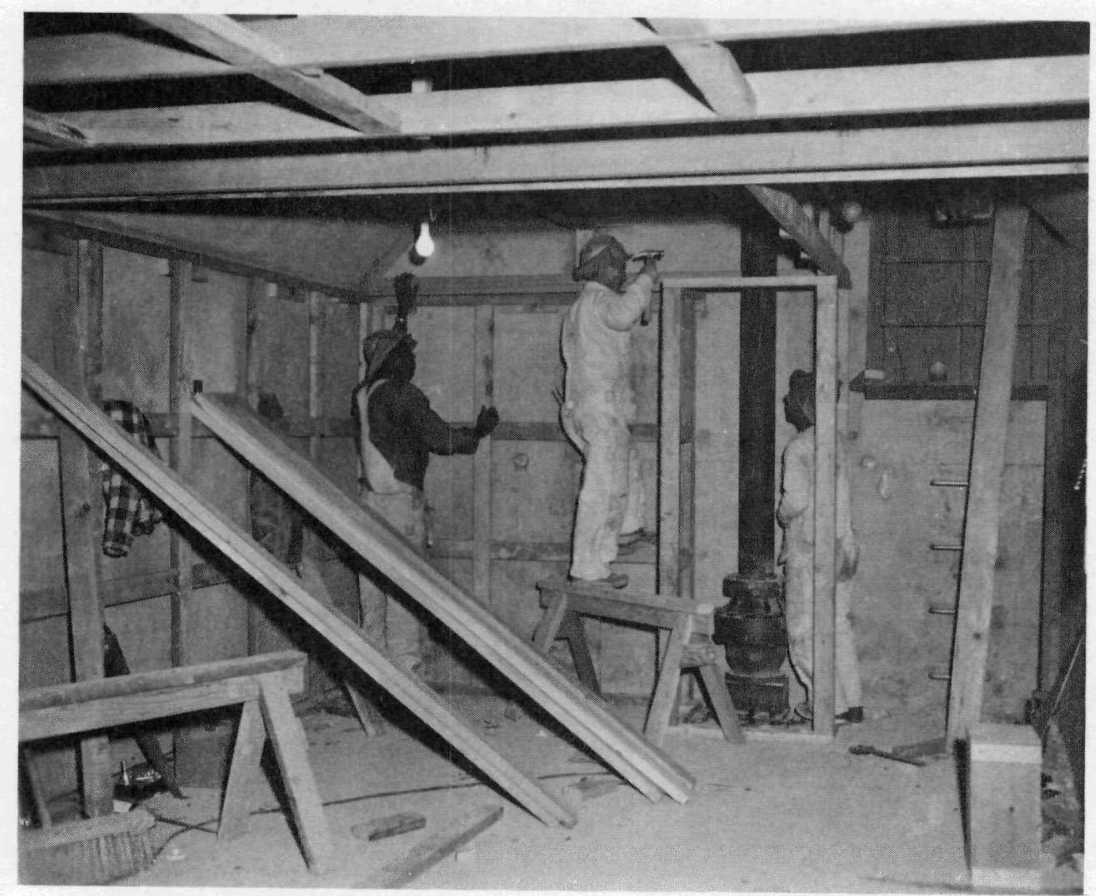

Fig. B.4-Air exhaust equipment and closet. 


\section{5}

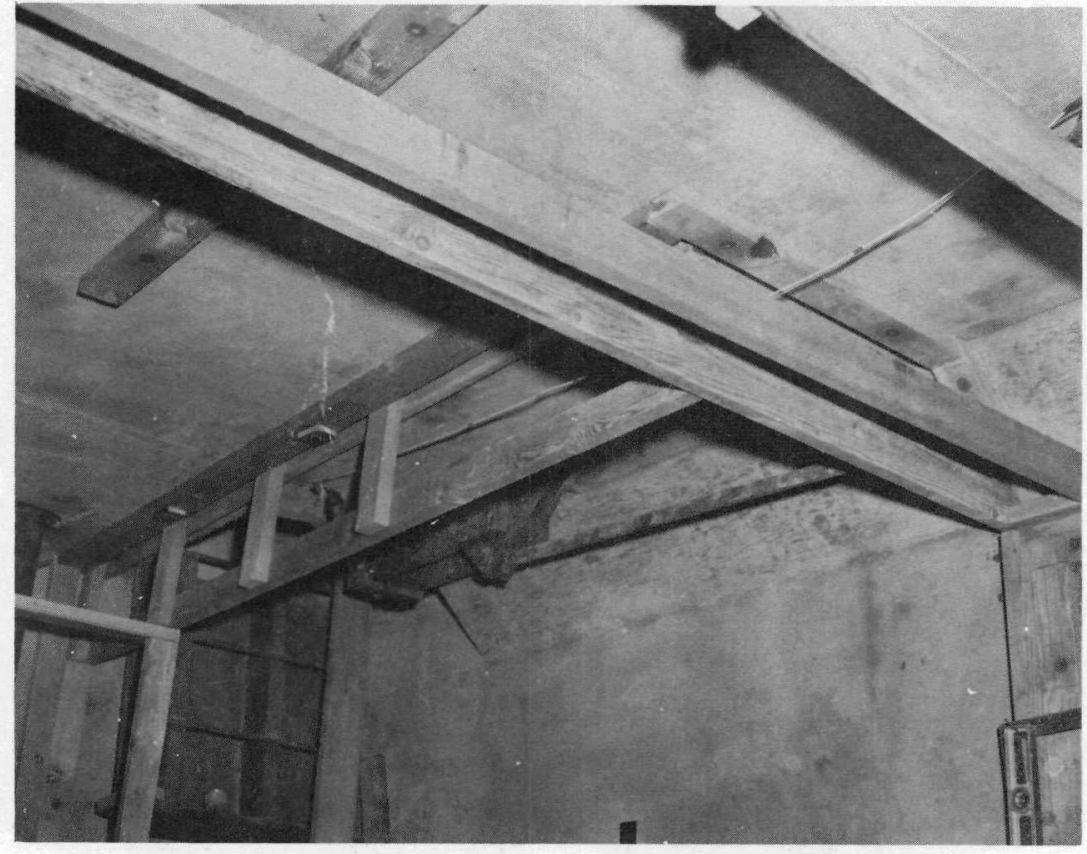

Fig. B.5 - Incomplete construction around escape hateh.

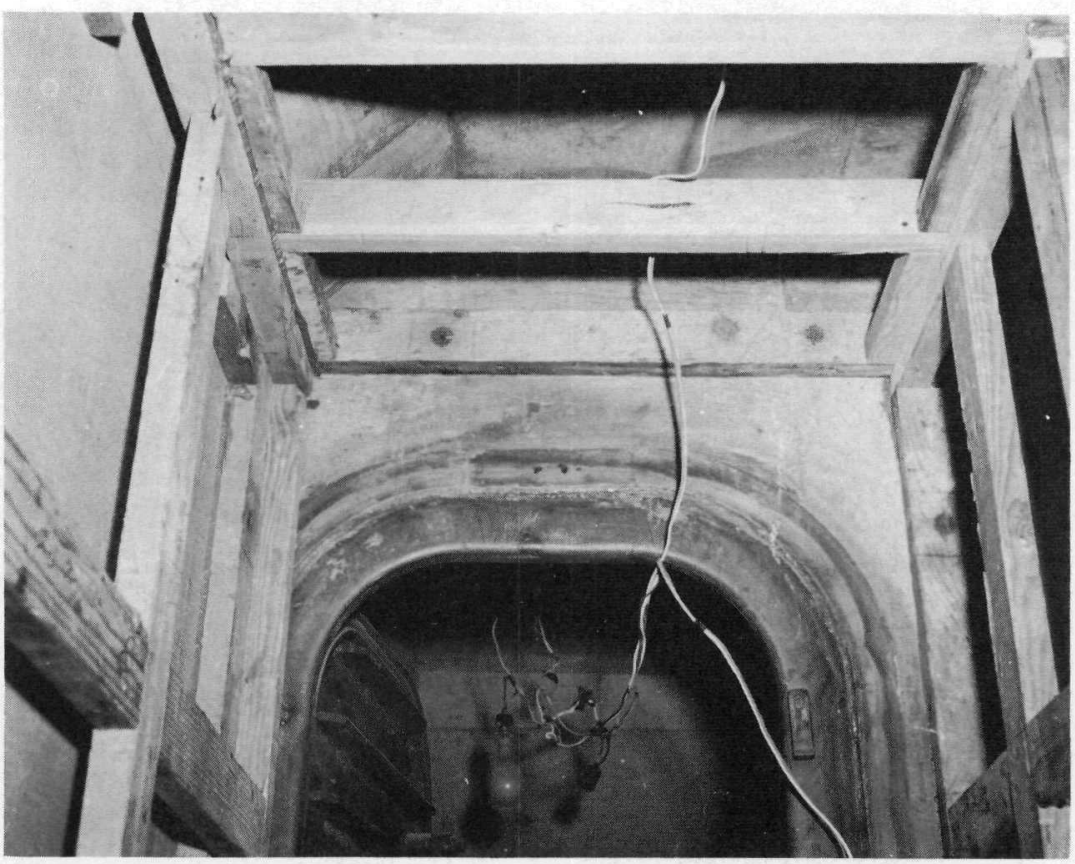

Fig. B.6-Incomplete construction around entrance door. 


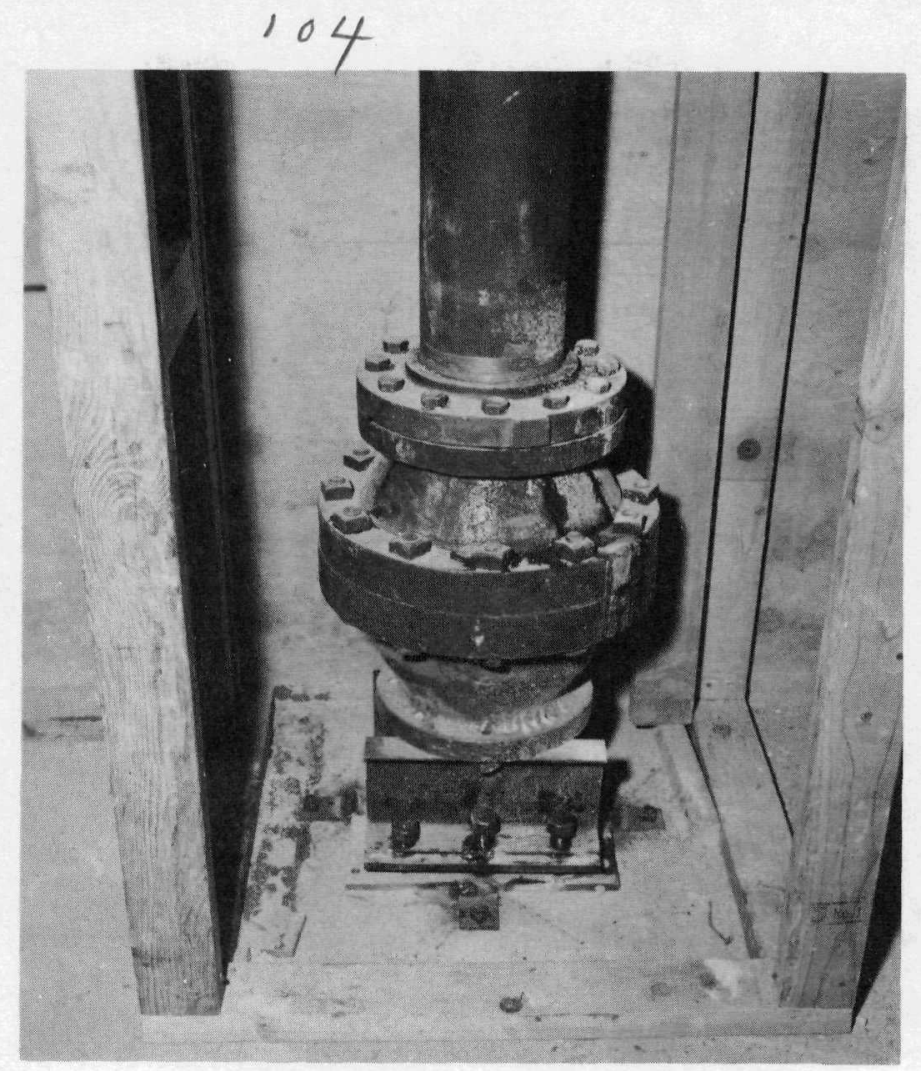

Fig. B.3-Air exhaust antiblast closure installation.

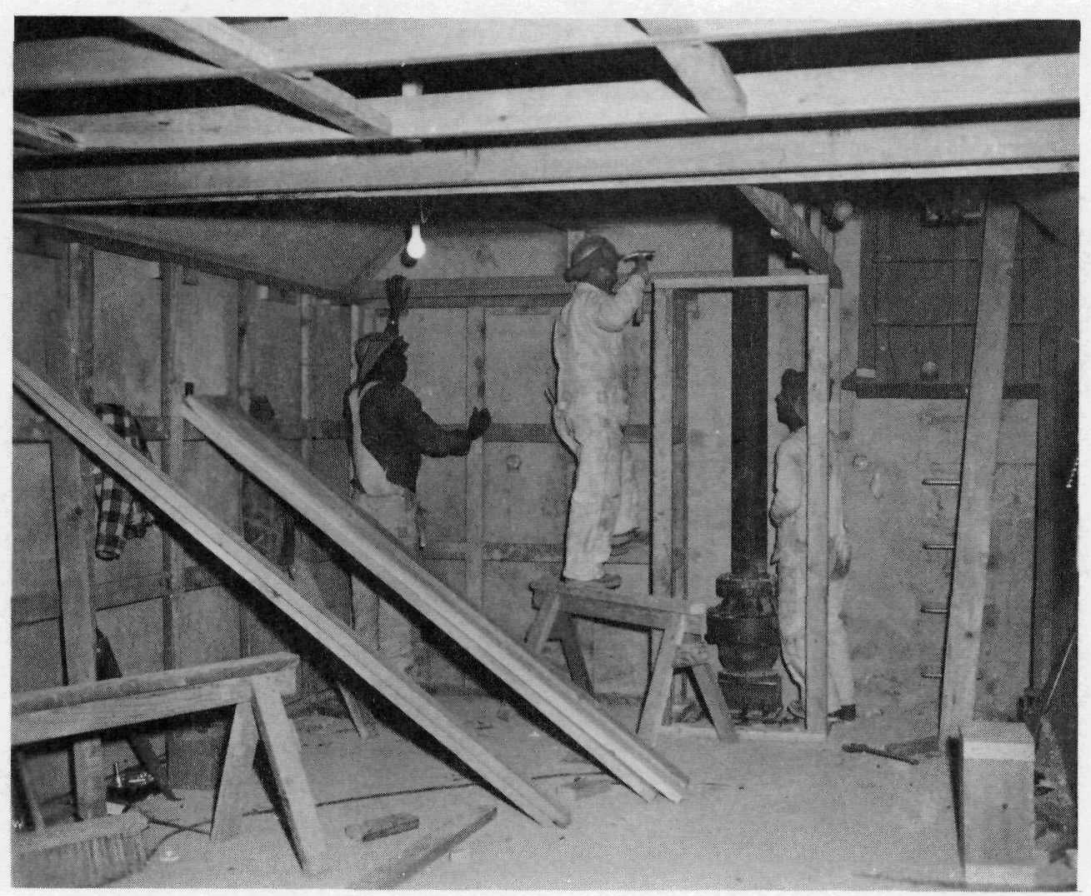

Fig. B.4-Air exhaust equipment and closet. 


\section{6}

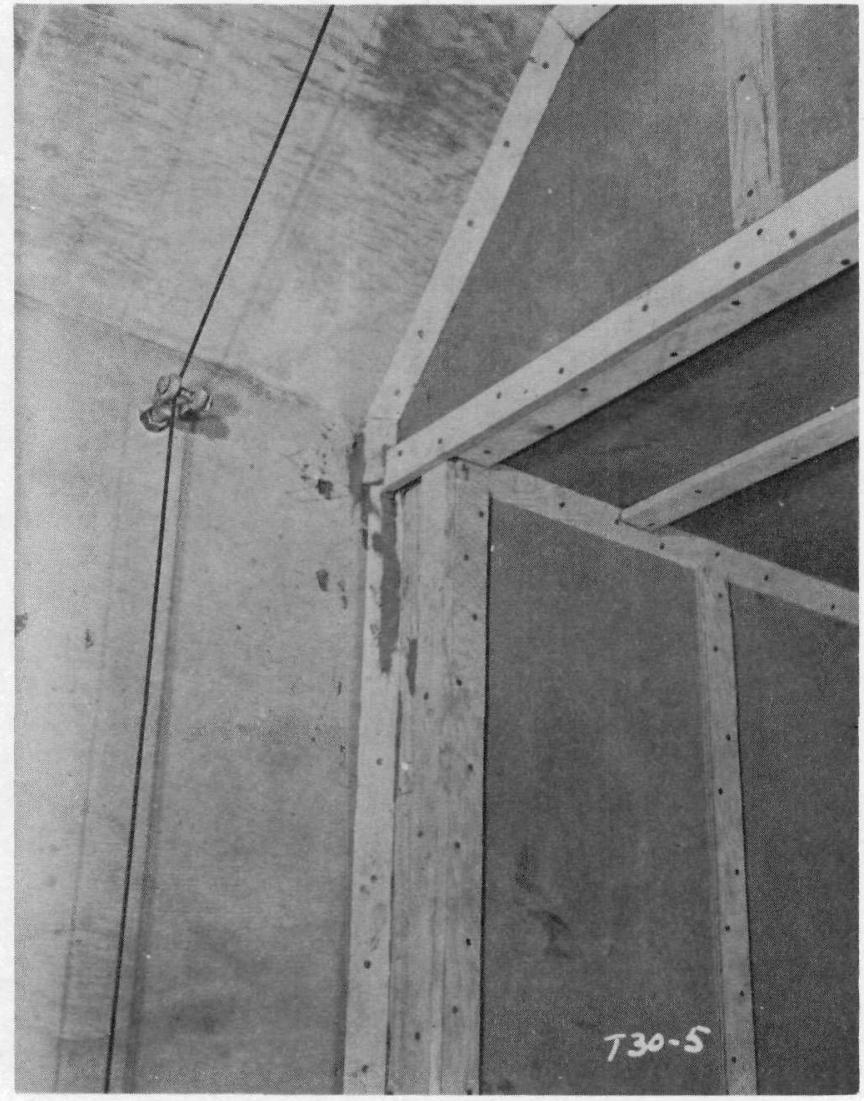

Fig. B.7-Wall seals around escape hatch.

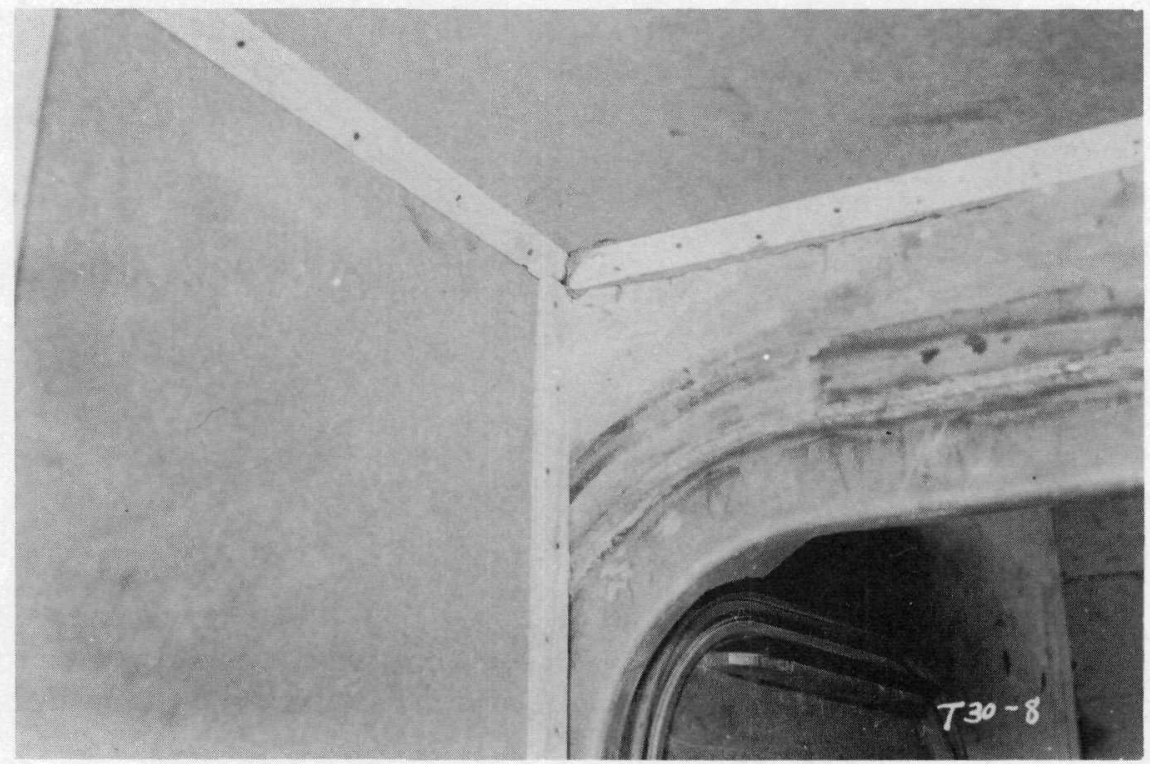

Fig. B.8 - Completed installation around entrance door. 


\section{0}

section of diffusion board mounted on the face and a wood back section fitted with two pipe nipples - one for the introduction of compressed air and the second for use as a pressure tap connected to a mercury manometer. By increasing the llow of compressed air into the plenum between the diffusion board and wood sections, the pressure was increased until rupture occurred.

From these tests it was shown that the bursting pressure of the diffusion board varies with the distance between supports. It was also shown that the use of wood cover strips in mounting the diffusion board tends to distribute the pressure along each seam and prevents the board pulling loose at the nail locations.

Further tests showed that with an even shorter span of diffusion board a somewhat higher bursting pressure could be realized, but it was felt that the additional framing required, plus the further loss of effective diffusion-board area (area made unusable because of impermeable wood backing), would make such a design undesirable.

On the basis of the foregoing tests, the diffusion board in the shelter installation was supported throughout on 2-ft centers in each direction, and a wood cover strip was used to hold the diffusion board to each of these supports. All the wood framing on which the diffusion board was mounted was of $2-$ by 2 -in. and 2 - by 4 -in. common softwood lumber. The 2- by 4 -in. framing which formed a room within the shelter was attached to the concrete walls by gundriven nail type anchors. Special care was taken in the mounting of the diffusion board. At each seam a bead of caulking material (Rhino Brand, Pecora Paint Co., Inc., Philadelphia, Pa.) was applied to each diffusion board, and a second bead was applied on top of the joint prior to installation of the cover strip. Similar care was taken where the void area was terminated, with caulking seals between the wood framing and the cement walls of the shelter. Approximately 23 quarts of caulking compounds was used to make all seams and joints impermeable.

(c) Area of Diffusion Board Available. It had been determined by previous human occupancy tests conducted at the Army Chemical Center that an area of diffusion board equivalent to $10 \mathrm{sq} \mathrm{ft}$ per man would provide satisfactory protection and environmental conditions to susstain life. In the FCDA shelter, Station 1, the available area of diffusion board was about $431 \mathrm{sq} \mathrm{ft}$. The available areas in different sections of the shelter are indicated in Table B.1. This area of diffusion board would be sufficient for 43 occupants, reducing the design occupancy from 50 .

Table B.1-AVAILABLE AREAS OF DIFFUSION BOARD

\begin{tabular}{lr}
\multicolumn{1}{c}{ Location } & $\begin{array}{c}\text { Diffusion board available, } \\
\text { sq } \mathrm{ft}\end{array}$ \\
\hline Ceiling & 198.0 \\
Front wall & 19.8 \\
Left wall & 102.3 \\
Right wall & 75.8 \\
Rear wall & 28.7 \\
Escape-hatch perimeter wall & 6.6 \\
& Total area \\
& 431.2 \\
\hline
\end{tabular}

(d) Available Void Area. The void area is important as a means of removing the carbon dioxide and water vapor passing through the diffusion board, and it acts as an expansion chamber to dissipate the pressure which passes through each of the two antiblast closures during the overpressure-initiated closing action of the closure units. In the 50-man FCDA shelter containing the diffusion-board installation, the total void area was approximately $506 \mathrm{cu} \mathrm{ft}$. A more detailed breakdown is shown in Table B.2. 


\begin{tabular}{lr}
\hline \multicolumn{1}{c}{ Location } & $\begin{array}{c}\text { Volume of void, } \\
\mathrm{cu} \mathrm{ft}\end{array}$ \\
\hline Ceiling & 249.4 \\
Front wall (including closet) & 146.3 \\
Right wall & 26.4 \\
Rear wall (including closet) & 37.9 \\
Left wall & 45.1 \\
& Total \\
\hline
\end{tabular}

(e) Antiblast Closure Settings. The $\mathrm{E}_{4}$ antiblast closure is a blast-initiated device designed to protect ventilation systems against the extreme overpressures of an atomic detonation. The unit has flanges for interconnection with standard 6-in. pipe fittings at the inlet and with standard 5-in. pipe fittings on the protected side. At a flow of $300 \mathrm{cfm}$ the air resistance of the unit is about 1 in. of water. A $1 / 8$-in.-thick $10 \% / 8$-in.-diameter aluminum plate is maintained at a height of about 1 in. above a gasketed perforated steel bedplate by a spring operating on a plunger attached to the plate at its center. In normal position the air moves around the aluminum plate and passes through the perforated bedplate. A sharp rise in overpressure forces the floating aluminum plate down on the gasketed bedplate, sealing off the unit to further air flow. This situation is relieved by the passage of the positive-pressure phase, and the unit reopens in the negative-pressure phase.

Since the shelters were designed to withstand $100 \mathrm{psi}$, a reflected pressure on the aluminum plate could be of the order of $480 \mathrm{psi}$. Assuming an instantaneous pressure rise of this magnitude, it can be shown by calculation that the closing time would be considerably less than $1 \mathrm{msec}$. However, even with such a finite closing time some of the air bypasses the valve during its closing operation.

At Aberdeen Proving Ground, shock-tube tests were conducted with the protected side of the closure connected to a sealed steel tank of known volume. This system was subjected to shock waves of varying magnitude, and pressure measurements were taken on the unprotected side of the closure and within the steel tank. On the assumption of adiabatic expansion without change in temperature, a formula was developed whereby the volume of air passing through the closure for any magnitude of overpressure could be determined if the protected side pressure and volume were known. For a given overpressure and known volume of air passing the closure, the pressure build-up in any chamber of known volume could be readily calculated. This derivation is shown in Greenhouse Annex 6.10, WT-42.

In this installation the available free void volume on the protected side of the two closures was $505 \mathrm{cu} \mathrm{ft}$, or $252.5 \mathrm{cu} \mathrm{ft}$ per closure. Using this free volume and based on a design overpressure of $100 \mathrm{psi}$, it was calculated that the pressure build-up within the void volume would be about $1 / 2 \mathrm{lb} / \mathrm{sq}$ in., assuming an immediate distribution and equilization of the pressure in all sections of the void volume. These pressure calculations were based on operation of the closure plate at a height of $1 \mathrm{in}$. above the perforated bedplate. The closets housing the intake and exhaust antiblast closures were covered with $5 / 8$-in. plywood to take care of any surge pres-sures which might momentarily develop prior to equilization of the pressure throughout the void space.

(f) Adjustment of Air Flow Through the Void. By use of the orifice installed between the pipe flanges upstream of the blower and the flow control valve located in the sheet-metal housing containing the Dustop filters, the flow through the blower was measured at $54 \mathrm{cfm}$. The flow control valve plate, which is held in position by springs, acts as a shock absorber for the high momentary flow which it is anticipated will pass the closure during its operation. 


\section{0}

(g) Shelter Aerosol Test. The principal objective of the aerosol tests conducted before and after the test detonation was to assess any change in the protective efficiency of the diffusion-board installation due to the effects of the blast. The predetonation fluorescein aerosol test was conducted by generating an aerosol concentration within the nonprotected void space and measuring the aerosol penetration at a series of sampling stations distributed throughout the protected areas of the shelter. The test data thus obtained showed a uniformly low penetration at all of the protected area sampling stations and further indicated that there were no localized sources of high leakage in the diffusion-board installation.

(h) Pressure Instrumentation. Pressure instrumentation stations were used at three locations in the shelter. The first was located outside the Navy type bulkhead door; the second was located in the void area between the masonry wall and the diffusion-board installation in the closet housing the motor blower unit; and the third pressure gauge was located in the shelter proper underneath the escape hatch. Calibration of the gauge and pressure measurements were conducted by the Sandia Corporation.

\section{B.1.4 Preshot Development Work (Pressurized Type of Shelter)}

(a) General. The 50-man shelter tested in the open shot was similar to that used for the diffusion type shelter. However, in this installation the escape hatch was located in the ceiling where the left wall (wall nearest GZ) intersected the front wall of the shelter. An exterior view of the shelter showing the blast door, escape hatch, and inlet and exhaust pipe tees is shown in Fig. B.9. In addition, an 8-in. reinforced-concrete wall was installed $4 \mathrm{ft}$ from the rear shelter wall. The room thus formed was further subdivided into two rooms of equal size by an additional concrete wall of similar thickness. The room on the right (when facing the installation from the shelter entrance door) contained the antiblast closures, inlet piping, and the motor blower and filter installation, as well as ducting through the wall to supply filtered air to the shelter proper. The left equipment room or air exhaust chamber contained the exhaust antiblast closures and piping, and two $E_{1} R_{6}$ anti-back draft valves set in the forward wall for shelter pressure regulation (Fig. B.10). In addition, this room contained a 110 -volt a-c 3-kw Onan gasoline-powered electric generator to provide a continuous power supply in the event of a power failure from the normal source, which was an Onan 5-kw generator installed outside the shelter. This equipment is shown in Fig. B.11. A Navy type steel bulkhead door was used as the entrance to the left equipment room. This door is shown in Fig. B.12. Entrance to the right equipment room could be made only by entering the left equipment room and removing a wood panel (Fig. B.13) in the partition between the two rooms. The equipment in the inlet air chamber and a general layout of the pressurized shelter are shown in Figs. B.14 and B.15, respectively.

(b) Basis of Design. The design was advantageous in that the concrete wall would provide good shielding for the occupants from any accumulation of radioactive particulate matter in the filter equipment located in the right equipment room. In addition, each of these rooms contained a gross volume of $182 \mathrm{cu} \mathrm{ft}$ which would be available for alleviation of the pressure due to the air bypassing the antiblast closures during the passage of the positive pressure wave of the detonation.

Since all the filtered air leaving the shelter would be through the left equipment room, this room was a good location for the emergency power supply. This location would provide adequate blast protection for the generator, and the hazard of a carbon monoxide build-up from exhaust would be minimized by the mixing action with the filtered air supply and the immediate exhaust of the mixture from the room through the air exhaust piping. Although not planned as a part of this test installation, it was felt that this room would be a good location for the installation of a chemical type toilet for the use of the shelter occupants.

The Chemical Corps filter used was the $E_{25}$ gas and particulate filter, $600 \mathrm{cfm}$, and at this rated flow it provides protection equivalent to that of the standard military gas mask canister. This air flow by standard ventilation practices would provide satisfactory ventilation for 60 persons. The filter unit was equipped with plywood plenums at both inlet and exhaust ends. The 


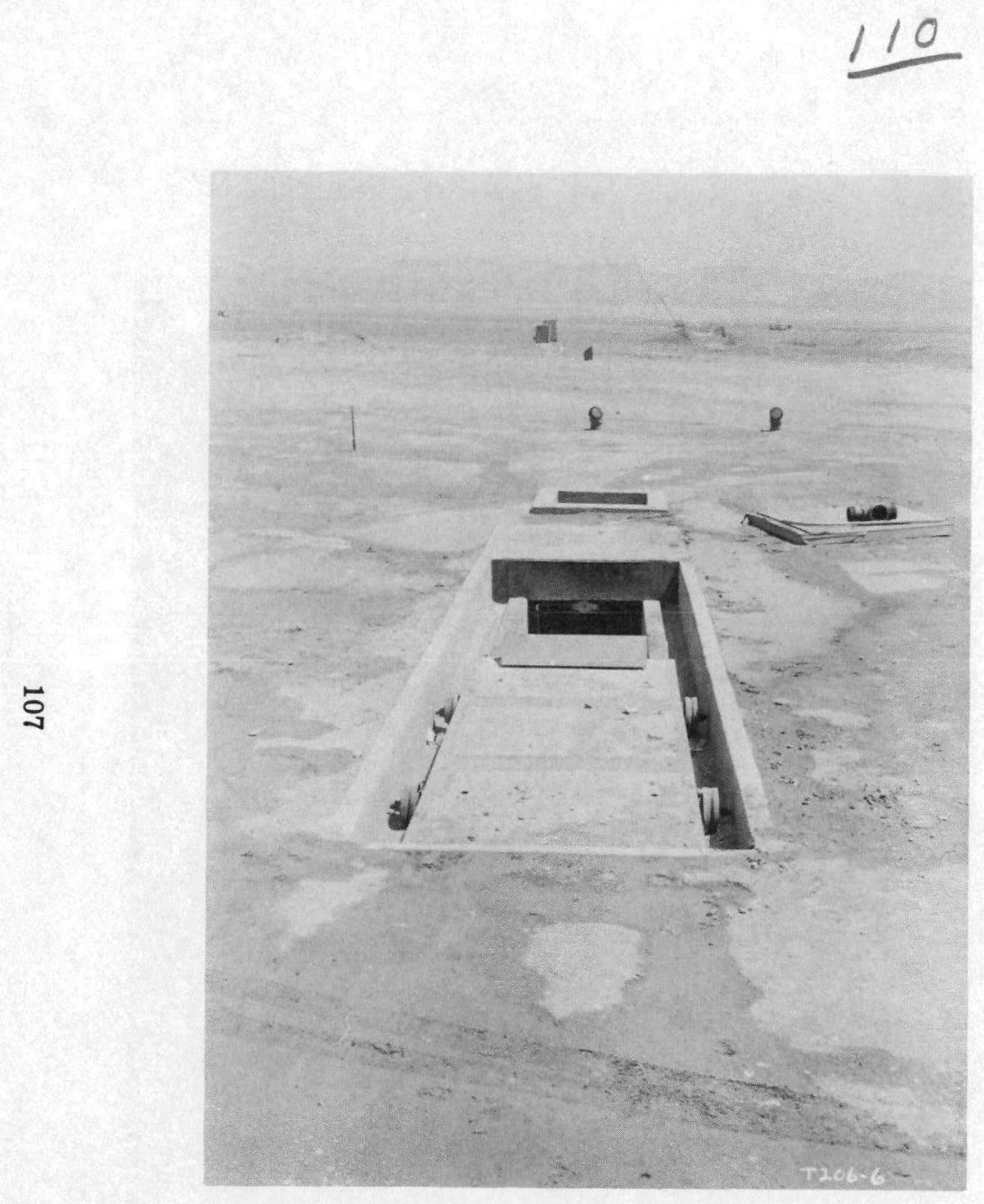

Fig. B.9-Exterior view of underground personnel shelter.

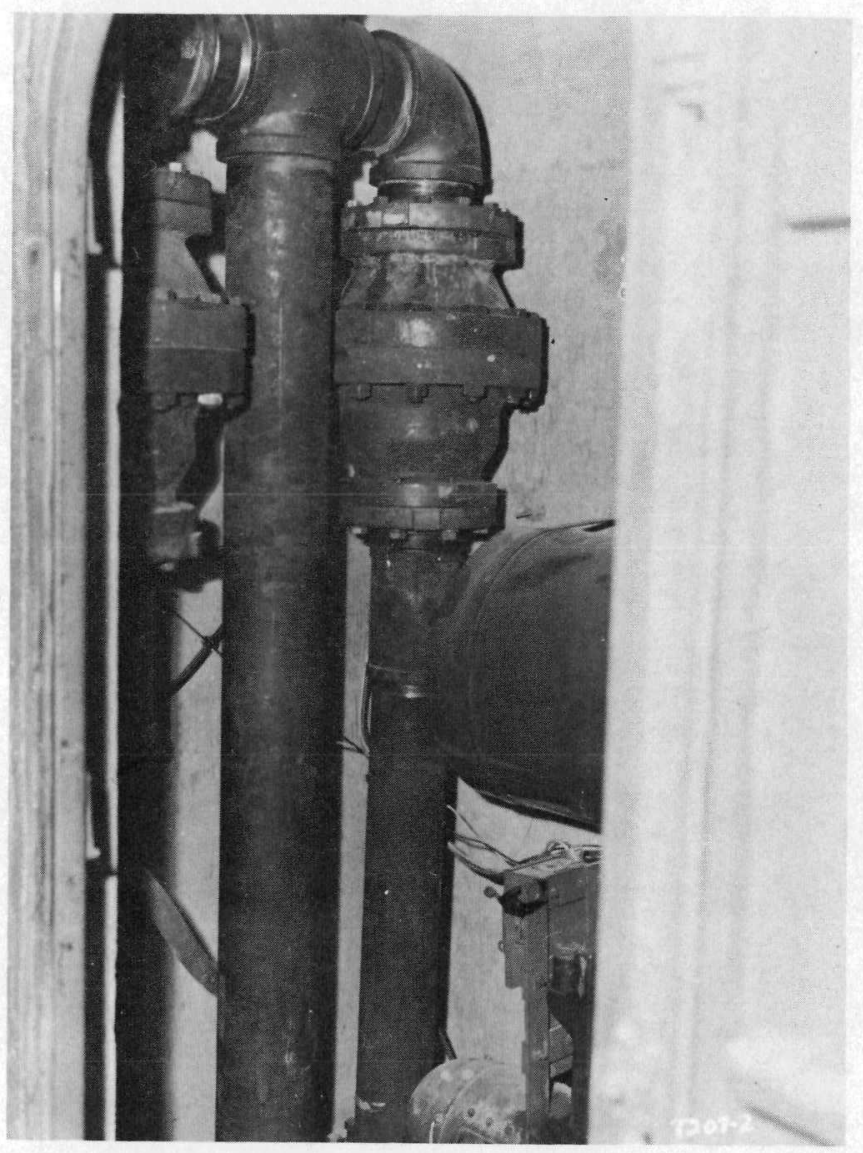

Fig. B.10 - Air exhaust chamber. 

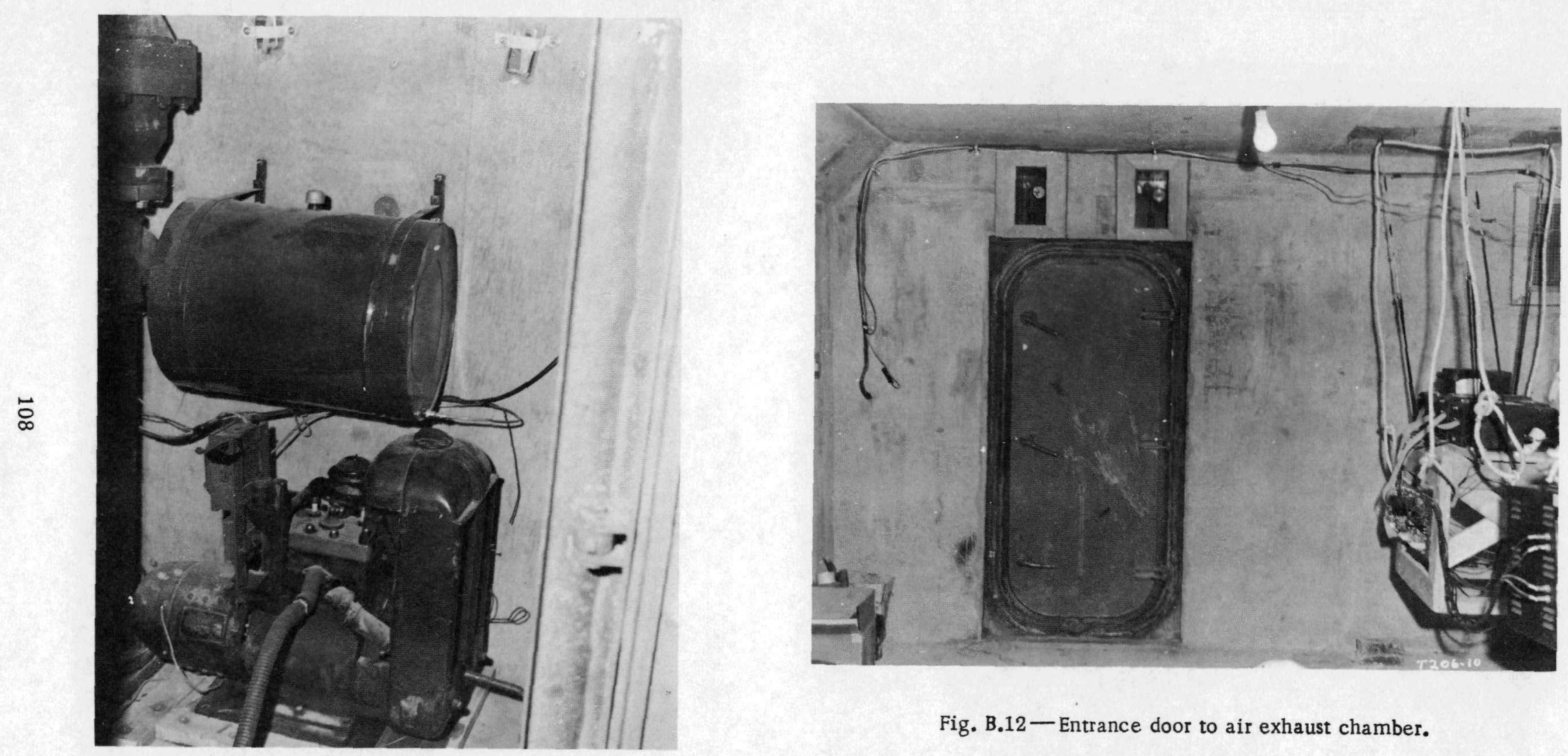

Fig. B.12-Entrance door to air exhaust chamber.

Fig. B.11-Motor generator in air exhaust chamber. 


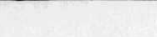




\section{2}

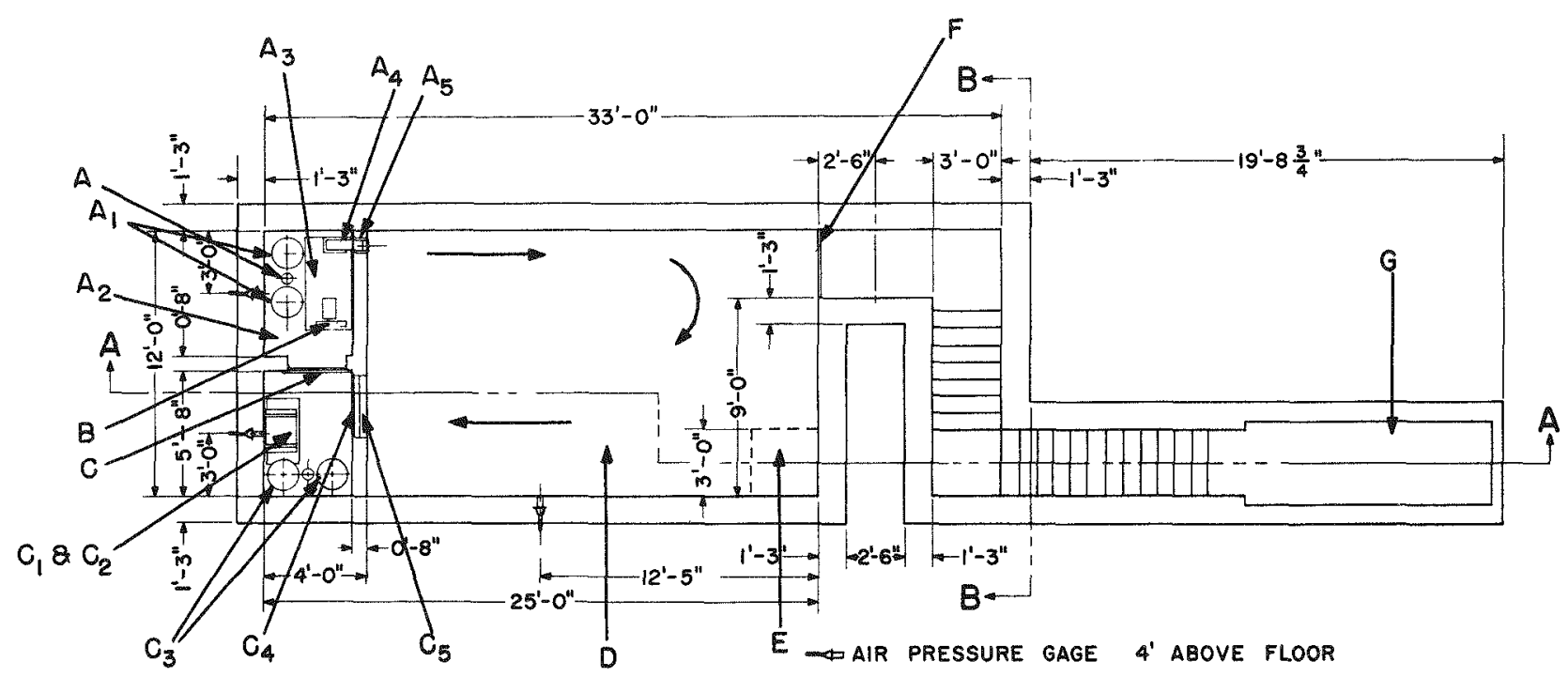

\section{LEGEND:}

A INLET AIR CHAMBER

$A_{1} E_{4}$ ANTIBLAST CLOSURES

$A_{2}$ MOTOR BLOWER UNIT

$A_{3} E_{25}$ GAS AND PARTIGULATE FILTER

$A_{4}$ ELBOW

$A_{5}$ FILTERED AIR DISCHARGE REGISTER

B WOODEN DOOR BETWEEN CHAMBERS

C EXHAUST AIR CHAMBER

$\mathrm{C}_{1} \& \mathrm{C}_{2}$ EMERGENCY POWER GENERATOR

$C_{3} E_{4}$ ANTIBLAST CLOSURES
$C_{4} \quad E_{1} R_{6}$ ANTI-BACKORAFT VALVES

$C_{5}$ NAVY-TYPE STEEL DOOR

D SHELTER PROPER

E ESCAPE HATCH

F NAVY-TYPE STEEL DOOR

$G$ CONCRETE SLAB BLAST DOOR

Fig. B.1E - Layout of pressurized shelter. 
inlet plenum was further equipped with a replaceable Dustop type prefilter to prolong the life of the main filter unit. This plenum arrangement permitted the installation of the motor blower unit and exhaust elbow on top of the filter unit, minimizing the floor space requirement for the filter installation. Two $\mathbf{E}_{4}$ antiblast closures were installed in parallel in both the inlet and exhaust piping systems to accommodate the full rated air flow of the filter unit.

(c) Inlet and Exhaust Piping Systems. Both the inlet and exhaust piping installations were identical. In each, at the top was a standard threaded 6 -in. pipe tee extending about $1 \frac{1}{2} \mathrm{ft}$ above the dirt fill. The 6-in. pipe running down through the roof of the shelter contained a pipe coupling surrounded by a concrete pier 2 by 3 by $3 \mathrm{ft}$ for anchorage and support. Near the ceiling in each installation, a set of 6 -in. threaded flanges was used to permit the uncoupling of the entire piping system within the structure if necessary.

A short distance beneath the flange installation a pipe tee was installed, the bottom connection of which was connected to a section of pipe extending down to the concrete floor with a flange at the base providing anchorage and support for the whole assembly. The two side connections of the pipe tee were connected by right-angle ells and pipe nipples to an antiblast closure located on each side of the central support pipe.

Standard 5-in. pipe tees were installed beneath each antiblast closure with the $90^{\circ}$ connection used to permit air flow and for ready access to the base of the antiblast closure spindle for a periodic inspection of the free operation of the spindle and plate assembly. Flanges whose height above the floor was adjustable were attached at the base of the pipe section connected to the tees to facilitate removal of the antiblast closures. This arrangement was common in both inlet and exhaust piping installations. The aluminum plates of all antiblast closures were set at a level of $1 \mathrm{in}$. above the gasketed bedplate.

(d) Motor Blower for $E_{25}$ Filter Unit. A blower capable of producing an air flow of $600 \mathrm{cfm}$ at an operating head of $5 \frac{1}{2}$ in. of water was procured from Revcor, Chicago, Ill. The unit had a $91 / 8$-in.-diameter impeller and would meet the flow and operating requirements; however, the 115-volt a-c 1-hp 3450-rpm electric motor used was definitely overloaded in producing this air flow at the specified operating head.

A test was conducted with the blower producing a flow of about $540 \mathrm{cfm}$ at a head of 5.8 in. of water continuously for a period of $6 \mathrm{hr}$. In this test the rise in motor temperature stabilized at about $25^{\circ} \mathrm{C}$, which was considerably less than the $40^{\circ} \mathrm{C}$ rise allowed by the manufacturer of this motor. From this test it appeared that the motor could run continuously under these conditions without undue overheating.

This flow output would be more than sufficient for a shelter of this type since with reduction in floor space due to the equipment rooms the shelter proper has $243 \mathrm{sq} f t$ of floor space and could accommodate only 40 persons on the basis of $6 \mathrm{sq} f \mathrm{ft}$ per person. According to ASHVE Ventilation Standards, $10 \mathrm{cu} \mathrm{ft}$ per person is an acceptable minimum ventilation rate.

(e) Predetonation Aerosol Tests of Filter. The major potential source of blast damage to the $\mathbb{E}_{25}$ gas and particulate filter in the pressurized structure lay in the possibility of rupture of the filter material. As indicated in Greenhouse Annex 6.10, WT-42, a classified report, rupture of particulate filters utilizing type 6 filter material occurs at relatively low pressure drops across the filter material.

In order to determine any change in filtration efficiency due to blast damage to the filter unit, aerosol tests of the filter unit were conducted "before" and "after" the test detonation. The predetonation aerosol test of this filter was conducted at the Army Chemical Center in accordance with standard Chemical Corps acceptance test procedure. The data obtained through this test indicated a satisfactorily low level of penetration which readily met current acceptance standards established by the Chemical Corps for this type of filter. A predetonation fluorescein aerosol test was also conducted on the filter unit in the shelter prior to the test detonation.

(f) Power Supply Circuit. Electrical power was supplied to the shelter from an externally installed gasoline-operated electric generator whose power supply could not be guaranteed after time zero. The emergency electrical power supply (a 115-volt a-c $3-\mathrm{kw}$ gasoline-op- 


\section{5}

erated electric generator) was provided to sustain the power supply after the detonation. This generator would operate continuously and, upon failure of the external power supply, would assume the electrical load.

To provide an automatic switchover to this power source upon failure of the external power supply, a Struthers Dunn 30-amp double-pole double-throw relay was used. This relay was wired so that as long as the solenoid was activated from the external power supply the power from this circuit would be maintained. Failure of the external power supply would deactivate the solenoid, breaking this circuit, and the spring action of the relay would close the emergency power supply circuit.

An Esterline-Angus recorder whose paper feed is powered by a 115-volt a-c synchronous electric motor was used to obtain a permanent record of how long power remained available from the outside power source and from the emergency generator. The paper feed rate was set at $6 \mathrm{in} . / \mathrm{hr}$. The pen circuits of the recorder were wired with single-pole single-throw relays so that failure of each power source would change the pen setting and the time of failure could be established from the chart. The wiring diagram is shown in Fig. B.16.

(g) Predicted Pressure Build-up in Inlet and Exhaust Air Chambers. The calculated free volume in the inlet air chamber was determined to be $160.35 \mathrm{cu} f t$ and that of the exhaust chamber, $161.18 \mathrm{cu} \mathrm{ft}$. The anticipated peak overpressure was $100 \mathrm{psi}$. However, two $\mathrm{E}_{4}$ antiblast closure units were located in each of these chambers; thus for calculation purposes it was assumed that each blast closure would have a free volume of $80 \mathrm{cu} f \mathrm{ft}$. By the method used in Sec. B.1.3e of this report, and based on the 100-psi overpressure, a peak pressure of 1.4 psi was anticipated in each of these chambers. This pressure was substantially less than the rupturing pressure for the filter material, and it was felt that subsequent reexpansion into the $1930 \mathrm{cu} \mathrm{ft}$ free volume in the shelter proper would reduce the pressure in this area to a negligible level. The antiblast closure plate settings on all valves were at a height of $1 \mathrm{in}$. above the gasketed bedplate.

(h) First Operational Tests on Shelter. The wooden door was installed between the inlet and exhaust chambers, and the crack around the edges of the door was taped with masking tape. All shelter doors were closed, including the escape hatch which was sealed with masking tape in lieu of the dirt fill normally used. Using the pressure taps at the influent and effluent ends of the filter to obtain the pressure drop across the filter, an air flow could be ascertained from previous air flow vs pressure drop taken on this filter at the Army Chemical Center.

The shelter pressure was measured by means of a draft gauge, the high pressure side of which was open in the shelter, with the low pressure side referenced to atmospheric air. In this manner the level of shelter pressure for a known input air flow could be established. The two $E_{1} R_{8}$ anti-back draft valves through which the shelter air is conducted into the exhaust chamber act to stabilize the shelter pressure; and, through the use of known counterweight settings and fixed flap openings, the volumetric air flow could be determined from predetermined calibration data.

The first series of data taken of shelter pressures at various rates of input air flow was subsequently found to be erroneous because of the leakage of air around the wooden door installed between the inlet and exhaust air chambers. Since the recirculated air would not contribute to the shelter pressurization level and only a total flow measurement through the filter was obta ined, the relative amounts of fresh and recirculated air could not readily be established.

The leakage was discovered during subsequent tests in which the gasoline-powered electric generator was operated in the exhaust chamber, with the filtered air supply on and all doors closed. In these tests, after 20 min of operation, the carbon monoxide content of the shelter was found to be 0.04 per cent, using a Mine Safety Appliance Co. carbon monoxide detector. It was felt at the time that this carbon monoxide level could have resulted from initial leakage in setting up this test, and under these conditions the continuous input of fresh air would act to dilute and reduce the carbon monoxide content in the shelter. However, at the end of $1 \mathrm{hr}$ the carbon monoxide content in the filtered air supply to the shelter proper was measured and determined to be 0.04 per cent, firmly establishing that there was leakage between the exhaust and inlet air chambers. 


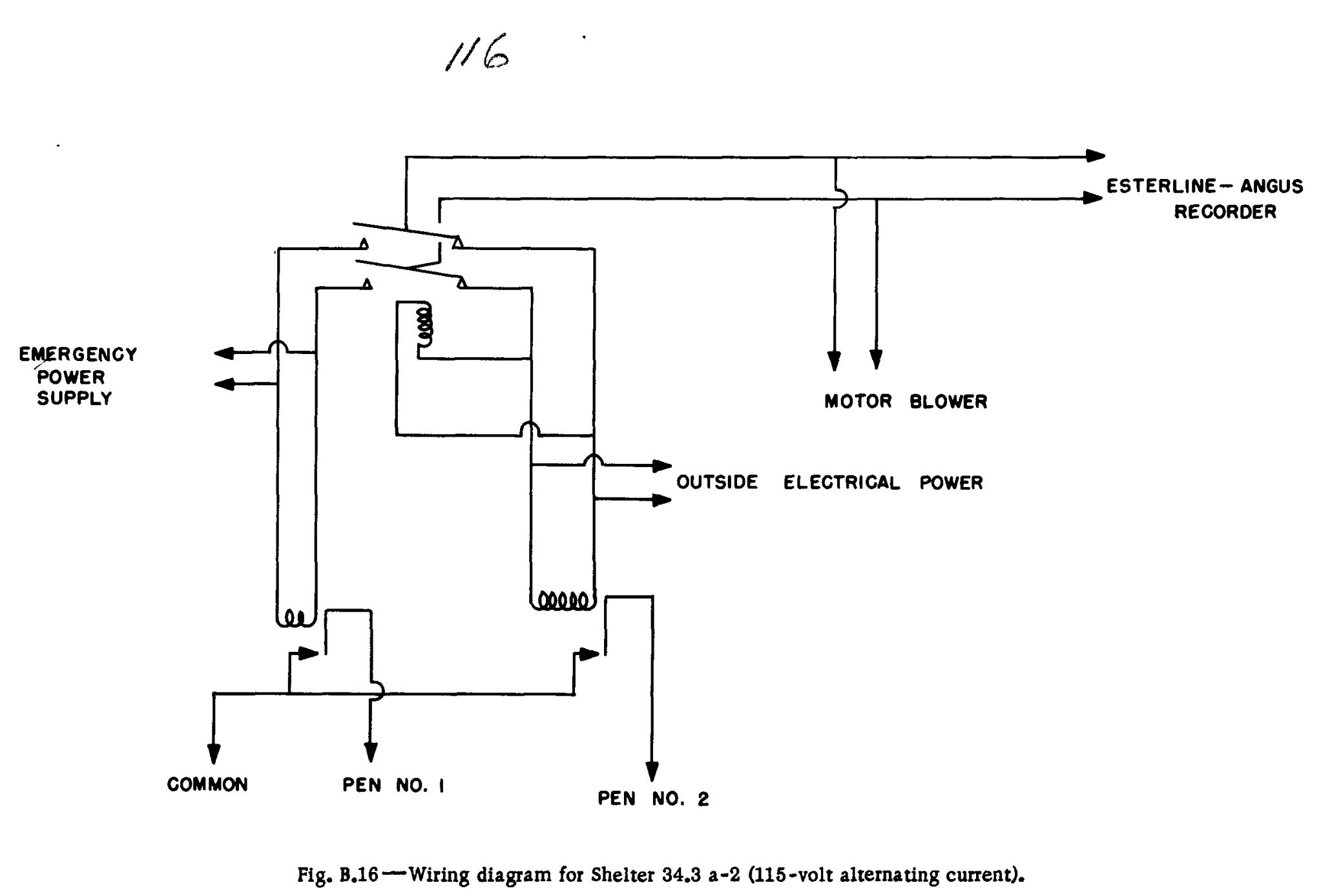


It was also noted that the temperature in the exhaust chamber where the gasoline-powered electric generator was operated rose only to $80^{\circ} \mathrm{F}$ during the test, which indicated that the air supply through the exhaust chamber was adequate for ventilation of the gasoline-powered electric generator.

(i) Final Operational Tests on Shelter. To eliminate leakage around the wooden door separating the inlet and exhaust air chambers, a commercial caulking compound was used to seal the crack around the perimeter of the door; the caulked area was covered with masking tape; and the three wooden bars holding the door in place were tightened with wooden wedges to further improve the seal. With the improved door seal, the operational test of the shelter was reinitiated with the gasoline-operated generator with the filtered air supply on and with all shelter doors closed.

At the end of $15 \mathrm{~min}$, the carbon monoxide in the filtered air which was discharged into the shelter was measured and was found to be zero. The content in the shelter after 17 min of operation was similarly found to be zero. At a time level of $25 \mathrm{~min}$, the carbon monoxide content in the exhaust chamber where the generator was located was found to be 0.06 per cent. After $1 \mathrm{hr}$ of operation the carbon monoxide content in the filtered air discharged to the shelter and within the shelter was again determined to be zero. At this time the level in the exhaust chamber was 0.08 per cent.

During this test the shelter pressurization level was maintained at about $0.75 \mathrm{in}$. of water as referred to atmosphere. The counterweight settings on the two $E_{1} R_{6}$ anti-back draft valves located in the wall between the shelter proper and the exhaust chamber were $2 \% 8$ in. on valve 1 and $2 \frac{1}{8}$ in. on valve 2 . The combined flow through the valves was about $250 \mathrm{cfm}$. For the last $10 \mathrm{~min}$ of this test, the main electrical power source was cut off, and the system reverted to operation on the emergency electrical power generator. This power source assumed the electrical load without difficulty and operated adequately for the $10 \mathrm{mmin}$ period. It was noted that the shelter pressure during operation on the emergency power source was about 0.1 in. of water lower than with the system operating from the outside current supply. This condition was presumably due to a lower voltage output from the emergency generator and was not deemed serious.

(j) Final Pressurization Tests of Shelter. With the wooden door between inlet and exhaust chambers caulked and sealed, access to the filter for pressure drop-air flow measurements was no longer possible without breaking the sealing on this door. This condition precluded the measurement of air flow by the pressure drop method, and, since direct flow measurement equipment was not available, an indirect method of ascertaining the air flow through the electrical power input to the motor blower unit was used in these tests.

The electrical power input to the motor blower was measured with a wattmeter (model 432, Weston Electrical Instrument Corp., Newark, N. J.). The laboratory data of flow vs power input, as shown in Fig. B.17, were used to obtain the flow measurement for measured power values at the test site. The data thus obtained, together with the flow through the anti-back draft valves and shelter leakage, are shown in Table B.3 and in Fig. B.18. During these tests all doors were closed, and the escape hatch was taped in lieu of the dirt fill normally utilized. Although the method used did not utilize a direct method of flow measurement, the data are believed to be substantially correct. As indicated in Table B.3, the flow setting to be used during the detonation was about $378 \mathrm{cfm}$ with a protective level of pressurization of $0.71 \mathrm{in}$. of water.

\section{B.2 TEST RESULTS}

\section{B.2.1 Test Results on the Diffusion Shelter}

(a) General. The 50-man shelter equipped with diffusion board was tested on early shot. There was no discernible structural damage. 


\section{$1+\&$}

Table B.3-SHELTER PRESSURIZATION DATA

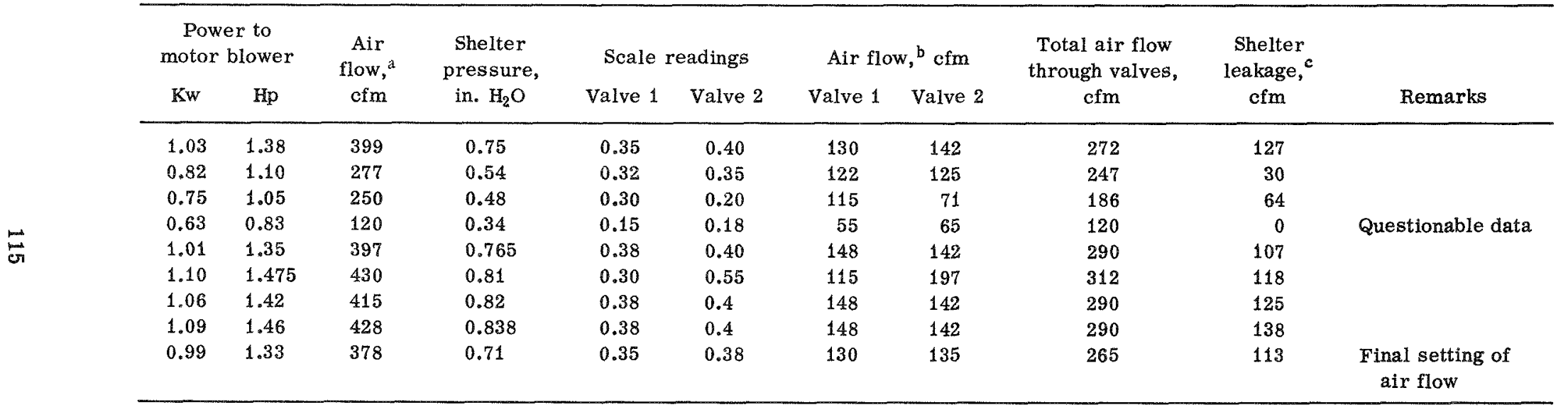

${ }^{a}$ Air flow was controlled by the adjustable louvres in air discharge register.

Obtained from $E_{1} R_{6}$ anti-back draft valve calibration data not included in this report.

${ }^{c}$ Air flow not passing through $E_{1} R_{6}$ anti-back draft valves, including the leakage of the entrance door, escape hatch, bulkhead door between shelter and exhaust air chamber, and that of the walls, floor, and ceiling of the shelter at the indicated pressure level. 


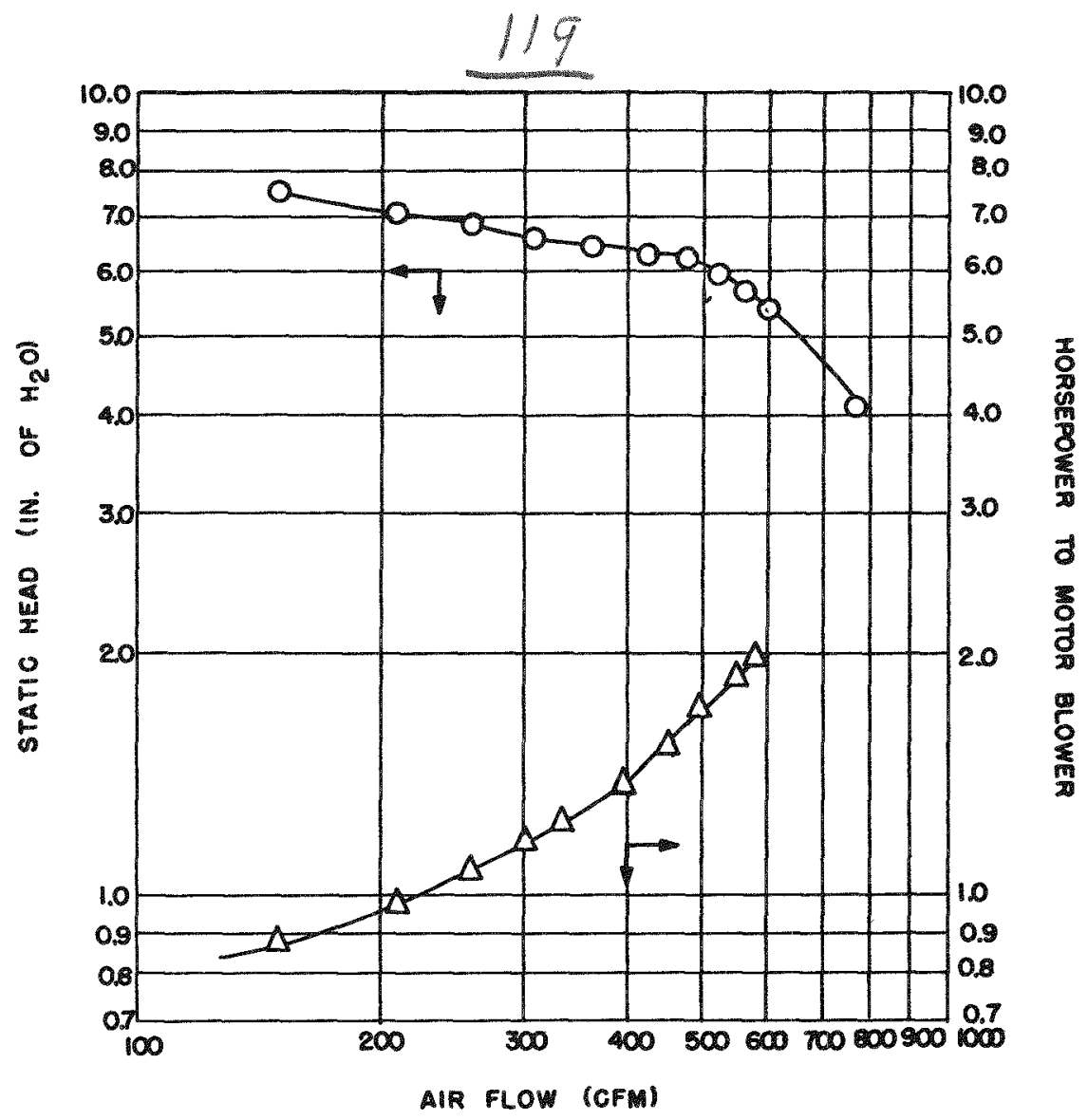

Fig. B.17-Laboratory data of flow vs power input.

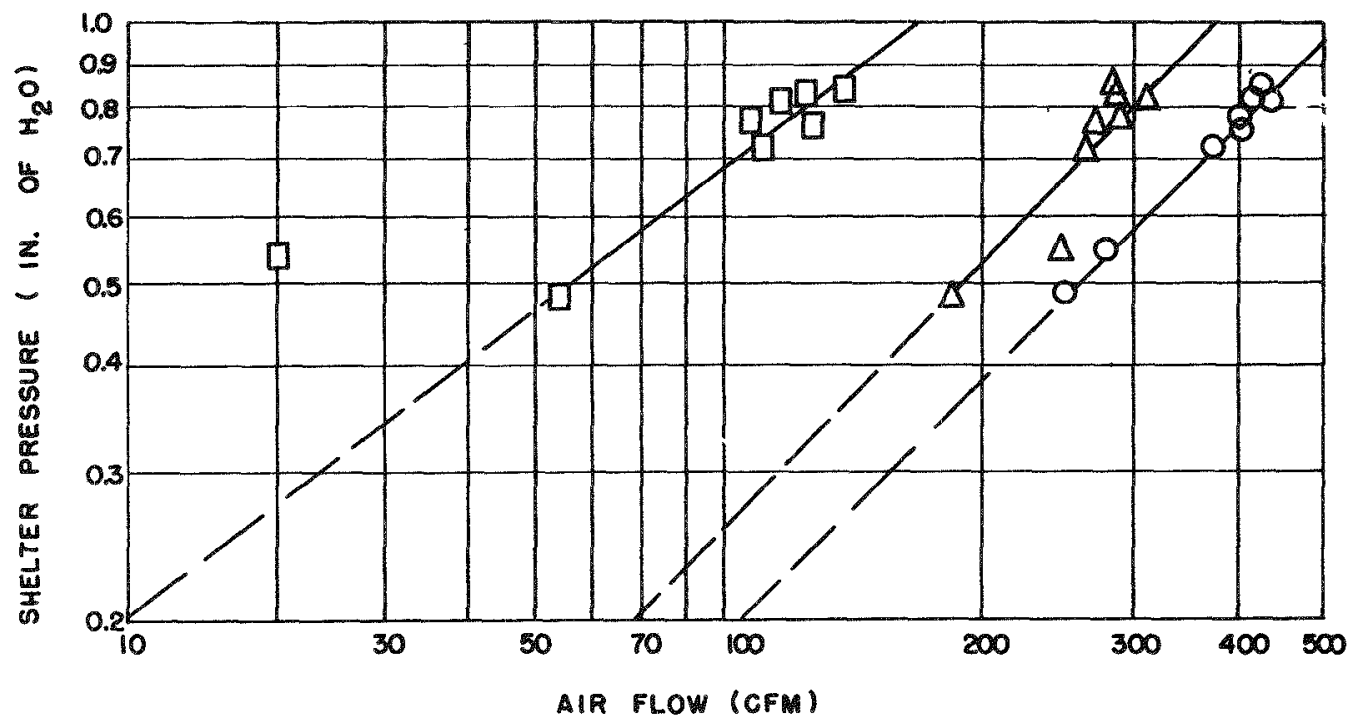

Fig, B.18-Flow measurements for measured power values compared with flow through anti-back draft valves and shelter leakage. $O$, total filtered air input.

$\Delta$, flow of air leaving shelter through valves. $\square$, shelter leakage. 
(b) Inlel and Exhaust Pipes. The inlet and exhaust pipes whose tees were about $3 \mathrm{ft}$ above the ground were bent to an angle of $60^{\circ}$ from the perpendicular, but it appeared that these pipes could still have provided the requisite ventilation for the void area between the diffusion board and the structural walls of the shelter.

(c) Diffusion-board Installation. A visual inspection of the diffusion-board installation was made, and it revealed no signs of rupture or visible damage.

(d) Pressure Within Shelter. Pressure instrumentation by the Sandia Corporation of the void area behind the diffusion-board walls and within the shelter proper indicated a zero pressure reading at each location.

(e) Electrical Power from Gasoline-powered Generator. The chart record from the Esterline-Angus recorder indicated that power was available to the motor blower unit (used for ventilation of the void area) for a period of about $2 \frac{1}{2} \mathrm{hr}$ following the test detonation. This evidence is important since it shows that a gasoline-operated electric generator of this type with both air inlet and exhaust open to blast pressures of this magnitude can provide an uninterrupted power supply throughout the detonation.

(f) Motor Blower Unit. The motor blower unit with filters used for ventilation of the void area was not visually damaged.

(g) Postshot Aerosol Test of Shelter. Three days after the shot, an aerosol test was conducted on the shelter to determine if the protective efficiency of the diffusion-board installation had been impaired by the detonation. The test procedure used was similar to that employed in the predetonation aerosol test. The penetration data obtained were again found to be uniform throughout the series of sampling stations within the protected area, and the over-all penetration value for this test was less than that measured in the predetonation aerosol test. These test results indicated that there was no adverse change in the filtration characteristics of the diffusion-board installation due to the test detonation.

\section{B.2.2 Test Results on Pressurized Shelter}

(a) General. The 50-man shelter equipped as a pressurized shelter was tested in the open shot. The peak overpressure at the shelter was very close to the 100 psi predicted. The structure was for all practical purposes undamaged by the blast.

(b) Air Inlet and Exhaust Pipe Tees. The threaded pipe tees whose open ends were oriented to $90^{\circ}$ from $\mathrm{GZ}$ and whose height above the ground was about $18 \mathrm{in}$. were torn off by the blast and blown approximately $1 / 4$ mile from the shelter location. The 6 -in. air exhaust pipe was bent about $20^{\circ}$, and the air inlet pipe was bent about $5^{\circ}$ from the perpendicular.

(c) Pressure Instrumentation in Shelter. As previously indicated, pressure instrumentation by the Sandia Corporation was at three locations in the shelter: the inlet air chamber, the exhaust air chamber, and within the shelter proper. Two of these pressure records were not usable because of malfunction. The third pressure record, which was of the inlet air chamber, showed a negligible pressure during the positive pressure wave and clearly showed the changeover to the negative or vacuum phase of the shock front. A preliminary review of this record indicated that the peak of the negative phase would be of the order of about 2 psi, which is a reasonable value for a shock wave of this magnitude. It is believed that the shelter proper was subjected to even less pressure owing to the large free volume available for alleviation of the pressure.

(d) Functioning of $E_{4}$ Antiblast Closure Units. The $\mathrm{E}_{4}$ antiblast closure units functioned very well in reducing the overpressure to a negligible level within the shelter. The valves were checked on $D+1$ day, and each appeared to function satisfactorily; however, the valves were not disassembled at this time.

(e) Preliminary Visual Inspection of Equipment. In the D+1 entry a visual inspection of the gasoline generator, tank, anti-back draft valves, motor blower, and filter equipment was 
made. This inspection did not disclose any visual damage to any of the equipment indicated above from the effects of the blast nor were there any discernible thermal effects such as scorching of the wooden door between the inlet and exhaust air chambers. An aerosol test was used to determine whether the Chemical Corps filter was damaged or not.

(f) Power Supply. The Esterline-Angus recorder provided a permanent record of how long the power supply was available from the outside and inside gasoline-operated electric generator units. This chart indicated that the outside power source failed at 0448 and the inside generator power failed at 0452. The time of the detonation was 0510 .

(g) Postdelonation Aerosol Tests of Filter. The postdetonation fluorescein aerosol test showed a slightly higher penetration than that indicated in the predetonation test. This increase, however, was not deemed significant. Following Operation Teapot, the $\mathbf{E}_{25}$ gas and particulate filter was returned to the Army Chemical Centex for a more precise assessment of postshot filtration characteristics under laboratory conditions. The aerosol test procedure previously employed for the predetonation aerosol test was again utilized. The average penetration value for the filter as shown by the postshot aerosol test at Army Chemical Center was slightly lower than that which was obtained in the predetonation aerosol test. These data provide positive evidence that there was no reduction in the filtration characteristics of the unit caused by the test detonation.

\section{B. 3 DISCUSSION}

\section{B.3.1 Diffusion Shelter}

(a) Aerosol Tests of Diffusion Type Shelter. An analysis of the "before" and "after" aerosol penetration test data on the diffusion type shelter indicated that the measured penetration following the test detonation was lower than that obtained in the predetonation test. This increase in filtration is caused by a plugging action which takes place in any mechanical filter used against solid aerosols. In this process both the resistance to air flow and the filtration of aerosol matter will increase. The principal information gained from these tests, however, was that the filtration characteristics of the diffusion-board installation were not impaired by the effects of the blast.

(b) Antiblast Closure Operation. The $\mathrm{E}_{4}$ antiblast closures performed well in the protection of the diffusion-board installation. Static pressure tests indicated that a pressure of 1 psi would produce rupture of the board. With the peak overpressure of the early shot, the diffusion-board installation was not visually damaged, and aerosol tests confirmed that the filtration property of the installation was not imparied by the blast. Pressure gauges both in the void and in the shelter proper showed zero pressure readings.

(c) Diffusion-board Installation. The principal objective of this test work was to determine whether a diffusion-board installation of this type could be adequately protected from the effects of blast. From the test results this condition was met. However, even with the extreme care utilized in the construction of the diffusion-board installation, there was some leakage of the installation as indicated by the aerosol tests. This condition points up the requirement for additional development work on sealing methods and for improved test methods for locating any minor sources of leakage in an installation of this type.

(d) Ventilation of the Void Area. Details of the film dosimeter data are presented in Chap. 2, Tables 2.2 through 2.12 .

In an underground shelter of this type, ventilation of the void area between the diffusion board and the structural walls is necessary to provide optimum conditions for the diffusion of carbon dioxide and water vapor through the diffusion board. In this shelter two Dustop filters arranged in series were used for dust filtration of the air supply in the void.

Although the film dosimeters located at the filters registered only $1.2 \mathrm{r}$ as compared to a range of 0.6 to $1.0 \mathrm{r}$ in the various film dosimeters in the shelter proper, in an area of heavy 
fall-out the activity rate would increase considerably, ana radiation shielding of the air inlet and air exhaust equipment should be incorporated in subsequent designs of shelters of this type. Similarly, consideration should be given to the use of standard Army Chemical Corps types of particulate filters for a more absolute filtration of dust and radioactive materials of various types since contamination of the void area with radioactive materials would pose a distinct radiation hazard for the occupants of the shelter.

\section{B.3.2 Pressurized Shelter}

(a) Inlet and Exhaust Pipes. The inlet and exhaust pipe tees, because of their orientation $90^{\circ}$ from $\mathrm{GZ}$, were subjected to the maximum bending and shear forces at the 1050-ft station. Although the pipe tees were torn off by the force of the blast and the pipes bent, the damage incurred would not have affected the operation of the ventilation system within the structure. The lowering of the height of the inlet tees from $36 \mathrm{in.}$ in the early shot to $18 \mathrm{in}$. in the open shot reduced the bend in the pipes from 60 to $20^{\circ}$. It is suggested in future pipe inlet configurations that these tees be welded to the pipe rather than be dependent upon the thread strength alone.

(b) Aerosol Tests and Ventilation Equipment. The slightly lower penetration measured in the postdetonation test of the filter at the Army Chemical Center was probably due to the plugging effect caused by the prior aerosol tests and the subsequent removal of particulate matter by a mechanical filter of this type in normal operation. Under these circumstances the accumulation of particulate matter tends to increase both the aerosol filtration of the filter and its pressure drop for a given air flow. It is felt that the aerosol tests of this filter show conclusively that there was no adverse effect on filtration due to the test detonation.

Based on a surveillance of the ventilation equipment, it was concluded that the $E_{4}$ antiblast closure had functioned well in preventing damage to the motor blower, the $E_{25}$ filter, the elbow and air register, and the anti-back draft valves.

(c) Power Supply. As previously indicated, the Esterline-Angus chart indicated failure of the outside power generator at 0448 and failure of the generator located in the exhaust air chamber at 0452 . From this data it would appear that both power sources failed prior to zero. However, the chart was driven by a 115 -volt 60 -cycle synchronous motor, and, owing to the relatively heavy loading on the generator circuit in supplying power for this shelter and at Station $34.3 \mathrm{a}-2$, it is possible that reduced voltage and frequency lowered the chart speed, making the power supply available through time zero. The possibility of a lowered frequency was brought about by the perceptible flicker in the light bulbs during previous dry runs. In three of these dry runs, the generator ran a number of hours after the anticipated shot time. The electrical load of the shelter equipment was only about one-half of the rated capacity of the emergency power generator. In a number of prior tests this generator had assumed this load without malfunction. With the protection of the antiblast closures, the generator was exposed to only a negligible overpressure, and, from the early shot results, the outside generator continued operation.

The assumptions that the emergency power generator operated through the blast and that failure was due to lack of oxygen on the premise the antiblast closures failed to reopen are invalid since this generator had been run for periods of about $10 \mathrm{~min}$ in previous tests without ventilation and did not malfunction. To date, no valid reason has been found for the failure of the inside generator. The amount of debris and dirt deposited in the outside generator could have caused its failure if the generator was operating at time zero.

(d) Design Changes in Emergency Power Generator Installation. Since there were no personnel in the shelter during the test detonation, in order to protect the gasoline-operated power generator in so far as possible from the effects of overpressure, the engine exhaust was allowed to discharge directly into the air in the exhaust chamber. As was shown in the operational tests of the shelter, leakage around the wood panel between the inlet and exhaust air 


$$
12 x^{2}
$$

chambers was a potential hazard because of the carbon monoxide in the generator exhaust. This leakage was subsequently eliminated by caulking and taping around the edges of the panel.

In shelters designed for actual use rather than test, the exhaust from the gasoline generator should not be discharged directly into the air in the exhaust chamber. An improved design for the engine exhaust would utilize an exhaust system constructed of standard pipe and pipe fittings. This line would run directly from the exhaust manifold of the engine to the outside atmosphere and would be equipped with a gate valve which would normally be closed as long as commercial power is available. This would prevent possible blast damage to the generator. When the commercial power supply failed because of blast, the valve could be opened and the generator started by one of the shelter occupants. The exhaust line above ground level would utilize a standard tee fitting at the discharge end of the line. In this way the generator would be protected from blast, and the hazard of carbon monoxide within the exhaust air chamber or the shelter proper would be minimized.

(e) Open Shelters Vs Closed Shelters. The effectiveness of the closed shelter can be evaluated by considering that the pressure inside would have been as high as 75 psi had the shelter been left open, against no pressure in the shelter as tested. The residual radiation would have been $14 \mathrm{r}$ as against $10 \mathrm{mr}$ in the closed shelter. Heat within $3 \mathrm{ft}$ of the entrance of the shelter would have been sufficient to cause serious burns had the shelter been left open. These comparisons are possible by the open shelter design used by Project 33.1 (reference 1).

(f) Design Changes in Chemical Corps Filter Assembly. As previously indicated in Sec. B.1.4d, the 1-hp motor coupled to the motor blower on the $\mathrm{E}_{25}$ gas and particulate filter was overloaded in producing an air flow of $600 \mathrm{cfm}$ at a static pressure of $5 \frac{1}{2} \mathrm{in}$. of water. Within the time limitations imposed by the Teapot test program, there was insufficient time to procure a more suitable electric motor. Although no operating difficulties were encountered due to overloading of the 1-hp motor during this test, it is felt that a more powerful motor should be provided for the motor blower installation if the present Revcor blower is retained in subsequent filter designs of this type.

The $\mathbf{E}_{25}$ gas and particulate filter with plenums and skid had a height of about $30 \%$ in., a width of $27 \mathrm{in.}$, and a length of $53 \frac{1}{2}$ in. The steel bulkhead door between the shelter proper and exhaust chamber has a net clearance in the width dimension of 26 in. through which the filter unit had to be moved for final installation in the inlet air chamber. In the Teapot operation the $\mathrm{E}_{25}$ filter width was reduced from 27 to $25^{1 / 2}$ in. by removing the $3 / 4$-in. plywood cover strips on each side of the filter. These strips were subsequently replaced prior to final positioning of the filter unit. If the present steel bulkhead door is retained in future shelter designs, the $3 / 4$-in. plywood cover strips on each side of the filter should be replaced with thin sheet-metal strips which will provide the necessary air seal and permit movement of the filter through the 26-in. door width without disassembly of the cover strips.

\section{B.4 CONCLUSIONS AND RECOMMENDATIONS}

\section{B.4.1 Conclusions}

(a) Diffusion Shelter. Under the loading at the shelter location, the protective characteristics of the shelter and its air filtration system were not impaired by the test detonation.

(b) Pressurized Shelter. The peak overpressure encountered during the test detonation did not adversely affect the efficiency of the protective ventilation of the pressurized shelter.

\section{B.4.2 Recommendations}

(a) Air Ducting, Diffusion, and Pressurized Shelters. Weld type pipe fittings and heavyduty pipe should be employed in the exposed duct sections above the shelter in future designs to provide increased resistance to damage by blast. 
(b) Wood Panel Between Inlet and Exhaust Chambers. Future designs should utilize gasketing together with a positive type of mechanical clamping device for the panel installation to eliminate air leakage between the inlet and exhaust chambers.

(c) Exhaust from Gasoline-powered Electric Generator, Pressurized Shelter. The exhaust from the gasoline-powered electric generator in future shelter designs should not be discharged directly into the air in the exhaust chamber but should be handled as described in Sec. B.3.2d.

(d) Design Changes in Chemical Corps Filter Assembly. (1) Motor Blower. An electrical motor of increased power should be utilized if the present Revcor blower is retained for use with the $E_{25}$ gas and particulate filter.

(2) Plywood Cover Strips on $E_{25}$ Gas and Particulate Filter. The $3 / 4$-in. plywood cover strips on the sides of the $E_{25}$ filter should be replaced with thin sheet-metal strips to permit passage through the steel bulkhead door between the shelter proper and air exhaust chamber without disassembly as explained in Sec. B.3.2f.

(e) Draft Gauge Installation, Pressurized Shelter. In future shelter designs the shelter should be equipped with a permanently installed draft gauge so that the level of the protective pressure within the structure can be readily determined at any time by the shelter occupants.

\section{REFERENCE}

1. C. S. White et al., Effect of Overpressures on Biological Systems, Operation Teapot Report, WT-1179. 